KEZER MARCUS MORAIS DE ALMEIDA

ANÁLISE DA GESTÃO DE RISCOS APLICADA NA AQUISIÇÃO DE BENS E SERVIÇOS PARA OS PROJETOS DE BENS DE CAPITAL 
KEZER MARCUS MORAIS DE ALMEIDA

\section{ANÁLISE DA GESTÃO DE RISCOS APLICADA NA AQUISIÇÃO DE BENS E SERVIÇOS PARA OS PROJETOS DE BENS DE CAPITAL}

Dissertação apresentada à Escola

Politécnica da Universidade de São Paulo para obtenção do título de Mestre em

Engenharia

Área de Concentração;

Engenharia Naval e Oceânica

Orientador:

Prof. Dr. Bernardo L. Rodrigues de Andrade 
Este exemplar foi revisado e alterado em relação à versão original, sob responsabilidade única do autor e com a anuência de seu orientador.

São Paulo, 10 de Outubro de de 2008

Assinatura do autor

Assinatura do orientador

FICHA CATALOGRÁFICA

Almeida, Kezer Marcus Morais de

Análise da gestão de riscos aplicada na aquisição de bens e serviços para os projetos de bens de capital / K.M.M. de Almeida. -São Paulo, 2008.

$164 \mathrm{p}$.

Disse rtação (Mestrado) - Escola Politécnica da Universida de de São Paulo. Departamento de Engenharia Naval e Oceânica.

1.Administração de proje tos 2.Administração de risco 3.Bens de capital (Projeto) I.Universidade de São Paulo. Escola Poli-técnica. Departamento de Engenharia Naval e Oceânica Il.t. 


\section{DEDICATÓRIA}

Dedico este trabalho a meus pais, a minha querida esposa Débora e aos meus filhos Tiago e Gabriela 


\section{AGRADECIMENTOS}

Ao meu professor e orientador Prof. Dr. Bernardo Luis Rodrigues de Andrade pela confiança, incentivo, diretrizes e sugestões para a realização deste trabalho.

As empresas pesquisadas pela disponibilidade e atenção dispensadas nas entrevistas e por demonstrarem interesse no assunto.

A minha família, pela compreensão e colaboração demonstrada nos momentos de elaboração deste trabalho. 


\section{RESUMO}

Dentre as melhores práticas de gerenciamento de projetos, que envolvem áreas de conhecimento como escopo, prazo, custos, qualidade, comunicação, recursos humanos, aquisições, segurança, meio ambiente e a integração destas disciplinas e seus processos, a gestão de riscos é uma das áreas de relevância e que tem sido estudada, detalhada e aplicada nas organizações. Porém o tema da gestão de riscos com o foco nas aquisições de bens e serviços em projetos de bens de capital embora contribua para o atendimento dos objetivos dos projetos não é comumente encontrado na literatura técnica em gerenciamento de projetos.

Este trabalho analisa especificamente a gestão dos riscos operacionais do processo de aquisição de bens e serviços para a implantação de projetos de bens de capital, compreendidos desde o processo de planejamento da aquisição até o encerramento do contrato. Através de uma revisão conceitual e da aplicação de estudos de casos em três empresas de relevância no cenário de negócios e de projetos no nível nacional e internacional foi possível validar a importância do tema no contexto de projetos de bens de capital, bem como compreender como as empresas pesquisadas estão estruturadas para o gerenciamento de riscos, relacionar categorias típicas de riscos para a aquisição de bens e serviços nestes projetos, verificar a aderência aos conceitos teóricos e identificar algumas práticas consolidadas e não consolidadas sobre o assunto baseado na análise de dados e lições aprendidas das empresas pesquisadas.

Palavras-chave: Gerenciamento de Riscos. Gerenciamento de Projetos. Gerenciamento das Aquisições. Administração de Contratos. 


\begin{abstract}
Considering all project management best practices, who involve process groups as scope, time, costs, quality, communication, human resources, procurement, safety, environment and the integration of all of them and its processes, the risk management is one of the relevant areas who has been studied, detailed and applied in some organizations. However the risk management focus on procurement and contracts even contributing with the success of the project's objectives it is not a common subject found at project management technical literature.

This research focus specifically at the capital project risk management for the procurement of goods and contracts, from the procurement and contract planning phase till the contract close out. The research was conducted through a conceptual review and the application of case studies in three relevant organizations regarding their business and projects from the Brazilian and international scenarios. As a result it was possible to validate the importance of the procurement and contracts risk management for the capital projects, as well to understand how the studied organizations are structured to deal with the risk management, to list the typical risk categories, to verify the conceptual adherence and finally to identify the consolidated and non consolidated practices based on the data analysis from the studied organizations.
\end{abstract}

Keywords: Risk Management. Project Management. Procurement Management. Contract Management. 


\section{LISTA DE ILUSTRAÇÕES}

Figura 1 - Índice de sucesso dos projetos ………............................................. 16

Figura 2 - Ciclo de Vida Típico dos projetos de bens de capital ........................... 18

Figura 3 - Classificação das organizações relativas ao gerenciamento de projetos. 27

Figura 4 - Áreas de especialização do gerenciamento de projetos ........................29

Figura 5 - Benefícios do gerenciamento de projetos ..........................................30

Figura 6 - Áreas de conhecimento e grupos de processo do PMBOK .....................31

Figura 7 - Processos de gerenciamento de projetos do PMBOK ……....................32

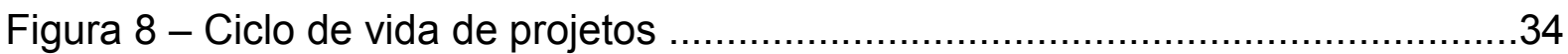

Figura 9 - Influência e investimentos $x$ fase do projeto ………............................35

Figura 10 - Riscos internos e externos dos projetos ..........................................

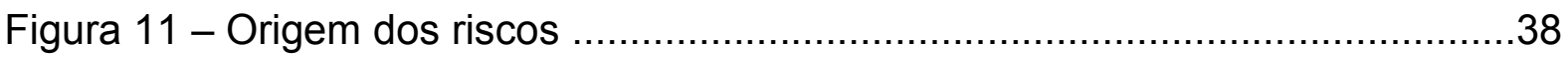

Figura 12 - Evolução dos riscos nas fases de desenvolvimento dos projetos .........42

Figura 13 - Organização e responsabilidades para o gerenciamento de riscos .......44

Figura 14 - Processos de gerenciamento de riscos do PMBOK ….......................46

Figura 15 - Passos do gerenciamento de riscos da AS/NZS 4360:2004 …............47

Figura 16 - Processos de gerenciamento de aquisições do projeto - PMBOK ........57

Figura 17 - Alocação de riscos em contratos de engenharia e construção ...............60

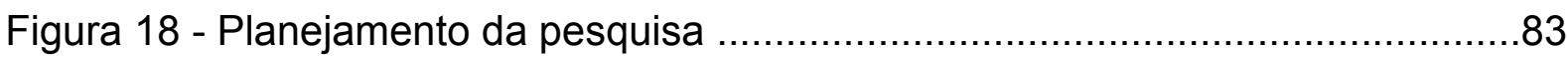

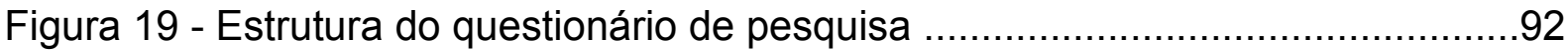

Figura 20 - Importância do gerenciamento de riscos das aquisições - caso A ........97

Figura 21 - Estrutura organizacional típica - caso A ……….............................98

Figura 22 - Estrutura do gerenciamento de riscos das aquisições - caso A .............99

Figura 23 - Matriz de probabilidade x impacto - caso A ………........................100

Figura 24 - Importância do gerenciamento de riscos das aquisições - caso B ......108

Figura 25 - Estrutura organizacional típica - caso B .........................................109

Figura 26 - Metodologia de gerenciamento de riscos das aquisições - caso B …..110

Figura 27 - Estrutura do gerenciamento de riscos das aquisições - caso B ...........111

Figura 28 - Análise preliminar de riscos - caso B ..........................................115

Figura 29 - Criticidade dos pacotes de aquisição - caso B ………….................116

Figura 30 - Análise quantitativa de riscos - caso B .......................................117

Figura 31 - Importância do gerenciamento de riscos das aquisições - caso C ..... 119 
Figura 32 - Estrutura organizacional típica - caso C …................................120

Figura 33 - Estrutura do gerenciamento de riscos das aquisições - caso $C$.........121

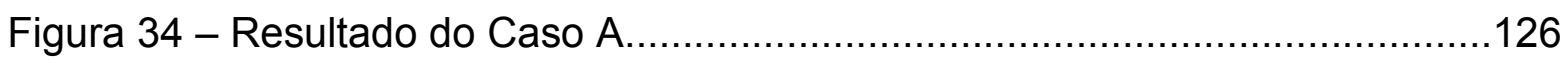

Figura 35 - Resultado do Caso B...............................................................127

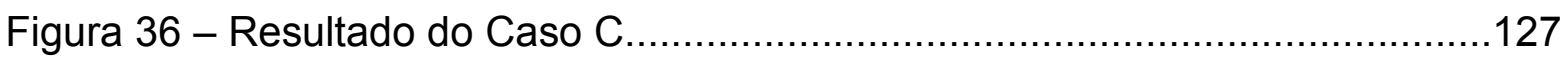

Figura 37 - Resultado consolidado dos casos...........................................128 


\section{LISTA DE TABELAS}

Tabela 1 - Fatores motivadores do gerenciamento de projetos …........................28

Tabela 2 - Principais padrões de gerenciamento de riscos …….......................... 41

Tabela 3 - Estrutura analítica de riscos para projetos de engenharia ....................49

Tabela 4 - Estrutura analítica de riscos para projetos de construção .......................50

Tabela 5 - Estrutura analítica de riscos típica para projetos da ABB .......................51

Tabela 6 - Formato estruturado de descrição de um risco ….................................54

Tabela 7 - Riscos da indústria da construção .....................................................62

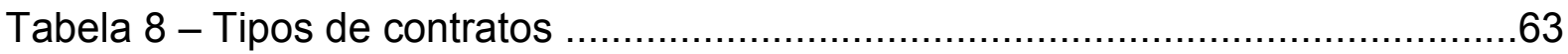

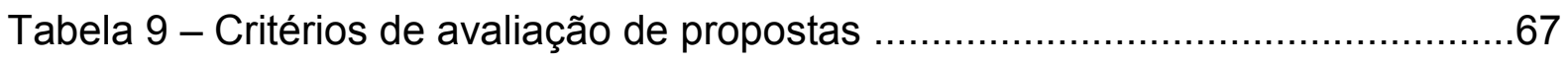

Tabela 10 - Principais riscos e estratégias de mitigação para o contratante ............74

Tabela 11 - Lista de verificação de contratos ......................................................79

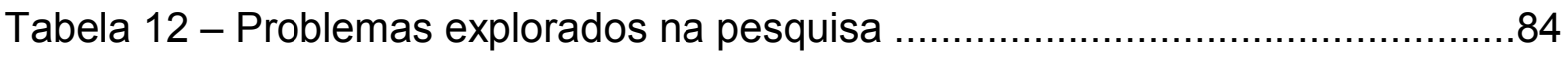

Tabela 13 - Resumo dos procedimentos da pesquisa ........................................

Tabela 14 - Resumo dos resultados dos processos de riscos das

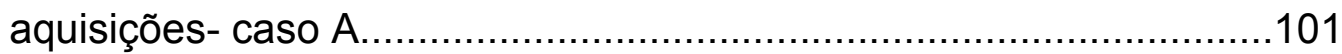

Tabela 15 - Estrutura analítica de riscos de contrato - caso A ............................102

Tabela 16 - Estrutura analítica de riscos de suprimentos - caso A .......................104

Tabela 17 - Resumo dos resultados dos processos de riscos das aquisições- caso B ......................................................................112

Tabela 18 - Estrutura analítica de riscos de contrato - caso B ….........................113

Tabela 19 - Resumo dos resultados dos processos de riscos das

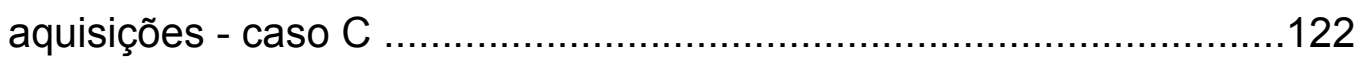

Tabela 20 - Estrutura analítica de riscos de contrato - caso C..............................123

Tabela 21 - Importância do Gerenciamento de Riscos ......................................125

Tabela 22 - Detalhamento dos processos dos casos estudados..........................129

Tabela 23 - Estrutura Analítica de Riscos de Contratos........................................132

Tabela 24 - Estrutura Analítica de Riscos de Suprimentos.................................134

Tabela 25 - Resumo das lições aprendidas...................................................137

Tabela 26 - Resumo das práticas complementares...........................................138 


\section{LISTA DE ABREVIATURAS E SIGLAS}

$\begin{array}{ll}\text { APM } & \text { Association of Project Management } \\ \text { EAP } & \text { Estrutura Analítica de Projetos } \\ \text { EAR } & \text { Estrutura Analítica de Riscos } \\ \text { FERMA } & \text { Federation of European Risk Management Associations } \\ \text { IPA } & \text { Independent Project Analysis } \\ \text { IPMA } & \text { International Project Management Association } \\ \text { PMBOK } & \text { Project Management Body of Knowledge } \\ \text { PMI } & \text { Project Management Institute } \\ \text { PMP } & \text { Project Management Professional } \\ \text { EPCM } & \text { Engineering, Procurement and Construction Management } \\ \text { EPC } & \text { Engineering, Procurement and Construction } \\ \text { FEED } & \text { Front End Engineering Design }\end{array}$




\section{SUMÁRIO}

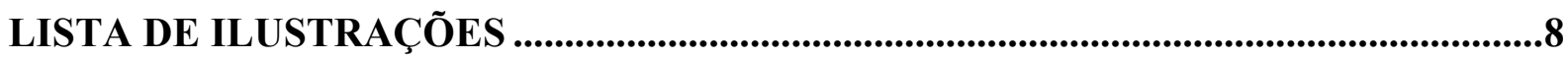

LISTA DE TABELAS ..............................................................................................................10

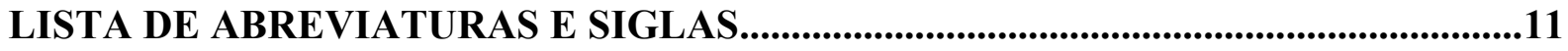

1 INTRODUÇÃ

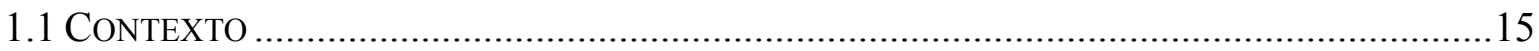

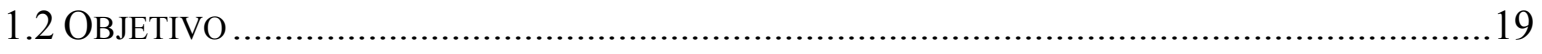

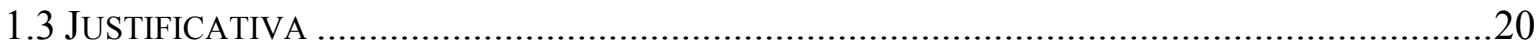

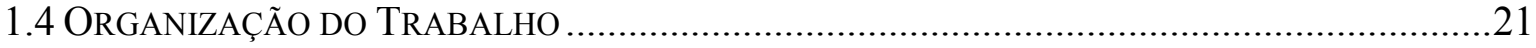

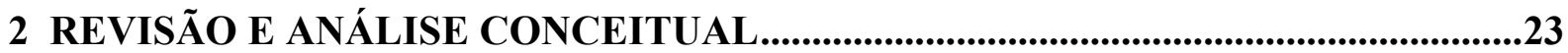

2.1 CONTEXTUALIZAÇÃO DO GERENCIAMENTO DE PROJETOS........................23

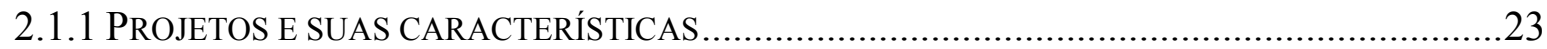

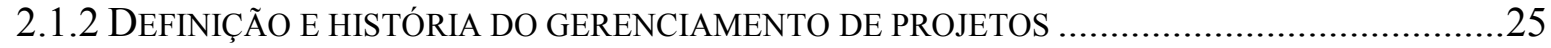

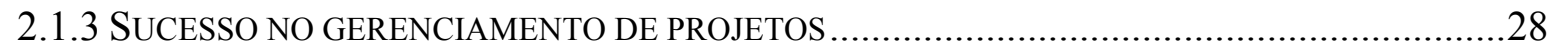

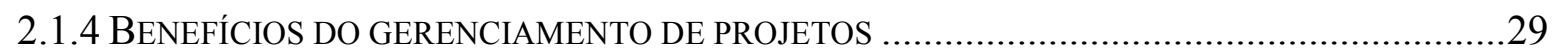

2.1.5 Áreas e Processos do Gerenciamento de Projetos .............................................30

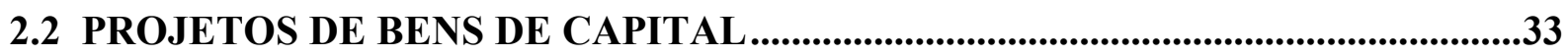

2.2.1 DEFINIÇÃO

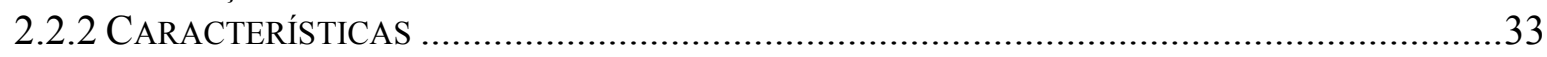

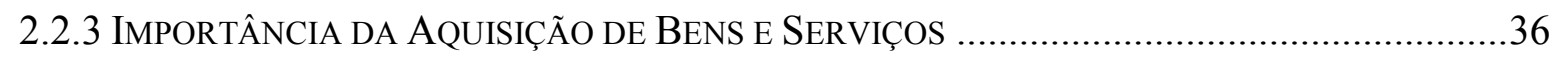

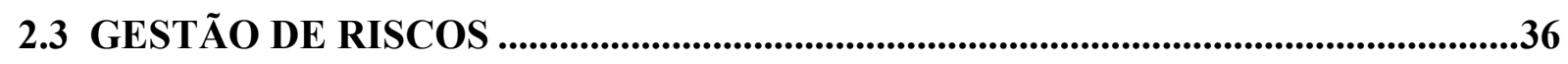

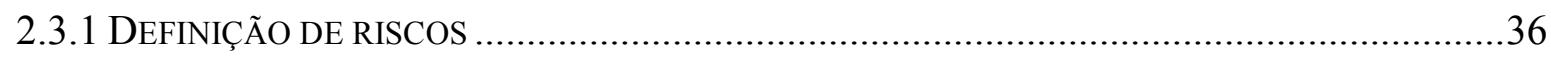

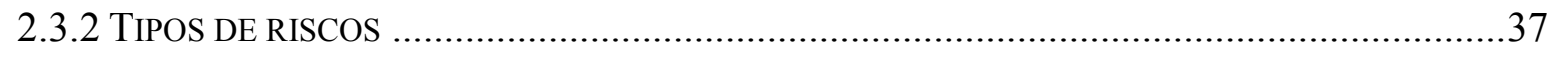

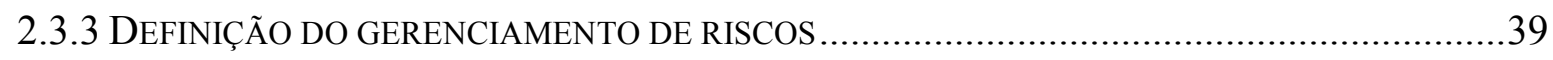

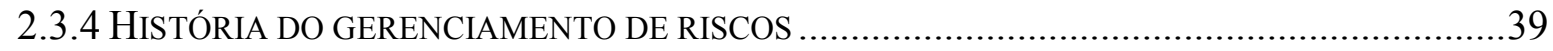

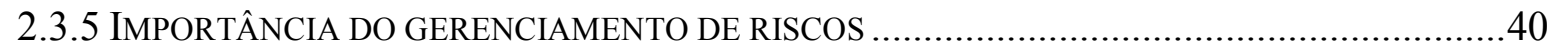

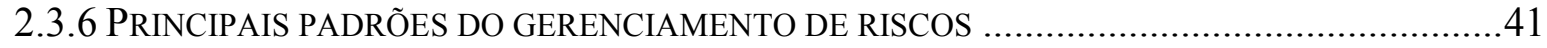

2.3.7 EVOLUÇÃO DOS RISCOS DURANTE AS FASES DE DESENVOLVIMENTO DOS PROJETOS .....42

2.3.8 ABORDAGENS PARA O GERENCIAMENTO DE RISCOS ....................................................43

2.3.9 ORGANIZAÇÃO E RESPONSABILIDADES PARA O GERENCIAMENTO DE RISCOS ................44

2.3.10 PROCESSOS DE GERENCIAMENTO DE RISCOS (PMBOK) ...........................................45

2.3.11 PROCESSOS DO GERENCIAMENTO DE RISCOS (AS/NZS 4360:2004) ...........................47

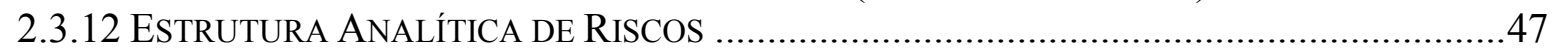

2.3.13 CONSIDERAÇÕES PARA A IMPLANTAÇÃO DO GERENCIAMENTO DE RISCOS ...................52

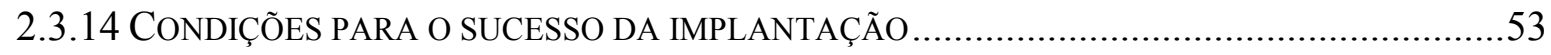

2.4 PROCESSOS DE AQUISIÇÃO DE BENS E SERVIÇOS ..........................................55

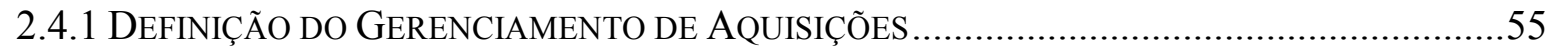

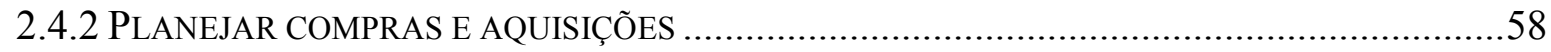

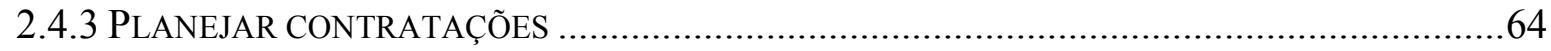




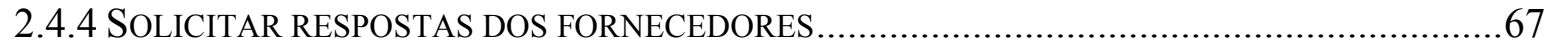

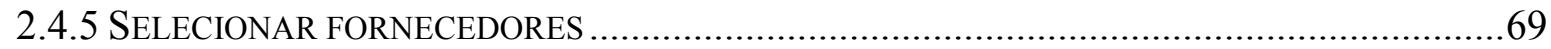

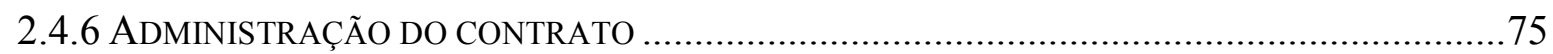

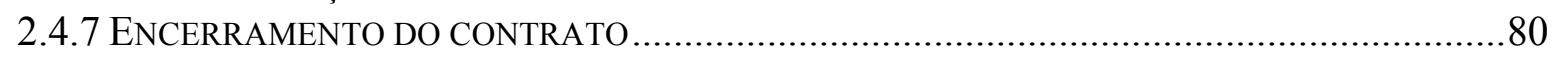

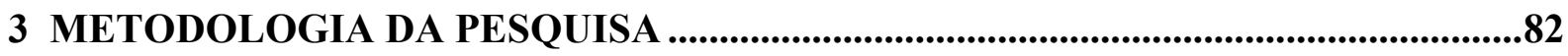

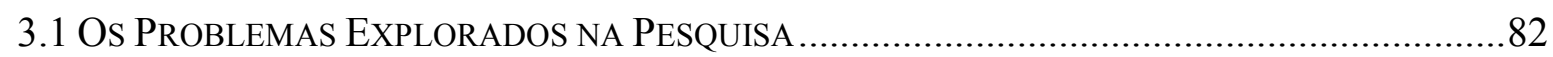

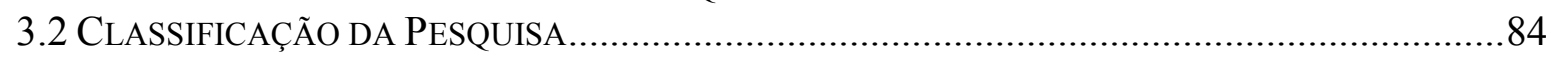

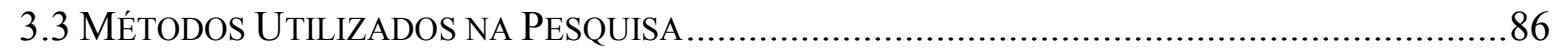

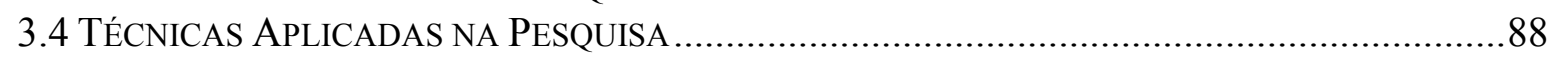

3.5 Procedimentos Considerados NA PESQUISA ........................................................ 90

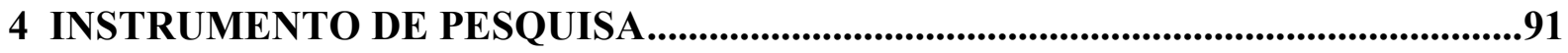

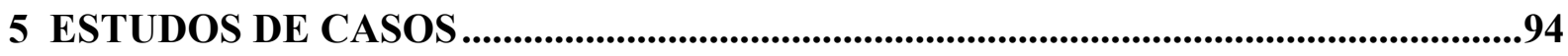

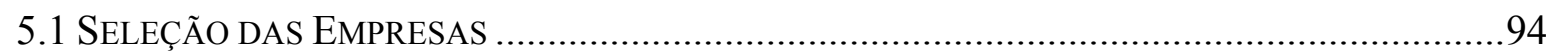

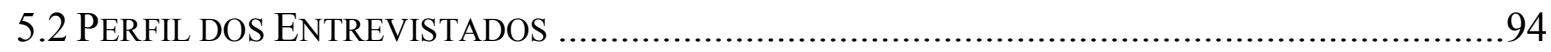

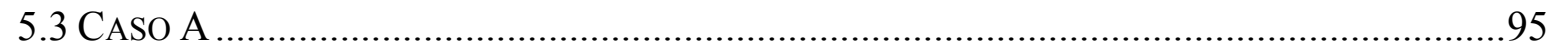

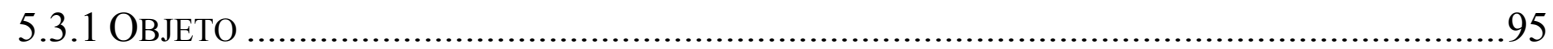

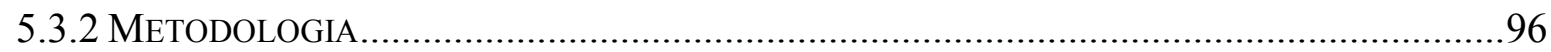

5.3.3 GERENCIAMENTO DE RISCOS DAS AQUISIÇÕES NA EMPRESA A .....................................97

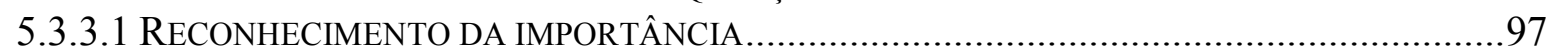

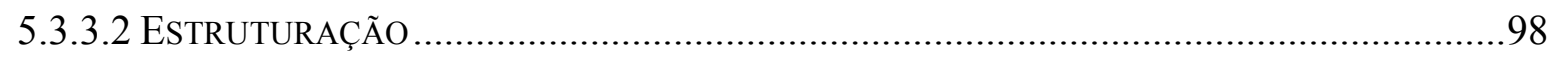

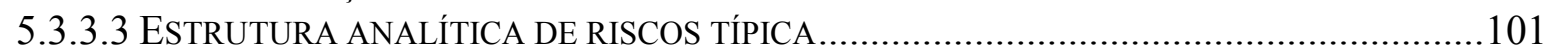

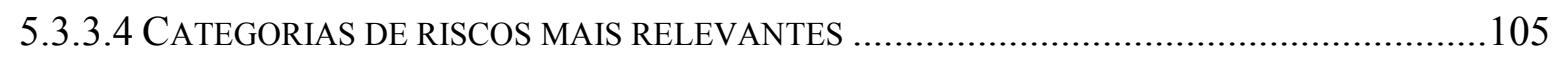

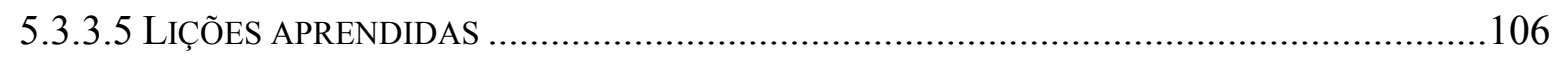

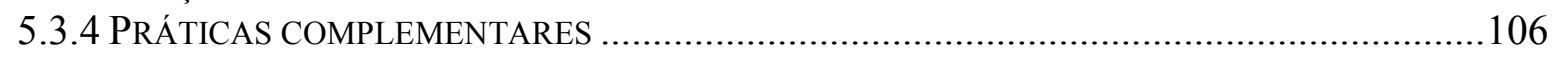

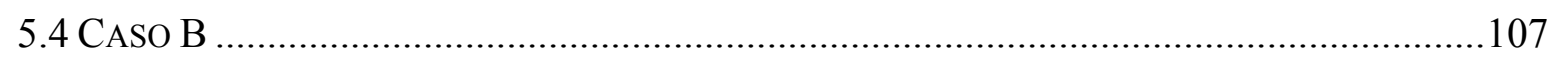

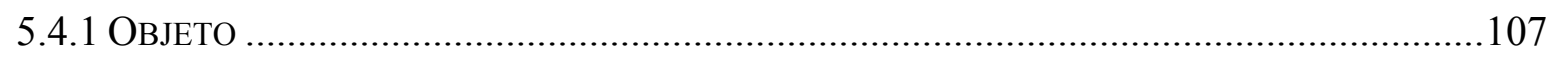

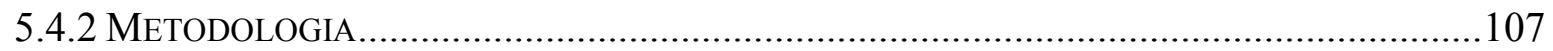

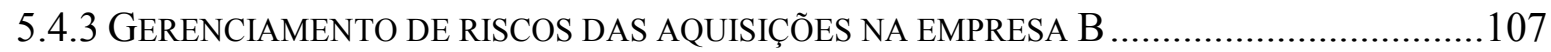

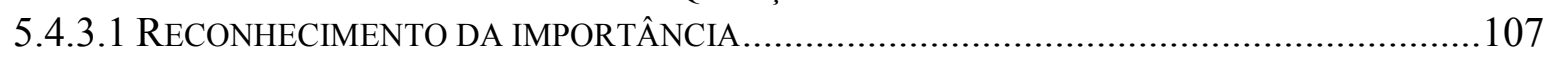

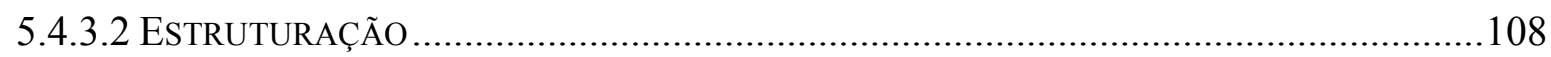

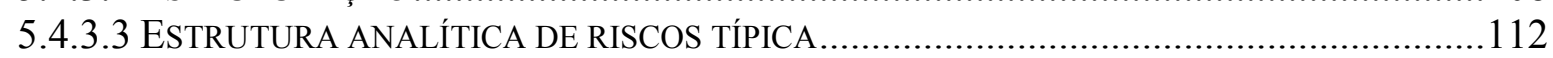

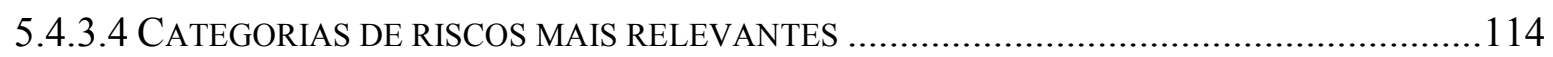

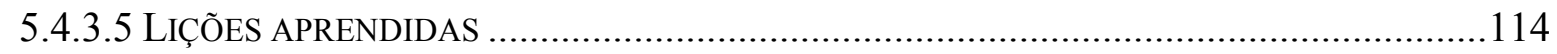

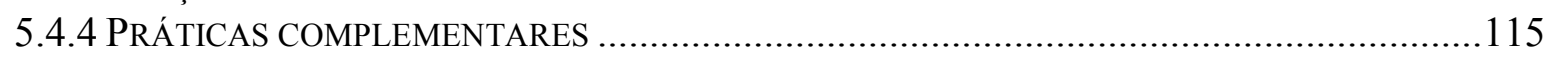

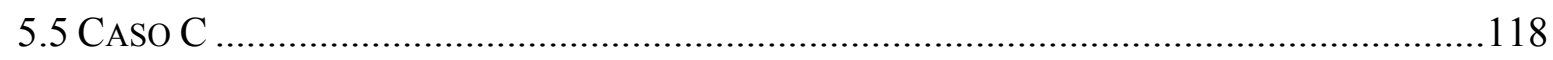

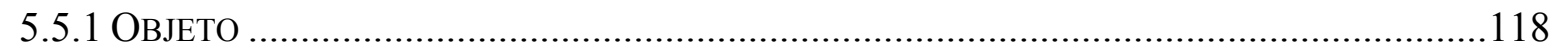

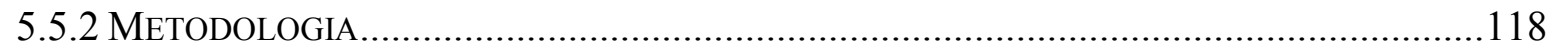

5.5.3 GERENCIAMENTO DE RISCOS DAS AQUISIÇÕES NA EMPRESA C .................................118

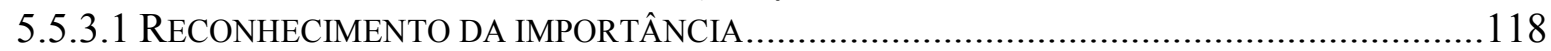

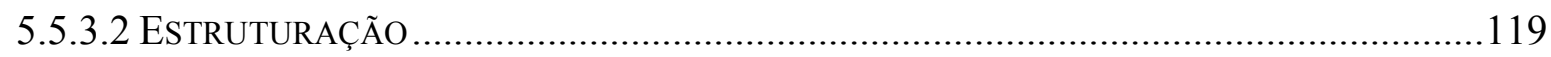

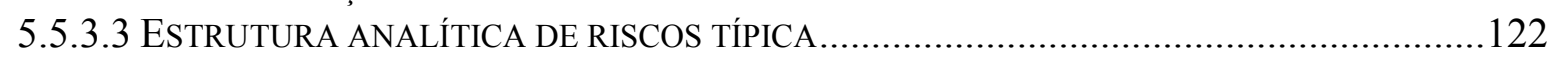

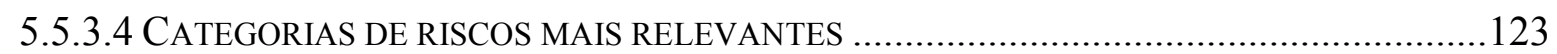

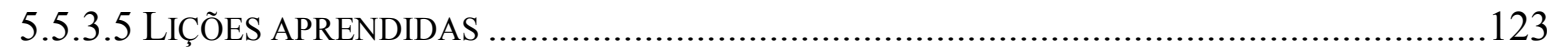

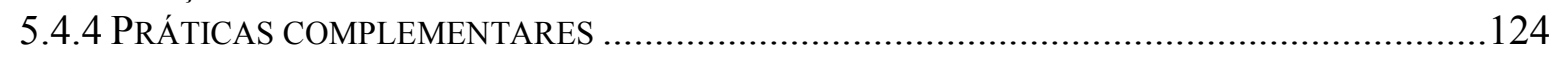

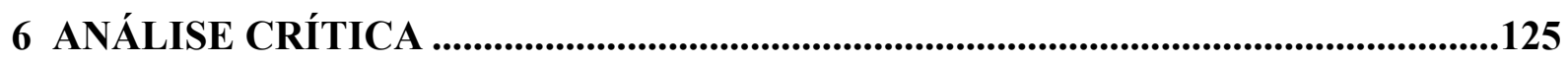

6.1 IMPORTÂNCIA DO GERENCIAMENTO DE RISCOS DAS AQUISIÇÕES..................................125

6.2 ESTRUTURAÇÃO, AdERÊNCIA E CONSOLIDAÇÃO DAS PRÁTICAS ...................................126 


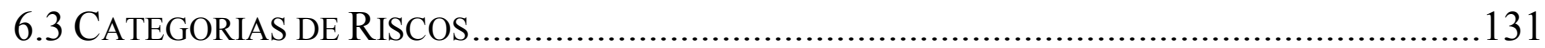

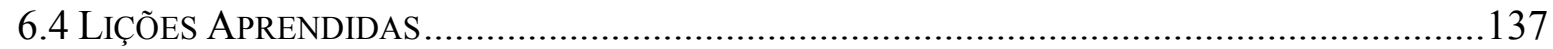

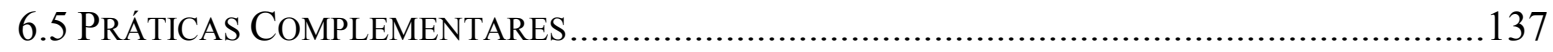

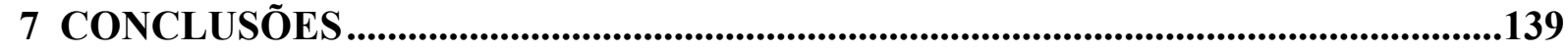

7.1 CONCLUSÃO

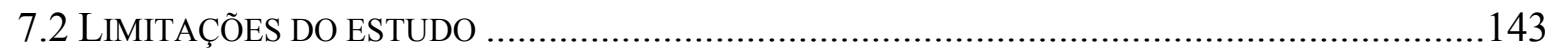

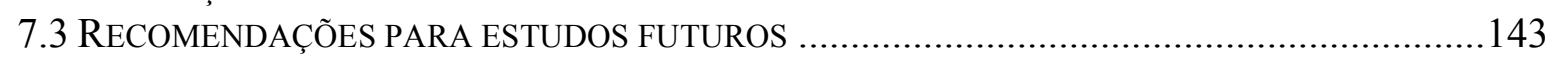

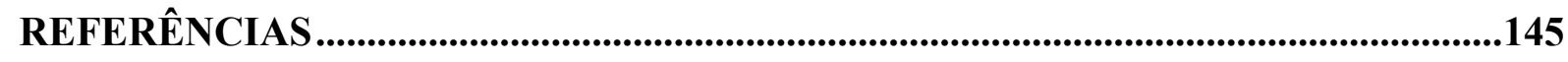

APÊNDICE A - QUESTIONÁRIO DE APOIO À PESQUISA.......................................150

APÊNDICE B - DEFINIÇÃO DAS CATEGORIAS DE RISCOS...................................160 


\section{INTRODUÇÃO}

Durante a última década (RAZ; HILLSON, 2005) houve um interesse em melhorar nossa habilidade para lidar com incertezas, e especialmente aquelas com impacto negativo a nível organizacional. Isto levou ao desenvolvimento e aplicação de ferramentas, técnicas, processos e metodologias as quais são tipicamente classificadas sob o nome de gestão de riscos.

A gestão de riscos é reconhecida como um instrumento valioso para os negócios e sucesso dos projetos (PROJECT MANAGEMENT INSTITUTE, 2004; ASSOCIATION FOR PROJECT MANAGEMENT, 2004), uma vez que analisa e trata as incertezas de uma maneira pró-ativa com o objetivo de minimizar ameaças, maximizar oportunidades e aperfeiçoar as realizações dos objetivos organizacionais.

Segundo Raz e Hillson (2005) é importante distinguir entre os riscos de gestão de negócios, uma área de especialidade do campo de finanças e seguros, preocupados principalmente com os ganhos e perdas monetárias e a gestão dos riscos operacionais, a qual está preocupada com as incertezas inerentes das atividades de execução das organizações para alcançar suas metas e objetivos, as quais incluem o desenvolvimento e implantação dos seus projetos.

Este trabalho analisa especificamente a gestão dos riscos operacionais do processo de aquisição de bens e serviços para a implantação de projetos de bens de capital, compreendidos desde o processo de planejamento da aquisição até o encerramento do contrato.

\subsection{Contexto}

De acordo com pesquisas desenvolvidas pelo (IPA, 2004) a maioria dos projetos de bens de capital falha para alcançar os seus objetivos. A figura 1 resume os índices de sucesso destes projetos. 
Figura 1 - Índice de sucesso dos projetos

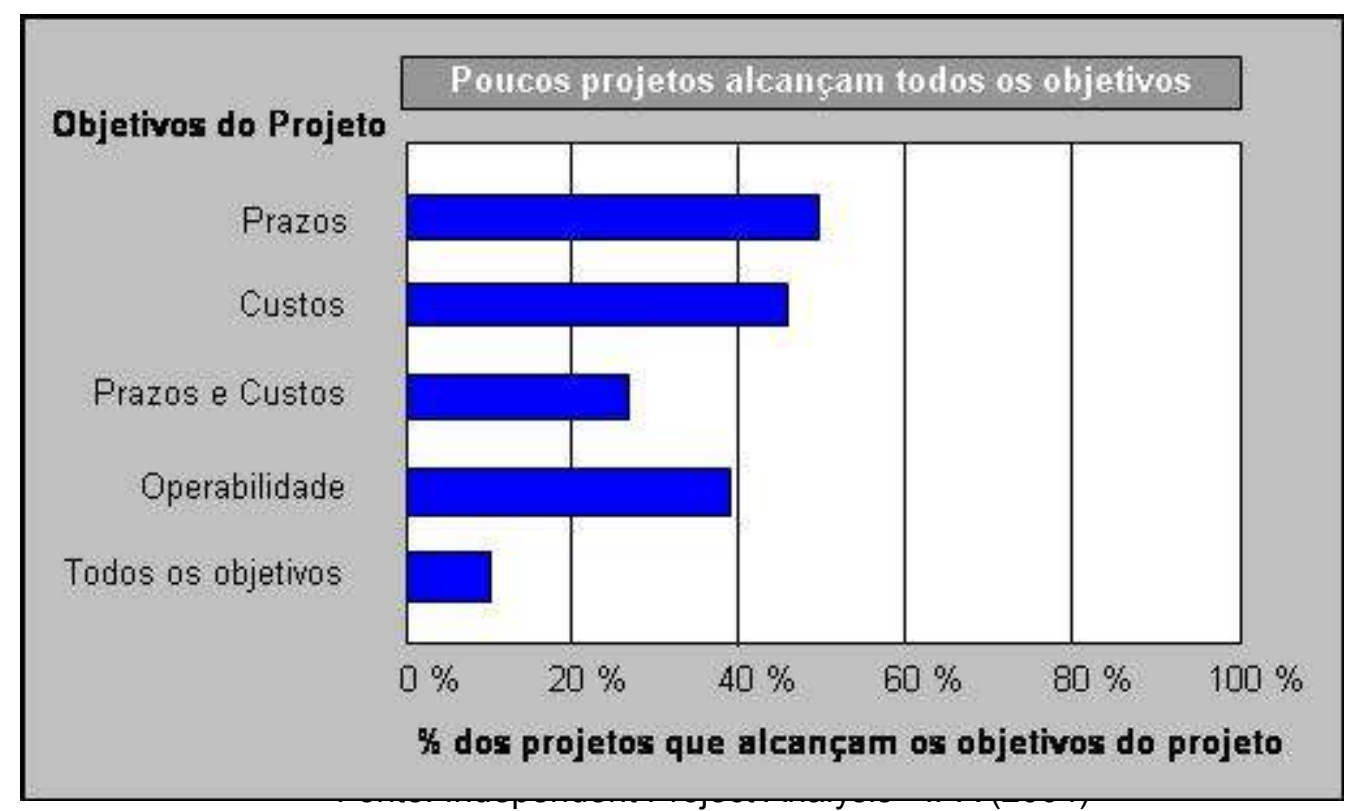

(KERZNER, 2004) comenta que na próxima década as empresas encontrarão desafios ainda maiores para a implantação dos seus projetos. Estes desafios serão devido à tendência de aumento dos custos da mão de obra, aumento do preço das "commodities", da demanda crescente dos sindicatos, pressão do mercado acionário, dentre outras.

Segundo (HENRIE; HEDGEPETH, 2006) enquanto o gerenciamento das aquisições é sempre essencial para o sucesso dos projetos, o panorama atual da globalização demandando das empresas uma maior competitividade através da produção de produtos ou serviços mais rápidos, mais baratos e melhores e a necessidade crescente da implantação de projetos a nível internacional intensificam a necessidade de um gerenciamento das aquisições ainda mais efetivo.

Para um gerenciamento de aquisições mais efetivo para os projetos de bens de capital destaca Ferrari (2006) que é necessário entender o ambiente destas aquisições.

Os projetos e as operações segundo o PMBOK (2004) diferem principalmente no fato de que as operações são contínuas e repetitivas, enquanto os projetos são temporários e exclusivos. Neste sentido destaca Ferrari (2006) que o gerenciamento 
das aquisições para os projetos requer um esforço diferenciado daquele normalmente requerido para as operações. Por exemplo, devido aos projetos serem temporários e exclusivos, as aquisições para os projetos muitas vezes são exclusivas, ou seja, a organização ainda não teve a experiência da aquisição daqueles bens ou serviços anteriormente e não conhece bem o mercado e seus fornecedores.

O PMBOK (2004) menciona que pode acontecer das equipes de projeto e aquisição serem constituídas especificamente para aquele projeto, tendo que estruturar os procedimentos de gerenciamento do projeto e aquisições muitas vezes inexistentes ou não adaptados para as necessidades reais do projeto.

Outra característica importante segundo o IPA (2004) é que devido aos projetos serem planejados e executados em um contexto regional, social, econômico e ambiental diferente, o processo de gerenciamento das aquisições deve levar em consideração estas variáveis na definição de suas estratégias.

Para o entendimento do tema estudado também faz-se importante a definição do conceito e exemplos de projeto de bens de capital. Segundo o IPA (2004) projeto de bens de capital são aqueles projetos que envolvem instalações, equipamentos e construções, desenvolvidos para a produção de outros bens ou serviços tais como:

- Projeto de uma usina hidroelétrica;

- Projeto de uma refinaria de petróleo;

- Projeto de um terminal de armazenamento e transporte de combustíveis;

- Projeto de uma unidade portuária;

- Projeto de uma usina de beneficiamento mineral;

- Projeto de uma estrada ferroviária;

- Projeto de uma estrada rodoviária;

- Projeto de uma indústria farmacêutica;

- Projeto de uma indústria automotiva;

- Projeto de uma indústria eletroeletrônica;

- Dentre outros. 
Possuem também algumas características importantes que caracterizam o ambiente das aquisições nestes projetos. De forma geral o projeto de bens de capital destaca o IPA (2004) são elaborados de forma progressiva, de maneira que o escopo do projeto e do produto do projeto vão sendo construídos em fases. Desta forma Ferrari (2006) menciona que o escopo de uma aquisição também pode sofrer variações durante o ciclo de vida do projeto exigindo muitas vezes renegociações e ou aditivos em contratos pré-estabelecidos.

A figura 2 descreve um ciclo de vida típico de um projeto de bens de capital. Percebe-se que a capacidade de influência no resultado do projeto está na fase do seu planejamento, enquanto os investimentos são efetivamente altos na fase de implantação. Esta característica dos projetos de acordo com o IPA (2004) mostra a necessidade de um planejamento estruturado do projeto e das aquisições nas fases iniciais, a partir da definição do projeto conceitual.

Figura 2 - Ciclo de vida típico dos projetos de bens de capital

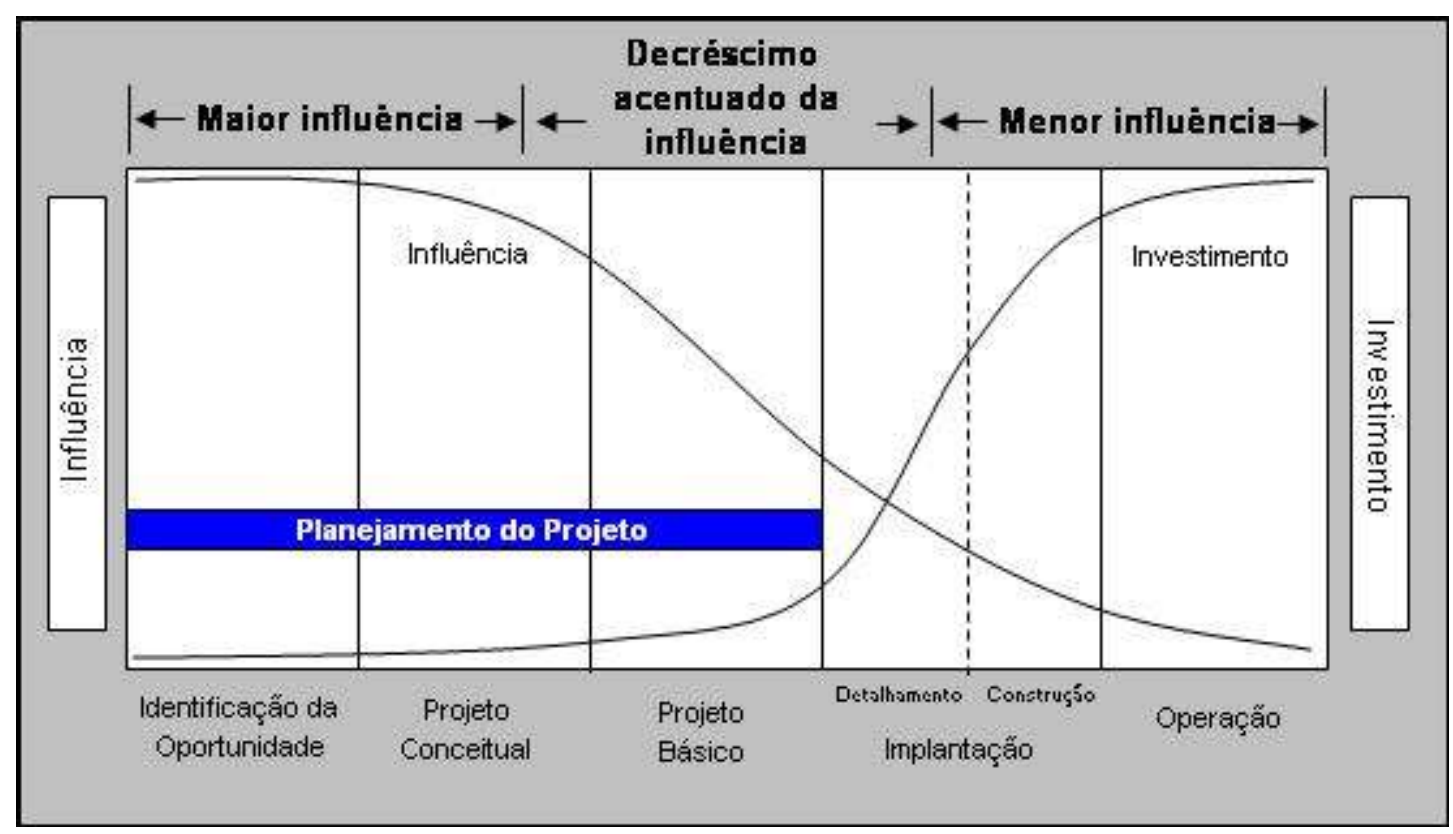

A aquisição dos bens e serviços para a implantação de tais projetos de bens de capital, principalmente para os empreendimentos de grande porte, segundo o IPA (2004) normalmente são realizadas pela própria organização gestora do projeto, que se utiliza da contratação de empresas externas, uma vez que as organizações buscam focar nos seus eixos de negócios, buscando a competitividade. Desta 
maneira destaca Ferrari (2006) o gerenciamento de projetos passa a ser também um gerenciamento de contratos, exigindo uma estruturação adequada dos contratos e da sua gestão pela empresas.

De acordo (HENRIE; HEDGEPETH, 2006) tem-se estimado que as melhorias dos processos de aquisição e logística dos projetos através de um planejamento estruturado podem contribuir com os maiores ganhos nos custos e prazos de implantação dos projetos. Exemplos de 25 a 50\% de redução nos prazos e custos podem ser obtidos quando as empresas se organizam atuando de forma adequada nestes processos.

Não é por acaso que segundo Kerzner (2003) as organizações cada vez mais têm reconhecido o valor das práticas de gerenciamento de projetos na realização dos seus objetivos de negócios. Este reconhecimento tem demandado dos profissionais, estudiosos e acadêmicos do gerenciamento de projetos um detalhamento, aperfeiçoamento e customização destas práticas.

\subsection{Objetivo}

O objetivo deste trabalho está relacionado com o estudo do gerenciamento de riscos aplicado nas aquisições de bens e serviços para os projetos de bens de capital, tendo como foco os seguintes pontos:

- Análise da importância do tema em empresas de relevante atuação no contexto de projetos de bens de capital do mercado brasileiro e internacional;

- Identificação das categorias de riscos mais relevantes para a aquisição de bens e serviços de projetos de bens de capital;

- Avaliação da aderência da teoria da gestão de riscos aplicada nas aquisições de bens e serviços para os projetos de bens de capital com as práticas das empresas.

Para a adequada exploração destes pontos, foram definidas as seguintes questões chave a serem respondidas no estudo: 
- As empresas de relevante atuação no contexto de projetos de bens de capital reconhecem o valor do gerenciamento de riscos aplicado na aquisição de bens e serviços para o sucesso dos projetos de bens de capital?

- Como está estruturado o gerenciamento de riscos das aquisições nas empresas de relevante atuação no contexto de projetos de bens de capital do mercado brasileiro e internacional?

- Quais são as categorias de riscos no processo de aquisição mais relevantes do ponto de vista das empresas para o sucesso da implantação dos projetos de bens de capital?

- Qual a aderência entre as práticas aplicadas nas empresas e aquelas definidas na teoria do gerenciamento de riscos aplicada nas aquisições de bens e serviços para os projetos de bens de capital?

- Quais são as práticas relacionadas ao gerenciamento de riscos das aquisições de bens e serviços que já estão consolidadas e aquelas que ainda não encontram práticas comuns identificadas?

\subsection{Justificativa}

Dentre as melhores práticas de gerenciamento de projetos, que envolvem de acordo com o PMBOK (2004) disciplinas como escopo, prazo, custos, qualidade, comunicação, recursos humanos, aquisições, segurança, meio ambiente e a integração destas disciplinas e seus processos, a gestão de riscos é uma das áreas de relevância e que tem sido estudada, detalhada e aplicada em algumas organizações. Porém o tema da gestão de riscos com o foco nas aquisições de bens e serviços em projetos de bens de capital não é comumente encontrado na literatura técnica em gerenciamento de projetos.

Além de tudo isto, nos projetos de bens de capital a aquisição de bens e serviços, como por exemplo, serviços de engenharia, terraplenagem, obras civis, montagem eletromecânica, compra de equipamentos industriais, serviços de gerenciamento, serviços especializados de processos aplicados para as plantas industriais, representa segundo o IPA (2004) um processo crítico para a realização dos objetivos do projeto. 
Estas aquisições destaca Ferrari (2006) envolvem incertezas com relação às especificações de compra, dificuldades na obtenção do produto ou serviço com o mercado fornecedor, problemas nas negociações contratuais, barreiras logísticas entre outras. Podem envolver também oportunidades através da obtenção dos bens e serviços em condições mais favoráveis do que o planejado.

Uma gestão adequada dos riscos do projeto e especificamente dos riscos associados ao processo de aquisição de bens e serviços para os projetos de bens de capital contribuirá para o atendimento dos objetivos do projeto.

\subsection{Organização do Trabalho}

Inicialmente o trabalho faz uma descrição da abrangência e relevância do tema e sua justificativa.

$\mathrm{Na}$ primeira parte faz-se uma contextualização do gerenciamento de projetos, uma análise dos projetos de bens de capital, com as suas principais características e uma descrição da importância da aquisição de bens e serviços para o sucesso destes projetos.

$\mathrm{Na}$ segunda parte faz-se uma revisão e análise conceitual do processo de gerenciamento de riscos e do processo de gerenciamento das aquisições incluindo a identificação das categorias de riscos relevantes para a aquisição mencionadas na literatura técnica.

Na terceira parte faz-se a definição da metodologia de pesquisa mais adequada para o objetivo da pesquisa.

$\mathrm{Na}$ quarta parte faz-se uma descrição do instrumento de pesquisa com o objetivo de analisar o alinhamento da teoria a prática das empresas incluindo a identificação das categorias mais relevantes de riscos para as aquisições e eventuais práticas complementares e lições aprendidas nas empresas para a gestão de riscos das aquisições dos projetos de bens de capital. 
$\mathrm{Na}$ quinta parte faz-se a descrição de todo o processo de seleção das empresas e entrevistados para os estudos de casos e os resultados das entrevistas incluindo as práticas não identificadas na teoria.

Na sexta parte do estudo faz-se uma análise crítica e conclusão com as respostas as perguntas objeto deste estudo e faz-se a descrição da limitação do estudo e recomendações futuras. 


\section{REVISÃO E ANÁLISE CONCEITUAL}

Neste capítulo faz-se uma revisão e análise dos conceitos teóricos relacionados com o tema da gestão de riscos aplicada na aquisição de bens em serviços para os projetos de bens de capital. Iniciando no item $2.1 \mathrm{com}$ uma revisão do ambiente dos projetos e o gerenciamento de projetos, passando para o item $2.2 \mathrm{com}$ uma revisão das características principais dos projetos de bens de capital e a importância das aquisições para estes projetos. No item 2.3 faz-se uma revisão dos conceitos da gestão de riscos, detalhando os seus processos e finalmente no item 2.4 desenvolve-se uma revisão dos processos envolvidos no gerenciamento das aquisições de bens e serviços.

\subsection{CONTEXTUALIZAÇÃO DO GERENCIAMENTO DE PROJETOS}

\subsubsection{Projetos e suas características}

Para contextualizar o gerenciamento de projetos é necessário primeiro entender o que significa projeto. Embora existam várias definições na literatura, o PMI-Project Management Institute (Instituto de Gerenciamento de Projetos) através do PMBOK (2004) e Kerzner (2003) descreve definições simples, mas com desdobramento e interpretações bem abrangentes.

O PMBOK (2004) define projeto como "um esforço temporário empreendido para criar um produto ou serviço único". Enquanto Kerzner (2003, tradução nossa) diz que projeto pode ser considerado como qualquer série de atividades e tarefas que:

- Tem um objetivo específico a ser concluído, dentro de certos requisitos;

- Tem um início e fim definidos;

- Tem um limite de fundos;

- Consome recursos humanos e não humanos (tais como: dinheiro, pessoas, equipamentos, etc.);

- São multifuncionais (ou seja, ocorrem através da interação com vários outros departamentos funcionais). 
Ambos definem projeto com um caráter temporário o que significa que todos os projetos possuem um início e um final definidos. E este final é alcançado quando os objetivos do projeto tiverem sido atingidos, quando se tornar claro que os objetivos do projeto não serão ou não poderão ser atingidos ou quando não existir mais a necessidade do projeto e ele for encerrado.

Martins (2007) menciona que as atividades de um projeto não são simples, atos repetitivos, elas são complexas.

A condição temporária de um projeto segundo o PMBOK (2004) não significa necessariamente de curta duração; muitos projetos duram vários anos. Em todos os casos, no entanto, a duração de um projeto é finita.

É importante também de acordo com o PMBOK (2004) e PMI - Construction Extension (2002) entender e refletir sobre a característica temporária dos projetos e suas influências nos negócios, nas pessoas e na sociedade. Com relação aos negócios a oportunidade ou janela do mercado geralmente é temporária fazendo com que a atratividade de um projeto também seja temporária, de maneira que alguns projetos têm um prazo limitado durante o qual seu produto ou serviço deve ser gerado. Já com relação às pessoas, a equipe do projeto, como uma unidade de trabalho, raramente sobrevive ao projeto - uma equipe criada com o único objetivo de realizar o projeto realizará esse projeto e, em seguida, será desfeita e seus membros serão dispensados ou recolocados quando o projeto for concluído.

A sociedade por sua vez pode sofrer por muitos anos, quando devido à condição temporária dos projetos as equipes não idealizarem o projeto pensando no meio ambiente, nas comunidades locais de implantação daquele projeto e nas gerações futuras.

Wideman (2000) destaca que como o produto e serviço criado pelos projetos são únicos, os riscos envolvidos no seu desenvolvimento são muito altos no início, requerendo uma atenção especial na elaboração do escopo do produto e escopo do projeto. Desta maneira normalmente os projetos são elaborados de forma progressiva. A elaboração progressiva significa desenvolver em etapas melhorando 
a cada passo a definição do escopo. Por exemplo, o escopo será descrito de maneira geral no início do projeto e se tornará mais explícito e detalhado conforme a equipe do projeto desenvolve um entendimento mais completo dos objetivos e das entregas. Principalmente quando o projeto for realizado sob contrato a elaboração progressiva das especificações de um projeto deve ser cuidadosamente coordenada com a definição adequada do escopo do projeto.

Outra característica importante de ser entendida segundo o PMBOK (2004) é a diferença entre trabalhos de projeto e operação. Embora ambos possuam características semelhantes tais como:

- São realizados por pessoas;

- Possuem restrição de recursos;

- São planejados, executados e controlados.

Os projetos e as operações diferem principalmente no fato de que as operações são contínuas e repetitivas, enquanto os projetos são temporários e exclusivos. Este fato segundo Ferrari (2006) pode levar a condições de aquisição de bens e serviços bem diferenciados dos projetos em relação às operações, uma vez que devido a sua condição temporária e exclusiva muitas vezes o relacionamento com os fornecedores também é temporário, dificultando as negociações e desenho de parcerias de médio e longo prazo, com vantagens para ambas as partes.

Projetos também de acordo com o PMBOK (2004) são realizados em todos os níveis da organização podendo envolver uma única pessoa ou muitos milhares de pessoas. Sua duração varia de poucas semanas a vários anos. Também podem envolver uma ou várias unidades organizacionais, como joint ventures e parcerias.

\subsubsection{Definição e história do gerenciamento de projetos}

O gerenciamento de projetos destaca Kerzner (2003) é um tema relativamente moderno e de grande importância para o sucesso das organizações no mundo atual. 
De acordo o PMBOK (2004) o gerenciamento de projetos é a aplicação de conhecimento, habilidades, ferramentas e técnicas às atividades do projeto a fim de atender aos seus requisitos.

Já o gerenciamento de projetos para Kerzner (2003), envolve o planejamento e monitoramento do projeto e inclui itens tais como:

\section{Planejamento do Projeto:}

- Definição dos requisitos do trabalho;

- Definição da quantidade e qualidade do trabalho;

- Definição dos recursos necessários.

\section{Monitoramento do Projeto:}

- Acompanhamento do andamento do projeto;

- Comparação dos resultados atuais com o planejado;

- Análise dos impactos;

- Execução de ajustes.

Historicamente, de acordo com Kerzner (2004) o desenvolvimento do gerenciamento de projetos dentro das organizações esteve diretamente relacionado às necessidades dos negócios.

A figura 3 descreve três tipos de organizações industriais por sua utilização do gerenciamento de projetos. Kerzner (2004) destaca a necessidade crescente do gerenciamento de projetos dentro das organizações para atender às condições do mundo atual de competitividade e globalização demandando das empresas produtos e serviços inovadores, a baixo custo e qualidade sendo desenvolvidos em espaços de tempo cada vez mais curtos. 
Figura 3 - Classificação das Organizações relativas ao gerenciamento de projetos

Organizaçôes de Projetos

Gerenciamento de Projetos

Organizaçổes Hibridas

Gerenciamento de Programas

Organizaçôes de Produção

Gerenciamento de Produtos
- Receita vern da execuçẫo dos projetos

Gerente de Projeto tem a responsabilidade pelos lucros e perdas

- Gerente do Projeto é uma profissẫo reconhecida

- Oportunidades diversas de carreira em gerenciamento de projetos

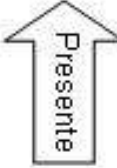

Lucratividade vem da produçẫo, porém empresa tem muitos projetos

Foco no desenvolvimento de novos produtos

Orientada ao mercado

Produtos com ciclos de vida curtos

- Necessidade de rapidez no desenvolvimento de produtos

- Lucratividade vem da produçẫo

- Poucos projetos

Produtos de ciclo de vida longos

Kerzner (2004) menciona que o gerenciamento de projetos 30 anos atrás estava confinado nas empresas prestadoras de serviços para o Departamento de Defesa dos Estados Unidos e empresas de construção e que nos dias de hoje os conceitos do gerenciamento de projetos é aplicado numa variedade de indústrias e organizações tais como: construção, farmacêutica, químico, bancos, hospitais, contabilidade, propaganda, setor público, dentre outros.

Ao longo das últimas décadas alguns fatores marcaram o desenvolvimento do gerenciamento de projetos (KERZNER, 2004). O primeiro fator significativo aconteceu a partir de 1985 quando as empresas reconheceram que a competitividade precisaria também ser na qualidade dos seus produtos e serviços e não somente nos custos. As empresas então começaram a utilizar os princípios do gerenciamento de projetos para a implantação de seus programas de gestão total da qualidade (TQM). Já em 1990 e diante da recessão econômica, as empresas reconheceram a importância da redução dos prazos de desenvolvimento dos seus produtos, através da utilização da engenharia simultânea promovendo as técnicas de programação dos prazos do gerenciamento de projetos. A partir daí vários outros fatores citados na tabela 1 motivaram o desenvolvimento do gerenciamento de projetos. 


\begin{tabular}{|c|r|}
\hline Período & Fatores Motivadores \\
\hline $1960-1987$ & Sem grandes fatores motivadores \\
\hline 1985 & TQM - Gestẫo Total da Qualidade \\
\hline 1990 & Engenharia Simultânea \\
\hline $1991-1992$ & Equipes Autogeridas e Delegaçẫo de Autoridade \\
\hline 1993 & Controle de Custos com visẫo de Ciclo de Vida \\
\hline 1994 & Gestẫo do Controle de Mudanças de Escopo \\
\hline 1995 & Gestẫo de Riscos \\
\hline 1996 & Equipes Multifuncionais Itinerantes \\
\hline $1997-1998$ & Equipes Globais \\
\hline 1999 & Modelos de Maturidade \\
\hline 2000 & Planejamento Estratégico para Gestẫo de Projetos \\
\hline 2001 & Relatório de Status via Intranet \\
\hline 2002 & Modelos de Planejamento da Capacidade \\
\hline 2003 &
\end{tabular}

Fonte: Adaptado de Kerzner (2004)

\subsubsection{Sucesso no gerenciamento de projetos}

No gerenciamento de projetos a pessoa responsável pela realização dos objetivos do projeto é o chamado gerente de projeto, ele deve interagir com os interessados no projeto para alcançar estes objetivos (KERZNER, 2003) ; (PMBOK, 2004).

Segundo (KERZNER, 2003) gerenciar um projeto inclui:

- Identificação das necessidades;

- Estabelecimento de objetivos claros e alcançáveis;

- Balanceamento das demandas conflitantes de qualidade, escopo, tempo e custo;

- Adaptação das especificações, dos planos e da abordagem às diferentes preocupações e expectativas das diversas partes interessadas.

O sucesso do gerenciamento de projetos segundo o PMBOK (2004) e PMI Construction Extension (2002) que inicialmente era medido pelas dimensões prazo, custos e qualidade atualmente pode utilizar também as dimensões do escopo, comunicação, recursos humanos, aquisições, riscos, segurança e meio ambiente.

Kerzner (2003) menciona que o sucesso no gerenciamento de projetos também está em alcançar os objetivos do projeto através da utilização efetiva e eficiente dos recursos e com a aceitação do cliente. 


\subsubsection{Benefícios do gerenciamento de projetos}

Infelizmente, segundo Kerzner (2003) os benefícios do gerenciamento do projeto não podem ser alcançados sem lidar com os seguintes obstáculos:

- Complexidade dos projetos;

- Requisitos especiais dos clientes e mudanças de escopo;

- Reestruturação organizacional;

- Riscos do projeto;

- Mudanças em tecnologia;

- Planejamento e precificação antecipados.

No entanto um gerenciamento de projetos eficaz segundo o PMBOK (2004) exige que a equipe de gerenciamento de projetos entenda e use o conhecimento e as habilidades de pelo menos cinco áreas de especialização, conforme mostrado na figura 4.

Figura 4 - Áreas de especialização do gerenciamento de projetos

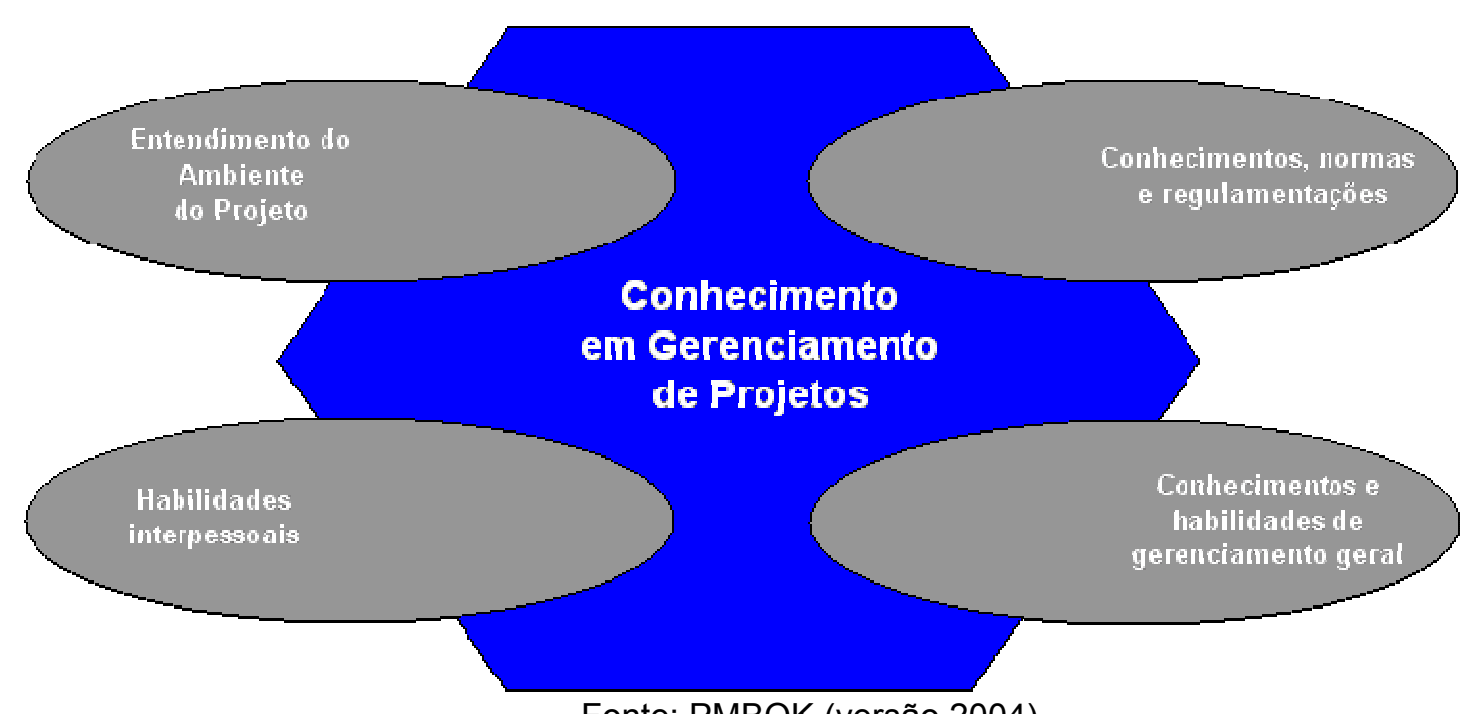

Fonte: PMBOK (versão 2004)

De forma geral segundo Kerzner (2004), as empresas que resolveram adotar o gerenciamento de projetos têm encontrado benefícios acima de suas expectativas. A figura 5 mostra alguns destes benefícios comparando as visões do passado e atuais do gerenciamento de projetos. 
- O gerenciamento de projetos requer mais pessoas e aumentará os custos fixos

- Lucratividade pode diminuir

- O gerenciamento de projetos aumenta a quantidade de mudanças de escopo

- O gerenciamento de projetos cria instabilidade organizacional e aumenta os conflitos

- O gerenciamento de projetos não acrescenta beneficios para o cliente

- O gerenciamento de projetos cria problemas

- Somente grandes projetos precisam do gerenciamento de projetos

- O gerenciamento de projetos aumenta os problemas de qualidade

- O gerenciamento de projetos cria problemas de poder e autoridade

- O gerenciamento de projetos nẫo otimiza os recursos, pois olha somente os projetos

- O gerenciamento de projetos entrega produtos para o cliente

- Os custos do gerenciamento de projetos pode reduzir nossa competitividade

- O gerenciamento de projetos permite executar mais atividades em menos tempo e com menos pessoas - Lucratividade aumenta

- O gerenciamento de projetos melhora o controle das mudanças de escopo

- O gerenciamento de projetos faz a organização mais eficiente e efetiva

- O gerenciamento de projetos permite trabalhar mais próximo do cliente

- O gerenciamento de projetos fornece soluçốes para os problemas

- Todos os projetos projetos sẫo beneficiados com o gerenciamento de projetos

- O gerenciamento de projetos melhora a qualidade

- O gerenciamento de projetos reduz o uso inadequado do poder

- O gerenciamento de projetos permite a tomada de melhores decisốes para as empresas

- O gerenciamento de projetos entrega soluções para o cliente

- O gerenciamento de projetos aumenta os negócios

\subsection{5 Áreas e Processos do Gerenciamento de Projetos}

O gerenciamento de projetos que no passado era estruturado nas áreas de tempo, custo e qualidade atualmente (PMBOK, 2004) é realizado também com foco em outras áreas de conhecimento tais como: escopo, recursos humanos, comunicações, riscos, aquisições e integração sendo todas através da aplicação e da integração dos seguintes grupos de processo: iniciação, planejamento, execução, monitoramento, controle e finalização, conforme indicado na figura 6 abaixo:

Figura 6 - Áreas de conhecimento e grupos de processo do PMBOK 


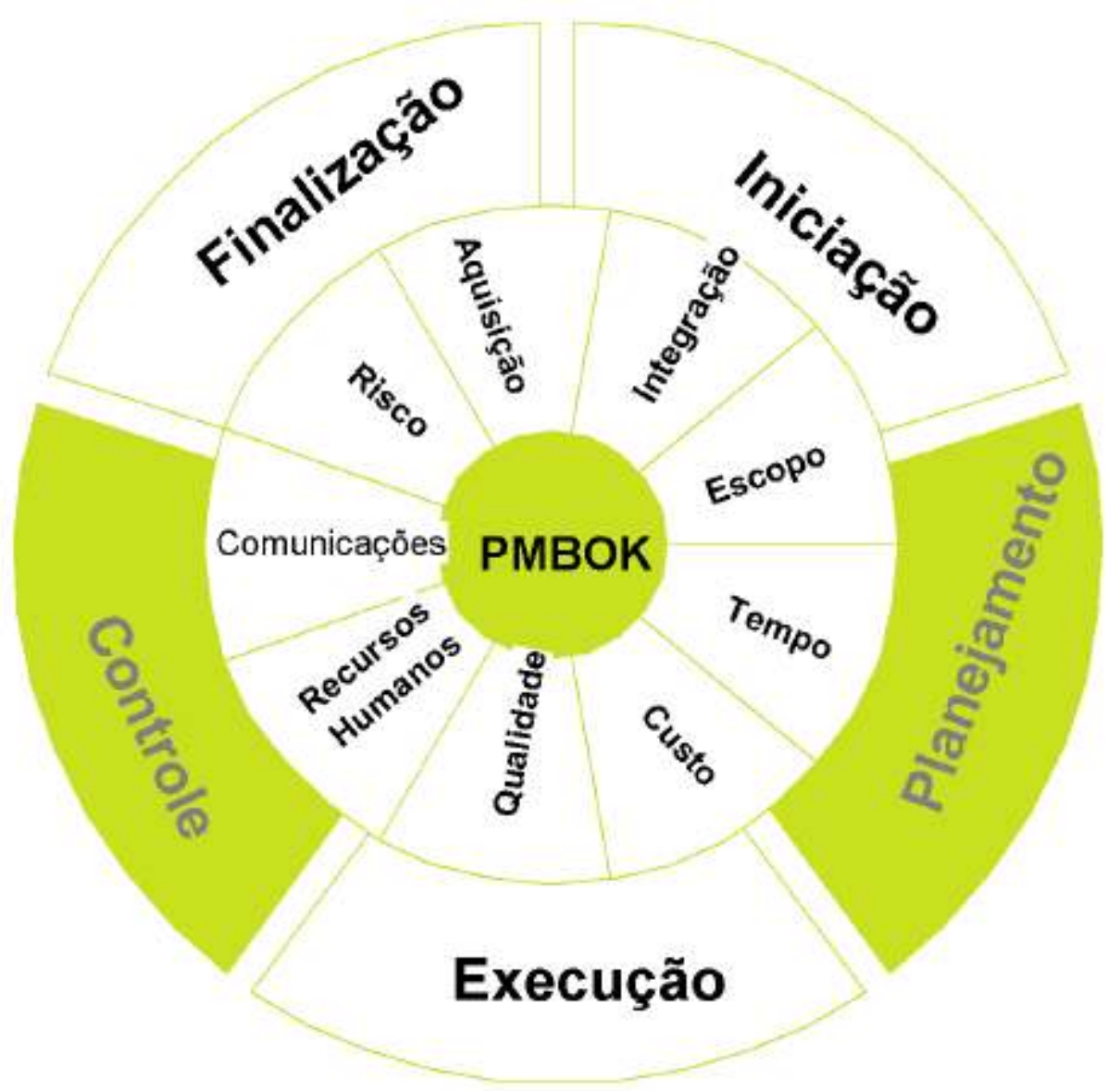

Fonte: Adaptado do PMBOK (2004)

O PMBOK (2004) organiza as áreas de conhecimento em gerenciamento de projetos, através de 44 processos de gerenciamento de projetos, conforme mostrado na figura 7 .

A integração de todos os processos de gerenciamento de acordo com o PMBOK (2004) é bastante relevante e é realizada através do gerenciamento de integração do projeto, que descreve os processos e as atividades que integram os diversos elementos do gerenciamento de projetos, que são identificados, definidos, combinados, unificados e coordenados dentro dos grupos de processos de gerenciamento de projetos.

Figura 7 - Processos de gerenciamento de projetos do PMBOK

\section{GERENCIAMENTO DO PROJETO}


Fonte: PMBOK (2004) 


\subsection{PROJETOS DE BENS DE CAPITAL}

Esta pesquisa foca sua análise nos projetos de bens de capital, o qual possui certas características importantes e algumas diferenciadas com relação aos outros tipos de projetos, as quais precisam ser revisadas e analisadas para fundamentar a análise da gestão de riscos de aquisições e serviços para estes projetos.

\subsubsection{Definição}

Projeto de bens de capital (IPA, 2004) pode ser definido como aqueles projetos que envolvem instalações, equipamentos e construções, construídos para a produção de outros bens ou serviços. Eles podem ser de vários segmentos de negócios, tais como óleo e gás, mineração, infra-estrutura, construção civil, setor farmacêutico, automotivo, elétrico, eletroeletrônico, dentre outros.

\subsubsection{Características}

Como o projeto de bens de capital, normalmente envolve a capitalização de quantidades relevantes de dinheiro para a execução do projeto, segundo Kerzner (2004) sem a elaboração de boas estimativas de custos, controle de custos eficiente e um bom controle dos prazos, o projeto de bens de capital pode levar as empresas a sérios problemas de fluxos de caixa e problemas de relacionamento com os clientes por não cumprimento de contratos com relação à prazos e entrega de produtos.

Uma das forças para que as empresas adquiram a maturidade em gerenciamento de projetos destaca (KERZNER, 2004) é exatamente a execução de projetos de bens de capital. Pois para estes projetos faz-se necessário um gerenciamento de projetos adequado.

Normalmente os projetos de bens de capital são desenvolvidos em fases, desde a sua idealização até a entrega e início das operações (WIDEMAN, 2000). 
Segundo IPA (2004), o ciclo de vida de um projeto é o tempo considerado desde a geração da idéia do projeto até a sua entrada em operação, ou ainda, até a finalização da fase de investimentos, conforme ilustrado na figura 8.

Figura 8 - Ciclo de vida dos projetos

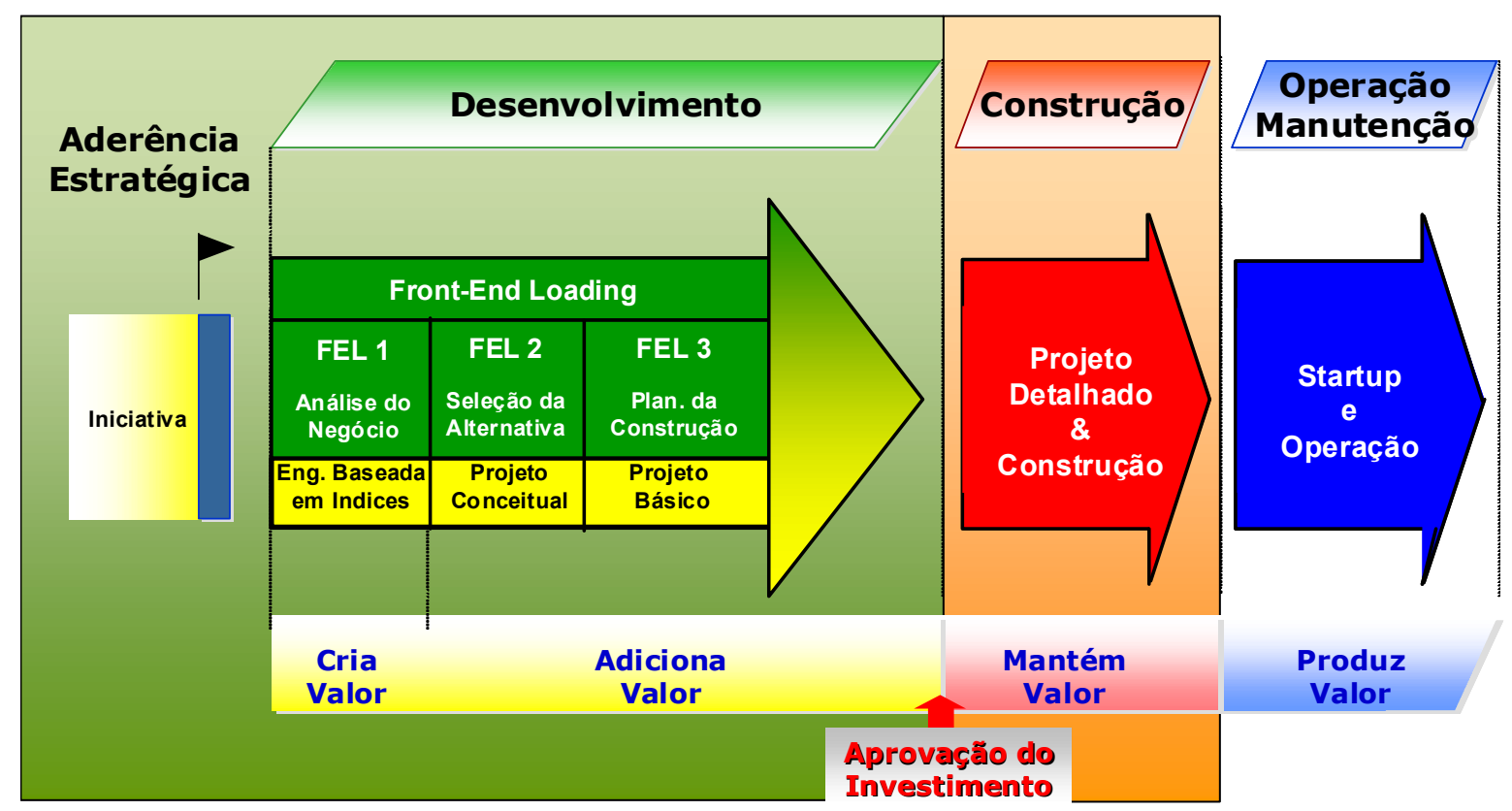

Fonte: IPA (2002)

O projeto de bens de capital em geral segundo o IPA (2004) possui um ciclo de vida que pode variar de aproximadamente 1 ano a 5 anos, com investimentos que podem variar de US\$ 5 milhões a mais de US\$ 1 bilhão de dólares.

Devido ao tipo de produto destes projetos, destaca (ALMEIDA; ANDRADE, 2006), atenção especial é dada aos aspectos da Segurança, Meio Ambiente e Saúde, bem como os aspectos tributários. Outro aspecto importante se refere aos aspectos da responsabilidade social na seleção e implantação destes projetos. O PMI Construction Extension (2000) por sua vez acrescenta aos processos padrões do PMBOK, os processos de gerenciamento de segurança, ambiental, financeiro e pleitos devido ao nível de importância destas áreas para o sucesso dos projetos.

A figura 9 representa graficamente os comportamentos do grau de influência e do nível de investimento em cada uma das fases ao longo do ciclo de vida de um projeto. Segundo Wideman (2000) as decisões tomadas nas fases iniciais têm uma 
grande influência nos resultados do projeto, apesar do pequeno percentual de investimento alocado para estas fases. Já nas fases subseqüentes, o grau de influência é reduzido, enquanto o nível de investimento vai se elevando. Isto revela que durante as fases iniciais do planejamento devem ser buscadas as melhores alternativas para a concepção do projeto. A postergação de decisões e a introdução de modificações relevantes nas fases subseqüentes, quando é alta a realização de investimentos, estão sujeitas a menor flexibilidade e, portanto, à menor capacidade de ajuste dos seus diversos efeitos.

No estágio de planejamento do projeto segundo o IPA (2004) é definido o que será feito, como será feito, quando será feito, quem fará e que recursos serão necessários. Para cada uma das fases de 1 a 3 , devem ser observados os requisitos mínimos próprios, que ao final de cada uma delas é verificado quanto ao nível de informação, de forma que possa haver o prosseguimento para a fase subseqüente.

Figura 9 - Influência e investimentos $\mathrm{x}$ fase do projeto

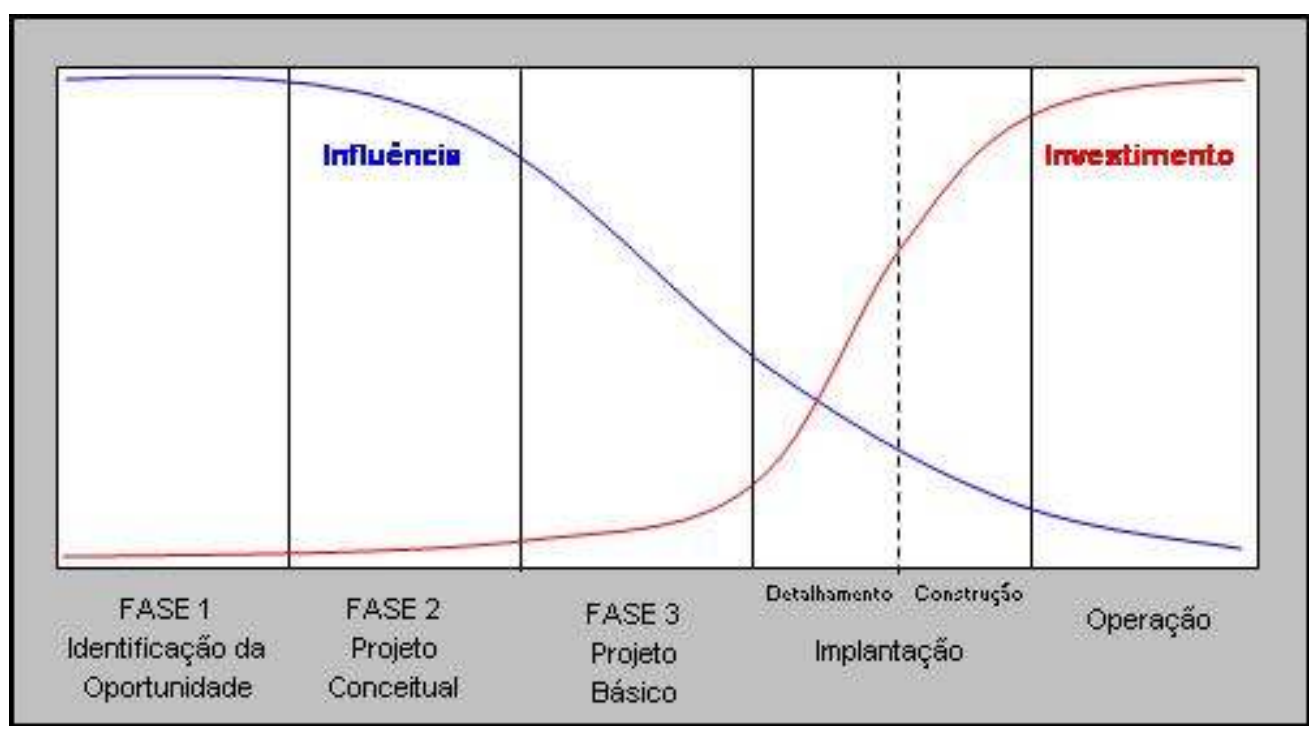

Fonte: Independent Project Analysis - IPA (2004)

O IPA (2004) recomenda ao final da fase do projeto conceitual a definição dos itens críticos de aquisição e contratação para a implantação do projeto.

Neste caso, normalmente devido à criticidade dos prazos de entrega de equipamentos e materiais ou execução de serviços, estas aquisições e contratações são realizadas anteriormente a fase de implantação. 
O planejamento detalhado das estratégias das aquisições e contratações normalmente é realizado no final da fase do projeto básico e é submetido em conjunto e alinhado com os outros capítulos do gerenciamento de projetos, incluindo o de riscos para aprovação da implantação (IPA 2004).

\subsubsection{Importância da Aquisição de Bens e Serviços}

Nos projetos de bens de capital de acordo com Kerzner (2004) a aquisição de bens e serviços representa um processo extremamente crítico para a realização dos objetivos do projeto.

Os prazos e custos do projeto segundo o IPA (2004) estão diretamente ligados a um gerenciamento estruturado e eficaz das aquisições de bens e serviços.

Henrie e Hedgepeth (2006) comenta que é essencial para o sucesso dos projetos a entrega dos equipamentos, materiais e fornecimentos diversos nos prazos acordados, com qualidade e custos efetivos.

\subsection{GESTÃO DE RISCOS}

\subsubsection{Definição de riscos}

Segundo o PMBOK (2004) o risco do projeto "é um evento ou condição incerta que, se ocorrer, terá um efeito positivo ou negativo sobre pelo menos um objetivo do projeto, como tempo, custo, escopo ou qualidade".

As incertezas segundo Cleland e Ireland (2002) respondem pelas premissas do projeto. Quando não há suficientes informações para a tomada de decisões no planejamento do projeto, as premissas preenchem este vazio.

Segundo a FERMA (2003) o risco pode ser definido "como a combinação da probabilidade de um acontecimento e das suas conseqüências".

De acordo com a norma Australiana e da Nova Zelândia (AS/NZS 4360:2004) risco é definido "como a possibilidade de alguma coisa acontecer e impactar nos objetivos. 
Pode ser uma chance de ter-se um ganho ou uma perda. É medido também em termos de probabilidade e conseqüência."

A incerteza quanto ao projeto é identificada em várias áreas dentro de uma organização, Cleland e Ireland (2002) cita algumas delas abaixo:

- Nível de desenvolvimento alcançado como resultado da tecnologia moderna utilizada

- Capacitação organizacional para realizar repetidos processos de gerência de projetos

- Disponibilidade de habilidades técnicas e gerência de projetos

- Disponibilidade de equipamentos para o projeto

- Interfaces externas do projeto

- Fornecedores externos do projeto

- Impasses técnicos

- Resultados de testes para produtos do projeto

\subsubsection{Tipos de riscos}

Segundo Cleland e Ireland (2002) os riscos podem ser divididos em duas categorias: interno e externo, conforme mostra a figura 10.

Figura 10 - Riscos internos e externos dos projetos

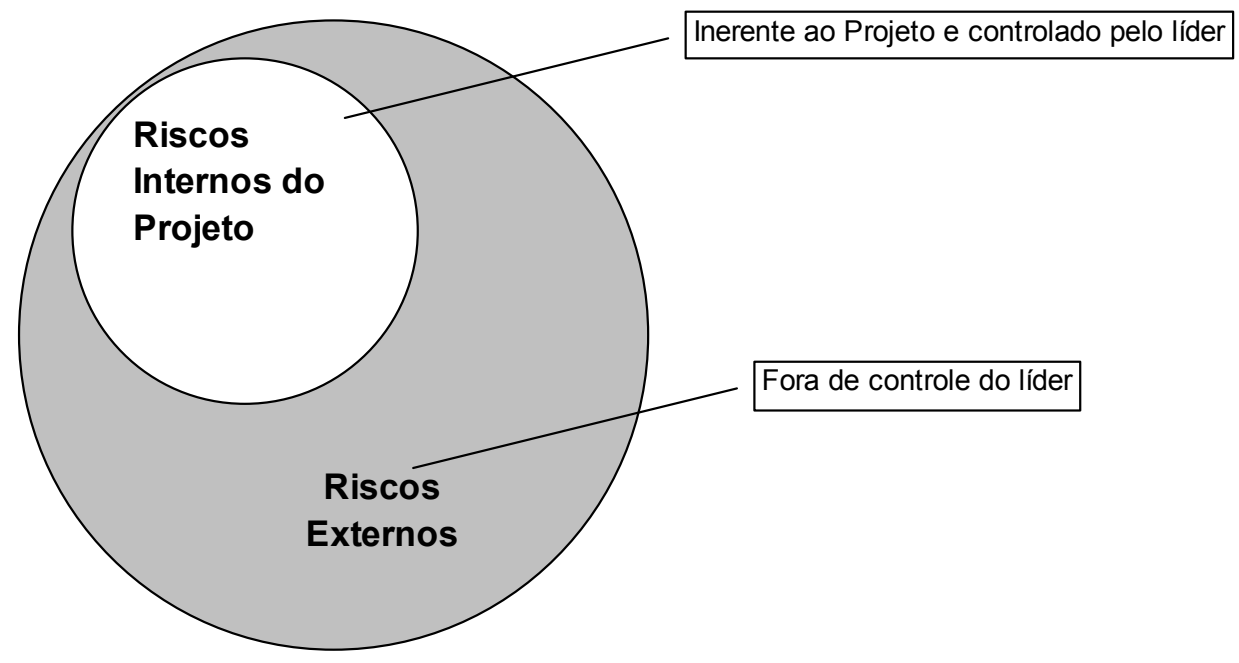

Fonte: Adaptado de Cleland \& Ireland (2002) 
Para Cleland e Ireland (2002) o risco interno é inerente ao projeto, controlado pelo líder podendo reduzi-lo mediante ações diretas, com o desenvolvimento de planos de contingências. Já o risco externo encontra-se fora do controle dos líderes de projeto, como, por exemplo, as interfaces de projeto desconhecidas e cujas definições são feitas por terceiros.

A FERMA (2002) também usa o conceito de riscos internos e externos e diz que a classificação dos riscos pode ser ajustada, e faz a distinção dos mais relevantes entre os riscos puros e os de ordem estratégicos, financeiros, operacionais, etc. A figura 11 abaixo propõe exemplos de alguns dos principais riscos.

Figura 11 - Origem dos Riscos

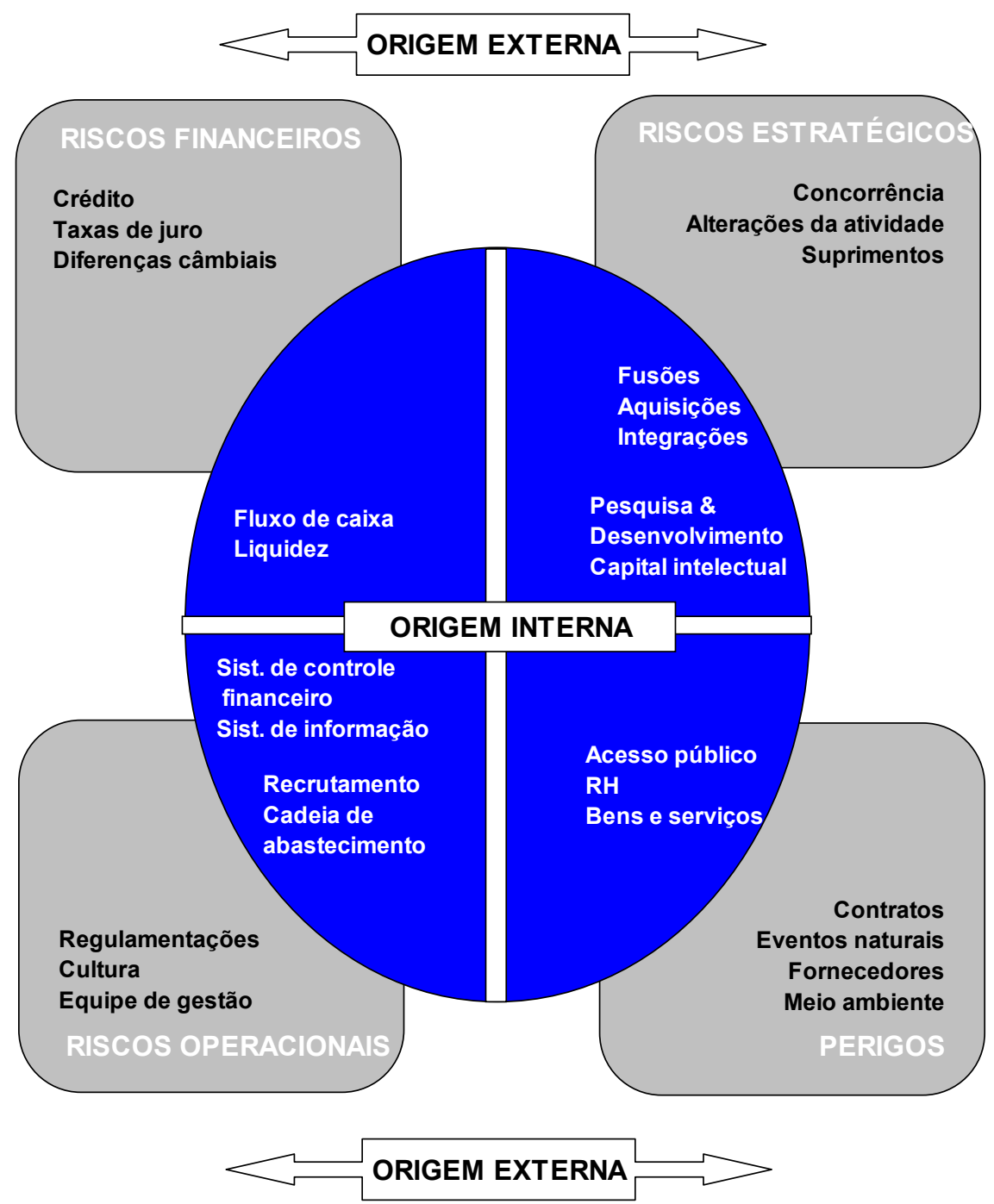

Fonte: FERMA - Federation of European Risk Management Associations (2002) 


\subsubsection{Definição do gerenciamento de riscos}

Segundo Kerzner (2004) o gerenciamento de riscos é "uma maneira organizada de identificação e mensuração dos riscos e desenvolvimento e seleção de opções para gerenciá-los".

Já para o PMBOK (2004) os objetivos do gerenciamento de riscos do projeto é aumentar a probabilidade e o impacto dos eventos positivos e diminuir a probabilidade e o impacto dos eventos adversos ao projeto. E inclui os processos que tratam da realização de identificação, análise, respostas, monitoramento e controle e planejamento do gerenciamento de riscos em um projeto; sendo a maioria desses processos atualizada durante todo o projeto.

\subsubsection{História do gerenciamento de riscos}

A origem do gerenciamento de riscos operacionais segundo Raz e Hillson (2005) vem da disciplina de engenharia de segurança, a qual se preocupa com os perigos físicos advindos como resultado do desempenho indevido dos equipamentos ou operadores. Contudo o gerenciamento de riscos moderno se desenvolveu substancialmente de lá para cá devido a um número de fatores incluindo:

- A visão mais ampla das organizações no contexto das suas várias partes interessadas;

- O crescimento da importância dos projetos como base para planejamento e execução dos trabalhos nas organizações;

- O papel fundamental da tecnologia e sua incerteza inerente;

- A pressão competitiva cada vez maior para redução de prazos de entrega, fazendo com que as organizações iniciem o planejamento e execução dos projetos com informações incompletas;

- A crescente turbulência no ambiente de negócios;

- O rápido crescimento do grau de complexidade envolvido nos projetos e negócios; 
- A tendência contínua da globalização, requerendo ênfase em negócios e equipes virtuais;

- A crescente demanda por atendimento às legislações e regulamentos pelos negócios.

Estes fatores segundo Raz e Hillson (2005) contribuíram para o crescimento do número de livros, artigos e conferências específicas para o gerenciamento de riscos operacionais. Percebe-se que devido a este crescimento, a utilização da nomenclatura "operacional" para estes riscos não é mais necessária, sendo que as pessoas normalmente utilizam-se gerenciamento de riscos quando se referem ao gerenciamento de riscos operacionais.

No passado o gerenciamento de riscos segundo Kerzner (2004) tinha como foco a análise de riscos financeiros e de prazos. Para mitigar os riscos financeiros eram aumentados os orçamentos dos projetos. Para mitigar os riscos de não cumprimento dos prazos, eram acrescentados mais tempo para os cronogramas. Porém a partir de 1990, os riscos técnicos tornaram-se críticos. Simplesmente acrescentando mais tempo ou aumentando o orçamento não eram suficientes para mitigar os riscos técnicos. Basicamente estes riscos técnicos apresentam duas questões principais:

- Podemos desenvolver a tecnologia com as limitações impostas pelo projeto?

- Se pudermos desenvolver a tecnologia, qual o risco dela se tornar obsoleta e quando podemos esperar que isto ocorra?

(KERZNER, 2004) também menciona que somente a partir do acidente com a "Space Shuttle Challenger" em Janeiro de 1986, foi colocada em evidência a importância de um gerenciamento de riscos efetivo.

\subsubsection{Importância do gerenciamento de riscos}

Kerzner (2004) destaca que o gerente de projeto precisa tomar decisões que envolva riscos e que isto requer uma sólida experiência do ambiente de negócios bem como conhecimentos técnicos. 
A gestão de riscos segundo a FERMA (2002) é um elemento central na gestão da estratégia de qualquer organização. É o processo através do qual a organização analisa metodicamente os riscos inerentes à respectiva atividade, com o objetivo de atingir uma vantagem sustentada em cada atividade individual e no conjunto de todas as atividades.

O gerenciamento efetivo de riscos segundo a norma Australiana e da Nova Zelândia (AS/NZS 4360:2004) habilita a maximizar as oportunidades e alcançar os objetivos do projeto.

\subsubsection{Principais padrões do gerenciamento de riscos}

Devido à importância do gerenciamento de riscos foi desenvolvido vários padrões a nível internacional. A tabela 2 mostra os principais padrões do gerenciamento de riscos.

Tabela 2 - Principais padrões do gerenciamento de riscos

\begin{tabular}{|c|c|c|c|c|}
\hline Título & Autor & Ano & Páginas & Escopo \\
\hline \multicolumn{5}{|l|}{ Padröes Nacionais e Internacionais } \\
\hline $\begin{array}{l}\text { 1. IEEE Standard 1540-2001: Standard for } \\
\text { Software Life Cycle Processes - Risk } \\
\text { Management }\end{array}$ & $\begin{array}{l}\text { Institute of Electrical and } \\
\text { Electronic Engineers, USA }\end{array}$ & 2001 & 24 & Projetos/Organização \\
\hline $\begin{array}{l}\text { 2. CEl/IEC 62198:2001: International Standard, } \\
\text { Project Risk Management: Application } \\
\text { Guidelines, 1st edition, 2001-04 }\end{array}$ & $\begin{array}{l}\text { International Electrotechnical } \\
\text { Commission, Switzerland }\end{array}$ & 2001 & 37 & Projetos \\
\hline $\begin{array}{l}\text { 3. JIS Q2001:2001(E): Guidelines for } \\
\text { Development and Implementation of Risk } \\
\text { Management System }\end{array}$ & $\begin{array}{l}\text { Japanese Standards } \\
\text { Association }\end{array}$ & 2001 & 20 & Organização \\
\hline 4. AS/NZS 4360:2004: Risk Management & $\begin{array}{l}\text { Standards Australia / } \\
\text { Standards New Zealand }\end{array}$ & 2004 & 28 & Organização \\
\hline $\begin{array}{l}\text { 5. BS 6079-3:2000: Project Management - Part 3: } \\
\text { Guide to the Management of Business-related } \\
\text { Project Risk }\end{array}$ & $\begin{array}{l}\text { British Standards Institution } \\
\text { (BSI) }\end{array}$ & 2000 & 22 & Projetos \\
\hline $\begin{array}{l}\text { 6. CAN/CSA-Q850-97: Risk Management: } \\
\text { Guideline for Decision-Makers }\end{array}$ & $\begin{array}{l}\text { Canadian Standards } \\
\text { Association (CSA) }\end{array}$ & 1997 & 62 & Organização \\
\hline \multicolumn{5}{|l|}{ Padrōes Profissionais } \\
\hline 7. Risk Management Standard & $\begin{array}{l}\text { Institute of Risk Management } \\
\text { (IRM)/ National Forum for Risk } \\
\text { Management in the Public } \\
\text { Sector (ALARM) / Association } \\
\text { of Insurance and Risk } \\
\text { Managers (AIRMIC), UK }\end{array}$ & 2002 & 18 & Organizaçã̃o \\
\hline $\begin{array}{l}\text { 8. Project Risk Analysis \& Management (PRAM) } \\
\text { Guide, 2nd edition }\end{array}$ & $\begin{array}{l}\text { Association for Project } \\
\text { Management (APM), UK }\end{array}$ & 2004 & 186 & Projetos \\
\hline $\begin{array}{l}\text { 9. Guide to the Project Management Body of } \\
\text { Knowledge (PMBOK) Chapter 11, Project Risk } \\
\text { Management 3rd edition }\end{array}$ & $\begin{array}{c}\text { Project Management Institute, } \\
\text { USA }\end{array}$ & 2004 & 32 & Projetos \\
\hline
\end{tabular}




\subsubsection{Evolução dos riscos durante as fases de desenvolvimento dos projetos}

No início de qualquer projeto segundo Skelton; Thamhain (2006) existe uma grande quantidade de riscos advindos das incertezas ao redor de como o projeto irá avançar. Entretanto Kerzner (2003) destaca que embora os riscos sejam elevados a exposição a eles é mínima desde que até então muito pouco foi de fato comprometido com o projeto. Uma vez que o projeto avança da fase de viabilidade para a fase de implantação, as partes interessadas ficam expostas cada vez mais aos riscos, uma vez que decisões foram tomadas e o projeto e o trabalho de execução tenham iniciado. Este nível de exposição ao risco diminui à medida que o projeto avança. Kerzner (2003) destaca que projetos com ciclo de vida longo pode ter o seu nível de exposição aumentado à medida que reformas e manutenções ameaçam o desempenho operacional dos ativos. Esta evolução dos riscos está descrita na figura 12.

Figura 12 - Evolução dos riscos nas fases de desenvolvimento dos projetos

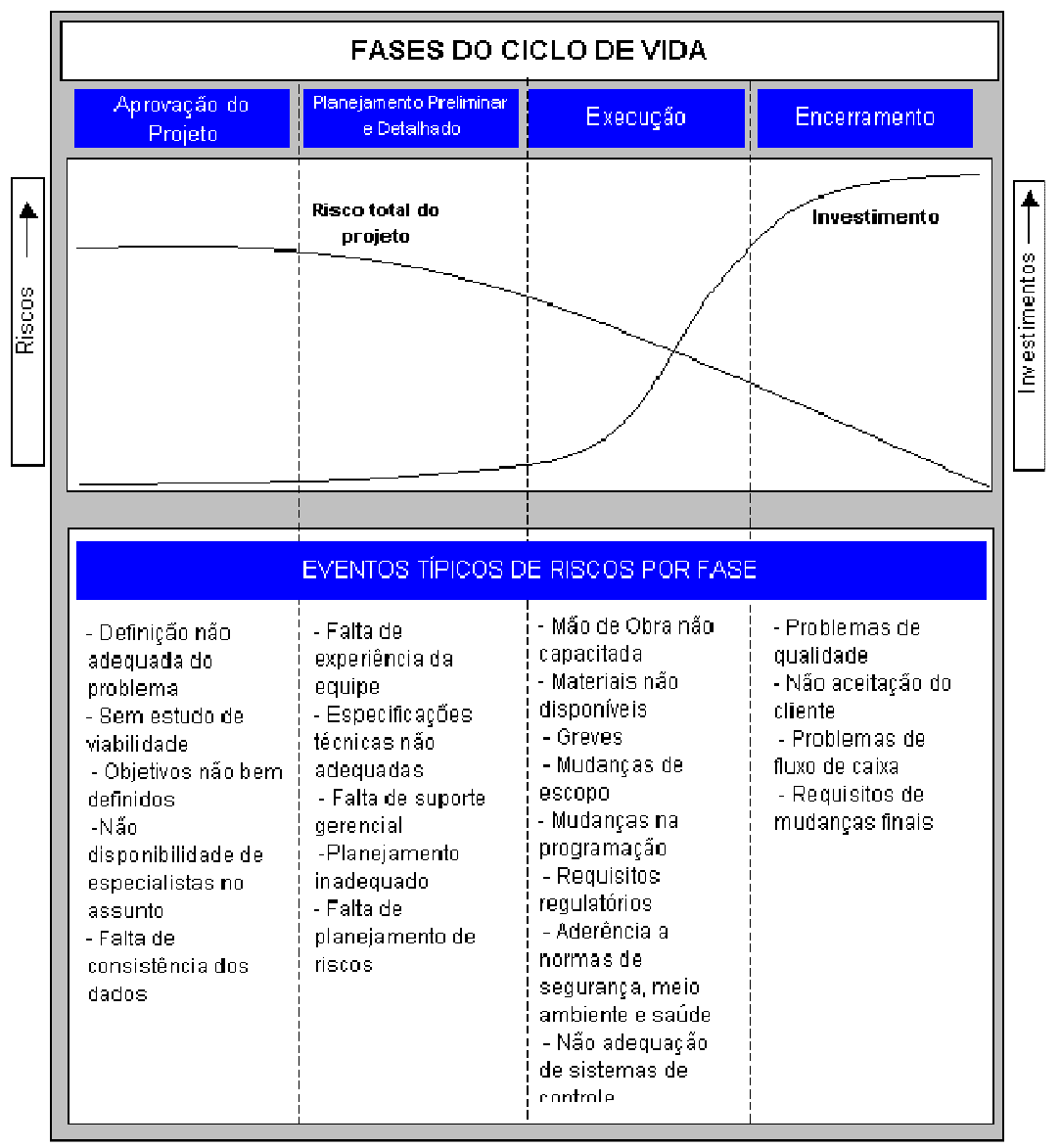

Fonte: Kerzner (2003) 
(CAGNO, E; CARON, F.; MANCINI, M., 2007) destaca a necessidade da distinção da análise de riscos nas fases de desenvolvimento onde o escopo do projeto está sendo definido, considerando o envolvimento das partes interessadas (fornecedores, clientes, usuários, etc.) com a execução do projeto onde o escopo contratual já foi definido e está congelado.

De acordo com (CLELAND; IRELAND, 2002) de modo geral, o projeto não conta com todas as informações para planejar e executar o trabalho. Um líder de projeto pode ter apenas $40 \%$ das informações necessárias, mas deve prosseguir devido aos compromissos assumidos com o cliente ou as condições de mercado.

Segundo o PMBOK (2004) a identificação de riscos é um processo iterativo porque novos riscos podem ser conhecidos conforme o projeto se desenvolve durante todo o seu ciclo de vida.

Segundo Cleland e Ireland (2002) líderes de projeto têm entre 40 e $80 \%$ das informações necessárias durante a fase de planejamento da maioria dos projetos.

\subsubsection{Abordagens para o gerenciamento de riscos}

Segundo Cleland e Ireland (2002) existe 2 abordagens básicas de gerenciamento de riscos para os projetos: Informal e Formal.

Informal: é aquela que vê o risco de maneira subjetiva, devido à natureza de sua abordagem. Muitas organizações o utilizam, mas não percebem que estão utilizando nenhum método de riscos. Uma das mais largamente utilizadas é a do fundo de contingências.

Outra informal é a discussão com expertos no assunto ou pessoas com experiências em projetos similares e incluir a visão dos riscos do projeto identificados e então ajustando o projeto de acordo para mitigar os riscos.

Formal: conjunto de procedimentos desenhados para uma organização para ser usado no processo de gerenciamento de riscos. 


\subsubsection{Organização e responsabilidades para o gerenciamento de riscos}

Segundo Kerzner (2004) embora as atividades de gerenciamento de riscos seja específica e designada para colaboradores mais do que grupos, o gerente de projetos é ainda o responsável geral pelo gerenciamento de riscos.

O projeto pode ser desenvolvido numa organização cujo gerenciamento de riscos pode ser centralizado ou descentralizado. Porém como o gerenciamento de riscos envolve atividades com responsabilidades compartilhadas por todos os membros da equipe, a organização de gerenciamento de riscos descentralizada é mais frequentemente utilizada (KERZNER, 2004).

Figura 13 - Organização e responsabilidades para o gerenciamento de riscos

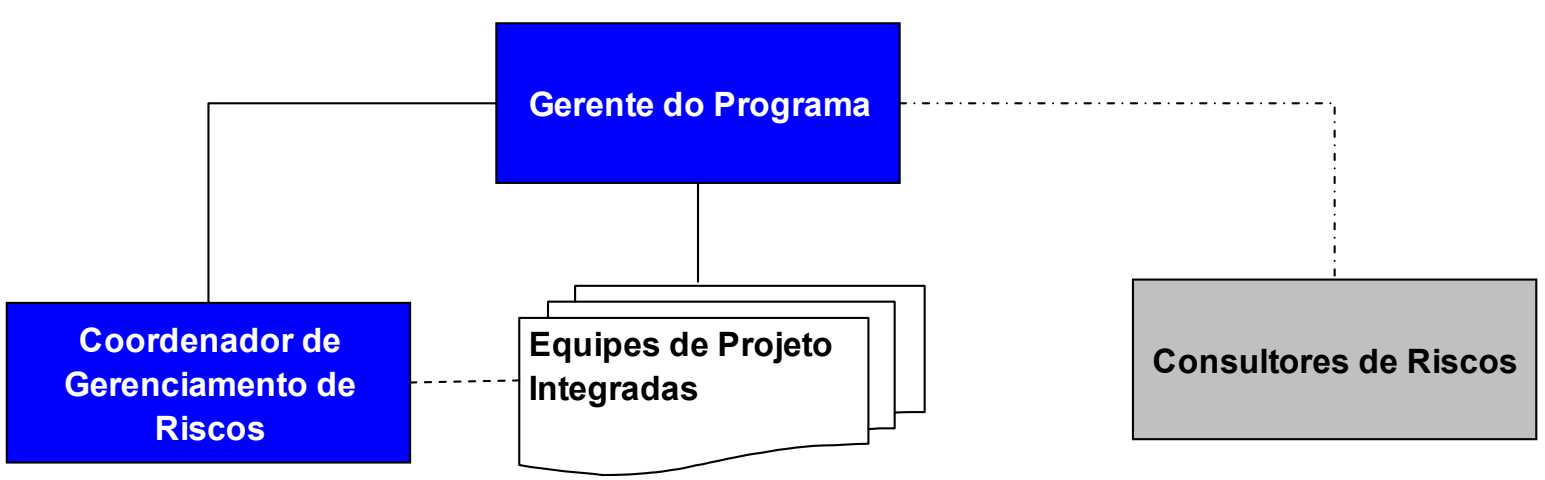

Fonte: Adaptado de Kerzner (2004)

Segundo o PMBOK (2004) as atividades de identificação de riscos pode incluir os seguintes participantes, quando adequado: gerente de projetos, membros da equipe do projeto, equipe de gerenciamento de riscos (se designada), especialistas no assunto de fora da equipe do projeto, clientes, usuários finais, outros gerentes de projetos, partes interessadas e especialistas em gerenciamento de riscos. 
O contexto organizacional da empresa segundo AS/NZS 4360 (2004) ajuda no entendimento da organização, suas capacidades e metas, objetivos e estratégias. De acordo com a norma o contexto organizacional é importante por que:

- Gerenciamento de riscos ocorre dentro do contexto de alcançar as metas e objetivos do projeto;

- Falhas em alcançar os objetivos é um dos riscos que precisa ser gerenciado;

- As metas e estratégias ajudam a definir se um risco é aceitável ou não aceitável.

\subsubsection{Processos de gerenciamento de riscos (PMBOK)}

Os processos de gerenciamento de riscos do projeto descritos pelo PMBOK (2004) são os seguintes:

- Planejamento do gerenciamento de riscos - decisão de como abordar, planejar e executar as atividades de gerenciamento de riscos de um projeto.

- Identificação de riscos - determinação dos riscos que podem afetar o projeto e documentação de suas características.

- Análise qualitativa de riscos - priorização dos riscos para análise ou ação adicional subseqüente através de avaliação e combinação de sua probabilidade de ocorrência e impacto.

- Análise quantitativa de riscos - análise numérica do efeito dos riscos identificados nos objetivos gerais do projeto.

- Planejamento de respostas a riscos - desenvolvimento de opções e ações para aumentar as oportunidades e reduzir as ameaças aos objetivos do projeto.

- Monitoramento e controle de riscos - acompanhamento dos riscos identificados, monitoramento dos riscos residuais, identificação dos novos riscos, execução de planos de respostas a riscos e avaliação da sua eficácia durante todo o ciclo de vida do projeto. 


\section{A figura 14 mostra o detalhamento destes processos do (PMBOK, 2004) com suas entradas, ferramentas e técnicas e saídas.}

Figura 14 - Processos de gerenciamento de riscos

\begin{tabular}{|c|c|c|}
\hline \multicolumn{3}{|c|}{ GERENCIAMENTO DE RISCOS DO PROJETO } \\
\hline $\begin{array}{c}\text { Planejamento do } \\
\text { Gerenciamento de Riscos }\end{array}$ & $\begin{array}{c}\begin{array}{c}\text { Identificação } \\
\text { de Riscos }\end{array} \\
\end{array}$ & $\begin{array}{c}\text { Análise Qualitativa } \\
\text { de Riscos }\end{array}$ \\
\hline $\begin{array}{l}\text { 1. Entradas } \\
.1 \text { Fatores ambientais da empresa } \\
.2 \text { Ativos de processos } \\
\text { organizacionais } \\
.3 \text { Declaraçấo do escopo do } \\
\text { projeto } \\
.4 \text { Plano de gerenciamento do } \\
\text { projeto } \\
\text { 2. Ferramentas e técnicas } \\
1 \text { Análise e reuniốes de } \\
\text { planejamento } \\
\text { 3. Saídas } \\
1 \text { Plano de gerenciamento de } \\
\text { riscos }\end{array}$ & $\begin{array}{l}\text { 1. Entradas } \\
.1 \text { Fatores ambientais da empresa } \\
.2 \text { Ativos de processos } \\
\text { organizacionais } \\
3 \text { Declaraçấo do escopo do } \\
\text { projeto } \\
4 \text { Plano de gerenciamento de } \\
\text { riscos } \\
.5 \text { Plano de gerenciamento do } \\
\text { projeto } \\
\text { 2. Ferramentas e técnicas } \\
1 \text { Revisốes da documentaçấo } \\
.2 \text { Técnicas da coleta de } \\
\text { informaçóes } \\
3 \text { Análise da lista de verificaçốes } \\
4 \text { Análise das premissas } \\
5 \text { Técnicas com diagramas } \\
\text { 3. Saílas } \\
1 \text { Registro de riscos }\end{array}$ & $\begin{array}{l}\text { 1. Entradas } \\
1 \text { Ativos de processos } \\
\text { organizacionais } \\
.2 \text { Declaraçẫo do escopo do } \\
\text { projeto } \\
3 \text { Plano de gerenciamento de } \\
\text { riscos } \\
4 \text { Registro de riscos } \\
\text { 2. Ferramentas e técnicas } \\
1 \text { Avaliaçẫo de probabilidade e } \\
\text { impacto dos riscos } \\
.2 \text { Matriz de probabilidade e } \\
\text { impacto } \\
3 \text { Avaliaçấo da qualidade dos } \\
\text { dados sobre riscos } \\
4 \text { Categorizaçẫo de riscos } \\
5 \text { Avaliaçẫo da urgência do risco } \\
\text { 3. Saidas } \\
1 \text { Registro de riscos (atualizaçốes) }\end{array}$ \\
\hline $\begin{array}{c}\text { Análise Quantitativa } \\
\text { de Riscos }\end{array}$ & $\begin{array}{c}\text { Planejamento de Respostas } \\
\text { a Riscos }\end{array}$ & $\begin{array}{c}\text { Monitoramento e Controle de } \\
\text { Riscos }\end{array}$ \\
\hline $\begin{array}{l}\text { 1. Entradas } \\
.1 \text { Ativos de processos } \\
\text { organizacionais } \\
.2 \text { Declaraçăo do escopo do } \\
\text { projeto } \\
3 \text { Plano de gerenciamento de } \\
\text { riscos } \\
.4 \text { Registro de riscos } \\
5 \text { Plano de gerenciarnento do } \\
\text { projeto } \\
\text { - Plano de gerenciamento do } \\
\text { cronograma do projeto } \\
\text { - Plano de gerencianento de } \\
\text { custos do projeto } \\
\text { 2. Ferramentas e técnicas } \\
.1 \text { Técnicas de representaçấo e } \\
\text { coleta de dados } \\
2 \text { Análise quantitativa de riscos e } \\
\text { técnicas de modelagem } \\
\text { 3. Saídas } \\
.1 \text { Registro de riscos (atualizaçóes) }\end{array}$ & $\begin{array}{l}\text { 1. Entradlas } \\
1 \text { Plano de gerenciamento de } \\
\text { riscos } \\
.2 \text { Registro de riscos } \\
\text { 2. Ferramentas e técnicas } \\
1 \text { Estratégias para riscos } \\
\text { negativos ou ameaças } \\
.2 \text { Estratégias para riscos positivos } \\
\text { ou oportunidades } \\
.3 \text { Estratégias para ameaças e } \\
\text { oportunidades } \\
4 \text { Estratégias para respostas } \\
\text { contigenciadas } \\
\text { 3. Saídas } \\
1 \text { Registro de riscos (atualizaçốes) } \\
2 \text { Plano de gerencianento do } \\
\text { projeto (atualizaçôes) } \\
3 \text { Acordos contratuais } \\
\text { relacionados a riscos }\end{array}$ & $\begin{array}{l}\text { 1. Entradas } \\
1 \text { Plano de gerenciamento de } \\
\text { riscos } \\
.2 \text { Registro de riscos } \\
.3 \text { Solicitaçốes de mudanças } \\
\text { aprovadas } \\
.4 \text { Informaçốes sobre o } \\
\text { desernpenho do trabalho } \\
.5 \text { Relatórios de desempenho } \\
\text { 2. Ferramentas e técnicas } \\
1 \text { Reavaliaçấo de riscos } \\
.2 \text { Auditorias de riscos } \\
.3 \text { Análise das tendências e da } \\
\text { variaçấo } \\
4 \text { Mediçấo do desempenho técnico } \\
.5 \text { Análise das reservas } \\
.6 \text { Reuniốes de andamento } \\
\text { 3. Saídas } \\
1 \text { Registro de riscos (atualizaçốes) } \\
.2 \text { Mudanças solicitadas } \\
3 \text { Açốes corretivas } \\
\text { recomendadas } \\
.4 \text { Açốes preventivas } \\
\text { recomendadas } \\
.5 \text { Ativo de processos } \\
\text { organizacionais (atualizaçốes) } \\
6 \text { Plano de gerenciamento do } \\
\text { projeto (atualizaçốes) }\end{array}$ \\
\hline
\end{tabular}

Fonte: PMBOK (2004) 


\subsubsection{Processos do gerenciamento de riscos (AS/NZS 4360:2004)}

Já a AS/NZS 4360 (2004) define os passos envolvidos no gerenciamento de riscos como, estabelecer o contexto e objetivos, identificar os riscos, analisar os riscos, fazer a sua avaliação e tratamento, conforme indicado na figura 15.

Figura 15 - Passos do gerenciamento de riscos AS/NZS 4360:2004

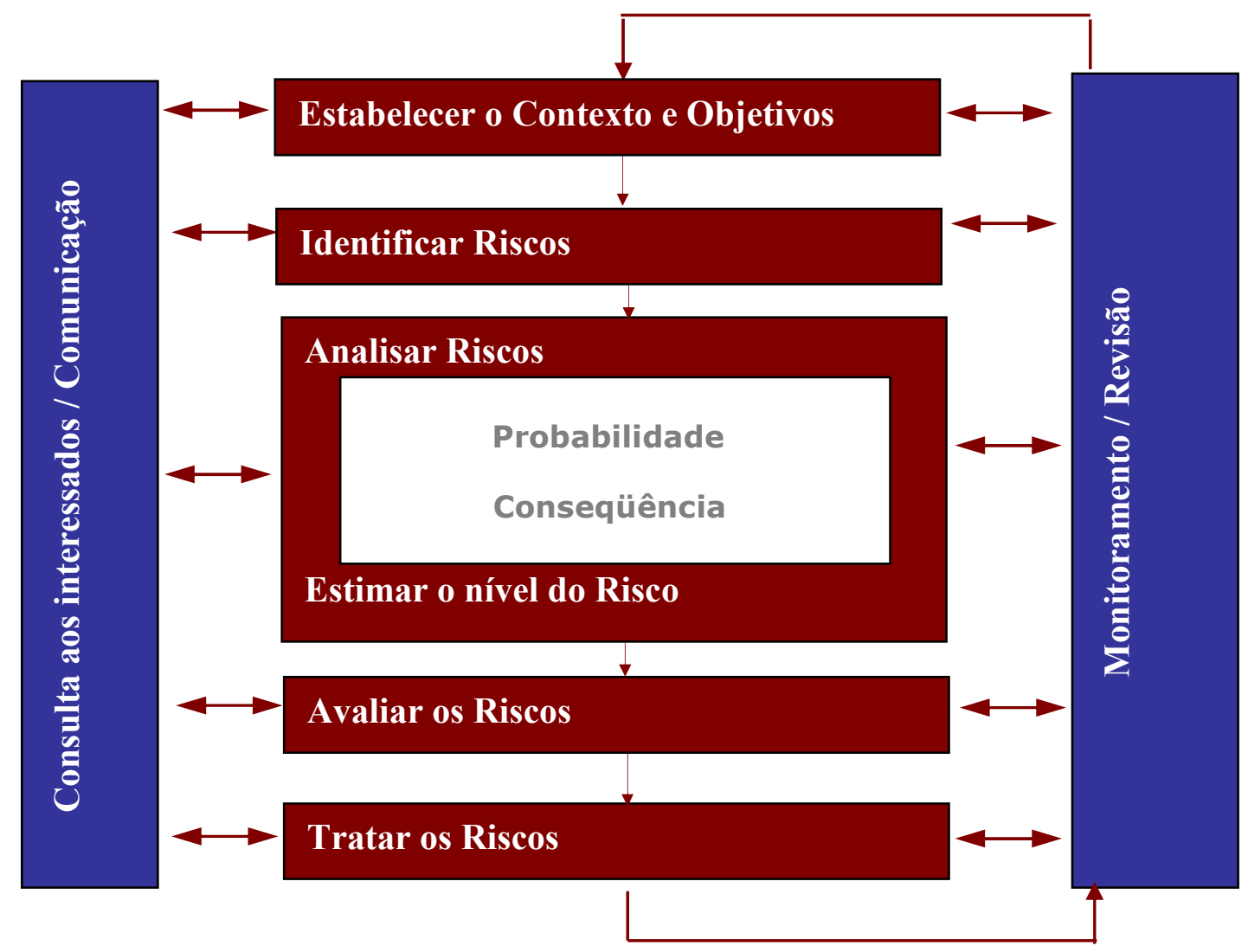

Fonte: AS/NZS 4360 (2004)

\subsubsection{Estrutura Analítica de Riscos}

Segundo Hillson apud HILLSON; GRIMALDI; RAFELE, 2006 desde que foi pela primeira vez descrita a Estrutura Analítica de Riscos (EAR) têm sido reconhecida como uma ferramenta útil na estruturação do processo de riscos e foi incluída em vários padrões e guias de gerenciamento de riscos (por exemplo, Association for Project Management, 2004; Project Management Institute, 2004). A EAR é definida em termos similares da Estrutura Analítica de Projetos (EAP), como "um grupo orientado de riscos do projeto que organiza e define a exposição total de riscos do 
projeto. Cada nível inferior da EAR representa uma definição mais detalhada das fontes de riscos do projeto" (HILLSON, 2002). A EAR é, portanto uma estrutura hierárquica das fontes de riscos potenciais do projeto. Ela pode ser usada como base para estruturar e guiar o processo de gerenciamento de riscos, da mesma forma que a EAP ajuda no processo de gerenciamento do projeto, definindo o escopo do trabalho (PMBOK, 2004). Uma EAR genérica pode ser útil, porém não incluirá todo o escopo dos possíveis riscos de cada projeto. Uma alternativa é, portanto a elaboração de uma EAR específica para um específico setor de negócios ou tipos de projetos para uma organização. Uma vez que a EAR é definida ela pode ser utilizada de diversas formas. Hillson apud HILLSON; GRIMALDI; RAFELE, 2006, destaca os principais usos e benefícios de uma EAR:

Ajuda na identificação dos riscos - servindo como guia do processo de gerenciamento de riscos e lista de verificação dos possíveis riscos de um projeto.

Análise de riscos - riscos identificados podem ser mapeados na EAR e categorizados por fontes. Isto expõe as fontes mais significativas de riscos do projeto e indica área de dependência ou correlação entre riscos. Desenvolvimento de respostas aos riscos podem então focar em área de alto risco, com respostas genéricas para as causas principais ou grupos de riscos dependentes.

Comparação de Alternativas - riscos associados com processos de contratação podem ser comparados diretamente se a mesma EAR é usada para estruturar os riscos associados a cada processo. Pode também ser utilizado como referência para estudos de avaliação de alternativas examinando-se as opções de desenvolvimento ou decisões de investimento. A exposição dos riscos em diferentes projetos dentro de um programa ou porta-fólio pode também ser diretamente comparada desde que a EAR tenha uma estrutura e terminologia comum para descrever os riscos. Isto pode ajudar o desenvolvimento de um porta-fólio referenciado com riscos.

Relatório de riscos - diferentes partes interessadas do projeto necessitam diferentes níveis de relatório de riscos e a EAR pode ser usada como fonte de informação para os vários níveis desde níveis gerenciais até os níveis das equipes do projeto. A EAR 
também ajuda na consistência da linguagem dos relatórios, reduzindo potenciais de má interpretação, especialmente quando usada para relatórios entre projetos.

Lições aprendidas para futuros projetos - Elementos de riscos de avaliações de projetos concluídos podem ser capturados usando a EAR como elemento base. Isto pode revelar riscos comuns ou genéricos, permitindo o desenvolvimento de respostas preventivas que podem ser aplicadas nos futuros projetos.

A tabela 3 mostra uma Estrutura Analítica de Riscos aplicável a projetos de engenharia.

Tabela 3 - Estrutura analítica de riscos de projetos de engenharia

\begin{tabular}{|c|c|c|}
\hline Nível 0 & Nivel 1 & Nível 2 \\
\hline \multirow[t]{35}{*}{ Riscos do projeto } & Técnico & Definição do escopo \\
\hline & & Definiçẫo dos requisitos \\
\hline & & Processos técnicos \\
\hline & & Interfaces técnicas \\
\hline & & Tecnologia \\
\hline & & Desempenho \\
\hline & & Confiabilidade \\
\hline & & Segurança \\
\hline & & Teste e aceitaçẫo \\
\hline & Gerenciamento & Gerenciamento de projeto \\
\hline & & Organizaçẫo \\
\hline & & Recursos \\
\hline & & Comunicaçẫo \\
\hline & & Informaçẫo \\
\hline & & Saúde, Segurança e Meio Ambiente \\
\hline & & Reputaçẫo \\
\hline & Comerciais & Termos e condiçốes contratuais \\
\hline & & Financiamento \\
\hline & & Garantias \\
\hline & & Termos de pagamento \\
\hline & & Suspensão e término \\
\hline & & Suprimentos interno \\
\hline & & Subcontratos \\
\hline & & Leis aplicáveis \\
\hline & & Parcerias \\
\hline & & Legislaçẫo \\
\hline & & Regulamentos \\
\hline & & Taxas de câmbio \\
\hline & & Infraestrutura \\
\hline & & Competiçẫo \\
\hline & Externos & Clima \\
\hline & & Políticos \\
\hline & & País \\
\hline & & Pressẫo de grupos organizados \\
\hline & & Força maior \\
\hline
\end{tabular}

Fonte: Adaptado de Kerzner (2004) 


\section{A tabela 4 mostra uma Estrutura Analítica de Riscos aplicável a projetos de construção.}

Tabela 4 - Estrutura analítica de riscos de projetos de construção

\begin{tabular}{|c|c|c|c|}
\hline Nivel 0 & Nivel 1 & Nivel 2 & Nivel 3 \\
\hline \multirow[t]{38}{*}{ Riscos do projeto } & Ambientais & Estatutório & Atrasos de aprovaçẫo de licenças \\
\hline & & & Mudanças de legislação \\
\hline & & & Limitaçốes ecológicas \\
\hline & & & Outros \\
\hline & Industriais & Mercado & Aumento da competiçẫo \\
\hline & & & Mudanças na demanda \\
\hline & & & Custos/disponibilidade de materiais \\
\hline & & & Outros \\
\hline & Clientes & Equipe do cliente & $\begin{array}{l}\text { Falha dos representantes do cliente em desempenhar } \\
\text { conforme o planejado }\end{array}$ \\
\hline & & & Vários pontos de contato \\
\hline & & & Responsabilidades do cliente năo bem definidas \\
\hline & & & Outros \\
\hline & & Equipe de Gerenciamento de Projetos & Controles inadequados de gerenciamento de projetos \\
\hline & & & Balanço de recursos \& experiência inadequado \\
\hline & & & $\begin{array}{l}\text { Responsabilidades da equipe de gerenciamento de } \\
\text { projetos nắo bem definidas }\end{array}$ \\
\hline & & & Outros \\
\hline & & Metas e objetivos & Objetivos do projeto năo bem definidos \\
\hline & & & $\begin{array}{l}\text { Objetivos do projeto alterando e afetando o desenho de } \\
\text { engenharia }\end{array}$ \\
\hline & & & Conflitos entre objetivos primários e secundários \\
\hline & & & Outros \\
\hline & & Fundos & Requisitos tardios de economia de custos \\
\hline & & & Recursos financeiros inadequados \\
\hline & & & $\begin{array}{l}\text { Recursos financeiros nẫo alinhado com requisitos de } \\
\text { fluxo de caixa }\end{array}$ \\
\hline & & & Outros \\
\hline & & Tática & Mudanças não oficializadas por escrito \\
\hline & & & Procedimentos de controle de mudanças nẫo aceitos \\
\hline & & & Incapacidade de cumprir marcos de engenharia \\
\hline & & & Outros \\
\hline & Projeto & Equipe & Comunicação inadequada entre a equipe \\
\hline & & & Mudanças na equipe chave \\
\hline & & & Número de recursos humanos inadequados \\
\hline & & & Outros \\
\hline & & Tática & Controle de custos \\
\hline & & & Controle de prazos \\
\hline & & & Controle de qualidade \\
\hline & & & Controle de mudanças \\
\hline & & Tarefas & Engenharia \\
\hline & & & Construçẫo \\
\hline
\end{tabular}


A tabela 5 mostra uma Estrutura Analítica de Riscos típica para os projetos da ABB.

Tabela 5 - Estrutura Analítica de riscos (EAR) típica de projetos da ABB

\begin{tabular}{|c|c|c|}
\hline Nivel 0 & Nivel 1 & Nivel 2 \\
\hline \multirow[t]{37}{*}{ Riscos do projeto } & Contratos e acordos & Penalidades e indenizaçôes contratuais \\
\hline & & Cliente deliberadamente aproveitando-se de pontos fracos no contrato \\
\hline & & Acordos contendo especificaçổes que podem causar má interpretação \\
\hline & & Linguagem contratual vaga e genérica \\
\hline & & Assuntos críticos năo concluídos, desvios técnicos e comerciais \\
\hline & & Procedimentos de controle de mudanças de escopo năo acordadas com o cliente \\
\hline & & Necessidade de relatórios excessiva requerida pelo cliente \\
\hline & & Licenças requeridas \\
\hline & & Agentes e comissôes \\
\hline & Responsabilidades e obrigaçốes & Escopo ou limites de responsabilidades não bem definidos \\
\hline & & Limites de obrigaçőes \\
\hline & & $\begin{array}{l}\text { Cancelamento causado por força maior: responsabilidades do cliente e fornecedor po } \\
\text { escopo de fornecimento, execuçăo năo de acordo com o contrato }\end{array}$ \\
\hline & Financeiros & Pagamentos, fluxos de caixa, carta de crédito, procedimentos \\
\hline & & Flutuaçốes na taxa de câmbio corrente \\
\hline & & Inflaçốes \\
\hline & & Obrigaçỗes financeiras \\
\hline & & Status financeiro - história de crédito do cliente \\
\hline & & Exposição a subcontrataçăo \\
\hline & Políticos & Estabilidade do ambiente político \\
\hline & & Distúrbios políticos causando atrasos no início das operaçôes \\
\hline & & Distúrbios políticos que poderiam inibir a entrega do desempenho esperado \\
\hline & & Mudanças na legislaçẫo \\
\hline & & Restriçoes de exportação / importaçãa \\
\hline & & Cláusulas legais de arbitragem \\
\hline & Garantias & Garantias năo padronizadas / entendidas \\
\hline & & Custos de transportes para ou da fábrica da ABB \\
\hline & & Reparos de equipamentos no local de utilização \\
\hline & & Acesso imediato aos equipamentos para reparos no local de utilizaçäo \\
\hline & Prazos & Prazos de entrega não realísticos \\
\hline & & Impacto na entrega devido a soluçổes nẫo padronizadas \\
\hline & & Comprometimento da entrega \\
\hline & & Intercâmbio de documentaçăo entre os envolvidos \\
\hline & & Procedimentos de aprowação \\
\hline & & Acesso ao local da obra e disponibilidade de utilidades \\
\hline & & Trabalhos nẫo concluídos a tempo por outras equipes \\
\hline & & Interfaces compulsórias com outros fornecedores / entregas \\
\hline & & Impacto na entrega devido a picos de recursos necessários \\
\hline
\end{tabular}




\begin{tabular}{|c|c|c|}
\hline \multirow{18}{*}{ Nível 0} & Técnicos e tecnológicos & Soluçốes de aplicaçốes não padronizadas \\
\hline & & Simulaçôes de testes ambientais \\
\hline & & Requisitos de garantia de qualidade que devem ser observados \\
\hline & & $\begin{array}{l}\text { Interfaces técnicas: manutençẫo ou ampliação de planta existente, outros fornecedores / } \\
\text { parceiros, responsabilidade de desempenho }\end{array}$ \\
\hline & & $\begin{array}{l}\text { Especficação tecnicamente vaga / descrição funcional, solução técnica ou componentes } \\
\text { selecionada pelo cliente }\end{array}$ \\
\hline & & Critérios de aceitação do cliente \\
\hline & & Contrato envolve uma grande quantidade de recursos externos \\
\hline & & Contrato envolve uma grande demanda de equipamentos de produção \\
\hline & & Mão de obra técnica de fornecimento local \\
\hline & $\begin{array}{l}\text { Fornecimento e gerenciamento da } \\
\text { demanda }\end{array}$ & Comprometimento com as entregas acordadas: ABB e terceiros \\
\hline & Clientes & Nivel de experiência do pessoal chave \\
\hline & & O nivel de prioridade do projeto \\
\hline & & Burocracia \\
\hline & & Comunicação \\
\hline & Ambientais & Emissốes (ruído, poeira, etc...) \\
\hline & & Falta/Problemas de segurança no caso de perdas ou danos em equipamentos \\
\hline & & Infraestrutura: ligações entre portos, estradas, telecomunicações, potência elétrica \\
\hline & & Questôes sócio-culturais: roubos, ética nos negócios \\
\hline
\end{tabular}

Fonte: Adaptado de Kerzner (2004)

\subsubsection{Considerações para a implantação do gerenciamento de riscos}

Segundo Conrow (2003) embora a implementação do gerenciamento de riscos varie de projeto para projeto, existem algumas considerações que são aplicáveis para todos os projetos:

- Deve-se dar uma atenção especial para os aspectos organizacionais e comportamentais. Papéis e responsabilidades para o gerenciamento de riscos dentro da organização devem ser claramente definidos e não conflitantes e o ambiente deve ser propício de maneira a permitir a prática do gerenciamento de riscos de forma ampla;

- O gerenciamento de riscos deve ser executado através do projeto dos níveis gerenciais para baixo e vice-versa. A alta administração deve dar o exemplo 
participando de forma pró-ativa e contribuindo no processo de gerenciamento de riscos, da mesma forma todas as equipes técnicas multidisciplinares devem participar principalmente na fase de identificação dos riscos;

- Deve-se identificar e utilizar motivadores simples, porém efetivos para o reconhecimento das boas práticas de gerenciamento de riscos dentro do projeto;

- O gerenciamento de riscos deve ser adaptado para cada projeto.

Segundo o PMBOK (2004) o planejamento cuidadoso e explícito aumenta a possibilidade de sucesso dos outros cinco processos de gerenciamento de riscos. $\mathrm{O}$ planejamento do gerenciamento de riscos é o processo de decidir como abordar e executar as atividades de gerenciamento de riscos de um projeto. O planejamento dos processos de gerenciamento de riscos é importante para garantir que o nível, tipo e visibilidade do gerenciamento de riscos estejam de acordo com o risco e a importância do projeto em relação à organização, para fornecer tempo e recursos suficientes para as atividades de gerenciamento de riscos e para estabelecer uma base acordada de avaliação de riscos.

\subsubsection{Condições para o sucesso da implantação}

(CONROW, 2003) cita algumas características para o sucesso de um processo de gerenciamento de riscos:

- A presença de todos os passos;

- A execução dos passos na ordem correta;

- Dar a mesma importância para todos os passos;

- A boa estruturação de cada passo do processo;

- A interatividade dos processos;

- O processo ser contínuo;

- O processo ser iniciado ainda nas fases preliminares do projeto;

- O processo ser atualizado para cada fase do projeto.

O sucesso da descrição dos riscos segundo a FERMA (2002) centra-se na apresentação dos riscos identificados num formato estruturado. A tabela 6 mostra um exemplo de descrição dos riscos. A utilização de uma estrutura bem concebida é 
necessária para garantir um processo abrangente de identificação, descrição e avaliação de riscos.

Tabela 6 - Formato estruturado de descrição de um risco

\begin{tabular}{|c|c|}
\hline Designaçäo do Risco & Descriçäo \\
\hline Âmbito do risco & Descriçẫo qualitativa de acontecimentos, como dimensẫo, tipo, número e dependências \\
\hline Natureza do risco & Ex. estratégicos, financeiros, operacionais, de conhecimento ou conformidade \\
\hline Intervenientes & Intervenientes e respectivas expectativas \\
\hline Quantificaçẫo do risco & Importância/relevância e probabilidade \\
\hline Tolerância para o risco & $\begin{array}{l}\text { Potencial de perda e impacto financeiro do risco / valor em risco / probabilidade e dimensẫo } \\
\text { de perdas } x \text { ganhos potenciais / objetivo do controle do risco e nivel de desempenho } \\
\text { pretendido }\end{array}$ \\
\hline $\begin{array}{l}\text { Tratamento e mecanismos de controle do } \\
\text { risco }\end{array}$ & $\begin{array}{l}\text { Principais meios através dos quais o risco é atualmente gerido / niveis de confiança do } \\
\text { controle existente / identificaçẫo dos protocolos de monitoramento e revisẫo }\end{array}$ \\
\hline Possiveis açốes de melhoria & Recomendaçỗes para reduçẫo do risco \\
\hline Desenvolvimento de estratégias e políticas & Identificaçẫo da funçẫo responsável pelo desenvolvimento de estratégias e políticas \\
\hline
\end{tabular}

Fonte: FERMA - Federation of European Risk Management Associations (2002)

Segundo Kerzner (2004) uma boa maneira de medir como o processo de gerenciamento de riscos está sendo efetivo é simplesmente avaliar quantos problemas que estão afetando o projeto foram identificados como riscos pela equipe de projeto. Se a resposta for menos de $50 \%$, então o seu gerenciamento está mais para crise do que estruturado.

Uma das grandes vantagens da metodologia de gerenciamento de projetos destaca (KERZNER, 2004) é que ela fornece subsídios para os processos de gerenciamento de riscos, de maneira a instruir as equipes de projeto de como trabalhar com 0 gerenciamento de riscos. 


\subsection{PROCESSOS DE AQUISIÇÃO DE BENS E SERVIÇOS}

O gerenciamento de aquisições de bens e serviços e em especial para os projetos de bens de capital representa segundo HENRIE; HEDGEPETH (2006) uma importante área para o sucesso dos projetos.

Normalmente os bens e serviços, segundo Ferrari (2006) são fornecidos por organizações externas, as quais a organização empreendedora não possui um controle direto, requerendo a utilização efetiva de um planejamento das aquisições, instrumentos e gestão contratuais para mitigação dos riscos.

Os riscos envolvidos nos processos de aquisição segundo Zsidisin (2001) podem afetar significativamente o sucesso financeiro das organizações.

\subsubsection{Definição do Gerenciamento de Aquisições}

(KERZNER, 2003) define as aquisições como um processo que envolve duas partes com diferentes objetivos as quais interagem num determinado segmento do mercado.

Sendo que para (KERZNER, 2003) tipicamente os ciclos da aquisição envolvem:

- Ciclo dos requisitos: definições dos requisitos da aquisição

- Ciclo da requisição: análise das fontes e produção dos documentos para contratação

- Ciclo da solicitação: o processo de negociação

- Ciclo da contratação: seleção do fornecedor e aprovação do contrato

- Ciclo da administração do contrato: gerenciamento do contrato até o encerramento do contrato

O gerenciamento de aquisições do projeto segundo o PMBOK (2004) inclui os processos para comprar ou adquirir os produtos, serviços ou resultados necessários de fora da equipe do projeto para realizar o trabalho. A perspectiva desta aquisição pode ser da organização como comprador ou fornecedor. 
Os processos de gerenciamento de aquisições do projeto de acordo com o (PMBOK, 2004) e de forma similar a (KERZNER, 2003), porém com uma nomenclatura um pouco diferente inclui:

- Planejar compras e aquisições - determinação do que comprar ou adquirir e de quando e como fazer isso.

- Planejar contratações - documentação dos requisitos de produtos, serviços e resultados e identificação de possíveis fornecedores.

- Solicitar respostas de fornecedores - obtenção de informações, cotações, preços, ofertas ou propostas, conforme adequado.

- Selecionar fornecedores - análise de ofertas e escolha entre possíveis fornecedores e negociação de um contrato por escrito com cada fornecedor.

- Administração de contrato - gerenciamento do contrato e da relação entre o comprador e o fornecedor, análise e documentação do desempenho atual ou passado de um fornecedor a fim de estabelecer ações corretivas necessárias e fornecer uma base para futuras relações com o fornecedor, gerenciamento de mudanças relacionadas ao contrato e, quando adequado, gerenciamento da relação contratual com o comprador externo do projeto.

- Encerramento do contrato - terminar e liquidar cada contrato, inclusive a resolução de quaisquer itens em aberto, e encerrar cada contrato aplicável ao projeto ou a uma fase do projeto.

A Figura 16 fornece uma visão geral dos processos de gerenciamento de aquisições do projeto de acordo com o (PMBOK, 2004). 
Figura 16 - Processos de gerenciamento de aquisições do projeto do PMBOK

\section{GERENCIAMENTO DE AQUISIÇÕES DO PROJETO}

\begin{tabular}{||c||}
\hline \multicolumn{1}{|c|}{ Planejar Compras } \\
e Aquisiçöes
\end{tabular}

\begin{tabular}{|c|}
\hline Planejar Contrataçőes \\
\hline $\begin{array}{l}\text { 1. Entradas } \\
.1 \text { Plano de gerenciamento das } \\
\text { aquisiçốes } \\
.2 \text { Declaração de trabalho do } \\
\text { contrato } \\
3 \text { Decisôes de fazer ou comprar } \\
.4 \text { Estrutura analtica do projeto } \\
5 \text { Plano de gerenciamento do } \\
\text { projeto } \\
\text { - Registro de riscos } \\
\text { - Acordos contratuais } \\
\text { relacionados a riscos } \\
\text { - Recursos necessários } \\
\text { - Cronograna do projeto } \\
\text { - Estimativas de custos da } \\
\text { atividade } \\
\text { - Linha de base dos custos } \\
\text { 2. Ferramentas e técnicas } \\
1 \text { Formulário padrẫo } \\
.2 \text { Opiniấo especializada } \\
\text { 3. Saidas } \\
.1 \text { Documentos de aquisiçẫo } \\
2 \text { Critérios de avaliaçấo } \\
3 \text { Declaraçấo de trabalho do } \\
\text { contrato (atualizaçóes) }\end{array}$ \\
\hline
\end{tabular}

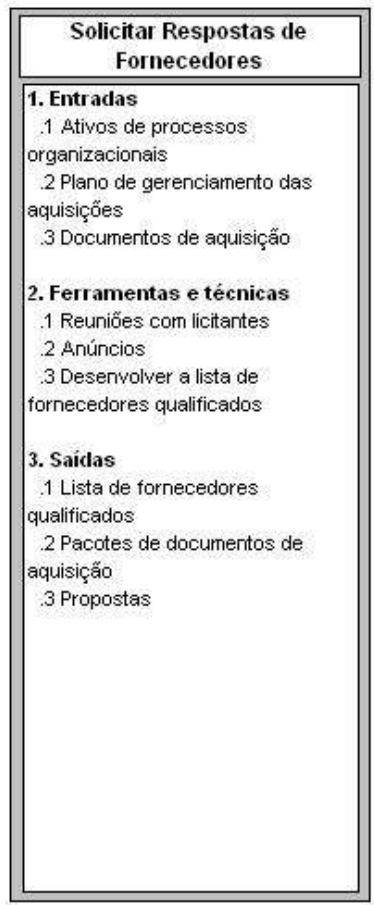

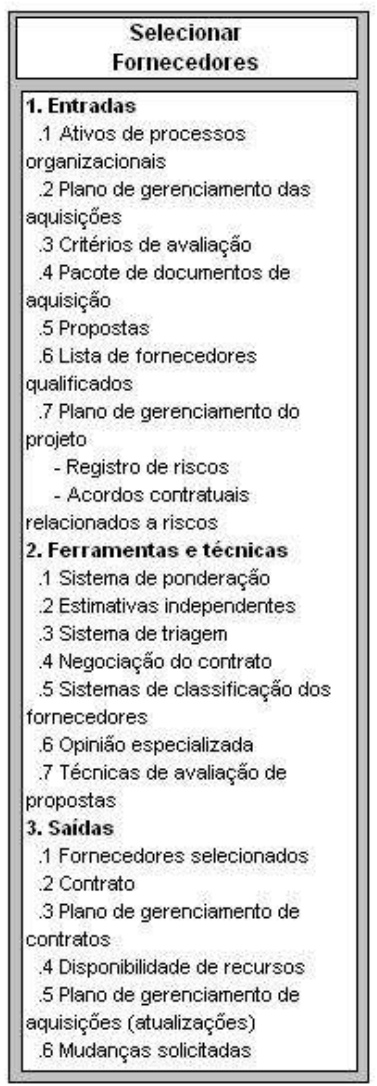

\begin{tabular}{|c|}
\hline $\begin{array}{l}\text { Administração } \\
\text { do Contrato }\end{array}$ \\
\hline 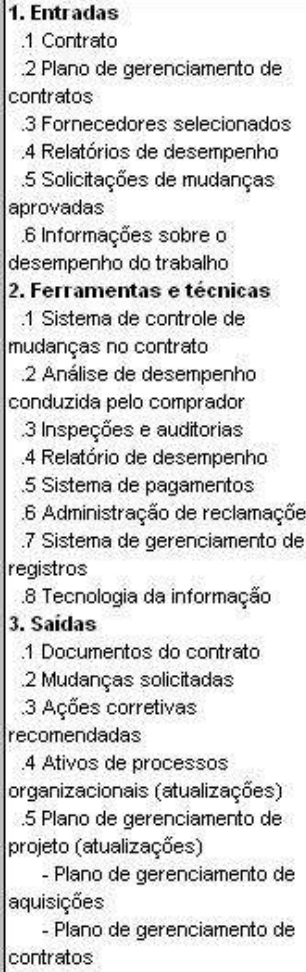 \\
\hline
\end{tabular}

\begin{tabular}{|c|}
\hline $\begin{array}{c}\text { Encerramento } \\
\text { do Contrato }\end{array}$ \\
\hline $\begin{array}{l}\text { 1. Entradas } \\
.1 \text { Plano de gerenciamento de } \\
\text { aquisiçốes } \\
.2 \text { Plano de gerenciamento de } \\
\text { contratos } \\
.3 \text { Documentaçẫo do contrato } \\
.4 \text { Procedimento de encerramento } \\
\text { de contratos } \\
\text { 2. Ferramentas e técnicas } \\
.1 \text { Auditorias de aquisiçẫo } \\
.2 \text { Sistema de gerenciamento de } \\
\text { registros } \\
\text { 3. Saídas } \\
.1 \text { Contratos encerrados } \\
2 \text { Ativos de processos } \\
\text { organizacionais (atualizaçóes) }\end{array}$ \\
\hline
\end{tabular}


Neste estudo é utilizado como referência os processos de aquisições definidos pelo PMBOK 2004, por ser amplamente divulgado e conhecido na comunidade de gerenciamento de projetos, analisando dentro de cada processo os conceitos referenciados.

\subsubsection{Planejar compras e aquisições}

O planejamento de compras e aquisições do projeto gera como subproduto o plano de gerenciamento das aquisições o qual é um dos produtos do plano de gerenciamento do projeto (PMBOK, 2004).

Como tipicamente para os projetos de bens de capital os equipamentos, materiais e serviços em geral são obtidos fora da organização executora, neste caso segundo (PMBOK, 2004) os processos de planejar compras e aquisições até encerramento do contrato deveriam ser executados para cada item a ser comprado ou adquirido.

A definição do número de itens a ser comprado ou adquirido em um projeto é parte das discussões estratégicas do projeto e envolve várias dimensões desde aspectos tecnológicos, objetivos e restrições do projeto, experiência da organização empreendedora, mercado fornecedor, aspectos políticos dentre outros.

As estratégias de planejar compras e aquisições segundo o PMBOK (2004) estão totalmente integradas com as outras áreas de gerenciamento do projeto, podendo ser influenciada por elas, especialmente através do cronograma e riscos do projeto, bem como influenciá-las requisitando análises ou solicitações de mudanças com o objetivo de mitigar possíveis riscos ou maximizar oportunidades.

Para o planejamento das compras e aquisições segundo Kovács (2004) é importante o conhecimento do ambiente externo e interno a organização empreendedora. $O$ ambiente externo através de seus fatores sócio, econômicos e políticos, bem como a situação do mercado fornecedor e o ambiente interno através do conhecimento dos procedimentos e normas corporativas internas para a aquisição de bens e serviços, bem como as questões organizacionais da empresa. 
Como a maioria das aquisições de bens e serviços para os projetos de bens de capital, envolve normalmente itens feitos sob encomenda para atender os requisitos do projeto, o escopo dos bens e serviços é desenvolvido em fases requerendo estratégias adequadas de aquisições para o nível de qualidade esperado de abordagem ao mercado.

(KOVÁCS, 2004) destaca a importância do envolvimento da equipe de aquisições já nas fases de desenvolvimento dos projetos. O envolvimento antecipado dos fornecedores nas fases de desenvolvimento do projeto e planejamento das compras e aquisições pode ajudar a mitigar os riscos de uma contratação. O (DOD/DEFENSE ACQUISITIONS UNIVERSITY, 2003), por exemplo, descreve o relacionamento entre o governo e contratados para o gerenciamento de riscos, dando ênfase ao envolvimento com o contratado ainda nas fases de desenvolvimento dos programas de maneira que uma análise de riscos efetiva possa ser realizada, uma vez que os contratados conhecem melhor os riscos técnicos do que o governo. Juntos governo e contratados trocam informações, compreendem os riscos envolvidos e desenvolvem e executam ações de gerenciamento. Entretanto é necessário sempre que possível manter o ambiente competitivo, para obtenção de bens e serviços a preços justos e condizentes com o mercado.

Nos projetos de bens de capital sendo executado através de contratação externa segundo CIDB (2004) um número maior de partes está envolvido com os riscos, sendo os principais:
○ o contratante
- o contratado (e subcontratado)
- os fornecedores de serviços

A alocação da responsabilidade entre as várias partes envolvidas nos riscos de um projeto segundo Kerzner (2003) é um aspecto importante do gerenciamento de riscos.

(KERZNER, 2004) menciona que o gerenciamento de riscos adquire grande importância para organizações de projetos à medida que seus clientes cada vez 
mais estruturados no nível do gerenciamento de projetos começam a demandar cada vez mais novos projetos e muitos deles no regime de empreitada global. Sendo os contratados agora responsáveis pela instalação bem como o comissionamento e partida e em alguns casos até a prestação de serviços pós- partida. Muitas vezes estes contratos são de clientes ainda não muito experimentados em gerenciamento de riscos, ficando nestes casos $100 \%$ dos riscos do projeto sob a responsabilidade dos contratados.

(CIDB, 2004) destaca a alocação típica de riscos entre as duas partes, o contratante e o contratado, comumente encontrados nas estratégias de contratação e preços conforme ilustrada na figura 17 onde pode se observar que o incentivo do contratado está diretamente ligado a sua exposição ao risco. Por outro lado, a flexibilidade do contratante está relacionada à sua exposição aos riscos. Quanto maior o risco assumido pelo contratante, maior é a incerteza do custo final do projeto. Entretanto, quanto maior o risco para o contratado maior a probabilidade de receber preços altos no processo de contratação.

Figura 17 - Alocação de riscos em contratos de engenharia e construção

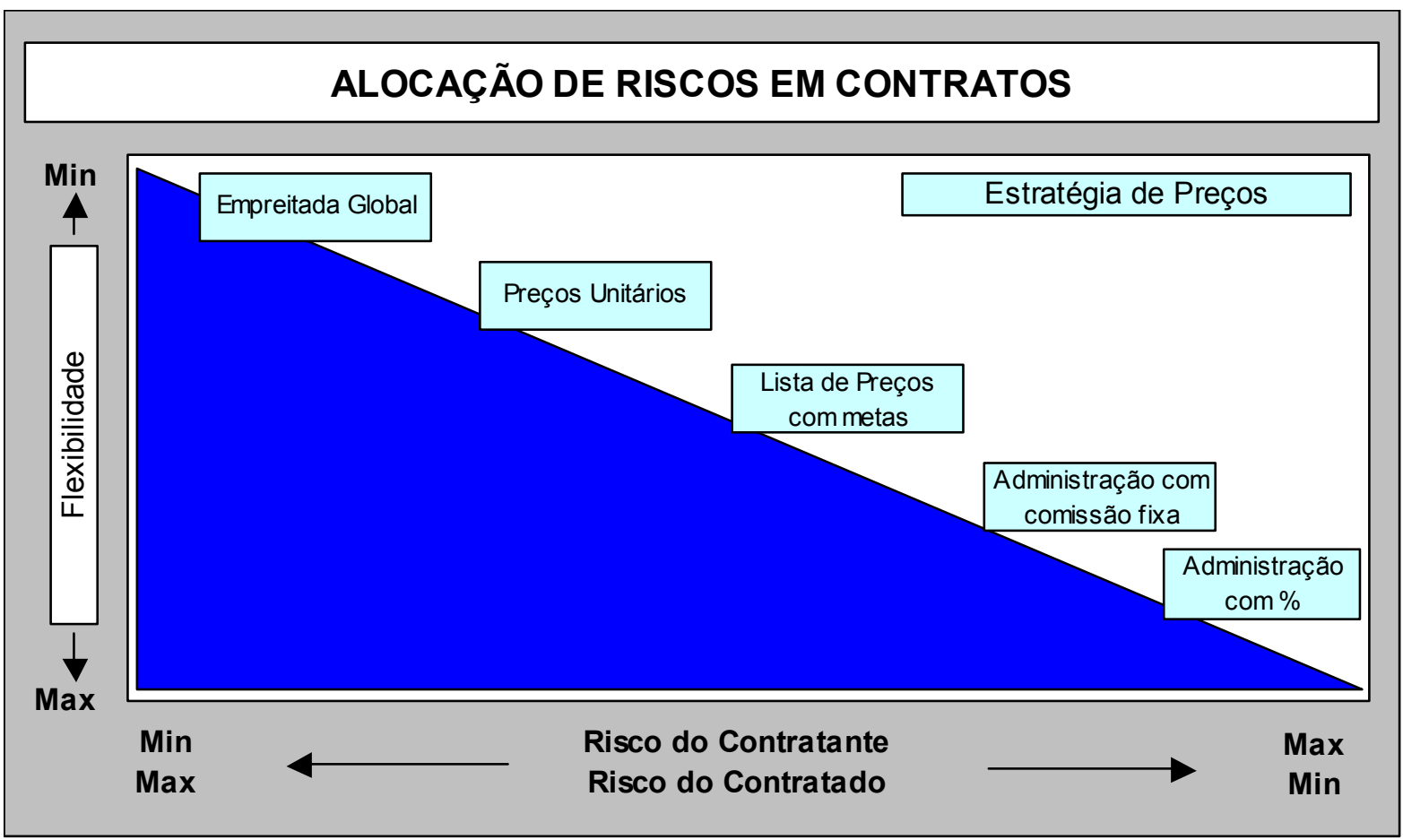

Fonte: Adaptado de CIDB (2004) 
Segundo o CIDB (2004) todo o projeto de bens de capital está sujeito a riscos os quais podem afetar o término com sucesso dos projetos. Estes riscos podem influenciar a entrega de um projeto com relação aos prazos, custos e qualidade.

As fontes gerais de riscos em tais projetos segundo o CIDB (2004) incluem itens comerciais e de relacionamento legais, circunstâncias econômicas, comportamento humano, eventos naturais, circunstâncias políticas, problemas técnicos e tecnológicos, atividades de gerenciamento e controle e atividades individuais.

Idealmente, destaca o $(\mathrm{CIDB}, 2004)$ a responsabilidade pela indenização das conseqüências de um risco deveria ficar com aquela parte que tem controle sobre aquele risco. Na prática, entretanto pode ser preferível que a responsabilidade fique com aquela parte que seja mais capaz de gerenciar aquele risco.

Segundo Kerzner (2003) o compartilhamento dos riscos e os requisitos para as indenizações, seguros de suporte, dinheiro de retenção, etc. deve ser definido no contrato. Condições padrões de contrato, suplementados por condições específicas de contrato, normalmente fazem esta função nas empresas.

Desta forma a escolha da estratégia de contratação e preços permite o contratante passar os riscos para o contratado em troca de custo adicional.

De acordo com o Construction Risks (2007) poucos segmentos da indústria possuem os riscos da indústria da construção. A habilidade das empresas de construção de efetivamente identificar, quantificar e controlar seus riscos é uma tarefa formidável no dia a dia. Uma lista sugerida de riscos da indústria da construção está delineada na tabela 7, nas categorias: financeira, contratual, operacional, organizacional e seguro. 
Tabela 7 - Riscos da indústria da construção

\begin{tabular}{|c|c|c|}
\hline Nível 0 & Nível 1 & Nivel 2 \\
\hline \multirow[t]{39}{*}{ Riscos do projeto } & Riscos Financeiros & Financiamento do Projeto \\
\hline & & Custos de mão de Obra e Material \\
\hline & & Ganhos de volatilidade \\
\hline & & Flutuaçẫo da moeda corrente \\
\hline & & Mudanças nas taxas de juros \\
\hline & & Flutuaçẫo nos preços dos commodities \\
\hline & & Exposiçẫo regulatória \\
\hline & & Riscos de Fundos \\
\hline & & Opçỗes de açốes para os empregados \\
\hline & Riscos Contratuais & Obrigaçỗes contratuais \\
\hline & & Indenizaçỗes \\
\hline & & Formas de indenizaçốes \\
\hline & & Responsabilidades de engenharia \\
\hline & & Garantias \\
\hline & & Concessão de sub-rogação \\
\hline & & Cláusulas de danos punitivos e consequenciais / liquidação \\
\hline & & Cláusulas de força maior \\
\hline & & Subcontratados \\
\hline & Riscos Operacionais & Riscos de falhas operacionais \\
\hline & & Defeitos de construção \\
\hline & & Volatilidade do Clima \\
\hline & & Riscos políticos \\
\hline & & Riscos de Imagem \\
\hline & & Riscos regulatórios \\
\hline & & Riscos operacionais \\
\hline & & Riscos de preços de material e mão de obra \\
\hline & Riscos das formas de contratação & Contratos gerais de construçẫo \\
\hline & & Contratos \\
\hline & & Contratos de empreitada global \\
\hline & & Contratos de gerenciamento da construção \\
\hline & & Contratos de fases em paralelo \\
\hline & & Contratos de parcerias \\
\hline & Riscos com potencial de Seguro & Compensação dos empregados e obrigaçốes do empregador \\
\hline & & Obrigaçôes comerciais gerais \\
\hline & & Obrigaçôes profissionais \\
\hline & & Obrigações ambientais \\
\hline & & Obrigaçôes de categorias profissionais \\
\hline & & Obrigaçôes com sindicatos \\
\hline & & Obrigaçỗes padrỗes com sub-contratados \\
\hline
\end{tabular}

Fonte: Adaptado do C-Risks (2007)

Um importante instrumento do processo de planejar compras e aquisições segundo Kerzner (2003) é a definição do tipo de contrato planejado para ser usado em 
relação à mitigação de riscos e à transferência de riscos para o fornecedor. A tabela 8 abaixo mostra os principais tipos de contratos e suas vantagens e desvantagens.

Tabela 8 - Tipos de contratos

\begin{tabular}{|c|c|c|}
\hline Tipo de Contrato & Vantagens & Disvantagens \\
\hline \multirow{6}{*}{ Por Administração } & Fornece máxima flexibilidade para o contratante & Não garantia de custos finais \\
\hline & Minimiza o lucro do contratado & $\begin{array}{l}\text { Nẫo incentivos financeiros para minimizar } \\
\text { custos e prazos }\end{array}$ \\
\hline & $\begin{array}{l}\text { Minimiza negociaçốes e custos de } \\
\text { especificaçổes preliminares }\end{array}$ & $\begin{array}{l}\text { Permite muitas mudanças de escopo pelo } \\
\text { contratante aumentando custos e prazos }\end{array}$ \\
\hline & Permite início rápido e conclusẫo antecipada & $\begin{array}{l}\text { Permite especificaçốes pelo contratante de } \\
\text { altos custos }\end{array}$ \\
\hline & $\begin{array}{l}\text { Permite a escolha de melhores contratados ao } \\
\text { invés menor preço }\end{array}$ & \\
\hline & $\begin{array}{l}\text { Permite o uso do mesmo contratado da fase } \\
\text { inicial até término, usualmente melhorando a } \\
\text { qualidade e eficiência }\end{array}$ & \\
\hline \multirow{5}{*}{$\begin{array}{l}\text { Preço Máximo Garantido com } \\
\text { divisão de economia gerada }\end{array}$} & $\begin{array}{l}\text { Fornece garantia do custo final na data mais } \\
\text { cedo possivel }\end{array}$ & $\begin{array}{l}\text { Requer uma auditoria intensiva pela equipe } \\
\text { do contratante }\end{array}$ \\
\hline & $\begin{array}{l}\text { Garante a sinalização para o contratante de } \\
\text { atrasos e custos extras resultantes de mudanças } \\
\text { de escopo }\end{array}$ & $\begin{array}{l}\text { Requer a conclusão da engenharia } \\
\text { detalhada antes da negociaçẫo do contrato }\end{array}$ \\
\hline & Fornece incentivos para conclusão mais rápida & \\
\hline & $\begin{array}{l}\text { Contratante e contratado compartilham os riscos } \\
\text { financeiros e tem mútuos incentivos por } \\
\text { potenciais economias }\end{array}$ & \\
\hline & $\begin{array}{l}\text { Tipo de contrato ideal para estabelecer uma } \\
\text { cooperaçẫo entre ambas as partes durante a } \\
\text { execuçẫo do projeto }\end{array}$ & \\
\hline \multirow{5}{*}{$\begin{array}{l}\text { Preço Fixo / Empreitada } \\
\text { Global }\end{array}$} & Fornece garantia do custo final & $\begin{array}{l}\text { Requer um conhecimento preciso do que se } \\
\text { quer antes do processo de contrataçấo }\end{array}$ \\
\hline & $\begin{array}{l}\text { Garante a sinalizaçẫo para o contratante de } \\
\text { atrasos e custos extras resultantes de mudanças } \\
\text { de escopo }\end{array}$ & $\begin{array}{l}\text { Requer prazos e custos elevados para o } \\
\text { desenvolvimento de especificaçốes e } \\
\text { processo de contrataçẫo. Atrasa a } \\
\text { conclusẫo do trabalho de } 3 \text { a } 4 \text { meses. }\end{array}$ \\
\hline & $\begin{array}{l}\text { Requer mínimo esforço do contratante de } \\
\text { acompanhamento do trabalho }\end{array}$ & $\begin{array}{l}\text { Custos elevados do processo de } \\
\text { contrataçấo e riscos podem reduzir número } \\
\text { de contratantes qualificados }\end{array}$ \\
\hline & $\begin{array}{l}\text { Fornece o máximo incentivo para mais rápida } \\
\text { conclusẫo no mais baixo custo }\end{array}$ & $\begin{array}{l}\text { Custos das propostas podem aumentar } \\
\text { devido ao número excessivo de } \\
\text { contingências para atender os riscos } \\
\text { envolvidos no trabalho }\end{array}$ \\
\hline & $\begin{array}{l}\text { Requer uma auditoria mínima pela equipe do } \\
\text { contratante }\end{array}$ & \\
\hline
\end{tabular}

Fonte: Adaptado de (Kerzner, 2003)

O plano de gerenciamento de aquisições descreve como os processos de aquisição serão gerenciados desde o desenvolvimento da documentação de aquisição até o encerramento do contrato (PMBOK, 2004). 
Este plano de gerenciamento das aquisições pode conter dentre outros itens:

- Premissas de aquisições

- Restrições de aquisições

- Estratégias de contratação para equipamentos e materiais

- Estratégias de contratação para serviços

- Planejamento tributário

- Condições contratuais

- Critérios de pré-qualificação de fornecedores

- Processo de aquisições

- Matriz de responsabilidades

- Organização de compras

- Gestão da comunicação das aquisições

- Programação dos pacotes de contratação

- Minutas contratuais padrão

\subsubsection{Planejar contratações}

O processo de planejamento das contratações segundo o PMBOK (2004) é aquele que prepara os documentos necessários para dar suporte ao processo de aquisição dos bens ou serviços do projeto. Ele envolve a descrição para o mercado dos requisitos da descrição do trabalho e das estratégias estabelecidas no plano de gerenciamento das aquisições. O objetivo principal deste processo é a elaboração e validação do documento de aquisição.

Este documento de aquisição destaca Kerzner (2003) deve ser o desdobramento das necessidades do projeto e deve representar a maneira na qual a organização empreendedora pretende se relacionar com o mercado na busca e seleção do melhor fornecedor e posteriormente manter um relacionamento contínuo até o término do contrato com este fornecedor selecionado para atendimento dos objetivos do projeto. Percebe-se, portanto a importância do documento de aquisição para o sucesso do projeto. 
A complexidade e o nível de detalhes dos documentos de aquisição de acordo com o PMBOK (2004) devem estar de acordo com o valor da compra ou aquisição planejada e com os riscos associados a ela.

Para que o documento de aquisição represente efetivamente as necessidades do projeto, faz-se necessário ter os documentos do projeto atualizados em mãos. $\mathrm{O}$ PMBOK (2004) lista alguns dos principais documentos:

- Plano de gerenciamento das aquisições;

- Declaração do trabalho do contrato;

- Plano de gerenciamento do projeto;

- Registro de riscos do projeto;

- Acordos contratuais relacionados a riscos;

- Recursos necessários;

- Cronograma do projeto;

- Estimativas de custos da atividade;

- Linha de base dos custos.

Ferrari (2006) lembra que quando o conhecimento e a experiência requeridos para a elaboração do documento de aquisição não está disponível, torna-se importante também o envolvimento de profissionais especializados da organização empreendedora ou externos incluindo áreas de engenharia, produção, manutenção, logística, jurídico, tributário, compras, marketing, vendas, dentre outras no processo de transcrição das necessidades do projeto para o mercado.

O PMBOK (2004) menciona que a organização que realiza várias compras similares pode utilizar também de documentos de aquisição anteriores aproveitando-se inclusive das lições aprendidas dos processos de contratação. Outra prática recomendada segundo Kerzner (2003) é o envolvimento da equipe que executará a gestão dos contratos nesta fase de elaboração dos documentos de aquisição, mitigando riscos de não inclusão ou descrição de requisitos importantes e minimizando problemas de transição da fase de contratação e gestão dos contratos. 
Kerzner (2003) destaca que pode haver 3 tipos de especificações técnicas para o objeto da aquisição: a especificação detalhada, a especificação de desempenho e a especificação funcional. A especificação detalhada descreve em detalhes o que é para ser feito, neste caso o risco de desempenho é da organização empreendedora. A especificação de desempenho descreve as capacidades mensuráveis que o produto final deve atingir com relação a suas características operacionais, neste caso o risco de desempenho é do contratado. A especificação funcional por sua vez descreve o objetivo do objeto a ser contratado com o intuito de estimular a competição entre as propostas comerciais, buscando o custo total mais baixo para a organização empreendedora, também neste caso o risco de desempenho é do contratado.

Os documentos de aquisição segundo o PMBOK (2004) devem ser suficientemente rigorosos para garantir respostas consistentes e comparáveis, mas suficientemente flexíveis para permitir a consideração de sugestões de melhores maneiras de satisfazer os requisitos por parte de fornecedores.

Na fase de elaboração dos documentos de aquisição também são desenvolvidos os critérios de avaliação para classificar ou pontuar as propostas. Muitas vezes estes critérios definidos são incluídos como parte dos documentos de aquisição.

O critério de avaliação pode ser simplesmente o preço da aquisição (custo do item, adicionados de despesas secundárias, com entrega), quando o item estiver prontamente disponível a partir de diversos fornecedores qualificados ou pode ser detalhado através de vários outros critérios de avaliação.

Segundo o PMBOK, este detalhamento dos critérios de avaliação pode ser objetivo (por exemplo, "O gerente de projetos proposto precisa ser um Profissional de gerenciamento de projetos, $\mathrm{PMP} \AA$, certificado") ou subjetivo (por exemplo, "O gerente de projetos proposto precisa ter experiência anterior documentada com projetos semelhantes"). 
A tabela 9 exemplifica critérios de avaliação que podem também ser utilizados pelas organizações empreendedoras.

Tabela 9 - Critérios de avaliação de propostas

\begin{tabular}{|c|c|}
\hline Critérios & Descriçäo \\
\hline Entendimento da necessidade & A proposta do fornecedor aborda satisfatoriamente a declaraçẫo do trabalho do contrato? \\
\hline Custo total ou do ciclo de vida & O fornecedor selecionado produzirá o menor custo total (custo de compra mais custo operacional)? \\
\hline Capacidade técnica & O fornecedor possui, ou é razoável esperar que ele adquira as habilidades e conhecimentos técnicos necessários? \\
\hline Abordagem técnica & $\begin{array}{l}\text { As soluções, serviços, técnicas e metodologias técnicas propostos do fornecedor atendem aos requisitos da } \\
\text { documentaçẫo de aquisiçẫo ou provavelmente fornecerẫo mais que os resultados esperados? }\end{array}$ \\
\hline Capacidade financeira & O fornecedor possui, ou é razoável esperar que ele obtenha, os recursos financeiros necessários? \\
\hline Interesse e capacidade de produçäo & O fornecedor tem interesse e capacidade para atender aos possiveis requisitos futuros? \\
\hline Tamanho e tipo do negócio & $\begin{array}{l}\text { A empresa do fornecedor atende a um tipo ou tamanho especifico de negócios conforme definido pelo comprador } \\
\text { ou estabelecido por agências governamentais e definido como condiçẫo para a concessẫo de um contrato? }\end{array}$ \\
\hline Referências & $\begin{array}{l}\text { O fornecedor pode fornecer referências de clientes anteriores que confirmem sua experiência de trabalho e sua } \\
\text { conformidade com os requisitos contratuais? }\end{array}$ \\
\hline Direitos de propriedade intelectual & $\begin{array}{l}\text { O fornecedor reivindica direitos de propriedade intelectual nos serviços ou processos de trabalho que utilizará ou } \\
\text { nos produtos que irá produzir para o projeto? }\end{array}$ \\
\hline Direitos de propriedade & $\begin{array}{l}\text { O fornecedor reivindica direitos de propriedade nos serviços ou processos de trabalho que utilizará ou nos produtos } \\
\text { que irá produzir para o projeto? }\end{array}$ \\
\hline
\end{tabular}

Fonte: Adaptado do (PMBOK, 2004)

\subsubsection{Solicitar respostas dos fornecedores}

O processo de solicitar respostas de fornecedores segundo o PMBOK (2004) obtém respostas, como cotações e propostas, de possíveis fornecedores sobre como os requisitos do projeto podem ser alcançados. Esta fase requer um grande esforço na elaboração e apresentação das propostas por parte dos fornecedores.

As organizações empreendedoras normalmente já possuem em seus bancos de dados informações de fornecedores qualificados atualizadas, inclusive em alguns casos com dados de desempenho em projetos anteriores em empresas externas e na própria organização. Quando estas informações não existem deve-se realizar o processo de qualificação específico considerando-se os critérios adequados para o objeto da aquisição. 
A lista de fornecedores qualificados nesta fase recebe então da organização empreendedora os pacotes dos documentos de aquisição para a apresentação de propostas.

Ferrari apud Ferrari (2000) destaca que o conteúdo típico dos documentos de aquisição pode incluir:

- Descrição do item de aquisição;

- Definição do escopo do fornecimento;

- Produtos intermediários mais importantes;

- Modalidade de contratação a ser utilizada no contrato;

- Cronograma macro com os eventos mais significativos;

- Definição da estrutura das propostas;

- Instruções aos proponentes;

- Minuta do contrato;

- Minuta do termo de confidencialidade;

- Carta de apresentação da solicitação;

- Normas técnicas aplicáveis;

- Regulamentações aplicáveis;

- Procedimentos técnicos e administrativos específicos do contratante;

- Modelo para a planilha de preços;

- Desenhos, esquemas e gráficos de referência.

Ainda segundo Ferrari apud Ferrari (2000) é de especial importância a descrição das instruções aos proponentes, de maneira que as propostas possam seguir as regras estabelecidas nestas orientações facilitando o processo de contratação. Estas instruções podem incluir informações como:

- Formato e conteúdo da proposta;

- Modelo da planilha de preços e quantidades;

- Identificação dos envelopes técnicos e comerciais;

- Prazo e procedimentos para esclarecimentos;

- Prazo e procedimentos para a entrega das propostas;

- Prazo de validade da proposta;

- Exigência de garantias comerciais; 
- Critérios de avaliação;

- Requisitos de confidencialidade das informações fornecidas.

As propostas são preparadas pelos fornecedores qualificados de acordo com os requisitos dos documentos de aquisição relevantes e refletem a aplicação de princípios contratuais aplicáveis. A proposta do fornecedor de acordo com o PMBOK (2004) constitui uma oferta formal e legal em resposta à solicitação do comprador. Ocasionalmente, depois que uma proposta é formalmente apresentada, o comprador solicita ao fornecedor que complemente suas propostas com uma apresentação oral com o objetivo de fornecer informações adicionais relativas à equipe proposta, à proposta de gerenciamento e à proposta técnica do fornecedor, que podem ser usadas pelo comprador na avaliação da proposta do fornecedor.

\subsubsection{Selecionar fornecedores}

O processo de seleção de fornecedores de acordo com o PMBOK (2004) envolve o recebimento de cotações ou propostas e a aplicação de critérios de avaliação, conforme aplicável, para seleção de um ou mais fornecedores que sejam qualificados e aceitáveis como um fornecedor.

O Preço ou custo segundo o PMBOK (2004) podem ser os principais determinantes para um item comercial padrão, mas o menor preço proposto talvez não seja o menor custo se o fornecedor se mostrar incapaz de fornecer os produtos, serviços ou resultados no momento oportuno.

Para a seleção de fornecedores pode se utilizar várias técnicas. Por exemplo, um sistema de ponderação pode ser usado para:

- Selecionar um único fornecedor que será solicitado a assinar um contrato padrão.

- Estabelecer uma seqüência de negociação classificando todas as propostas pela média ponderada atribuída a cada proposta. 
Segundo (Ferrari, 2006) as propostas podem variar bastante conforme o item da aquisição e o tipo de solicitação, mas geralmente possuem três partes: uma parte preliminar de qualificação, uma parte técnica e uma parte comercial.

No processo de seleção dos fornecedores, as duas partes principais envolvidas contratante e fornecedor se encontram em posições distintas com os seus dilemas próprios das suas posições. Ferrari apud Garret (2003) destaca o dilema do contratante de buscar ser bastante arrojado buscando negociar o melhor preço com o fornecedor e, portanto aumentando os riscos de fornecimento ou ter uma postura mais conservadora, protegendo-se dos riscos de fornecimento, porém podendo pagar mais do que pagaria através de uma negociação com o fornecedor.

Já do ponto de vista do fornecedor segundo Ferrari apud Garret (2003), cabe-lhe o dilema de ser agressivo na sua proposta, correndo o risco de problemas durante a execução do contrato ou ser mais conservador, garantindo uma boa margem de lucro, porém podendo perder a oportunidade devido ao ambiente competitivo.

Ferrari (2006) lembra que o processo de seleção de fornecedores está sujeito a muitas pressões, especialmente num ambiente de projeto. Sendo além das pressões típicas do ambiente de projetos de prazos e custos, podem surgir outras pressões tais como contratos corporativos com fornecedores, indicação interna de fornecedores, dos próprios fornecedores, e também as políticas organizacionais e procedimentos administrativos da organização empreendedora. Neste ambiente de pressão, atenção especial deve ser dada a definição clara dos requisitos dos documentos de aquisição e a ética na escolha dos fornecedores, de maneira a realizar processos de contratação com transparência estando a equipe de projeto preparada para a qualquer momento ser auditada com relação aos processos.

Ferrari apud Fleming (2003) destaca que em muitos projetos o gerente de projeto não tem a delegação de autoridade para contratações, sendo está autoridade delegada à área de compras, sobre a qual são tomadas várias precauções pela organização. O autor também lembra que as aquisições são um campo de muita 
exposição, sendo necessária a equipe de projeto um tratamento adequado das questões éticas que envolvem suas atividades.

Dentre os vários critérios que podem afetar a seleção das propostas, Ferrari (2006) destaca as políticas organizacionais do contratante, os aspectos mercadológicos, fatores empresariais, econômicos, financeiros, jurídicos, sociais, políticos e ambientais, podendo estes influenciar muitas das decisões de contratações dentro das empresas. O autor, também menciona aspectos de prazos internos de pagamentos, facilidades de transferência internacional, grau de tolerância a riscos, perspectivas de novos projetos, fontes de financiamento, padrão de qualidade e imagem da empresa no mercado como influenciadores na decisão de seleção das propostas.

Ferrari apud Dobler e Burt (1996) destacam da maior dificuldade da contratação de serviços quando comparado com equipamentos e materiais, os quais possuem uma descrição mais objetiva, através do uso de especificações, folha de dados, desenhos e memoriais descritivos, o que é dificultado na aquisição de serviços.

Como referência para a seleção de fornecedores e negociação, em alguns processos de contratação, pode se utilizar de estimativas de custos dos itens de aquisição, estabelecendo-se com isto um referencial. Segundo o PMBOK (2004) diferenças significativas a partir dessas estimativas de custos pode ser uma indicação de que a declaração do trabalho do contrato não era adequada, de que o possível fornecedor não entendeu corretamente ou não respondeu totalmente à declaração do trabalho do contrato, ou de que houve mudança no mercado.

A negociação do contrato de acordo com o PMBOK (2004) esclarece a estrutura e os requisitos do contrato de forma que seja possível alcançar um acordo mútuo antes da assinatura do contrato. A linguagem final do contrato reflete todos os acordos alcançados. Os assuntos tratados incluem responsabilidades e autoridades, termos e leis aplicáveis, abordagens de gerenciamento técnico e de negócios, direitos de propriedade, financiamento do contrato, solução técnica, cronograma global, pagamentos e preço. 
Cleland; Ireland (2002) chamam a atenção de que um gerente de projetos deve compreender alguns dos pontos básicos de como negociar e administrar os contratos relacionados com um projeto e em alguns casos buscar assessoria especializada.

Durante o processo de negociação Cleland; Ireland (2002) destaca a necessidade de assegurar que o contrato básico seja compreendido, assim como as cláusulas integradas ao contrato final. O autor ainda menciona a busca da limitação das obrigações legais do gerente do projeto e da organização e a compreensão de como usar as cláusulas sobre garantias, indenizações, prejuízos e danos e outras que limitem as obrigações.

Kerzner (2003) comenta que as negociações precisam ser planejadas e sugere uma lista de atividades típicas a serem discutidas e definidas para um processo de negociação tais como: definição de objetivos (posições de mínimo/máximo), avaliação do seu oponente, definição das estratégias e táticas, captura de fatos, elaboração de uma análise completa de custos/preços, definição dos fatores higiênicos (locais das negociações, quem faz o quê, etc.).

Embora os itens de negociação variem de acordo com o tipo de aquisição e as características do projeto, Ferrari apud Wangemann (2002) destaca tipicamente os seguintes itens pontos a serem negociados:

- Preços;

- Impostos;

- Condições de pagamento;

- Transporte;

- Seguros;

- Inclusões e exclusões no escopo de fornecimento;

- Recursos específicos para a realização do fornecimento.

Os processos de gerenciamento de aquisições do projeto de acordo com o PMBOK (2004) envolvem contratos que são documentos legais entre um comprador e um 
fornecedor. Um contrato é um acordo que gera obrigações para as partes que obriga o fornecedor a fornecer os produtos, serviços ou resultados especificados e obriga o comprador a fornecer compensação monetária ou outra compensação de valor. Um contrato é uma relação legal sujeita a mediação nos tribunais. O acordo pode ser simples ou complexo e pode refletir a simplicidade ou a complexidade das entregas.

Um contrato segundo o PMBOK (2004) inclui termos e condições e pode incluir outros itens como a proposta ou publicações de marketing do fornecedor e qualquer outra documentação em que o comprador esteja se baseando para estabelecer o que o fornecedor deve realizar ou fornecer. É responsabilidade da equipe de gerenciamento de projetos ajudarem a adaptar o contrato às necessidades específicas do projeto. Vale lembrar que a maior parte das organizações possui políticas e procedimentos documentados que definem especificamente quem pode assinar e administrar esses acordos em nome da organização.

Segundo o (PMBOK, 2004) é possível evitar ou mitigar alguns riscos identificáveis do projeto gerenciando ativamente o ciclo de vida do contrato e redigindo cuidadosamente os termos e as condições do contrato. Assinar um contrato de produtos ou serviços é um método de alocar a responsabilidade do gerenciamento ou de assumir riscos potenciais.

(CIDB, 2004) destaca que caso os riscos de aquisição não possam ser eliminados, mas sim gerenciados, é melhor adotar uma postura pró-ativa ao invés de uma reativa. $\mathrm{O}$ autor ainda lembra que os riscos de aquisição devem ser identificados e analisados caso a caso. Como regra geral o risco deve ser alocado para aquela parte mais capaz de gerenciá-lo de forma que o custo do risco seja o menor possível. Em muitos casos, está parte será o contratado. Transferir o risco para outra parte pode ser visto como um incentivo para a melhoria do desempenho. Entretanto, forçar uma parte a aceitar o risco o qual ela tem pouca chance de gerenciá-lo pode gerar problemas no futuro e ser não produtivo. Onde houver dúvidas com relação onde alocar o risco, o fator decisivo pode ser o custo relativo de transferi-lo ou retêlo.

Algumas formas de contrato segundo o PSC (2003) contêm procedimentos os quais são específicos para gerenciar os riscos envolvidos com os desvios de prazos e 
custos. A seleção adequada das formas de contrato faz parte integral das estratégias de gerenciamento de riscos do projeto.

Os documentos de aquisição (contratos) de acordo com o CIDB (2004) são ferramentas importantes para o gerenciamento de riscos. Contratos devem ser elaborados cuidadosamente, definindo claramente a responsabilidade das partes e com flexibilidade suficiente para lidar com possíveis mudanças. A tabela 10 mostra os principais riscos para o contratante e algumas estratégias de mitigação destes riscos.

Tabela 10 - Principais riscos e estratégias de mitigação para o contratante

\begin{tabular}{|c|c|c|c|}
\hline \multirow{2}{*}{ Riscos para o Contratante } & \multirow{2}{*}{$\begin{array}{l}\text { É o risco } \\
\text { normalmente } \\
\text { segurável? }\end{array}$} & \multicolumn{2}{|c|}{ Método usual de gerenciar o risco } \\
\hline & & Em contratos envolvendo terceiros & Em contratos diretos \\
\hline $\begin{array}{l}\text { Riscos de atrasos nos processos públicos, } \\
\text { formalidades legais, protestos por grupos } \\
\text { organizados, mudanças nas legislaçőes e outras } \\
\text { atividades influenciadas por terceiros }\end{array}$ & Não & \multicolumn{2}{|c|}{ Contratante retêm o risco } \\
\hline $\begin{array}{l}\text { Perigos financeiros tais como aumentos de } \\
\text { salários devido inferências estatutárias e altas de } \\
\text { inflaçôes governamentais }\end{array}$ & Nẵo & \multicolumn{2}{|c|}{ Contratante retêm o risco } \\
\hline $\begin{array}{l}\text { Perigos de morte ou ferimentos de empregados, } \\
\text { terceiros e partes públicas em geral }\end{array}$ & Sim & $\begin{array}{c}\text { Contratante retêm o risco e faz } 0 \\
\text { seguro }\end{array}$ & $\begin{array}{l}\text { Contratante transfere os riscos para } 0 \\
\text { contratado e requer que ele faça o seguro }\end{array}$ \\
\hline $\begin{array}{l}\text { Perdas de propriedade e danos nos trabalhos } \\
\text { causados por roubos, fogo, explosẫo e outras } \\
\text { causas nẫo naturais }\end{array}$ & Sim & Contratante retêm o risco e faz o seguro & $\begin{array}{l}\text { Contratante transfere os riscos para } 0 \\
\text { contratado e requer que ele faça o seguro }\end{array}$ \\
\hline $\begin{array}{l}\text { Riscos de efeitos adversos ou danos em } \\
\text { propriedades e prédios de terceiros resultantes } \\
\text { das atividades de construçấo }\end{array}$ & Sim & Contratante retêm o risco e faz o seguro & $\begin{array}{l}\text { Contratante transfere os riscos para } \\
\text { contratado e requer que ele faça o seguro }\end{array}$ \\
\hline $\begin{array}{l}\text { Danos e atrasos nos trabalhos causados por } \\
\text { condiçốes climáticas e incidentes }\end{array}$ & Parcial & $\begin{array}{l}\text { Contratante retêm o risco e } \\
\text { possivelmente pode fazer o seguro }\end{array}$ & $\begin{array}{l}\text { Contratante transfere os riscos para } 0 \\
\text { contratado }\end{array}$ \\
\hline $\begin{array}{c}\text { Riscos associados com condiçôes do solo, } \\
\text { incluindo variaçổes, dificuldades nẫo previstas e } \\
\text { movimentos de terra }\end{array}$ & Nẵo & Contratante retêm o risco & $\begin{array}{l}\text { Contratante retêm alguns riscos e transfere } \\
\text { alguns riscos para o contratado }\end{array}$ \\
\hline $\begin{array}{l}\text { Perigos que podem causar danos em veículos e } \\
\text { plantas industriais causando mortes, ferimentos } \\
\text { ou danos para terceiros e propriedades }\end{array}$ & Sim & Contratante retêm o risco e faz o seguro & $\begin{array}{l}\text { Contratante transfere os riscos para } 0 \\
\text { contratado e requer que ele faça o seguro }\end{array}$ \\
\hline $\begin{array}{l}\text { Năo cumprimento de obrigaçốes estatutórias } \\
\text { relativas aos trabalhos de construçẫo }\end{array}$ & Nẫo & \multicolumn{2}{|c|}{ Contratante retêm o risco } \\
\hline $\begin{array}{l}\text { Falhas do contratado para aderir ao programa de } \\
\text { construçẫo e ou atrasos na conclusâo do contrato }\end{array}$ & Năo & $\begin{array}{l}\text { Contratante retêm os riscos mas pode } \\
\text { requerer alguma penalidade do } \\
\text { contratado }\end{array}$ & $\begin{array}{l}\text { Contratante retêm os riscos mas requer } \\
\text { penalidades realísticas do contratado }\end{array}$ \\
\hline $\begin{array}{l}\text { Abandono do contrato pelo contratado ou } \\
\text { insolvência do contratado }\end{array}$ & Nẫo & Contratante retêm o risco & $\begin{array}{l}\text { Contratante retêm os riscos mas requer do } \\
\text { contratado parte do valor do contrato, conforme } \\
\text { claúsulas contratuais }\end{array}$ \\
\hline $\begin{array}{l}\text { Trabalho de baixa qualidade pelo contratado } \\
\text { resultando na necessidade de reparos, muita } \\
\text { manutenção ou a presença de defeitos latentes }\end{array}$ & Não & $\begin{array}{c}\text { Contratante retêm os riscos mas } \\
\text { normalmente utiliza a retençẫo de parte } \\
\text { do valor do contrato como garantia por } \\
\text { período limitado. }\end{array}$ & $\begin{array}{l}\text { Contratante retêm os riscos mas normalmente } \\
\text { utiliza a retençẫo de parte do valor do contrato } \\
\text { como garantia por período limitado. }\end{array}$ \\
\hline $\begin{array}{c}\text { Negligência de profissionais resultando em falhas } \\
\text { de desenhos de engenharia e documentaçăo de } \\
\text { contratos, ou supervisăo e administraçấo de } \\
\text { contratos inadequados }\end{array}$ & Sim & \multicolumn{2}{|c|}{ Contratante transfere os riscos para profissionais and requer deles a garantia } \\
\hline
\end{tabular}

Fonte: CIDB (2004)

(PSC, 2003) destaca que as organizações podem reduzir os riscos contratuais seguindo as seguintes diretrizes: 
- Expandir o processo de escopo do objeto: Acompanhamento intensivo dos compradores para garantir uma descrição precisa do escopo do objeto e consecutivamente um alinhamento das expectativas. A área de aquisições deve trabalhar em conjunto com a unidade de negócios para compreender as expectativas e desenvolver especificações que considerem todas as possíveis contingências e os seus efeitos em termos de contrato.

- Estabelecer modelos padrões: Contratos devem ser elaborados numa linguagem clara, com descrições detalhadas para evitar má interpretação. Um modelo padrão permitirá consistência e atendimento de todos os requisitos importantes dos termos e condições contratuais.

- Estruturar flexibilidade nos contratos: Condições e processos para término antecipado e renegociação devem ser claramente descritos nos contratos para dar aos compradores uma melhor condição de gerenciamento do contrato e estabelecer os procedimentos para minimizar problemas de relacionamento com o contratado e contratante.

A elaboração do contrato lembra (Ferrari, 2006), é a última chance de modificação de qualquer requisito antes do comprometimento final, sendo neste caso importante a elaboração do contrato pelo contratante, com termos e condições que garantam a necessidade do projeto, conforme acordado entre as partes.

\subsubsection{Administração do contrato}

O processo administração de contrato de acordo com o PMBOK (2004) garante que o desempenho do fornecedor atenda aos requisitos contratuais e que o comprador atue de acordo com os termos do contrato.

Em projetos maiores com várias aquisições de vários fornecedores, o PMBOK (2004) destaca um aspecto importante da administração de contrato que é o gerenciamento de interfaces entre os diversos fornecedores. Tais interfaces se não 
bem administradas podem gerar vários riscos para o cumprimento das condições do contrato e muitas vezes por falta do contratante.

Kerzner (2003) descreve por sua vez que a administração do contrato tem por finalidade o cumprimento das condições e termos contratuais, garantindo que o produto final do contrato seja adequado ao uso. O mesmo autor menciona as principais funções da administração do contrato, dentre elas: gerenciamento de mudanças, interpretação de especificações, aderência à qualidade, garantias, gerenciamento de subcontratados, análise de pleitos e aditivos, resolução de disputas, término do contrato, programação de pagamentos e conclusão do contrato.

O (PMBOK, 2004) destaca que a administração do contrato deve: orientar e gerenciar a execução do projeto para autorizar o trabalho da contratada no tempo adequado, gerar relatórios de desempenho, realizar o controle da qualidade para inspecionar e verificar a adequação do produto da contratada, realizar o controle integrado de mudanças para garantir que as mudanças sejam aprovadas corretamente, fazer o monitoramento e controle de riscos para garantir que os riscos sejam mitigados e fazer o monitoramento de pagamentos ao fornecedor.

A gerência do contrato para Cleland; Ireland (2002) inclui:

- Supervisionar para que o trabalho seja executado sob os termos do contrato;

- Preparar e processar as mudanças que surgirem;

- Interpretar a linguagem e as formas do contrato;

- Aprovar as faturas, na medida em que se executa o trabalho

As ferramentas e técnicas sugeridas pelo PMBOK (2004) para a administração dos contratos incluem: sistema de controle de mudanças, análises de desempenho conduzidas pelo comprador, inspeções e auditorias, relatórios gerais de desempenho, sistemas de pagamentos, administração de reclamações, sistema de gerenciamento de registros e tecnologia da informação.

Ferrari apud Houston (1996) destaca que são necessários três elementos para uma administração de contrato com sucesso: 
- um contrato que defina claramente os requisitos técnicos e administrativos do fornecimento;

- um fornecedor que seja suficientemente qualificado para executar o fornecimento especificado;

- um processo efetivo de administração do contrato que garanta a execução do fornecimento de acordo com os requisitos técnicos e administrativos estabelecidos.

As análises de desempenho realizadas durante a administração dos contratos, segundo o PMBOK (2004), identificam sucessos ou falhas de desempenho, progresso em relação à declaração do trabalho do contrato e não-conformidades do contrato permitindo que o comprador quantifique a capacidade ou incapacidade demonstrada pelo fornecedor para realizar o trabalho.

As reclamações do contrato para o PMBOK (2004) devem ser documentadas, processadas, monitoradas e gerenciadas durante todo do ciclo de vida do contrato, e de acordo com os termos do contrato. Se as partes não resolverem uma reclamação por conta própria, talvez ela precise ser tratada de acordo com os procedimentos de resolução de disputas estabelecidos no contrato.

O uso das tecnologias da informação e de comunicação de acordo com o PMBOK (2004) pode aumentar a eficiência e a eficácia da administração do contrato automatizando partes do sistema de gerenciamento de registros, do sistema de pagamentos, da administração de reclamações ou do relatório de desempenho e oferecendo a troca de dados eletrônicos entre o comprador e o fornecedor.

A documentação do contrato para o PMBOK (2004) também inclui as documentações técnicas desenvolvidas pelo fornecedor e outras informações sobre o desempenho do trabalho, como entregas, relatórios de desempenho do fornecedor, garantias, documentos financeiros, inclusive notas fiscais e registros de pagamentos, e os resultados de inspeções relacionadas ao contrato. Esses documentos podem formar a base para a rescisão do contrato do fornecedor ou para a determinação de como as penalidades, remunerações ou incentivos do contrato serão administrados. 
Para Kerzner (2003) a maior parte do tempo da administração dos contratos é gasta no gerenciamento das mudanças. Tais mudanças destacam o mesmo autor, são normalmente devidas a mudanças administrativas, modificações contratuais, acordos suplementares e mudanças construtivas.

Para as mudanças construtivas, aquelas devido à necessidade da execução do trabalho de forma diferente do especificado no contrato, (KERZNER, 2003) destaca as seguintes causas típicas:

- Erros na especificação com impossibilidade de desempenho;

- Erros de interpretação do contrato;

- Inspeção detalhada do trabalho;

- Falha em itens que requerem um conhecimento não planejado;

- Aceleração do desempenho;

- Atrasos em partes de fornecimentos do contratado ou contratante;

- Falha na cooperação;

- Mal uso de dados proprietários.

Ferrari (2006) destaca que a grande maioria dos problemas ocorridos durante a fase de gerenciamento dos contratos é devida a falta de atenção na declaração do escopo do trabalho.

Baseados nos termos e condições contratuais, (KERZNER, 2003) destaca que o cliente tem o direito de encerrar o contrato por sua conveniência a qualquer momento. Entretanto para isto, o cliente precisa compensar o contratado por suas atividades de preparação e por qualquer trabalho já encerrado e aceito pelo cliente.

Para a mitigação dos riscos contratuais, (KERZNER, 2003) recomenda incluir nas propostas e contratos os seguintes itens: escopo dos serviços e descrição do projeto, termos de administração do contrato, termos de pagamento, obrigações do cliente e itens fornecidos, garantias, limitações de responsabilidades e danos consequênciais, indenizações, taxas, indenizações por patentes, informações 
confidenciais, provisão de encerramento, mudanças e extras, designações, atrasos (incluindo força maior).

Em algumas organizações segundo Kerzner (2003) utiliza-se de listas de verificação para a elaboração de propostas e contratos de forma a garantir a incorporação de itens relevantes nos documentos. A tabela 11 ilustra uma lista de verificação típica dos principais itens a serem considerados.

Tabela 11 - Lista de verificação de contratos

\begin{tabular}{|c|c|}
\hline Item & Descrição \\
\hline & \\
\hline I & Definiçẫo dos termos contratuais \\
\hline II & Definiçẫo do escopo do projeto \\
\hline III & Escopo dos serviços e trabalho a ser realizado \\
\hline IV & Lista dos itens a serem fornecidos pelo cliente \\
\hline V & Gerenciamento de mudanças e extras \\
\hline VI & Garantias \\
\hline VII & Termos de pagamento \\
\hline VIII & Definiçẫo do custo de base (custo do contrato) \\
\hline IX & Impostos \\
\hline X & Cutras provisốes contratuais \\
\hline XI & Provisốes gerais \\
\hline XII & XIII \\
\hline
\end{tabular}

Fonte: Adaptado (Kerzner, 2003)

As diversas atividades envolvidas nos processos de gerenciamento de aquisições do projeto compõem o ciclo de vida de um contrato. Um projeto complexo de acordo com o PMBOK (2004) pode envolver o gerenciamento de vários contratos ou subcontratos simultaneamente ou em seqüência.

Segundo Kerzner (2004) à medida que os projetos começam a crescer em tamanho e complexidade, passa a ser requerido um esforço de gerenciamento de riscos também entre contratados e subcontratados.

O CIDB (2004) lembra que muitas condições não previstas, ou eventos inesperados, podem também gerar aumento de custos, além da definição por conta do contratante de expectativas de prazos e custos de construção não realísticos, 
forçando os contratados a situações difíceis ou compromissos os quais podem ser não realísticos.

Especificamente a indústria da construção de acordo com o CIDB (2004) é muito competitiva por natureza e frequentemente, disputas acontecem sobre os direitos e obrigações das partes, particularmente onde riscos não esperados resultaram em perdas financeiras. Em tais situações, o relacionamento entre as partes fica abalado e frequentemente os esforços são concentrados para outros objetivos diferentes daqueles estabelecidos de concluir o projeto com qualidade, no prazo e dentro do orçamento.

Esta má alocação e percepção dos riscos envolvidos segundo Kerzner (2004) podem resultar em pagamentos superiores para o contratante além de atrasos para utilização das instalações. Desta forma, uma atenção especial necessita ser tomada quando do desenvolvimento dos documentos de contrato dos projetos para garantir que os riscos foram cuidadosamente alocados e entendidos de forma apropriada para a mais adequada parte.

\subsubsection{Encerramento do contrato}

O PMBOK (2004) descreve o processo de encerramento do contrato como suporte ao processo de encerrar o projeto, pois ele envolve a confirmação de que todo o trabalho e as entregas foram aceitáveis. Estas entregas e os critérios de aceitação para o encerramento formal do contrato geralmente são definidos nos termos do contrato e são incluídos no plano de gerenciamento de contratos.

Segundo Ferrari (2006) o principal resultado do encerramento do contrato é a de possibilitar o término do relacionamento contratual com o fornecedor.

O processo de encerramento de contrato é realizado no ciclo de vida dos projetos à medida que os contratos de um projeto vão sendo concluídos. Ele envolve atividades administrativas, como a atualização de registros para refletir resultados finais e o arquivamento dessas informações para uso futuro. 
A rescisão de um contrato de acordo com o PMBOK (2004) é um caso especial de encerramento do contrato e pode resultar de um acordo mútuo entre as partes ou de descumprimento das obrigações de uma das partes.

(FERRARI, 2006) menciona que o encerramento do contrato envolve também o acerto de todas as pendências que ocorreram durante o fornecimento, como complementações, justificativas, reparos, retrabalhos e condicionantes para a aceitação final.

Uma atividade normalmente aplicável aos processos de aquisição destaca o PMBOK (2004) é a auditoria de aquisição, cujo objetivo é identificar sucessos e falhas que forneçam um embasamento para o reconhecimento na preparação ou na administração de outros contratos de aquisição no projeto ou em outros projetos dentro da organização executora.

Importante ressaltar da importância da documentação das lições aprendidas no encerramento dos contratos, com o objetivo de capturar aprendizado e melhorias para o planejamento e a execução de compras e aquisições futuras. 


\section{METODOLOGIA DA PESQUISA}

Este capítulo apresenta a metodologia adotada para este projeto de pesquisa e está dividido da seguinte forma. O item 3.1 contextualiza os problemas explorados na pesquisa para fundamentar a decisão da escolha da metodologia a ser utilizada. No item 3.2 é apresentada uma revisão teórica da classificação tradicional de um projeto de pesquisa e define-se a classificação utilizada. O item 3.3 fundamenta o método utilizado para o projeto de pesquisa e por fim o item 3.4 descreve as técnicas utilizadas e faz as considerações finais em que se resume a estrutura metodológica da pesquisa.

\subsection{Os Problemas Explorados na Pesquisa}

Para Gil (1999), a pesquisa tem um caráter pragmático, é um "processo formal e sistemático de desenvolvimento do método científico". O objetivo fundamental da pesquisa é descobrir respostas para problemas mediante o emprego de procedimentos científicos.

Pode-se também de acordo com Silva (2001) descrever a pesquisa como um conjunto de ações, propostas para encontrar a solução para um problema, que têm por base procedimentos racionais e sistemáticos. A pesquisa é realizada quando se tem um problema e não se tem informações para solucioná-lo.

(SILVA, 2001) destaca que uma vez que a pesquisa também é a construção de conhecimento original de acordo com certas exigências científicas é extremamente importante estruturar o planejamento da pesquisa, obedecendo-se critérios de coerência, consistência, originalidade e objetivação. Para isto é desejável que uma pesquisa científica preencha os seguintes requisitos:

a) a existência de uma pergunta que se deseja responder;

b) a elaboração de um conjunto de passos que permitam chegar à resposta;

c) "a indicação do grau de confiabilidade na resposta obtida" (SILVA apud GOLDEMBERG, 1999). 
Segundo Silva (2001) o planejamento de uma pesquisa dependerá basicamente de três fases; decisória, construtiva e redacional. Na fase decisória o tema é escolhido e é feita a definição e delimitação do problema de pesquisa. Na fase construtiva é desenvolvido o plano de pesquisa e finalmente na fase redacional são analisados os dados e informações obtidas na fase construtiva, visando à organização e sistematização das idéias e a elaboração do relatório final.

(CERVO; BERVIAN, 1983) descreve de forma gráfica na figura 18 o planejamento de um projeto de pesquisa, dividindo-a numa parte investigativa e numa segunda de comunicação da pesquisa.

Figura 18 - Planejamento da pesquisa

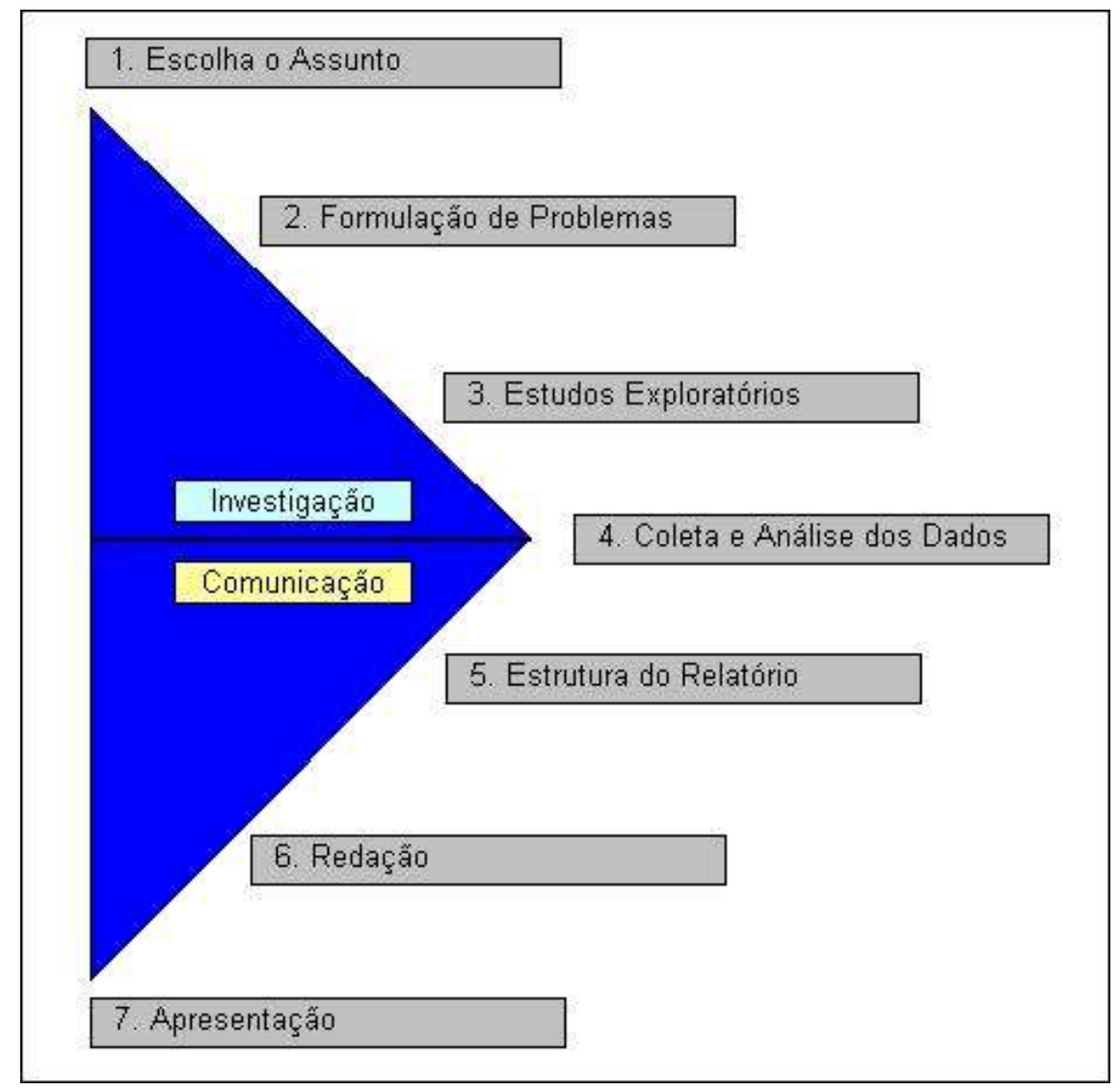

Fonte: Adaptado de (Cervo \& Bervian, 1983)

Este projeto de pesquisa faz a análise da gestão de riscos aplicada nas aquisições de bens e serviços para os projetos de bens de capital, buscando identificar o conhecimento teórico sobre este tema e capturar a atual prática das empresas de 
maneira a apresentar uma recomendação para a gestão de riscos dos projetos de bens de capital com foco nas aquisições.

Para alcançar os objetivos do projeto de pesquisa foram definidas as seguintes perguntas para o problema:

Tabela 12 - Problemas explorados na pesquisa

\begin{tabular}{|c|l|}
\hline Pergunta & \multicolumn{1}{c|}{ Descriçäo } \\
\hline P1: & $\begin{array}{l}\text { As empresas de relevante atuação no contexto de projetos de bens de capital reconhecem o valor do gerenciamento de } \\
\text { riscos aplicado na aquisiçẫo de bens e serviços para o sucesso dos projetos de bens de capital? }\end{array}$ \\
\hline P2: & $\begin{array}{l}\text { Como está estruturado o gerenciamento de riscos das aquisiçỗes nas empresas de relevante atuaçẫo no contexto de } \\
\text { projetos de bens de capital do mercado brasileiro e internacional? }\end{array}$ \\
\hline P3: & $\begin{array}{l}\text { Quais sẫo as categorias de riscos no processo de aquisiçẫo mais relevantes do ponto de vista das empresas para o } \\
\text { sucesso da implantaçẫo dos projetos de bens de capital? }\end{array}$ \\
\hline P4: & $\begin{array}{l}\text { Qual a aderência entre as práticas aplicadas nas empresas e aquelas definidas na teoria do gerenciamento de riscos } \\
\text { aplicada nas aquisiçôes de bens e serviços para os projetos de bens de capital? }\end{array}$ \\
\hline P5: & $\begin{array}{l}\text { Quais sẫo as práticas relacionadas ao gerenciamento de riscos das aquisiçốes de bens e serviços que já estẫo } \\
\text { consolidadas e aquelas que ainda nẫo encontram práticas comuns identificadas? }\end{array}$ \\
\hline
\end{tabular}

Fonte: Elaborada pelo autor

\subsection{Classificação da Pesquisa}

Existe de acordo com Silva (2006) várias formas de classificar as pesquisas. As formas mais tradicionais classificam as pesquisas quanto a sua natureza, a sua forma de abordagem e quanto aos seus objetivos.

Do ponto de vista da sua natureza (SILVA, 2006) menciona que a pesquisa pode ser classificada em básica e aplicada. A pesquisa básica objetiva gerar conhecimentos novos úteis para o avanço da ciência sem aplicação prática prevista. Ela envolve verdades e interesses universais. Já a pesquisa aplicada objetiva gerar conhecimentos para aplicação prática dirigidos à solução de problemas específicos. Ela envolve verdades e interesses locais.

No caso desta pesquisa, a idéia é a de gerar conhecimentos práticos para o problema específico dos riscos envolvidos na aquisição de bens e serviços e os quais poderiam ser utilizados pela empresas que fazem o gerenciamento de projetos de bens de capital, bem como por instituições de ensino. 
Do ponto de vista da forma de abordagem do problema (SILVA, 2006) destaca que as pesquisas podem ser classificadas como quantitativa e qualitativa. A pesquisa quantitativa considera que tudo pode ser quantificável, o que significa traduzir em números opiniões e informações para classificá-las e analisá-las. Requer o uso de recursos e de técnicas estatísticas (percentagem, média, moda, mediana, desviopadrão, coeficiente de correlação, análise de regressão, etc.). Já a pesquisa qualitativa considera que há uma relação dinâmica entre o mundo real e o sujeito, isto é, um vínculo indissociável entre o mundo objetivo e a subjetividade do sujeito que não pode ser traduzido em números. A interpretação dos fenômenos e a atribuição de significados são básicas no processo de pesquisa qualitativa. Não requer o uso de métodos e técnicas estatísticas. O ambiente natural é a fonte direta para coleta de dados e o pesquisador é o instrumento-chave. É descritiva e os pesquisadores tendem a analisar seus dados indutivamente. O processo e seu significado são os focos principais de abordagem.

Este projeto de pesquisa é qualitativo, pois buscará através da observação de procedimentos e aplicações de gestão de riscos nas empresas, bem como através dos conhecimentos identificados na teoria, fazer uma interpretação destes fenômenos e atribuir significados de forma indutiva.

Do ponto de vista de seus objetivos (Gil, 1991) menciona que as pesquisas podem ser classificadas como: exploratória, descritiva e explicativa. A pesquisa exploratória visa proporcionar maior familiaridade com o problema com vistas a torná-lo explícito ou a construir hipóteses. Envolve levantamento bibliográfico; entrevistas com pessoas que tiveram experiências práticas com o problema pesquisado; análise de exemplos que estimulem a compreensão. Assume, em geral, as formas de pesquisas bibliográficas e estudos de caso. A pesquisa descritiva visa descrever as características de determinada população ou fenômeno ou o estabelecimento de relações entre variáveis. Envolve o uso de técnicas padronizadas de coleta de dados: questionário e observação sistemática. Assume, em geral, a forma de levantamento. Já a pesquisa explicativa visa identificar os fatores que determinam ou contribuem para a ocorrência dos fenômenos. aprofunda o conhecimento da realidade porque explica a razão, o "por que" das coisas. Quando realizada nas ciências naturais, requer o uso do método experimental, e nas ciências sociais 
requer o uso do método observacional. Assume, em geral, a formas de pesquisa experimental e pesquisa expost-facto.

Esta pesquisa busca a familiaridade com a bibliografia e os fatos relevantes do tema através do contato com as empresas, de forma que podemos classificá-la como exploratória.

Desta forma resumindo podemos dizer que este projeto de pesquisa é aplicado, qualitativo e exploratório.

\subsection{Métodos Utilizados na Pesquisa}

Método científico é o conjunto de processos ou operações mentais que se devem empregar na investigação. É a linha de raciocínio adotada no processo de pesquisa. Os métodos que fornecem as bases lógicas à investigação são: dedutivo, indutivo, hipotético-dedutivo, dialético e fenomenológico (GIL, 1999; LAKATOS; MARCONI, 1993).

A linha deste projeto de pesquisa será indutiva, pois buscará através da revisão dos conhecimentos de instituições e associações representativas da área de gerenciamento de projetos, bem como de livros e artigos reconhecidos na comunidade acadêmica e da observação de um universo pequeno, porém relevante de empresas que gerenciam projetos de bens de capital no Brasil e no exterior, extrair generalizações para o problema da pesquisa.

Os procedimentos técnicos para os projetos de pesquisa citados tradicionalmente e mencionados por (Gil, 1991), são a pesquisa bibliográfica, a pesquisa documental, a pesquisa experimental, o levantamento, o estudo de caso, pesquisa expost-facto, pesquisa-ação e a pesquisa participante.

A pesquisa bibliográfica é o procedimento elaborado a partir de material já publicado, constituído principalmente de livros, artigos de periódicos e atualmente com material disponibilizado na Internet. 
A pesquisa documental é o procedimento elaborado a partir de materiais que não receberam tratamento analítico.

A pesquisa experimental é o procedimento que determina um objeto de estudo, selecionam-se as variáveis que seriam capazes de influenciá-lo, definem-se as formas de controle e de observação dos efeitos que a variável produz no objeto.

O levantamento é o procedimento que envolve a interrogação direta das pessoas cujo comportamento se deseja conhecerem.

estudo de caso, por sua vez envolve o estudo profundo e exaustivo de um ou poucos objetos de maneira que se permita o seu amplo e detalhado conhecimento.

A pesquisa expost-facto é quando o "experimento" se realiza depois dos fatos.

Já a pesquisa-ação é o procedimento que é concebido e realizado em estreita associação com uma ação ou com a resolução de um problema coletivo. Os pesquisadores e participantes representativos da situação ou do problema estão envolvidos de modo cooperativo ou participativo.

E por fim a pesquisa participante é quando se desenvolve a partir da interação entre pesquisadores e membros das situações investigadas.

Para solucionar o problema proposto por este projeto de pesquisa, faz-se necessário o conhecimento num nível profundo e exaustivo da gestão de riscos aplicada as aquisições de bens e serviços para os projetos de bens de capital, de maneira que o procedimento mais adequado e adotado foi o estudo de caso.

(SILVA, 2001) lembra que os tipos de pesquisa apresentados nas diversas classificações não são estanques. Uma mesma pesquisa pode estar ao mesmo tempo, enquadrada em várias classificações, desde que obedeça aos requisitos inerentes a cada tipo. 


\subsection{Técnicas Aplicadas na Pesquisa}

A definição das técnicas que foram utilizadas para a pesquisa, partiu do questionamento de onde e como seria realizada a pesquisa, da definição do tipo de pesquisa, a população (universo da pesquisa), a amostragem, os instrumentos de coleta de dados e da forma como se pretendia tabular e analisar seus dados.

Para esta definição foi importante o entendimento dos conceitos de população e amostra. População (ou universo da pesquisa) é a totalidade de indivíduos que possuem as mesmas características definidas para um determinado estudo. Já a amostra é parte da população ou do universo, selecionada de acordo com uma regra ou plano. A amostra pode ser probabilística e não-probabilística.

Segundo Silva (2001) estas amostras não-probabilísticas podem ser: acidentais, por quotas ou intencionais. As amostras acidentais são compostas por acaso, com pessoas que vão aparecendo; as amostras por quotas derivam de diversos elementos constantes da população/universo, na mesma proporção e a amostra intencional é aquela onde são escolhidos casos para a amostra que representem o "bom julgamento" da população/ universo.

Para definição das amostras recomenda-se a aplicação de técnicas estatísticas. Barbetta apud Silva (2001) fornece uma abordagem muito didática referente à delimitação de amostras e ao emprego da estatística em pesquisas.

No caso desta pesquisa por utilizar o método indutivo e o estudo de caso, definiu-se pelo uso da amostra não-probabilística e intencional. Sendo que as empresas selecionadas foram escolhidas intencionalmente por representarem muito bem a população/universo para a pesquisa.

A definição do instrumento de coleta de dados de acordo com (SILVA, 2001) dependerá dos objetivos que se pretende alcançar com a pesquisa e do universo a ser investigado. Os instrumentos de coleta de dados tradicionais são as observações, as entrevistas, os questionários e os formulários. 
Sendo o procedimento escolhido para a pesquisa o estudo de caso, se optou pela utilização das entrevistas e questionários para a coleta de dados, utilizando-os da forma mais adequada, no intuito de obter os melhores resultados possível para o atendimento dos objetivos da pesquisa.

Segundo Silva (2001) a entrevista é a obtenção de informações de um entrevistado, sobre determinado assunto ou problema. A entrevista pode ser:

- padronizada ou estruturada: roteiro previamente estabelecido;

- não padronizada ou não-estruturada: não existe rigidez de roteiro. Podemse explorar mais amplamente algumas questões.

(SILVA, 2001) lembra que o questionário é uma série ordenada de perguntas que devem ser respondidas por escrito pelo informante, sendo importante que o questionário seja objetivo, limitado em extensão e estar acompanhado de instruções As instruções devem esclarecer o propósito de sua aplicação, ressaltar a importância da colaboração do informante e facilitar o preenchimento.

Young e Lundberg (apud Pessoa, 1998) fizeram uma série de recomendações úteis à construção de um questionário.

Entre elas destacam-se:

- O questionário deverá ser construído em blocos temáticos obedecendo a uma ordem lógica na elaboração das perguntas;

- A redação das perguntas deverá ser feita em linguagem compreensível ao informante. A linguagem deverá ser acessível ao entendimento da média da população estudada. A formulação das perguntas deverá evitar a possibilidade de interpretação dúbia, sugerir ou induzir a resposta;

- Cada pergunta deverá focar apenas uma questão para ser analisada pelo informante;

- O questionário deverá conter apenas as perguntas relacionadas aos objetivos da pesquisa. Devem ser evitadas perguntas que, de antemão, já se sabe que não serão respondidas com honestidade. 
Para aproveitar ao máximo o potencial dos casos a serem estudados optou-se por utilizar as entrevistas nas formas padronizadas e não padronizada, dando liberdade ao entrevistado para dar informações complementares de forma que se pudessem capturar itens não identificados contribuindo para a conclusão dos estudos.

Para o questionário se optou pela utilização de questões de múltiplas escolhas e também por questões abertas dirigidas para identificação de práticas complementares do objeto de estudo.

Para a coleta de dados procurou-se organizar os instrumentos de pesquisa de maneira a proporcionar uma interação efetiva entre o pesquisador, o informante e a pesquisa que está sendo realizada, codificando as questões e respostas mantendose sempre o relacionamento da coleta de dados com o problema a ser resolvido.

\subsection{Procedimentos Considerados na Pesquisa}

A tabela 13 abaixo resume os procedimentos considerados na pesquisa:

Tabela 13 - Resumo dos procedimentos da pesquisa

\begin{tabular}{|c|c|c|}
\hline Categorização da Pesquisa & Definiçäo & Comentários \\
\hline Natureza & Aplicada & $\begin{array}{l}\text { Gera conhecimentos para aplicaçẫo prática dirigida à soluçẫo } \\
\text { de problemas específicos }\end{array}$ \\
\hline Abordagem & Qualitativa & Interpreta fenômenos e atribui significados de forma indutiva \\
\hline Objetivos & Exploratória & $\begin{array}{l}\text { Busca familiaridade com a bibliografia e fatos relevantes do } \\
\text { tema nas empresas }\end{array}$ \\
\hline Método utilizado & Indutivo & Universo pequeno porém relevante de empresas \\
\hline Procedimentos técnicos & Estudo de Caso & Estudo profundo e exaustivo de um ou poucos objetos \\
\hline Técnicas aplicadas & Amostra não probabilística e intencional & Empresas do estudo de caso escolhidas de forma intencional \\
\hline Instrumento de coleta de dados & Entrevistas e questionários & Capacidade de coleta ampla de dados \\
\hline Tipo das entrevistas & Forma padronizada e não padronizada & $\begin{array}{l}\text { Máximo potencial dos casos, dando liberdade ao entrevistado } \\
\text { para dar inclusive informaçốes complementares }\end{array}$ \\
\hline Tipo de questionário & $\begin{array}{l}\text { Questốes de múltipla escolha e } \\
\text { questôes abertas }\end{array}$ & Possibilidade de identificaçẫo de práticas complementares \\
\hline
\end{tabular}




\section{INSTRUMENTO DE PESQUISA}

Para a obtenção das informações necessárias para esta pesquisa, foi elaborado um questionário com base nos fundamentos teóricos do gerenciamento de riscos e com foco nas aquisições de bens e serviços para os projetos de bens de capital (PMBOK,2004; KERZNER,2003).

O questionário foi estruturado de forma a contribuir nas respostas para as questões chave a serem respondidas na pesquisa, descritas abaixo:

P1: As empresas de relevante atuação no contexto de projetos de bens de capital reconhecem o valor do gerenciamento de riscos aplicado na aquisição de bens e serviços para o sucesso dos projetos de bens de capital?

P2: Como está estruturado o gerenciamento de riscos das aquisições nas empresas de relevante atuação no contexto de projetos de bens de capital do mercado brasileiro e internacional?

P3: Quais são as categorias de riscos no processo de aquisição mais relevantes do ponto de vista das empresas para o sucesso da implantação dos projetos de bens de capital?

P4: Qual a aderência entre as práticas aplicadas nas empresas e aquelas definidas na teoria do gerenciamento de riscos aplicada nas aquisições de bens e serviços para os projetos de bens de capital?

P5: Quais são as práticas relacionadas ao gerenciamento de riscos das aquisições de bens e serviços que já estão consolidadas e aquelas que ainda não encontram práticas comuns identificadas?

O questionário foi dividido em 5 partes, sendo as 2 primeiras introdutórias com a caracterização da empresa e dados do perfil do entrevistado e as 3 últimas propriamente ditas com informações de dados essenciais para responder as perguntas chave da pesquisa. A figura 19 mostra a estruturação das categorias das questões essenciais do questionário de pesquisa. 
Figura 19 - Estrutura do questionário de pesquisa

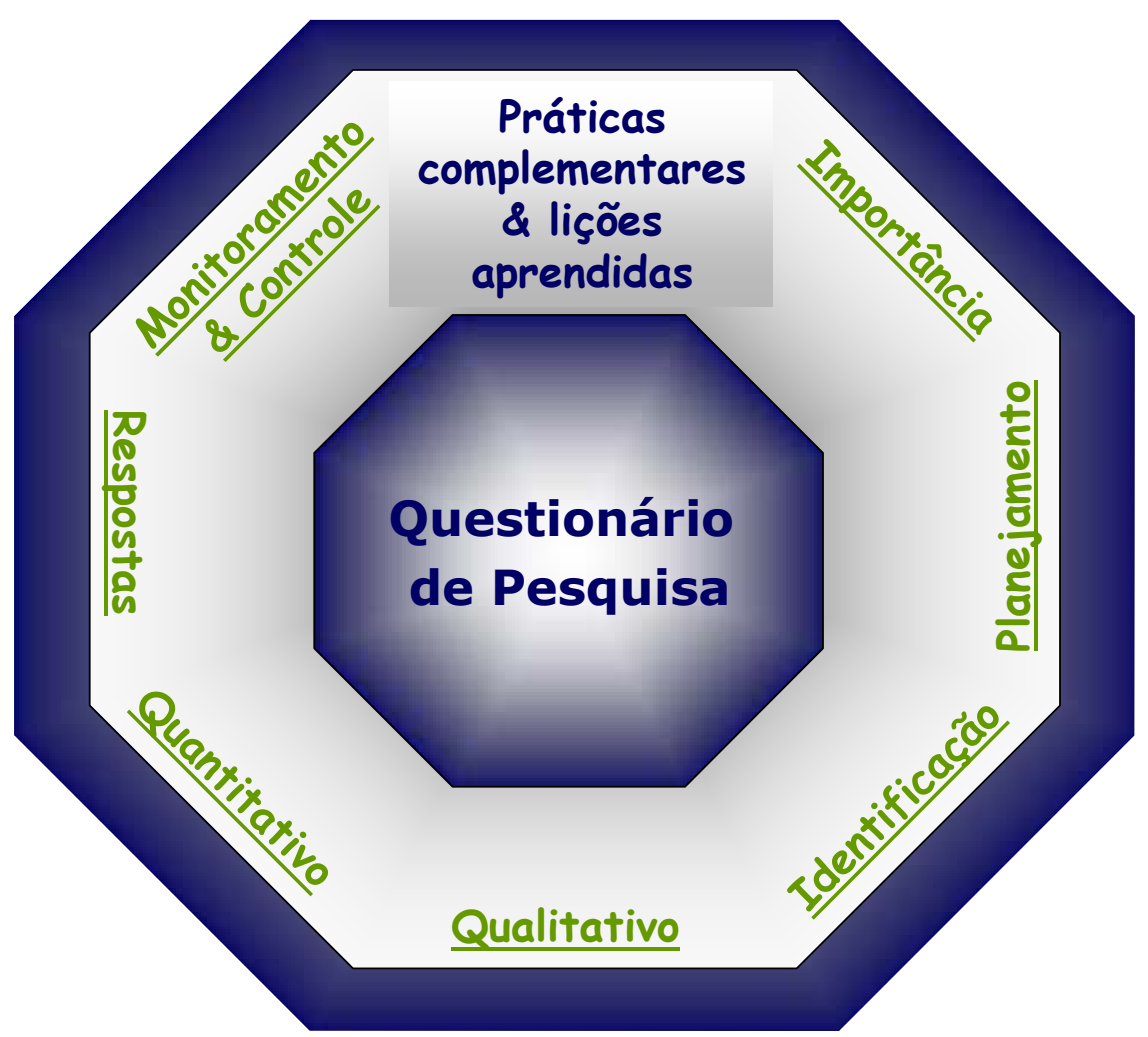

Fonte: Elaborada pelo autor

O questionário mistura questões de múltipla escolha com a utilização da escala Likert (1961) e questões abertas, sendo respondido em entrevistas presenciais com os entrevistados no intuito de capturar outras informações não identificados no questionário. O capítulo 9 deste trabalho no seu anexo $A$, traz o questionário utilizado na íntegra.

A questão $1(\mathrm{P} 1)$ é respondida com base no item 3 do questionário - referenciada como a categoria "IMPORTÂNCIA" da figura 19. Neste item se utilizou sete perguntas chave indiretas relativas a riscos, aquisições, escritório de projetos e estratégias de aquisições, para capturar o valor dado pela empresa para o gerenciamento de projetos e em especial o gerenciamento de riscos das aquisições.

A questão 2 (P2) é respondida com base nos dados obtidos das outras categorias do processo da gestão de riscos, planejamento, identificação, análise qualitativa, 
análise quantitativa, plano de respostas e monitoramento e controle, os quais incluem também no item de planejamento uma questão aberta sobre a estrutura organizacional da empresa para o gerenciamento de riscos das aquisições.

Para a classificação dos processos de gerenciamento de riscos da empresa com base nos resultados das entrevistas, se caracterizou cada processo de risco em 3 condições; ponto forte, em desenvolvimento e não desenvolvido. Respostas na escala Likert de 5 foi considerado como ponto forte, respostas 3 e 4 como em desenvolvimento e 1 e 2 como não desenvolvido. Aqui vale lembrar que o autor considerou também informações obtidas durante as entrevistas, para consolidar as condições do processo de riscos.

A questão 3 (P3) é respondida com base nos dados obtidos da categoria de processo "IDENTIFICAÇÃO". Nesta parte do questionário existem 2 questões abertas, uma relativa à estrutura analítica de riscos típica da empresa e outra para identificação das categorias de riscos mais relevantes do ponto de vista da empresa para o sucesso dos projetos.

As questões 4 e 5 (P4 e P5) são respondidas através da análise dos dados teóricos obtidos durante os estudos e com as evidências práticas capturadas nas entrevistas obtidas nos estudos de casos envolvendo basicamente todas as categorias do questionário e em especial as práticas complementares das empresas e as lições aprendidas.

Os resultados das entrevistas estão descritos nos estudos de casos. 


\section{ESTUDOS DE CASOS}

\subsection{Seleção das Empresas}

Para a seleção das empresas a serem estudas nesta pesquisa, buscou-se aquelas com uma carteira de projetos de bens de capital relevante, cujos valores e complexidades dos seus empreendimentos, bem como o momento atual dos seus respectivos segmentos de negócio fossem significativos para o desenvolvimento de uma cultura de gerenciamento de projetos, de modo a capturar experiências de empresas com procedimentos corporativos de gerenciamento de projetos e especificamente gerenciamento de riscos bem estruturados.

Outra estratégia na escolha das empresas foi a de misturar empresas com área de aquisições e riscos corporativa centralizada e empresas com estas mesmas áreas descentralizadas dedicadas a um projeto específico e relevante de bens de capital, desta forma buscando capturar diferentes experiências destes dois tipos de organizações.

E finalmente, outro critério de seleção das empresas foi a de mesclar empresas nacionais e internacionais e com escolas típicas de referência de gerenciamento de projetos diferentes, com o intuito de aprender com a experiência internacional e com tipos de escolas diferentes.

\subsection{Perfil dos Entrevistados}

Dentre as empresas selecionadas, buscou-se inicialmente um contato por telefone através de contatos do próprio pesquisador com o objetivo de validar os critérios de seleção das empresas e identificar os profissionais adequados dentro das empresas pesquisadas para organização e programação das entrevistas.

De cada empresa foi selecionado 2 profissionais, sendo um de nível executivo e outro de nível técnico, com grande experiência em gerenciamento de projetos e com forte atuação nas áreas de aquisição e riscos para projetos de bens de capital. Anteriormente as entrevistas foi explicado para cada profissional das empresas os objetivos da pesquisa, a dinâmica do processo e o grau de sigilo, mencionando que a pesquisa tinha objetivo acadêmico, preservando-se o nome dos entrevistados, 
bem como das empresas e desta forma deixando-os mais tranqüilos para discutir e responder ao questionário.

Ficou acordado com os entrevistados que eles poderiam estar recebendo os resultados da pesquisa, de forma que pudessem estar aferindo as suas práticas com as recomendações teóricas e de outras empresas.

Todas as entrevistas foram realizadas nos escritórios das próprias empresas, onde foram respondidos os questionários e discutidos os itens das práticas e experiências adicionais das empresas de forma bastante enriquecedora para a pesquisa.

\subsection{Caso A}

A empresa estudada é uma empresa internacional do segmento de mineração, sediada no Canadá com mais de 100 anos de existência, contando atualmente com cerca de 15000 colaboradores e com escritórios e fábricas em várias partes do mundo. O faturamento mundial em 2006 alcançou cerca de US\$ 8 bilhões. A empresa A possui um escritório de gerenciamento de projetos que define e mantêm as melhores práticas para os projetos nas Américas e faz auditorias nos projetos da empresa em outras regiões. A carteira de projetos da empresa atual é da ordem de US\$10 bilhões, sendo o valor médio dos projetos estratégicos da ordem de US\$400 milhões e a duração típica dos projetos de 4 a 6 anos.

\subsubsection{Objeto}

Para o estudo de caso foi analisado um projeto específico de grande porte da empresa A com valor de US\$ 3 Bilhões em implantação na Oceania e gerenciado na Austrália.

Embora a empresa A possua um escritório de projetos corporativos no Canadá, devido à complexidade e localização do projeto objeto deste estudo, a organização de aquisições e riscos definida para o projeto pela empresa A é descentralizada com todas as aquisições e atividades de gerenciamento de riscos sendo realizadas através do escritório de gerenciamento de projetos na Austrália.

Um dos grandes desafios do projeto objeto deste estudo são as questões logísticas, suprimentos, diferenças culturais e restrições de implantação devido à localização da obra. O projeto utiliza-se da modalidade de implantação EPCM, através de um 
consórcio de 2 empresas de engenharia reconhecidas internacionalmente e administradas por um grupo de gestores da própria empresa A. Por definição da empresa $A$, optou-se especificamente para este projeto, devido às suas condições técnicas e complexidade, do desenvolvimento de procedimentos e sistemas de gerenciamento de projetos específicos, utilizando-se das experiências anteriores das empresas internacionais consorciadas.

O projeto no momento da pesquisa encontrava-se na sua fase final de implantação, já com resultados práticos das práticas analisadas.

\subsubsection{Metodologia}

Para este caso específico o pesquisador teve também a oportunidade de visitar o local das obras além dos escritórios da empresa A na Austrália. Isto contribuiu para uma maior compreensão da complexidade do objeto de estudo e para uma verificação com o pessoal de construção e logística da aplicabilidade do processo de riscos e das lições aprendidas. As entrevistas no escritório de gerenciamento do projeto ocorreram nos dias 20 e 21 de Fevereiro de 2007. Sendo no dia 20 de fevereiro uma entrevista e discussão do questionário com o gerente de suprimentos e contratos do projeto, com duração aproximada de 2 horas e no dia 21 de fevereiro com um analista sênior de compras com duração aproximada de 1 hora. Na primeira fase das entrevistas foi feita uma introdução com os objetivos da pesquisa e procurou-se deixar os entrevistados inicialmente livres para expor sobre o processo de gestão de riscos nas aquisições de bens e serviços e numa segunda fase foi utilizado o questionário para completar os itens ainda não respondidos. Na fase final houve um tempo para discussão das lições aprendidas e recomendações para outros projetos.

A visita ao local da obra ocorreu no dia 02 de março de 2007, e teve a duração de 6 horas. Neste período foi realizada uma visita as instalações e obras do projeto, acompanhados pelo coordenador de construção e coordenador de logística da operação sendo utilizada parte deste período da visita para discussão sobre os aspectos de riscos do projeto e em especial as lições aprendidas do processo de gestão de riscos das aquisições. 


\subsubsection{Gerenciamento de riscos das aquisições na empresa A}

\subsubsection{Reconhecimento da importância}

Para aferirmos a importância e consideração que a empresa A dá ao processo de gerenciamento de riscos das aquisições de bens e serviços, utilizou sete perguntas chave indiretas relativas a riscos, aquisições, escritório de projetos e estratégias de aquisições.

A figura 20 abaixo mostra que o objeto de estudo do caso $A$, possui uma alta aderência aos níveis mínimos de processos requeridos para a utilização e aplicação do gerenciamento de riscos aplicados nas aquisições de bens e serviços. A empresa A possui um procedimento corporativo de gerenciamento de riscos de projetos, incluindo também procedimento específico para os riscos envolvidos nas aquisições, capacita os envolvidos no processo de riscos, possui procedimentos corporativo para as aquisições utilizando-se de métricas para medir o desempenho das aquisições, centraliza as melhores práticas de gerenciamento de projetos em um escritório de projetos e utiliza parte dos resultados de riscos para revisão das estratégias das aquisições. Adiante se descreve em mais detalhes a estruturação do processo comprovando a importância dada pela empresa $\mathrm{A}$ ao gerenciamento de riscos das aquisições.

Figura 20 - Importância do gerenciamento de riscos das aquisições - caso A

\section{IMPORTÂNCIA DO GERENCIAMENTO DE RISCOS DAS AQUISIÇÕES}

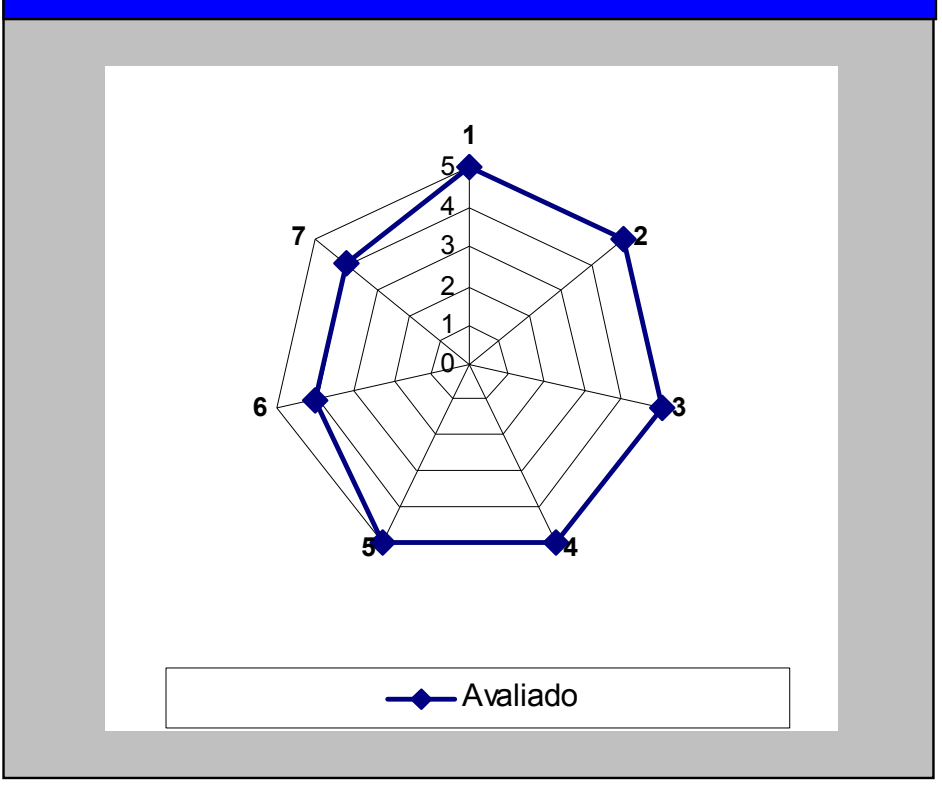

Fonte - Elaborada pelo autor 


\subsubsection{Estruturação}

\subsection{Organização}

O objeto de estudo possui uma organização de aquisições e riscos descentralizada e dedicada exclusivamente para o projeto. Na parte de riscos do projeto existem 3 profissionais, sendo um gerente de riscos e 2 analistas de riscos. Além disto, existe um comitê do projeto onde existe a figura de um especialista/auditor de riscos. $\mathrm{Na}$ área de aquisições não existe um representante dedicado para a análise e gestão dos riscos das aquisições. Os riscos do projeto referentes à aquisição são de responsabilidade do coordenador de suprimentos e contratos, que reporta mensalmente o andamento das ações para o gerente de riscos do projeto. Cada processo de aquisição com valor superior a US\$ 1 milhão recebe uma análise de riscos de aquisições pelo respectivo comprador como parte do processo de contratação. Riscos dentro de uma determinada criticidade são reportados aos níveis gerenciais para uma análise mais detalhada e reportados ao gerente de riscos do projeto. A figura 21 abaixo mostra a estrutura organizacional do projeto.

Figura 21 - Estrutura organizacional típica - caso A

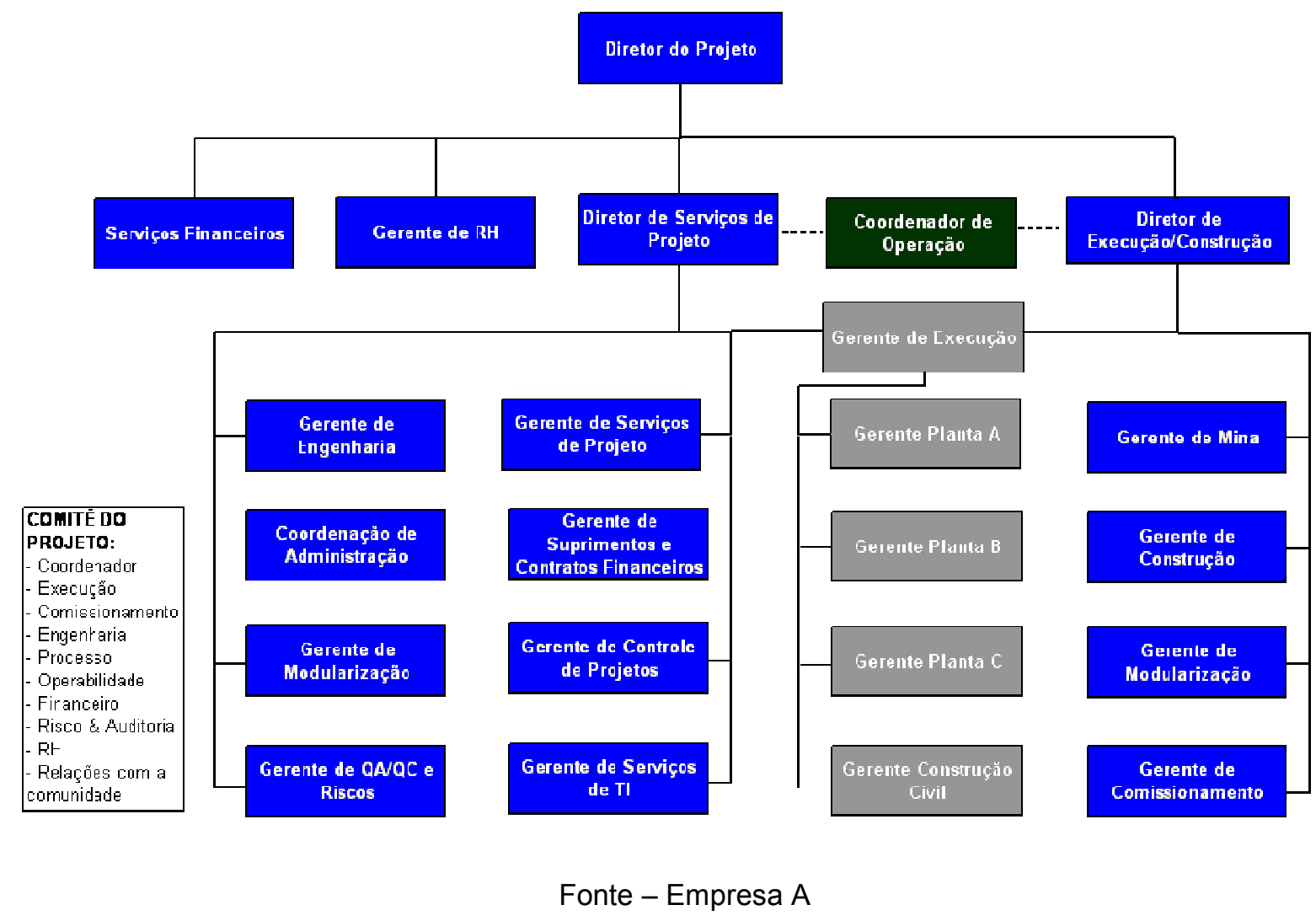




\subsection{Processos}

No objeto de estudo o gerenciamento de riscos do projeto atua de forma integrada em todo o ciclo de aquisições deste o planejamento até a gestão e encerramento dos contratos. Conforme mostra a figura 22 na fase de planejamento das aquisições é realizada a estratégia das aquisições para o projeto, coordenada pela área de suprimentos e contratos com o envolvimento das partes interessadas do projeto. Para elaboração das estratégias de aquisições utiliza-se das informações da análise de riscos do projeto. As estratégias de aquisição são então recomendadas para os níveis gerenciais da empresa para aprovação. Uma vez aprovadas, a área de engenharia trabalha na elaboração e emissão das requisições técnicas de acordo com as estratégias de aquisição definidas.

Figura 22 - Estrutura do gerenciamento de riscos das aquisições - caso A

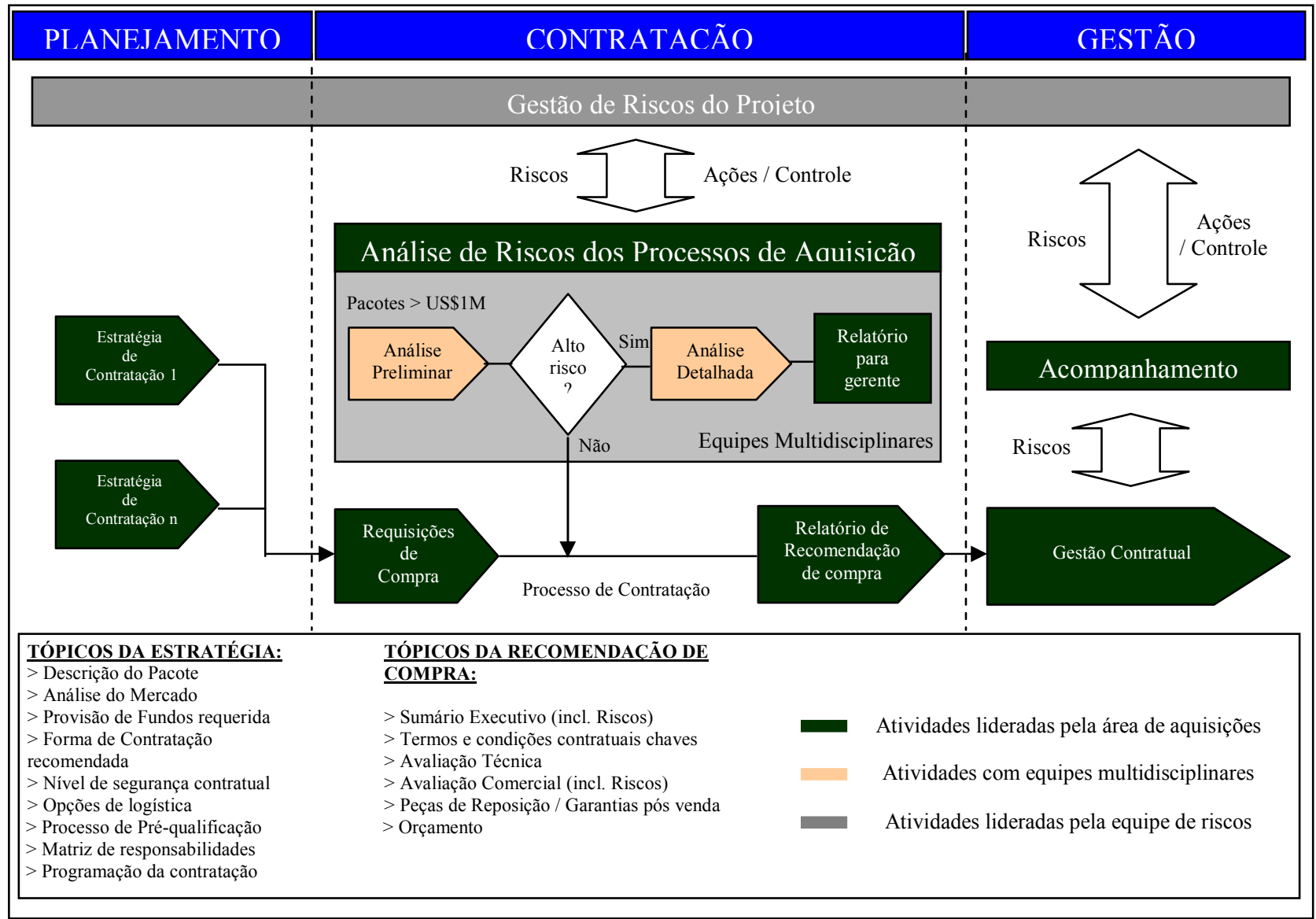

Fonte - Empresa A

A requisição técnica depois de elaborada passa pelos processos definidos de aprovação interna e chega à área de suprimentos e contratos para início do 
processo de contratação. Nesta fase os processos de contratação com valores superiores a US\$ 1 milhão, passam por uma análise de riscos qualitativa específica das aquisições. $\mathrm{Na}$ fase preliminar o comprador com suporte das áreas de engenharia e construção realiza uma avaliação dos riscos envolvidos na aquisição, baseados em um questionário simplificado fazendo a adequação das respostas de acordo com uma matriz de probabilidade $\mathrm{x}$ impacto conforme indicado na figura 23.

Figura 23 - Matriz de probabilidade $\mathrm{x}$ impacto - caso A

\begin{tabular}{|c|c|c|c|c|c|c|c|c|}
\hline & & & \multicolumn{5}{|c|}{ CONSEQUENCIAS } & \\
\hline & & & Insignificante & Pequena & Moderada & Grande & Catastrófica & \\
\hline & & & \multicolumn{5}{|c|}{ IMPACTO RELATIVO A CUSTOS } & \\
\hline & & & $\$<200 \mathrm{~K}$ & $\$ 200-5 \mathrm{M}$ & $\$ 5 M-25 M$ & $\$ 25 \mathrm{M}-100 \mathrm{M}$ & $\$>100 \mathrm{M}$ & \\
\hline & & & 1 & 2 & 3 & 4 & 5 & \\
\hline \multirow{5}{*}{ 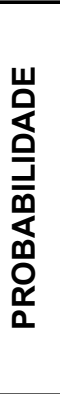 } & $\begin{array}{c}\text { Quase Certa } \\
80-100 \%\end{array}$ & 5 & M (5) & S (10) & S (15) & $\mathrm{H}(20)$ & $\mathrm{H}(25)$ & \multirow{5}{*}{ 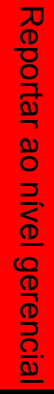 } \\
\hline & $\begin{array}{c}\text { Muito provável } \\
60-80 \% \\
\end{array}$ & 4 & M (4) & S (8) & $S(12)$ & $\mathrm{H}(16)$ & $\mathrm{H}(20)$ & \\
\hline & $\begin{array}{l}\text { Provável } \\
40-60 \% \\
\end{array}$ & 3 & $\mathrm{~L}(3)$ & $M(6)$ & $\mathrm{S}(9)$ & $H(12)$ & $H(15)$ & \\
\hline & $\begin{array}{c}\text { Pouco provável } \\
20-40 \% \\
\end{array}$ & 2 & $L(2)$ & M (4) & $M(6)$ & S (8) & $\mathrm{H}(10)$ & \\
\hline & $\begin{array}{c}\text { Raro } \\
0-20 \% \\
\end{array}$ & 1 & $\mathrm{~L}(1)$ & $L(2)$ & $L(3)$ & M (4) & $H(5)$ & \\
\hline
\end{tabular}

Risco Baixo - Gerenciar através de procedimentos de rotina / atividades Risco Moderado - Foco na identificação / implementação de controles

Risco Significante - Suporte requerido de nível Sênior para identificar / implementar controles

Risco Alto - (Escalar o assunto para o nível gerencial) - reportar para nível executivo para mitigação

$$
\text { Fonte - Empresa A }
$$

Processos avaliados com alto risco na fase preliminar são submetidos a uma análise de riscos mais detalhada com o envolvimento de equipes multidisciplinares. A análise de riscos detalhada é também qualitativa, sendo ao final do processo gerado um relatório de riscos o qual é reportado para a área de gestão de riscos do projeto para implementação de ações e controles.

No relatório de recomendação de compras elaborado pela área de aquisições são incorporados os resultados e ações mitigadoras do processo de riscos das aquisições do processo de contratação. 
Durante a fase de gestão contratual os riscos e ações relativos às aquisições de responsabilidade da área de suprimentos e contratos, são acompanhados pelo gerente da área e reportados para a área de gestão de riscos do projeto.

A área de gestão de riscos faz o monitoramento e controle dos riscos e periodicamente existem auditorias de riscos realizadas pelo comitê do projeto para verificação do andamento das ações e situação dos riscos do projeto.

Para avaliação dos pontos fortes, pontos em desenvolvimento e não desenvolvidos da empresa $A$ com relação a sua atuação na gestão de riscos aplicados na aquisição de bens e serviços para projetos de capital utilizou-se dos resultados do questionário das práticas operacionais da empresa $\mathrm{A}$ construído com base na teoria e cujos resultados estão descritos na tabela 14 .

Tabela 14 - Resumo dos resultados dos processos de riscos das aquisições - caso A

\begin{tabular}{|c|c|c|c|}
\hline Processos & Pontos Fortes & Pontos em desenvolvimento & Pontos näo desenvolvidos \\
\hline Planejamento de riscos & $\begin{array}{l}\text { - Procedimento estabelecido para riscos das } \\
\text { aquisiçôes } \\
\text { - Envolvimento das partes interessadas } \\
\text { - Treinamento de equipes envolvidas } \\
\text { - Facilitadores } \\
\text { - Estrutura organizacional }\end{array}$ & $\begin{array}{l}\text { - Funçốes e responsabilidades } \\
\text { - Provisẩo de orçamento e inclusão no } \\
\text { cronograma do projeto } \\
\text { - Definiçẫo das categorias de riscos } \\
\text { - Alinhamento com os objetivos do projeto }\end{array}$ & \\
\hline Identificaçăo de riscos & - Abrangência da análise de riscos & $\begin{array}{l}\text { - Análise das incertezas nas premissas do } \\
\text { projeto com impacto em suprimentos } \\
\text { - Estrutura analítica de riscos } \\
\text { - Suporte para a identificação dos riscos }\end{array}$ & - Análise de oportunidades \\
\hline Análise qualitativa & $\begin{array}{l}\text { - Matriz de probabilidade x impacto } \\
\text { - Análise da probabilidade e impactos } \\
\text { - Registro de riscos }\end{array}$ & $\begin{array}{l}\text { - Definiçẫo de tolerância a riscos das partes } \\
\text { interessadas }\end{array}$ & $\begin{array}{l}\text { - Categorizaçăo de riscos com baixa } \\
\text { qualidade de informaçốes }\end{array}$ \\
\hline Análise quantitativa & & & - Análise quantitativa de riscos \\
\hline Plano de respostas aos riscos & - Abrangência das respostas & $\begin{array}{l}\text { - Definiçã̃o dos envolvidos nas respostas } \\
\text { - Realimentaçã̃o dos resultados de riscos } \\
\text { para outras áreas } \\
\text { - Utilizaçẫo de estratégias contigenciadas } \\
\text { - Realimentação dos resultados de riscos } \\
\text { nas estratégias de aquisiçốes }\end{array}$ & - Respostas para as oportunidades \\
\hline Monitoramento e controle & $\begin{array}{l}\text { - Revisổes e reavaliçốes periódicas } \\
\text { - Atualizaçẫo do registro de riscos }\end{array}$ & $\begin{array}{l}\text { - Acompanhamento da eficência das } \\
\text { respostas } \\
\text { - Controle de mudanças do projeto } \times \text { Riscos }\end{array}$ & \\
\hline
\end{tabular}

Fonte - Elaborada pelo autor

\subsubsection{Estrutura analítica de riscos típica}

A empresa A utiliza uma estrutura analítica de riscos de aquisições do projeto, dividida em riscos das aquisições de contratos e outra para riscos de suprimentos. 


\section{A tabela 15 mostra a estrutura analítica de riscos utilizada para contratos.}

Tabela 15 - Estrutura analítica de riscos de contratos - caso A

\section{EMPRESA A}

\section{Estrutura Analítica de Riscos}

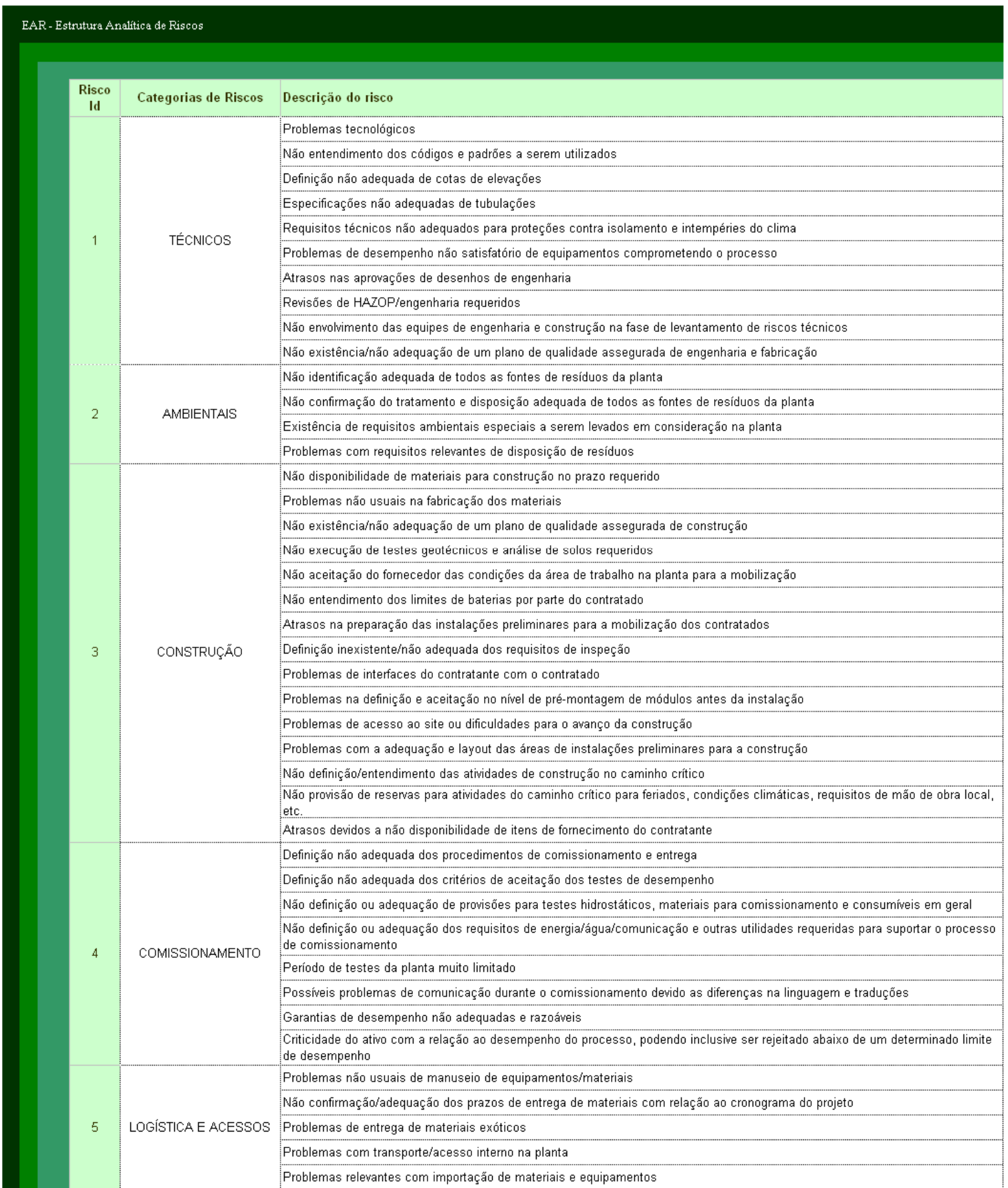


EMPRESA A

Estrutura Analítica de Riscos

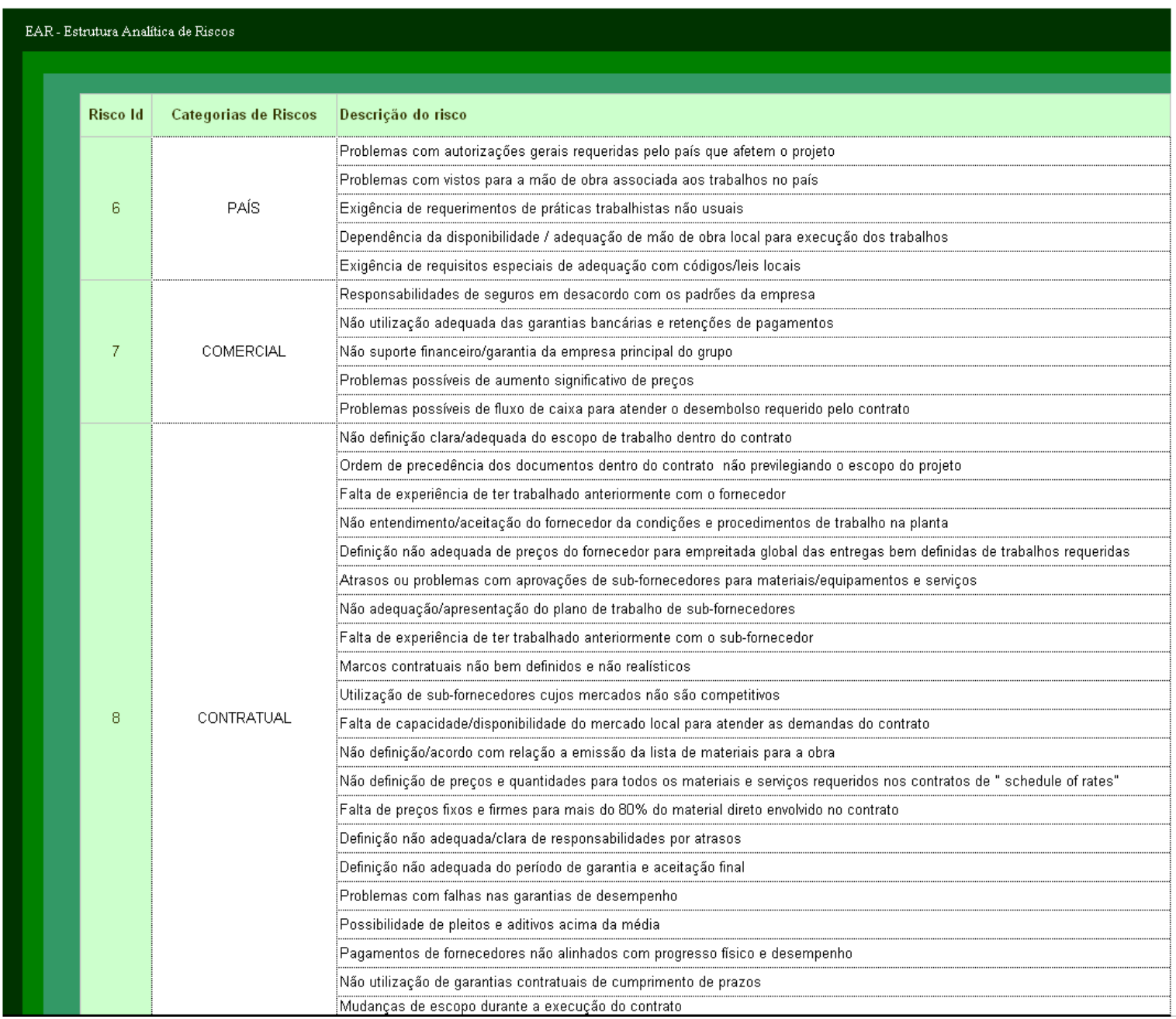

\section{Fonte - Empresa A}




\section{A tabela 16 mostra a estrutura analítica de riscos utilizada para suprimentos.}

Tabela 16 - Estrutura analítica de riscos de suprimentos - caso A

\section{EMPRESA A $\quad$ Estrutura Analítica de Riscos}

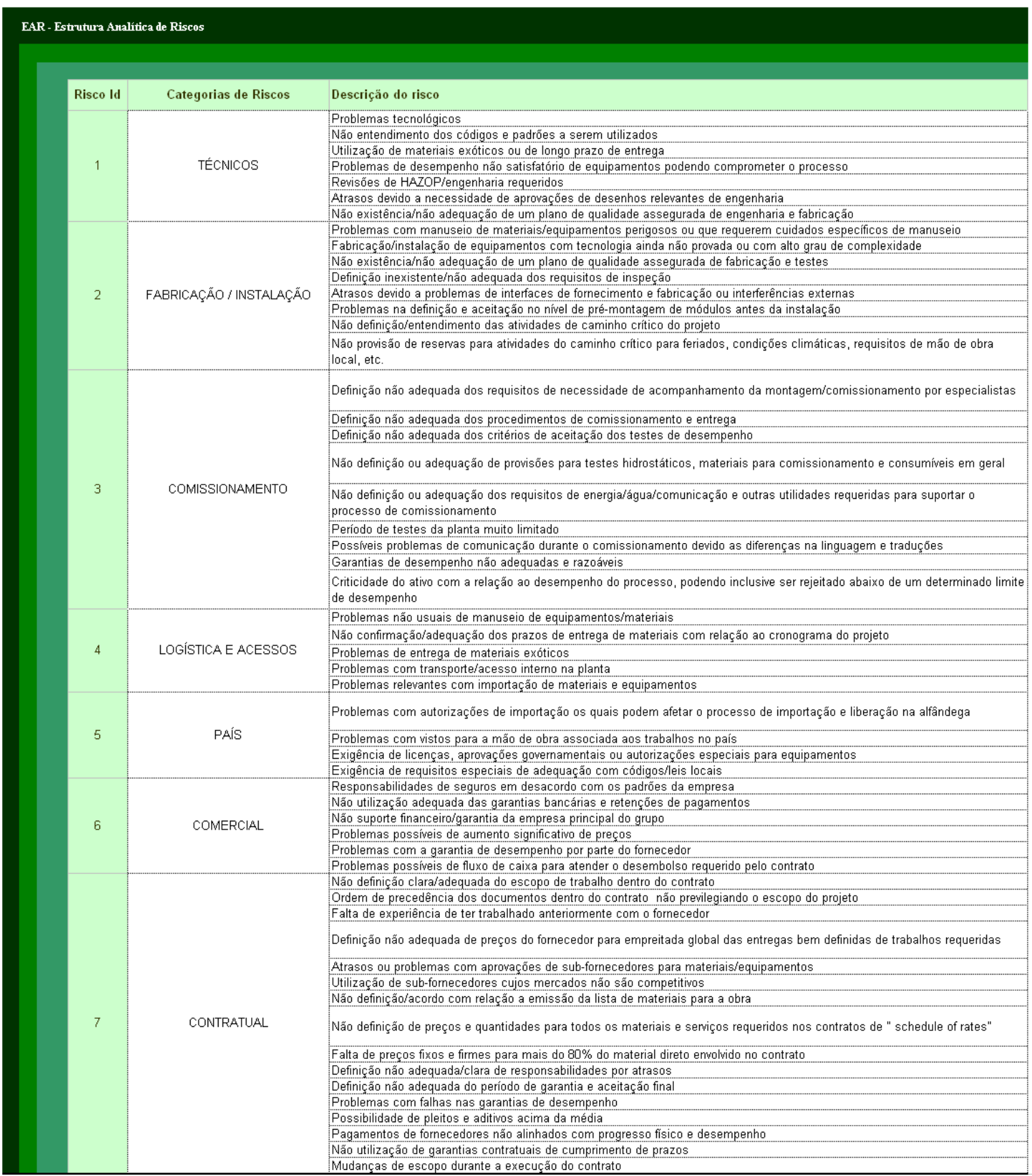

Fonte - Empresa A 


\subsubsection{Categorias de riscos mais relevantes}

Dentre as categorias de riscos descritas nas estruturas analíticas de riscos da empresa $A$ aquelas com uma maior relevância para o objeto de pesquisa identificado foram:

\section{CONTRATOS}

- Riscos técnicos

- Riscos de construção

- Riscos do País

\section{SUPRIMENTOS}

- Riscos de Logística

- Riscos comerciais

No nível de contratos, a identificação da categoria de riscos técnicos como relevante foi devido à utilização de tecnologias ainda em desenvolvimento. Para a categoria de construção foi devido à localização da obra e restrições de mão de obra. Já para a categoria de riscos do país, foram devido a exigências específicas de comunidades locais, questões de disponibilidade/capacidade da mão de obra local e outros requisitos especiais do país.

No nível de suprimentos, a identificação da categoria de logística como relevante foi devido à necessidade de transporte e criticidade do manuseio de módulos enormes de equipamentos e sistemas. Para a categoria de riscos comerciais foi devido à utilização de uma grande quantidade de materiais especiais e sujeitos a grandes aumentos de preços.

A empresa A também mencionou que a relevância dos riscos pode variar em função da fase do processo de aquisição. 


\subsubsection{Lições aprendidas}

Segundo as entrevistas realizadas na empresa A, o processo de gestão de riscos precisa ter o comprometimento de todas as pessoas envolvidas e a decisão dos níveis gerenciais da empresa de fazê-lo. Através da incorporação dos procedimentos de riscos da aquisição nos processos de aquisição e através da organização de uma área específica para gestão dos riscos gerais do projeto, bem como através de auditorias periódicas lideradas pelo comitê do projeto, percebeu-se um maior comprometimento das pessoas envolvidas no projeto com o processo de riscos.

O processo de riscos é muito dinâmico, sendo necessária além de uma equipe dedicada, a utilização de um sistema dedicado para acompanhamento e atualização dos riscos.

\subsubsection{Práticas complementares}

A empresa $A$ incorpora de forma detalhada e muito clara os resultados dos riscos das aquisições e das ações mitigadoras, prevenção e transferência no relatório de recomendação da compra, de forma que o executivo que vai aprovar a recomendação tenha todos os subsídios para a tomada de decisão. Este tipo de procedimento contribui para a transparência do processo de aquisição, principalmente quando os valores envolvidos e a complexidade da aquisição são altos.

Existe um sistema que faz o armazenamento e rastreamento de toda a documentação envolvida no processo de aquisição facilitando o processo de auditorias e também dando transparência ao processo de aquisição.

Embora o projeto seja desenvolvido e executado através do escritório de gerenciamento de projetos na Austrália, o escritório corporativo de gerenciamento de projetos da empresa no Canadá faz auditorias semestrais no projeto e reporta os resultados para a equipe de projetos na Austrália e para os níveis corporativos da empresa. 


\subsection{Caso B}

\subsubsection{Objeto}

A empresa estudada é uma empresa do segmento de mineração, contando com escritórios e plantas industriais em várias partes do mundo. $O$ faturamento mundial em 2006 alcançou cerca de US\$ 26 bilhões. A empresa B possui um escritório de gerenciamento de projetos que define os padrões de engenharia, coordena a análise de riscos dos projetos, faz o acompanhamento da execução e mantêm as melhores práticas e lições aprendidas dos projetos da empresa. A carteira de projetos da empresa atual é da ordem de US $\$ 30$ bilhões, sendo o valor médio dos projetos estratégicos da ordem de US $\$ 500$ milhões e a duração típica dos projetos de 4 a 6 anos.

\subsubsection{Metodologia}

Para este caso o pesquisador teve também a oportunidade de interagir com as equipes de gerenciamento de projetos e aquisições buscando capturar ainda mais informações suficientes para análise detalhada do caso.

\subsubsection{Gerenciamento de riscos das aquisições na empresa B}

\subsubsection{Reconhecimento da importância}

A figura 24 mostra que o objeto de estudo do caso B, possui uma alta aderência aos níveis mínimos de processos requeridos para a utilização e aplicação do gerenciamento de riscos aplicados nas aquisições de bens e serviços. A empresa $B$ possui um procedimento corporativo de gerenciamento de riscos de projetos, incluindo também procedimento específico para os riscos envolvidos nas aquisições, capacita os envolvidos no processo de riscos, possui procedimentos corporativos para as aquisições utilizando-se de métricas para medir o desempenho das aquisições, centraliza as melhores práticas de gerenciamento de projetos em um escritório de projetos e utiliza parte dos resultados de riscos para revisão das estratégias das aquisições. Mais adiante se descreve em detalhes o processo, comprovando a importância dada pela empresa B ao gerenciamento de riscos das aquisições. 
Figura 24 - Importância do gerenciamento de riscos das aquisições - caso B

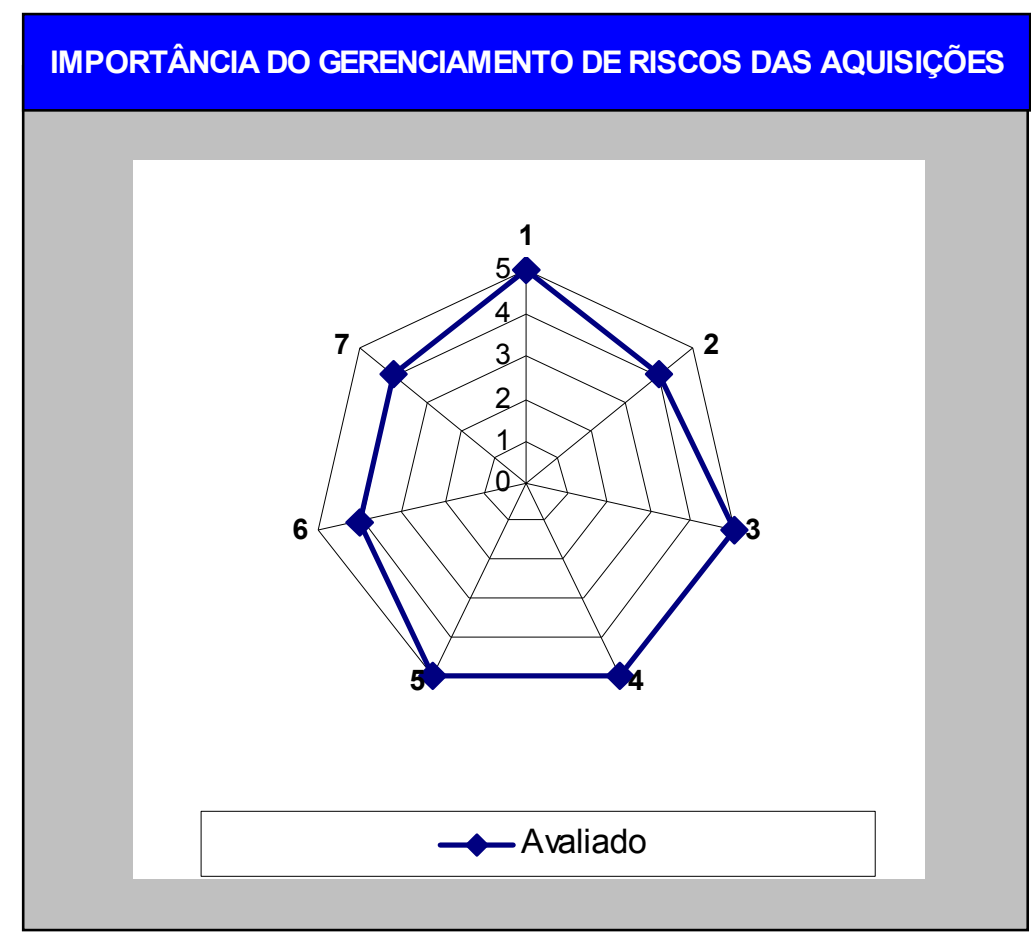

Fonte - Elaborada pelo autor

\subsubsection{Estruturação}

\subsection{Organização}

A empresa B possui uma estrutura organizacional com a área de aquisição e escritório de gerenciamento de projetos centralizado para atender a demanda dos projetos das unidades de negócios. Outras áreas de suporte também são centralizadas, tais como: segurança e meio ambiente, comunicação, relações institucionais, serviços de $\mathrm{Tl}$, automação e controle e recursos humanos. A estrutura de gerenciamento dos projetos está sob a coordenação da própria unidade de negócio. $O$ processo de análise de riscos para as aquisições de bens e serviços é realizado apenas para os projetos estratégicos da empresa $B$, sendo a responsabilidade de execução da área de planejamento e inteligência de suprimentos. Da mesma forma para os projetos estratégicos da empresa é realizada uma análise de riscos do projeto pela área de engenharia de riscos. A figura 21 mostra a estrutura organizacional típica da empresa B. 
Figura 25 - Estrutura organizacional típica - caso B

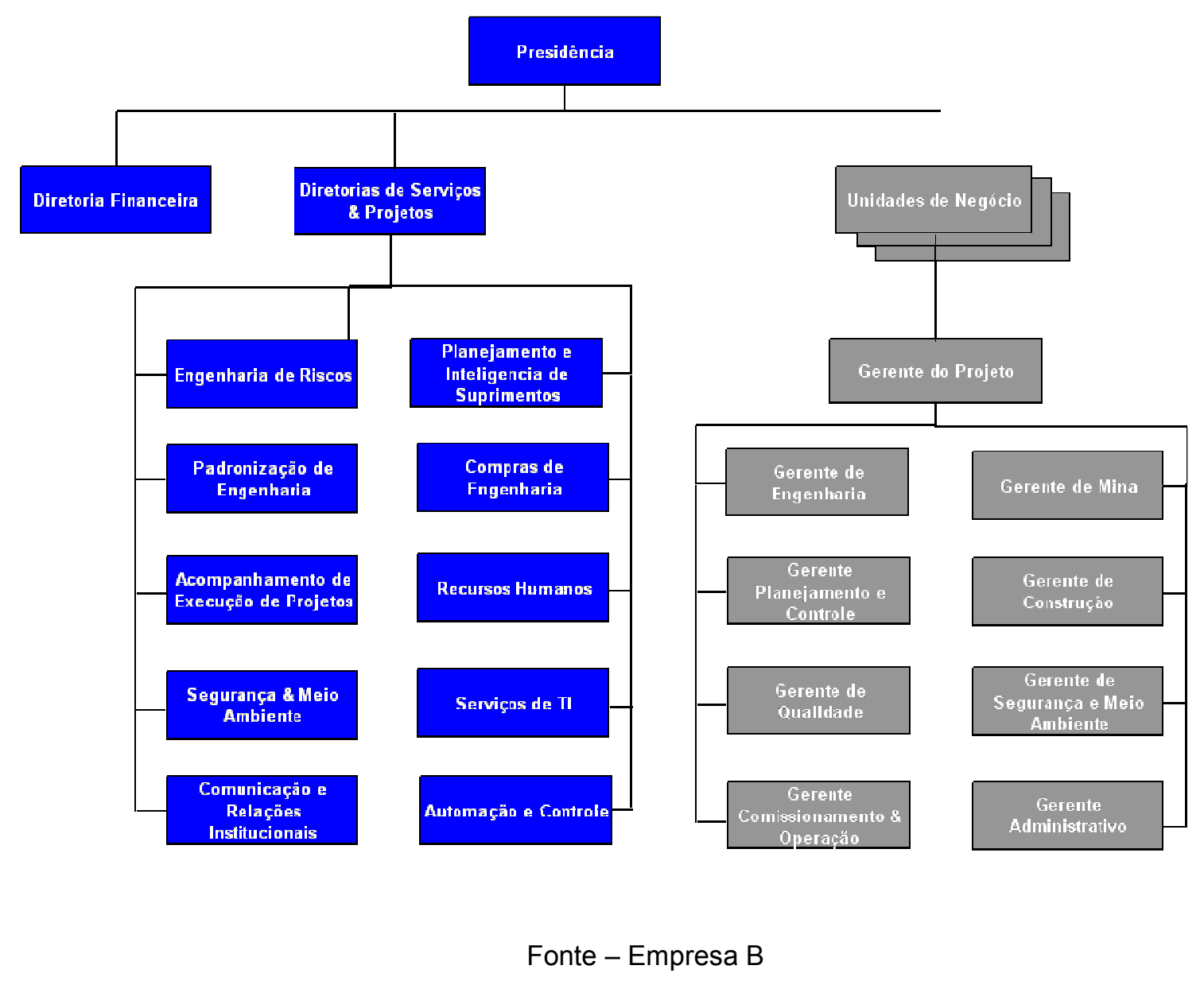

\subsection{Processos}

A empresa B desenvolve os seus projetos utilizando a metodologia do IPA (Independent Project Analysis), na qual o projeto é progressivamente desenvolvido em fases de planejamento (análise do negócio, seleção de alternativas e planejamento da construção) até a sua aprovação e início da execução. A análise de riscos para os projetos é realizada a partir da seleção de alternativas e a análise de riscos das aquisições na fase de planejamento da construção. As estratégias das aquisições são iniciadas a partir da seleção de alternativas quando se tem a rota de processo definida e é concluída na fase de planejamento da construção. O processo de gestão de riscos das aquisições é integrado ao processo de gestão de riscos do projeto, embora seja coordenado por diferentes áreas devido à estrutura organizacional da empresa B. 
A figura 26 mostra de forma geral a metodologia de riscos das aquisições de bens e serviços utilizados na empresa $B$.

Figura 26 - Metodologia de gerenciamento de riscos das aquisições - caso B

\section{Visão Geral da Metodologia}

\section{PLANO DE SUPRIMENTOS}

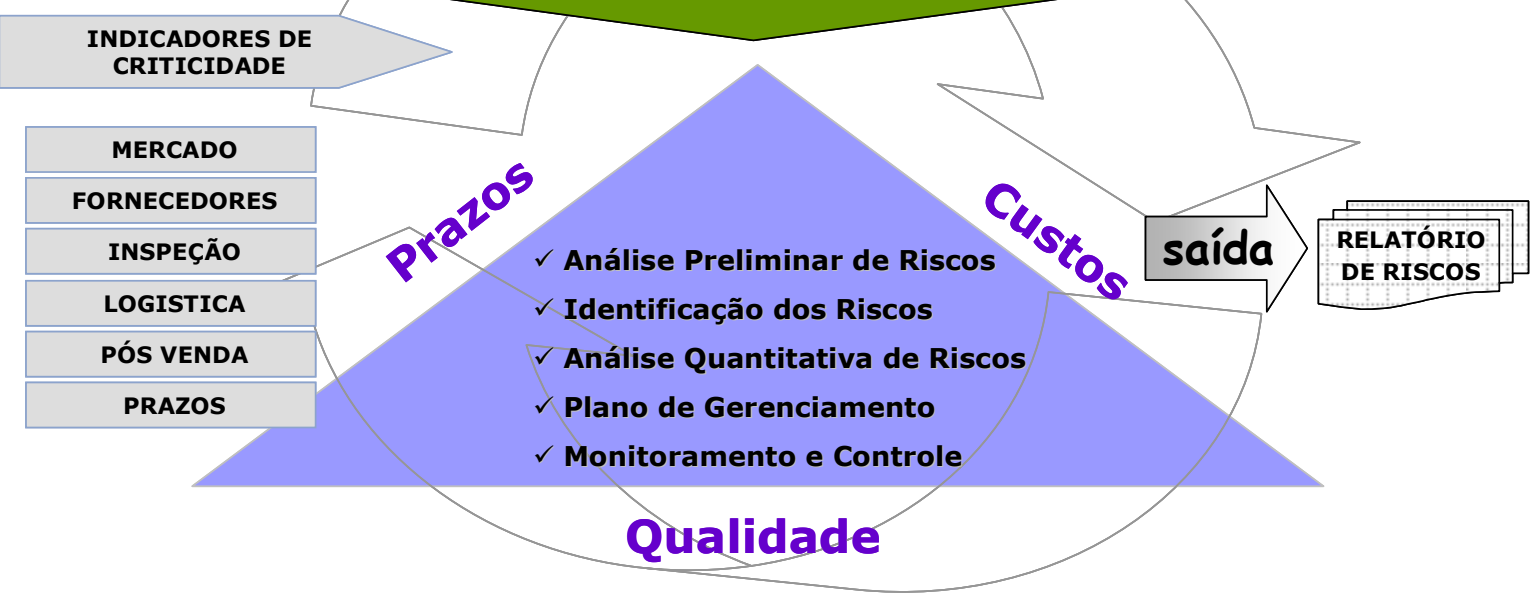

Fonte - Empresa B

Mantendo o mesmo padrão da estrutura dos processos entre os casos para facilitar uma análise crítica, o autor mostra na figura 27 a estruturação dos processos da empresa B. Uma grande parte dos esforços de análise de riscos é realizada na fase de planejamento. Nesta fase os resultados da análise de riscos do projeto realizadas na fase de análise das alternativas são utilizados como entrada para o processo de estratégias de contratações. Estas estratégias de contratações geram como saídas os pacotes de contratação, os quais são submetidos ao processo de análise preliminar de riscos das aquisições. Esta análise preliminar é feita para todos os pacotes relevantes com soma de valores totais de até $80 \%$ do valor das compras do projeto. Esta análise preliminar consiste na identificação de características de criticidade para cada pacote nas dimensões mercado, fornecedores, inspeção, logística, pós venda e prazos. Os pacotes mais críticos, normalmente os 10 mais relevantes são submetidos a uma análise detalhada de riscos utilizando métodos quantitativos com simulações para adequação dos riscos, com a elaboração de um plano de respostas e definições de monitoramento e controle. Toda a análise de 
riscos das aquisições é liderada pela área de planejamento de suprimentos da empresa B com a participação de equipes multidisciplinares. Os resultados finais realimentam as estratégias de contratação e a gestão de riscos do projeto. Nas estratégias finais de contratação, existe um tópico específico para os riscos envolvidos nas aquisições e cada pacote possui um identificador do nível de risco e do número do plano de ação para aqueles com alto grau de risco.

$\mathrm{Na}$ fase de contratação e gestão dos contratos toda a responsabilidade pelo acompanhamento e gestão do projeto passa para a equipe da unidade de negócio. $\mathrm{Na}$ fase de contratação as compras são realizadas de forma centralizada pela área de compras de engenharia.

Figura 27 - Estrutura do gerenciamento de riscos das aquisições - caso B

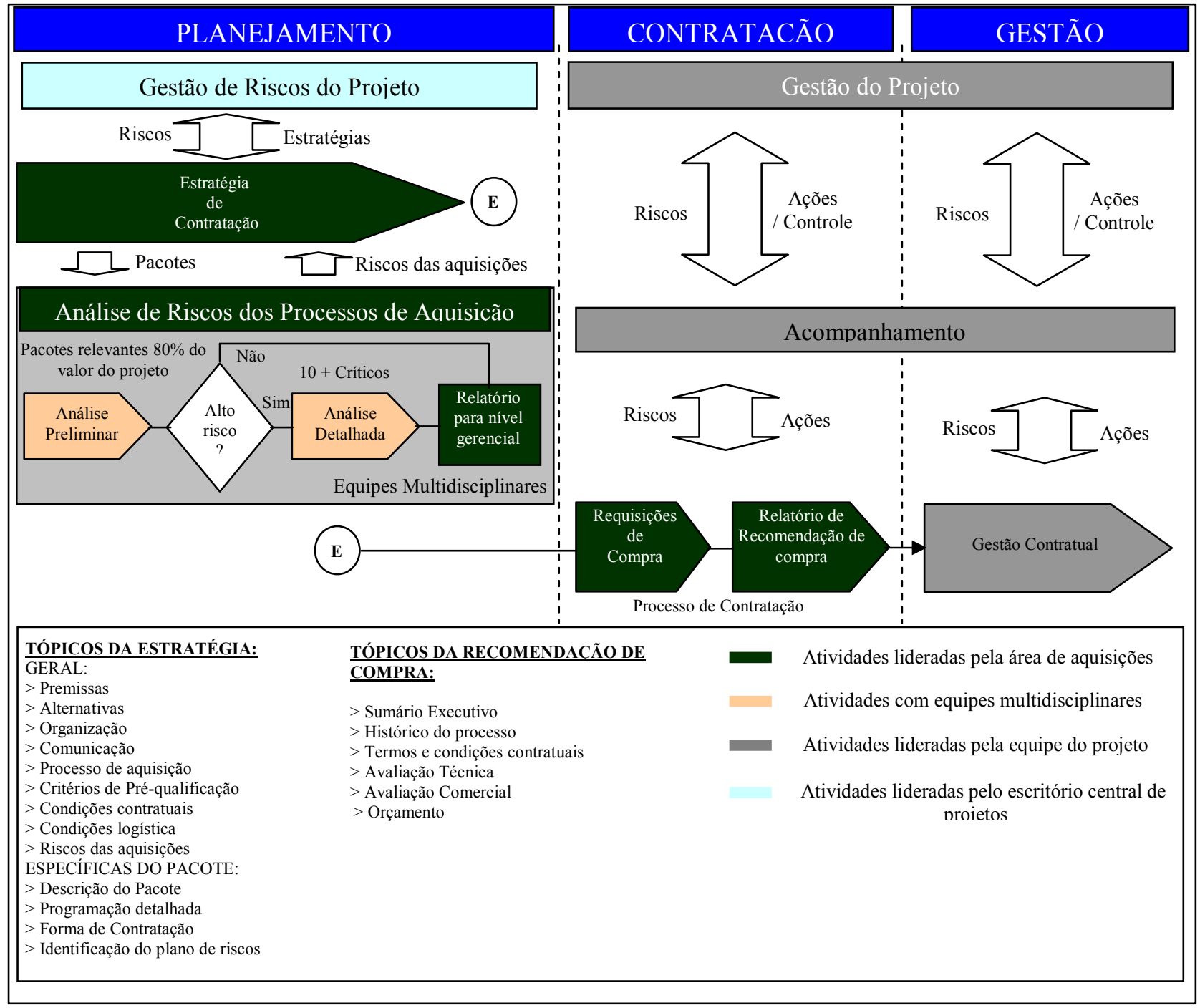


A execução dos projetos é auditada pela área do escritório de gerenciamento de projetos responsável pelo acompanhamento da execução dos projetos na empresa B.

Um resumo dos resultados das entrevistas e do questionário com a identificação dos pontos fortes, em desenvolvimento e não desenvolvidos dos processos na empresa B estão indicados na tabela 17 abaixo:

Tabela 17 - Resumo dos resultados dos processos de riscos das aquisições - caso B

\begin{tabular}{|c|c|c|c|}
\hline Processos & Pontos Fortes & Pontos em desenvolvimento & Pontos näo desenvolvidos \\
\hline Planejamento de riscos & $\begin{array}{l}\text { - Procedimento estabelecido para riscos das } \\
\text { aquisiçôes } \\
\text { - Facilitadores }\end{array}$ & $\begin{array}{l}\text { - Funçôes e responsabilidades } \\
\text { - Provisăo de orçamento e inclusăo no } \\
\text { cronograma do projeto } \\
\text { - Definiçẫo das categorias de riscos } \\
\text { - Alinhamento com os objetivos do projeto } \\
\text { - Envolvimento das partes interessadas } \\
\text { - Treinamento de equipes envolvidas }\end{array}$ & - Estrutura organizacional \\
\hline Identificação de riscos & - Abrangência da análise de riscos & $\begin{array}{l}\text { - Análise das incertezas nas premissas do } \\
\text { projeto com impacto em suprimentos } \\
\text { - Estrutura analítica de riscos } \\
\text { - Suporte para a identificaçäo dos riscos }\end{array}$ & - Análise de oportunidades \\
\hline Análise qualitativa & & $\begin{array}{l}\text { - Matriz de probabilidade } x \text { impacto } \\
\text { - Análise da probabilidade e impactos } \\
\text { - Registro de riscos }\end{array}$ & $\begin{array}{l}\text { - Definiçã̃o de tolerância a riscos das } \\
\text { partes interessadas } \\
\text { - Categorizaçẫo de riscos com baixa } \\
\text { qualidade de informaçôes }\end{array}$ \\
\hline Análise quantitativa & - Análise quantitativa de riscos & $\begin{array}{l}\text { - Suporte de especialistas } \\
\text { - Uso de ferramentas e técnicas de análise } \\
\text { quantitativa } \\
\text { - Simulação para atender limites partes } \\
\text { interessadas }\end{array}$ & \\
\hline Plano de respostas aos riscos & & $\begin{array}{l}\text { - Definição dos envolvidos nas respostas } \\
\text { - Realimentaçẫo dos resultados de riscos } \\
\text { para outras áreas } \\
\text { - Realimentaçẫo dos resultados de riscos } \\
\text { nas estratégias de aquisiçốes }\end{array}$ & $\begin{array}{l}\text { - Abrangência das respostas } \\
\text { - Respostas para as oportunidades } \\
\text { - Utilização de estratégias contigenciadas }\end{array}$ \\
\hline Monitoramento e controle & & & $\begin{array}{l}\text { - Revisőes e reavaliçôes periódicas } \\
\text { - Atualizaçẫo do registro de riscos } \\
\text { - Acompanhamento da eficência das } \\
\text { respostas } \\
\text { - Controle de mudanças do projeto } \times \text { Riscos }\end{array}$ \\
\hline
\end{tabular}

Fonte - Elaborada pelo autor

\subsubsection{Estrutura analítica de riscos típica}

A empresa B utiliza tipicamente uma estrutura analítica de riscos das aquisições para os projetos de bens de capital, conforme indicado na tabela 18. 


\section{EAR - Estrutura Analítica de Riscos}

\begin{tabular}{|c|c|c|}
\hline $\begin{array}{l}\text { Risco } \\
\text { Id }\end{array}$ & Categoria de riscos & Descriçäo do risco \\
\hline \multirow{4}{*}{1} & \multirow{4}{*}{ EQUIPE DE IMPLANTAÇת̃̃O } & Atraso na mobilizaçẫo da equipe do contratante \\
\hline & & Atraso na mobilizaçẫo da equipe de Inspeçẩo em fabrica \\
\hline & & Atraso na mobilização da equipe da Gerenciadora \\
\hline & & Atraso na mobilizaçẫo da equipe da contratada devido a falta de mẫo de obra local \\
\hline \multirow{3}{*}{2} & \multirow{3}{*}{ ENGENHARIAA BÁSICA } & $\begin{array}{l}\text { Erissấo das Requisiçốes Técnicas com informaçốes inconsistentes ou incompletas, gerando impactos nas etapas } \\
\text { futuras }\end{array}$ \\
\hline & & Complementaçẩo elou alteraçấo de Escopo \\
\hline & & Atraso na emissấo da Requisiçấo Técnica \\
\hline \multirow{2}{*}{3} & \multirow{2}{*}{ EXPANSÃO FUTURA } & Reprogramaçấo da fabricaçấo em funçấo da autorizaçấo de expansẫo futura \\
\hline & & Reprogramaçấo da execuçấo dos serviços em funçẩo da autorizaçấo de expansấo futura \\
\hline 4 & TECNOLOGIA & Utilizaçấ de tecnologia ainda nẫo provado ou muito complexa \\
\hline \multirow{2}{*}{5} & \multirow{2}{*}{ POLITICA REGIONAL / NACIONAL } & Retrabalho devido ao atendimento inadequado dos fornecedores locais \\
\hline & & Otimizaçẫo de logística \\
\hline 6 & FORNECEDORES & Maior prazo de emissâo do parecer técnico em funçẫo do número de propostas. \\
\hline 7 & RESTRIÇŌES DE CUSTO / PRAZO & Impossibilidade de início dos serviços devido a pendências de outros contratos antecessores. \\
\hline 9 & CONSÓRCIO & Desentendimento entres as empresas que formam o consórcio e matriz de responsabilidade nấo definida \\
\hline 10 & ALÇADA DE APROVAÇÃO & Pacote com alçada máxima de aprovaçấo \\
\hline \multirow{3}{*}{11} & \multirow{3}{*}{ ENGENHARIA DETALHADA } & Atraso na emissấo e análise dos Desenhos dos fornecedores \\
\hline & & Desenhos dos fornecedores incompativeis com o projeto básico \\
\hline & & Erro no calculo estrutural \\
\hline \multirow{2}{*}{12} & \multirow{2}{*}{ MERCADO } & Necessidade de recoletas devido ao vendor list inadequado \\
\hline & & Mercado no limite da capacidade física de fornecimento \\
\hline 13 & MÉTODOS DE EXECUÇẨO & Sequencia executiva da fabricaçẫo nẫo compativel com a montagem \\
\hline \multirow{2}{*}{14} & \multirow{2}{*}{$\begin{array}{l}\text { SAÚDE E SEGURANÇA } \\
\text { OCUPACIONAL }\end{array}$} & Ataque de animais silvestres na equipe mobilizada. \\
\hline & & Ocorrência de epidernia na equipe mobilizada \\
\hline 15 & SEGURANÇA DOS ATIVOS & Roubo de peças / componentes e danos em material já recebidos \\
\hline \multirow[b]{2}{*}{16} & \multirow{2}{*}{ SUE-CONTRATAÇÕES } & Necessidade de autorizaçẫo para subfornecedores \\
\hline & & Má gestẫo dos sub-fornecedores \\
\hline 17 & INSPEÇÃOFISISALLIZAÇÃO & Planejamento e logísticas de inspeçẫo deficientes \\
\hline 18 & LOCALIZAÇÁO E LOGÍSTICA & Nấo conclusâo das estradas de acesso durante o período de entrega dos equipamentos e peças \\
\hline \multirow{2}{*}{19} & \multirow{2}{*}{ ARMAZZENAGEM } & Danificaçấo / perda das peças e componentes \\
\hline & & Dificuldade no rastreamento e localizaçấo das peças e componentes \\
\hline 20 & CONDIÇỐES CLIMÁTICAS & Eaixa produtividade devido a chuvas \\
\hline 21 & ASSISTÊNCIA TÉCNICA & Deficiência na assistência técnica durante a montagem e comissionamento \\
\hline 22 & ADITIVOS / PLEITOS & Nẫo reconhecimento de méritos de aditivos e pleitos gerando paralisaçẫo ejou abandono da obra \\
\hline \multirow{2}{*}{23} & \multirow{2}{*}{ COMISSIONAMENTO / START-UP } & Falta de energia elétrica para o start-up \\
\hline & & Planejamento para o comissionamento e start-up \\
\hline 24 & COMUNIDADE LOCAL & Interrupçâo dos serviços pela comunidade local \\
\hline 25 & $\begin{array}{l}\text { VANDALISMO, GREVE, VIOLÊNCIA } \\
\text { LOCAL }\end{array}$ & Vandalismo, greve, violência local \\
\hline
\end{tabular}




\subsubsection{Categorias de riscos mais relevantes}

Segundo a empresa B a relevância dos riscos depende muito do tipo de contratação (serviço, material, equipamento ou sistema), do grau de tecnologia e novidade envolvidas na aquisição e da localização da obra, porém tipicamente as categorias mais relevantes e que historicamente tem apresentado mais riscos são:

- Engenharia (básica e detalhada): devido à necessidade de velocidade no desenvolvimento dos projetos para atender o mercado e escassez de recursos de qualidade disponíveis, colocando em risco a qualidade das requisições técnicas de compras.

- Segurança, Saúde e Meio Ambiente: devido ao compromisso da empresa B e exigências cada vez maiores de estudos exaustivos por empresas especializadas, comprometendo prazos de início de obra e consequentemente gerando um ambiente propício para problemas de gestão contratuais para atender os prazos de conclusão dos projetos.

- Equipes de Implantação: devido à alta demanda de execução de projetos, gerando problemas de estruturação de equipes qualificadas e integradas e portanto impactando a qualidade dos processos de aquisição e gestão contratuais.

- Mercado e Fornecedores: devido à situação atual de demanda do mercado, gerando mais dificuldades de obtenção dos bens e serviços nos prazos e preços requeridos.

\subsubsection{Lições aprendidas}

Segundo a empresa B o processo de gerenciamento de riscos operacionais para os projetos está estruturado de forma mais organizada apenas há 2 anos e o gerenciamento de riscos específicos para a aquisição de bens e serviços há 1 ano. Segundo os entrevistados é muito pouco tempo para tirar muitas lições até porque o processo ainda continua em desenvolvimento sofrendo melhorias a cada nova aplicação. Porém segundo a empresa B pode-se até então perceber que é necessária a maturidade no gerenciamento de projetos, para a obtenção de bons resultados no gerenciamento de riscos. Outro item importante é a utilização dos resultados de riscos do projeto e aquisições em outras áreas como o cronograma e orçamento do projeto. 
Para obtenção de bons resultados faz-se também necessária uma boa integração do processo de riscos nas várias fases do projeto e o monitoramento e controle adequado dos riscos durante a fase de execução e a empresa B tem encontrado dificuldades devido ao seu porte e a estrutura organizacional.

A utilização de um sistema de suporte para o monitoramento e controle de riscos pode também contribuir para o melhor controle das ações e dinâmica dos riscos.

\subsubsection{Práticas complementares}

Para a seleção dos pacotes mais críticos de aquisição a serem analisados de forma detalhada no processo de gerenciamento de riscos das aquisições, a empresa $B$ utiliza uma matriz de criticidade dos pacotes conforme mostrado na figura 28 abaixo. Esta matriz contém basicamente os pacotes relevantes (aproximadamente $80 \%$ do valor das compras), as características de criticidade dos pacotes e os direcionadores do projeto (prazo, custo e operabilidade). Cada pacote é analisado então por uma equipe multidisciplinar que identifica ou não a aplicabilidade da característica de criticidade. Ao final são contabilizados os pontos de criticidade de cada pacote, baseados na sua pontuação que vai depender também de cada projeto e do seu direcionador.

Figura 28 - Análise preliminar de riscos - caso B

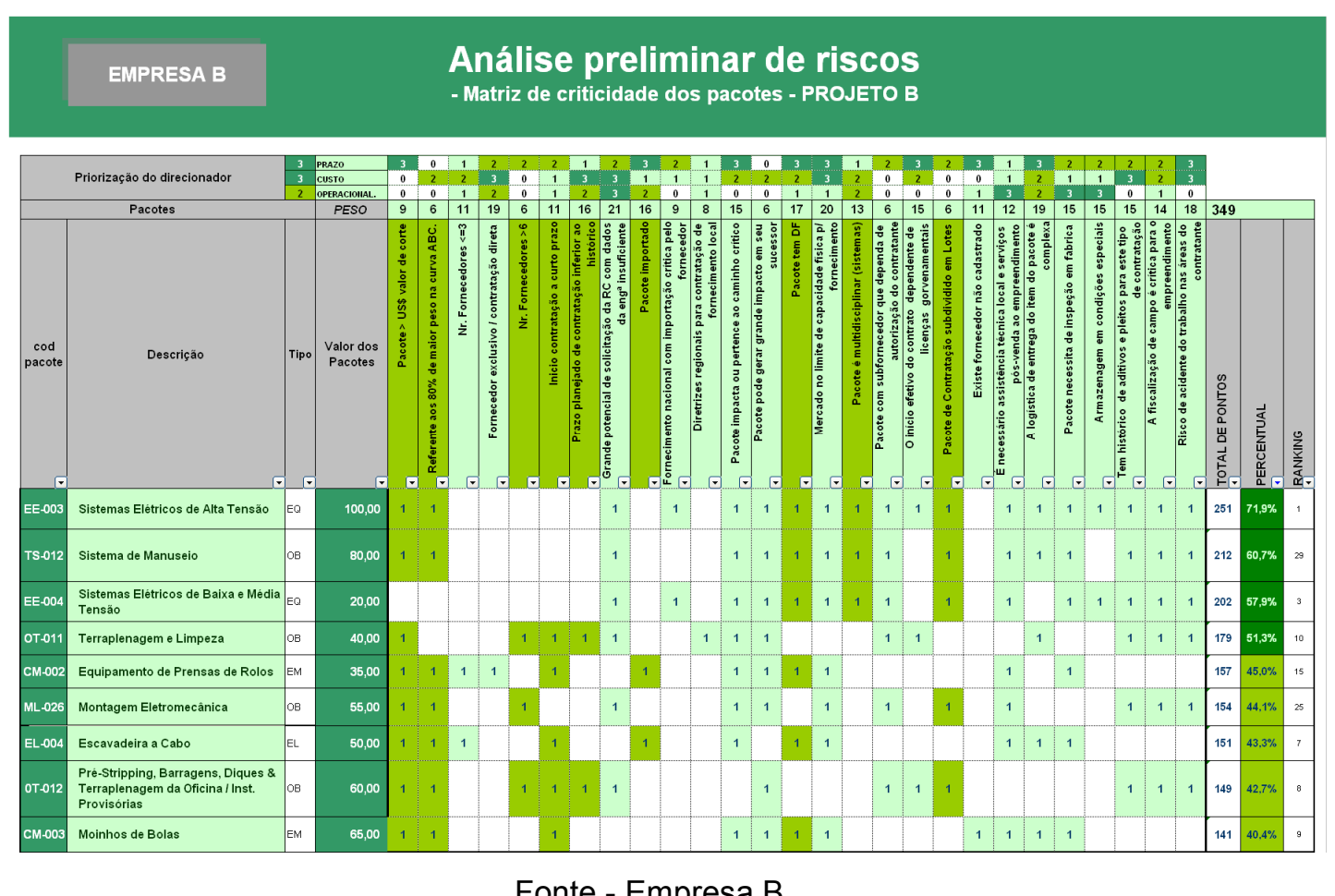

Fonte - Empresa B 
A figura 29 mostra um gráfico com o resultado final de uma análise preliminar de riscos incluindo a pontuação de criticidade do pacote a data da emissão da requisição técnica e o valor do pacote.

Figura 29 - Criticidade dos pacotes de aquisição - caso B

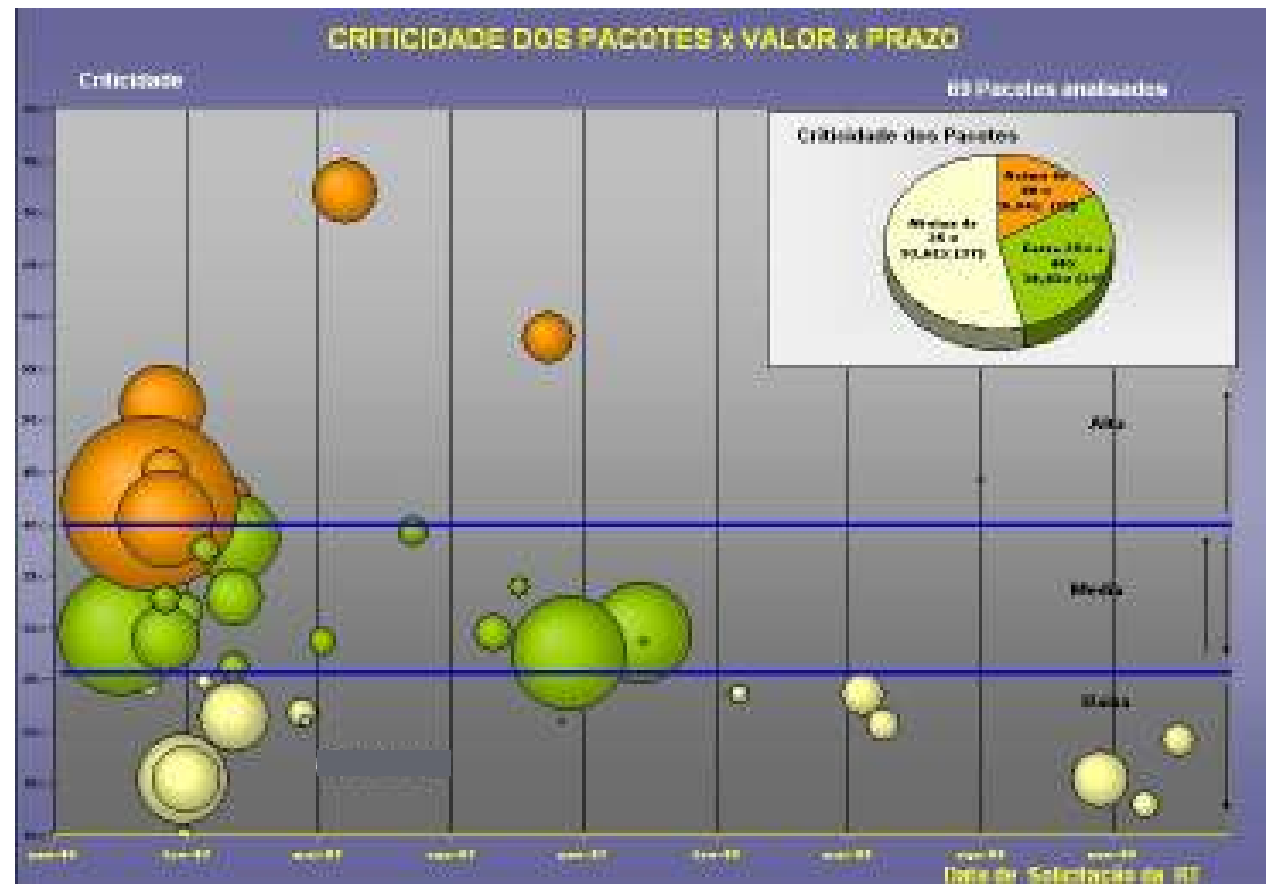

Fonte - Empresa B

Para a seleção final dos pacotes a serem analisados de forma detalhada busca-se ao final um consenso com a equipe multidisciplinar para a definição dos pacotes críticos. Estes pacotes então são submetidos a um processo de identificação de riscos, análise quantitativa, plano de respostas e plano de monitoramento e controle. A figura 30 mostra como exemplo o resultado de uma análise quantitativa de um pacote de aquisição. 
Figura 30 - Análise quantitativa de riscos - caso B

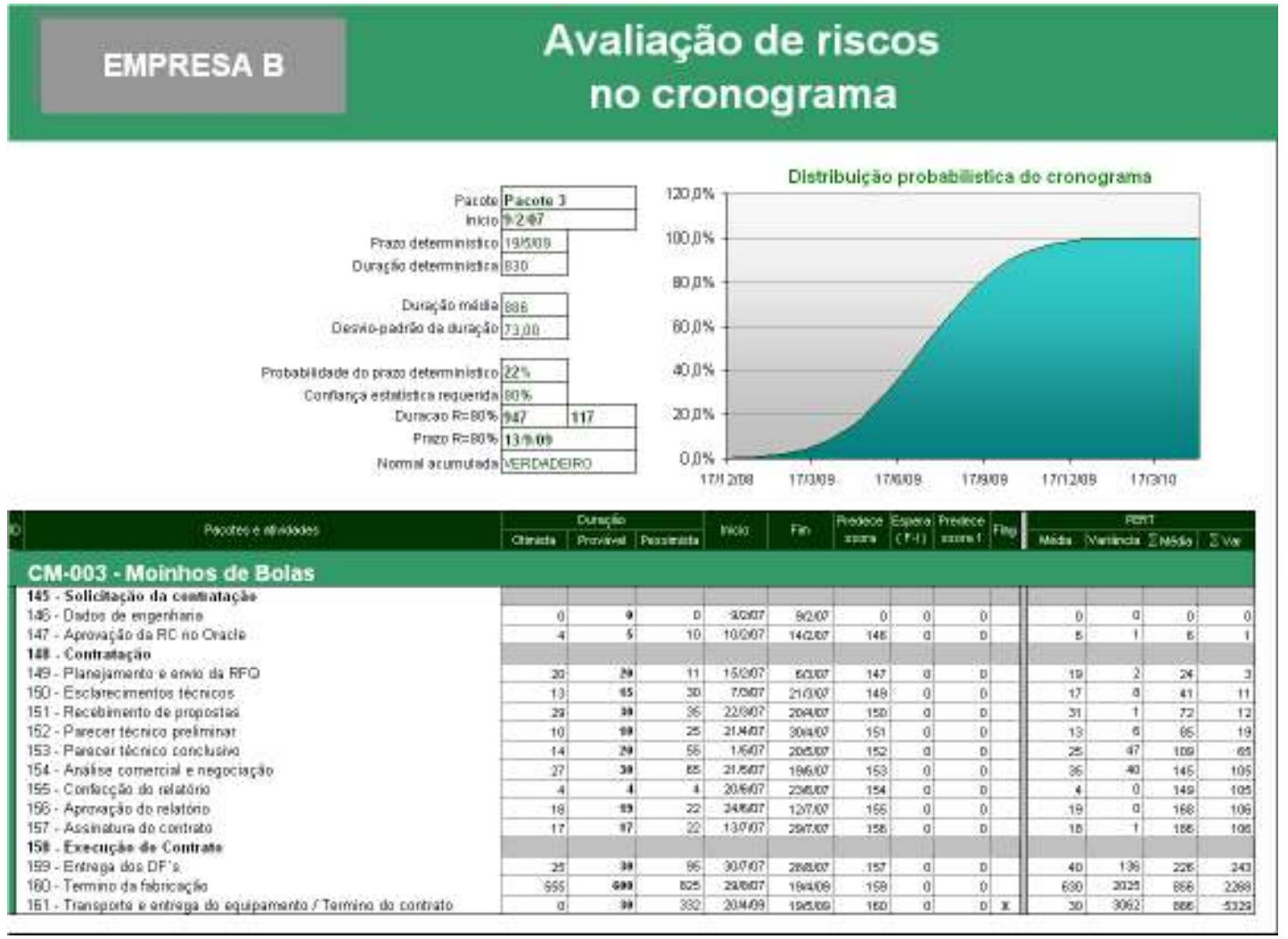

Fonte - Empresa B

Segundo a empresa B estas ferramentas têm contribuído bastante para identificação e mitigação dos riscos das aquisições de bens e serviços para os projetos de bens de capital. 


\subsection{Caso C}

\subsubsection{Objeto}

A empresa estudada é uma empresa brasileira do segmento de óleo e gás, contando com escritórios e plantas industriais em várias partes do Brasil. $O$ faturamento mundial em 2006 alcançou cerca de $R \$ 100$ bilhões. A empresa $C$ possui um escritório de gerenciamento de projetos que define os padrões de engenharia, coordena a análise de riscos dos projetos, faz o acompanhamento da execução e mantêm as melhores práticas e lições aprendidas dos projetos da empresa. A carteira de projetos da empresa atual é da ordem de US\$ 5 bilhões, sendo o valor médio dos projetos estratégicos da ordem de US\$200 milhões e a duração típica dos projetos de 2 a 5 anos.

\subsubsection{Metodologia}

Para este caso o pesquisador identificou dentro do grupo da empresa $C$ uma área de negócios com gerenciamento de projetos mais avançada. Inicialmente foi feito um contato telefônico com o responsável pelo escritório de projetos da empresa com o objetivo de um melhor entendimento de suas atribuições e também foi explicado os objetivos da pesquisa e a estruturação do questionário e da entrevista. Marcou-se então uma reunião para validação do entendimento das respostas do questionário e uma entrevista para captura de outros itens não identificados no questionário. Esta reunião teve duração de 3 horas e contou com a participação de 3 representantes do escritório de projetos.

\subsubsection{Gerenciamento de riscos das aquisições na empresa C}

\subsubsection{Reconhecimento da importância}

A figura 31 mostra que o objeto de estudo do caso $C$, possui uma alta aderência aos níveis mínimos de processos requeridos para a utilização e aplicação do gerenciamento de riscos aplicados nas aquisições de bens e serviços. A empresa $C$ possui um procedimento corporativo de gerenciamento de riscos de projetos, capacita as equipes no gerenciamento de projetos, incluindo programas de certificações PMP, centraliza as melhores práticas de gerenciamento de projetos em um escritório de projetos, possui procedimentos corporativos para as aquisições, e 
está aprimorando a utilização de métricas de desempenho para avaliação dos processos de aquisição. Mais adiante se descreve em detalhes o processo, comprovando a importância dada pela empresa $\mathrm{C}$ ao gerenciamento de riscos das aquisições.

Figura 31 - Importância do gerenciamento de riscos das aquisições - caso C

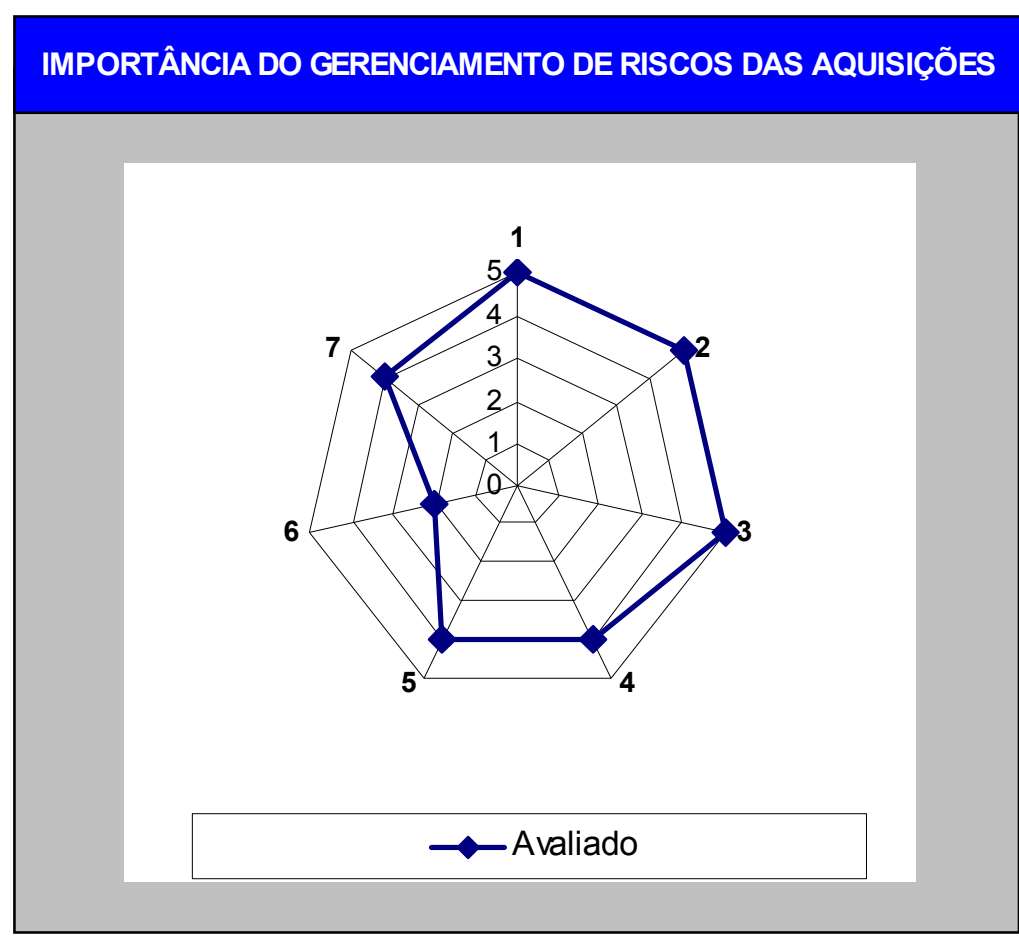

Fonte - Elaborada pelo autor

\subsubsection{Estruturação}

\subsection{Organização}

O objeto de estudo possui um escritório centralizado de gerenciamento de projetos que define os procedimentos de gerenciamento dos riscos do projeto, capacita às equipes dos projetos, atua como facilitador na aplicação de gerenciamento de riscos para os projetos e faz o acompanhamento da execução das principais ações do plano de riscos.

A área de aquisição é dividida em materiais e contratações, sendo a área de materiais centralizada para toda a empresa e área de contratações descentralizada, fazendo parte da estrutura de cada projeto estratégico da empresa. Não há um 
procedimento específico para o gerenciamento de riscos das aquisições, as categorias mais relevantes de riscos das aquisições são incorporadas no procedimento de gerenciamento de riscos dos projetos.

O escritório central de gerenciamento de projetos possui 14 colaboradores e durante a fase de definição dos projetos faz a interface entre as áreas da empresa, ou seja, as unidades de negócios, área de aquisição e equipes dos projetos.

Figura 32 - Estrutura organizacional típica - caso C

\subsection{Processos}

A empresa C desenvolve os seus projetos utilizando a metodologia do IPA (Independent Project Analysis) com pequenas adaptações para o negócio, na qual o projeto é progressivamente desenvolvido em fases de planejamento até a sua aprovação e início da execução. Todos os projetos com valores superiores a US\$10 milhões de dólares são avaliados por uma empresa independente externa. A análise de riscos coordenada pelo escritório central de projetos inicia-se na fase de FEL2 e é concluída na fase FEL3. Em ambas as fases são geradas um documento com os riscos e respostas definidos para o projeto. Devido a estrutura organizacional da empresa $C$, as estratégias de aquisições dos projetos é realizada por outras áreas, que são envolvidas na concepção da definição do projeto. Este envolvimento da 
área de aquisições é pequeno não indicando uma postura muito estratégica da área, e sim uma postura mais transacional.

Durante a fase de contratação as compras de equipamentos e materiais são executadas pela área de aquisição centralizada da empresa C e as compras de obras e serviços são executadas pela área de construção e montagem específica do projeto. Neste período a área de projetos acompanha e controla as ações do plano de respostas aos riscos, enquanto faz a atualização do registro de riscos e a área do escritório central de projetos faz o acompanhamento, através de auditorias periódicas na execução das principais ações do plano de respostas.

Figura 33 - Estrutura do gerenciamento de riscos das aquisições - caso C

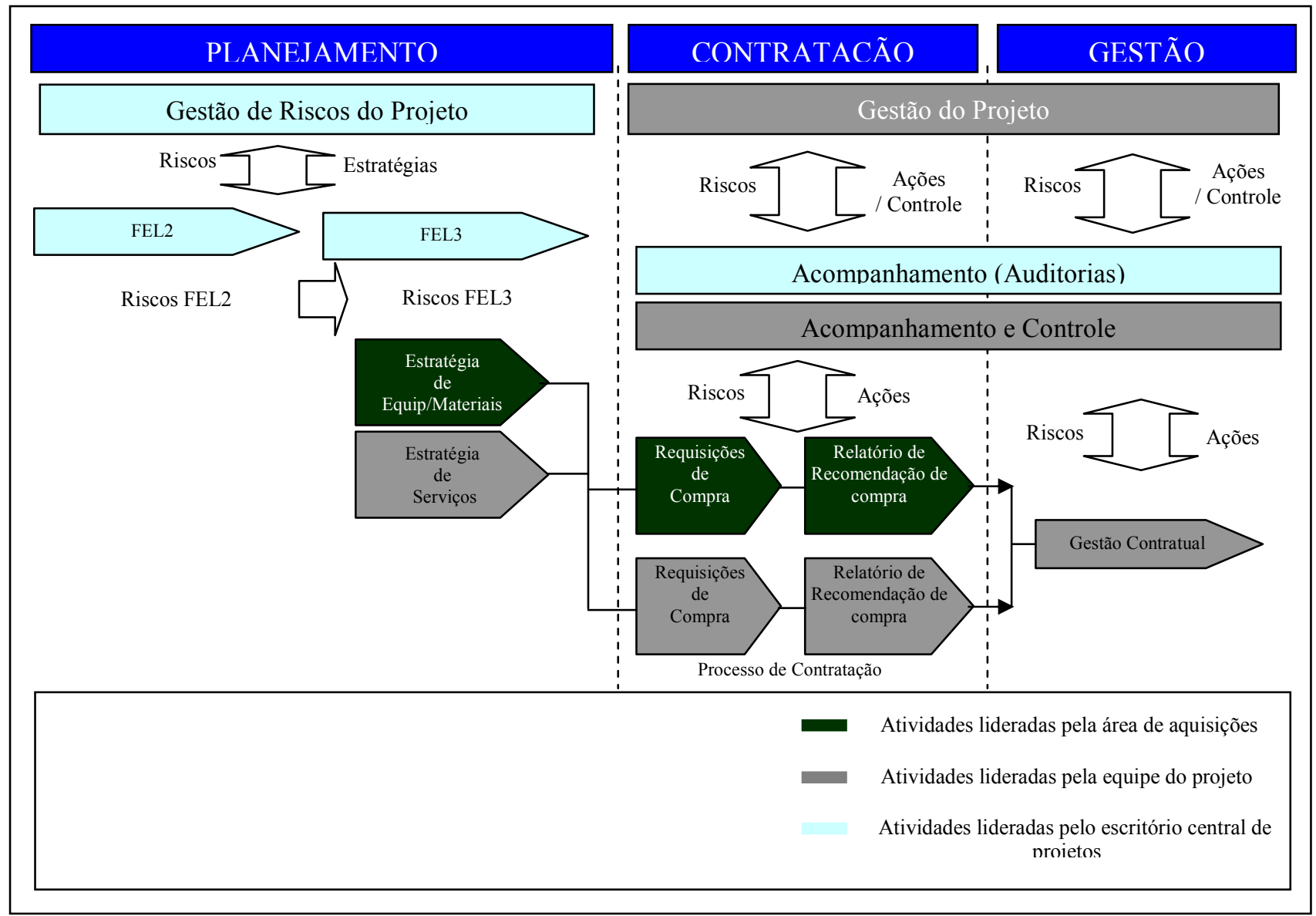

Fonte - Empresa C 
Um resumo dos resultados das entrevistas e do questionário com a identificação dos pontos fortes, em desenvolvimento e não desenvolvidos dos processos na empresa C estão indicados na tabela 19 abaixo:

Tabela 19 - Resumo dos resultados dos processos de riscos das aquisições - caso C

\begin{tabular}{|c|c|c|c|}
\hline Processos & Pontos Fortes & Pontos em desenvolvimento & Pontos näo desenvolvidos \\
\hline Planejamento de riscos & & $\begin{array}{l}\text { - Definiçẫo das categorias de riscos } \\
\text { - Treinamento de equipes envolvidas } \\
\text { - Facilitadores } \\
\text { - Envolvimento das partes interessadas } \\
\text { - Estrutura organizacional }\end{array}$ & $\begin{array}{l}\text { - Procedimento estabelecido para riscos das } \\
\text { aquisiçỗes } \\
\text { - Funçốes e responsabilidades } \\
\text { - Provisẫo de orçamento e inclusẫo no } \\
\text { cronograma do projeto } \\
\text { - Alinhamento com os objetivos do projeto }\end{array}$ \\
\hline Identificaçẫo de riscos & & $\begin{array}{l}\text { - Estrutura analítica de riscos } \\
\text { - Análise de oportunidades }\end{array}$ & $\begin{array}{l}\text { - Análise das incertezas nas premissas do } \\
\text { projeto com impacto em suprimentos } \\
\text { - Suporte para a identificaçấo dos riscos } \\
\text { - Abrangência da análise de riscos }\end{array}$ \\
\hline Análise qualitativa & - Matriz de probabilidade $x$ impacto & $\begin{array}{l}\text { - Análise da probabilidade e impactos } \\
\text { - Registro de riscos }\end{array}$ & $\begin{array}{l}\text { - Categorização de riscos com baixa } \\
\text { qualidade de informaçốes } \\
\text { - Definição de tolerância a riscos das } \\
\text { partes interessadas }\end{array}$ \\
\hline Análise quantitativa & & & - Análise quantitativa de riscos \\
\hline Plano de respostas aos riscos & - Abrangência das respostas & $\begin{array}{l}\text { - Definição dos envolvidos nas respostas } \\
\text { - Realimentação dos resultados de riscos } \\
\text { para outras áreas } \\
\text { - Utilizaçẫo de estratégias contigenciadas }\end{array}$ & $\begin{array}{l}\text { - Respostas para as oportunidades } \\
\text { - Realimentaçäo dos resultados de riscos } \\
\text { nas estratégias de aquisiçổes }\end{array}$ \\
\hline Monitoramento e controle & & $\begin{array}{l}\text { - Atualização do registro de riscos } \\
\text { - Revisốes e reavaliçốes periódicas }\end{array}$ & $\begin{array}{l}\text { - Acompanhamento da eficência das } \\
\text { respostas } \\
\text { - Controle de mudanças do projeto } \times \text { Riscos }\end{array}$ \\
\hline
\end{tabular}

Fonte - Elaborada pelo autor

A tabela 19 mostra que a empresa $C$ não possui um procedimento específico para o gerenciamento de riscos das aquisições e tem muito pontos a serem desenvolvidos neste sentido.

De qualquer maneira durante a entrevista, ficou claro que a empresa $C$ possui procedimentos bem detalhados para o gerenciamento dos projetos e tenha projetos muito bem avaliados pelas empresas de consultoria independentes.

\subsubsection{Estrutura analítica de riscos típica}

A empresa C não possui uma estrutura analítica de riscos específica para as aquisições. A estrutura analítica de riscos mostrada na tabela 20 abaixo é um resumo dos itens da estrutura analítica de riscos do projeto, referentes a aquisições de equipamentos e materiais e contratações de obras e serviços. 
Tabela 20 - Estrutura analítica de riscos de aquisições - caso C

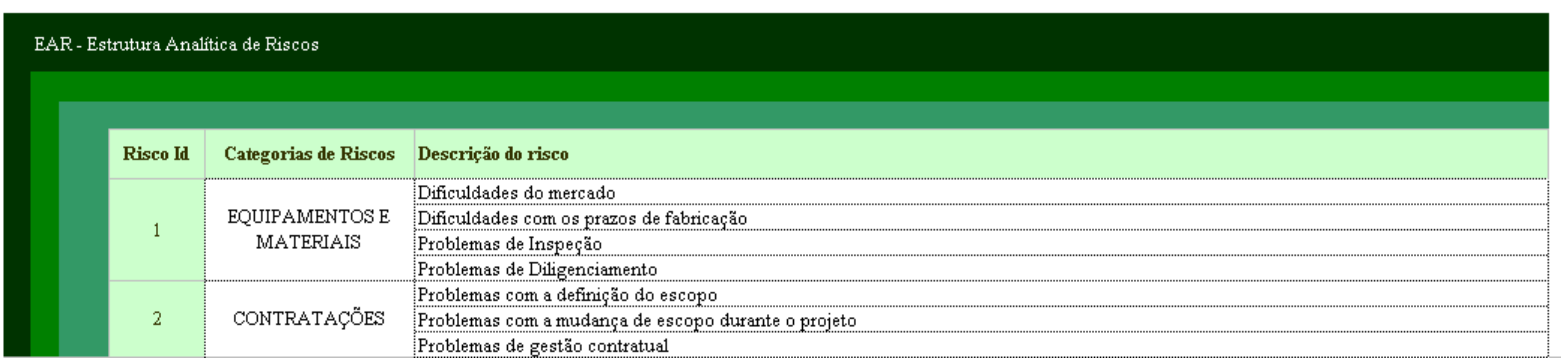

Fonte - Adaptada da Empresa C

\subsubsection{Categorias de riscos mais relevantes}

Dos itens mencionados durante a entrevista como mais relevantes de riscos para as aquisições, temos:

- Atrasos nos pareceres técnicos;

- Atrasos nas aprovações das contratações nas Diretorias;

- Atrasos na emissão da ordem de serviço, após o processo de contratação; devido a questionamento de empresas sobre o processo;

- Mudanças de escopo, durante o processo de contratação;

- Mudanças de escopo, durante a gestão contratual.

\subsubsection{Lições aprendidas}

Segundo a empresa $\mathrm{C}$ o processo de gerenciamento de riscos operacionais para os projetos está estruturado de forma mais organizada há 3 anos. Segundo os entrevistados, depois da criação da estrutura analítica de riscos dos projetos, houve uma melhoria significativa na identificação de riscos dos projetos, sendo que consideram que hoje ela atingiu um nível ótimo com pouquíssimas alterações na identificação dos riscos. Estão trabalhando na inclusão de respostas típicas na estrutura analítica de riscos, para melhorar o descritivo e nível das respostas que não tem sido de forma geral adequado. Consideram também que devido ao porte, dimensão geográfica e diversidade cultural da empresa, tem encontrado muita dificuldade no acompanhamento e controle do processo de gerenciamento de riscos 
dos projetos. Para mitigar estas dificuldades estão trabalhando na capacitação das equipes em gerenciamento de projetos, antecipando a definição e envolvimento do gerente de projetos das unidades de negócios para a fase de FEL2 e procurando envolver de forma mais ativa a área de aquisições da empresa.

Encontraram muita dificuldade na aplicação e acompanhamento do gerenciamento de riscos, sem a utilização de um sistema. Atualmente estão trabalhando no desenvolvimento de um sistema para dar o suporte no gerenciamento de riscos.

\subsubsection{Práticas complementares}

Como a empresa C utiliza bastante a modalidade de contratação EPC, a qual requer um nível de definição de engenharia bem avançado, utiliza para os projetos a serem contratados em EPC o detalhamento de engenharia e as técnicas do FEED, garantindo assim uma especificação mais adequada para as licitações.

Para acompanhamento das principais respostas dos planos de riscos dos projetos, a empresa $\mathrm{C}$ utiliza um indicador de desempenho de riscos (IDR) o qual monitora se as principais ações estão sendo executadas dentro do prazo previsto. Segundo a empresa C esta iniciativa tem motivado os gerentes de projetos, devido a competição na obtenção da melhor nota neste indicador.

A empresa C utiliza também um relatório de acompanhamento de projetos que circula nos níveis executivos da empresa com um capítulo especial de riscos, o qual indica o nível de riscos de cada projeto e o indicar IDR. 


\section{ANÁLISE CRÍTICA}

Para melhor interpretação e análise crítica dos dados, são detalhados abaixo os resultados dos casos estudados, fazendo comparações entre eles com o objetivo de responder as perguntas chave objeto deste estudo.

\subsection{Importância do Gerenciamento de Riscos das Aquisições}

A tabela 21 abaixo mostra a consolidação dos resultados dos estudos de casos com relação ao contexto e a importância do gerenciamento de riscos das aquisições.

Tabela 21 - Importância do Gerenciamento de Riscos

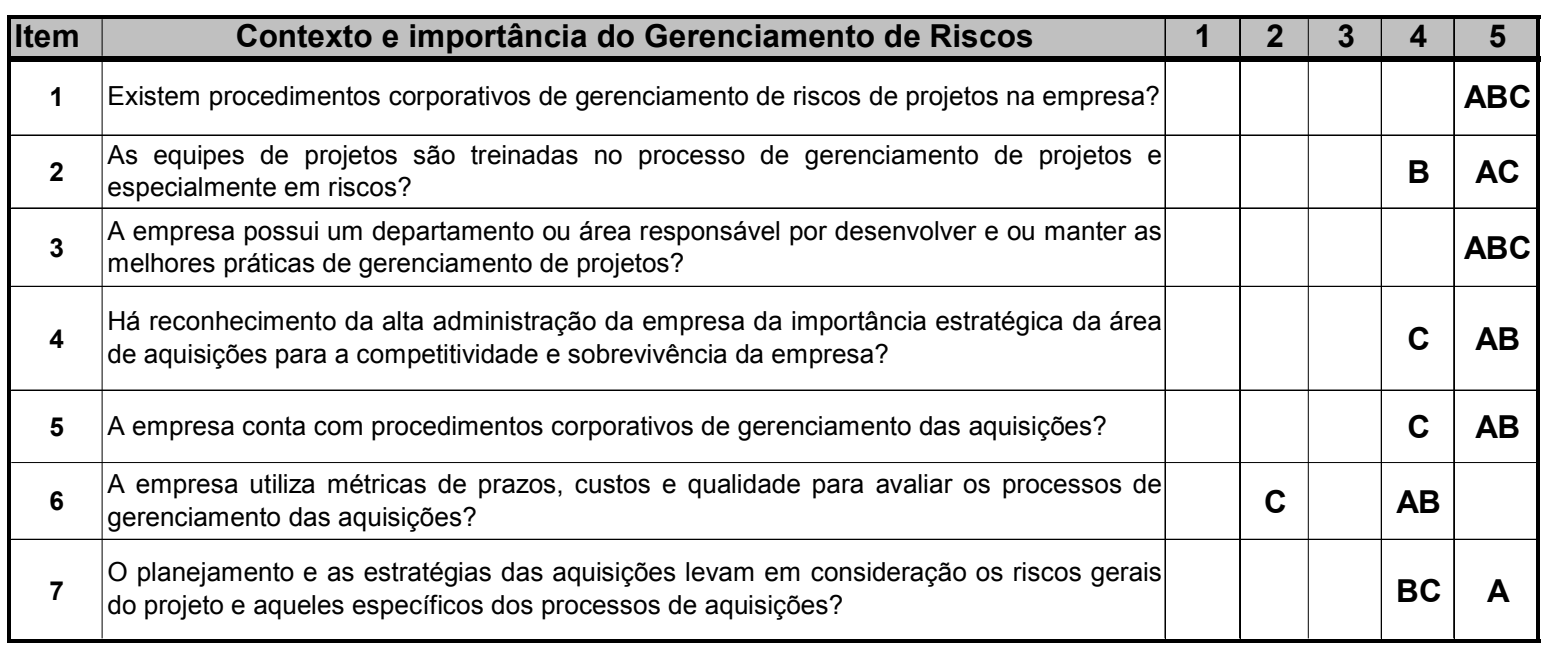

\section{Legenda:}

1 Discordo Totalmente
2 Discordo
3 Neutro
4 Concordo
5 Concordo Totalmente
A = Estudo de Caso A
$B=$ Estudo de Caso B
$C=$ Estudo de Caso C

Fonte - Adaptada dos casos A, B e C

Verifica-se que todas as empresas pesquisadas possuem um procedimento corporativo de gerenciamento de riscos de projetos, sendo que as empresas $A$ e $B$ já possuem um procedimento específico para os riscos envolvidos nas aquisições, todas elas capacitam os envolvidos no processo de riscos, centralizam as melhores práticas de gerenciamento de projetos em um escritório de projetos, possuem 
procedimentos corporativos para as aquisições sendo que as empresas $A$ e $B$ utilizam-se fortemente de métricas para medir o desempenho das aquisições, e todas utilizam parte dos resultados de riscos para revisão das estratégias das aquisições. Além disso as empresas reconhecem a importância estratégica da área de aquisições. Este posicionamento afirmativo das empresas pesquisadas somados a forma como estão estruturadas indicam uma valorização do gerenciamento de riscos para as aquisições.

\subsection{Estruturação, Aderência e Consolidação das Práticas}

Nas figuras 34, 35 e 36 os resultados dos processos do gerenciamento de riscos dos casos estudados estão sumarizados segundo o PMBOK (2004) e indicam o resultado encontrado de cada caso. $O$ instrumento de pesquisa utiliza para cada processo uma série de perguntas, conforme apêndice $A$, utilizando a escala likert de 1 a 5 . Os resultados da pontuação mostrados para cada processo são uma média simples das pontuações.

\section{Caso A:}

Figura 34 - Resultado do caso A

\begin{tabular}{|c|l|c|}
\hline \multicolumn{2}{|c|}{ ITENS } & Pontuação \\
\hline 1 & Planejamento & 4,0 \\
\cline { 2 - 3 } 2 & Identificação & 3,5 \\
\cline { 2 - 3 } 3 & Qualitativo & 4,2 \\
\cline { 2 - 3 } 4 & Quantitativo & 1,0 \\
\cline { 2 - 3 } 5 & Respostas & 3,5 \\
\cline { 2 - 3 } 6 & Monitoramento e Controle & 4,3 \\
\hline \multicolumn{2}{|c|}{ Somatório: } & 20,5 \\
\hline
\end{tabular}

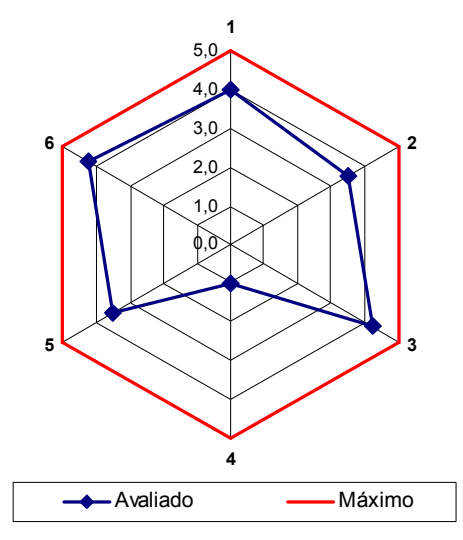

Fonte - Elaborada pelo autor

O caso internacional A que utiliza uma estrutura organizacional de aquisições descentralizada e dedicada ao projeto, apresenta a melhor pontuação dos casos estudados, entretanto não utiliza a análise quantitativa dos riscos das aquisições. A pontuação obtida representa $68,3 \%$ da pontuação máxima. 


\section{Caso B:}

Figura 35 - Resultado do caso B

\begin{tabular}{|c|l|c|}
\hline \multicolumn{2}{|c|}{ ITENS } & Pontuação \\
\hline 1 & Planejamento & 3,8 \\
\cline { 2 - 3 } 2 & Identificação & 3,3 \\
\cline { 2 - 3 } 3 & Qualitativo & 2,6 \\
\cline { 2 - 3 } 4 & Quantitativo & 2,7 \\
\cline { 2 - 3 } 5 & Respostas & 2,5 \\
\cline { 2 - 3 } 6 & Monitoramento e Controle & 1,8 \\
\hline \multicolumn{2}{|c|}{ Somatório: } & 16,5 \\
\hline
\end{tabular}

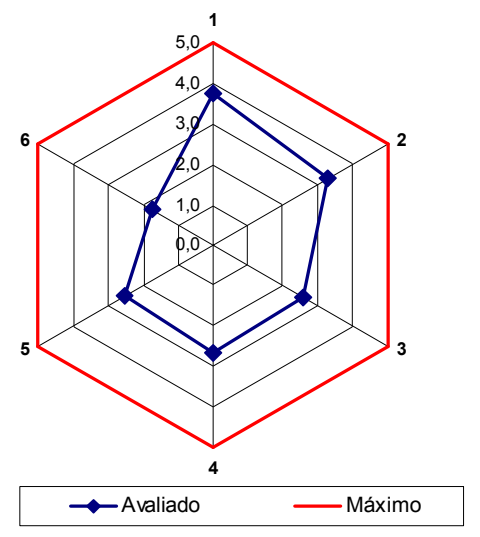

Fonte - Elaborada pelo autor

O caso B que utiliza uma estrutura organizacional de aquisições centralizada apresenta uma pontuação intermediária entre os casos estudados, com destaque por ser o único dos casos que utiliza a análise quantitativa para o gerenciamento dos riscos das aquisições e também por sua baixa aderência no monitoramento e controle dos riscos. A pontuação obtida representa $55,0 \%$ da pontuação máxima.

\section{Caso C:}

Figura 36 - Resultado do caso C

\begin{tabular}{|l|l|c|}
\hline \multicolumn{2}{|c|}{ ITENS } & Pontuação \\
\hline 1 & Planejamento & 1,5 \\
\cline { 2 - 3 } 2 & Identificação & 2,3 \\
\cline { 2 - 3 } 3 & Qualitativo & 3,4 \\
\cline { 2 - 3 } 4 & Quantitativo & 1,8 \\
\cline { 2 - 3 } 5 & Respostas & 3,5 \\
\cline { 2 - 3 } 6 & Monitoramento e Controle & 2,0 \\
\hline \multicolumn{2}{|c|}{ Somatório: } & 14,5 \\
\hline
\end{tabular}

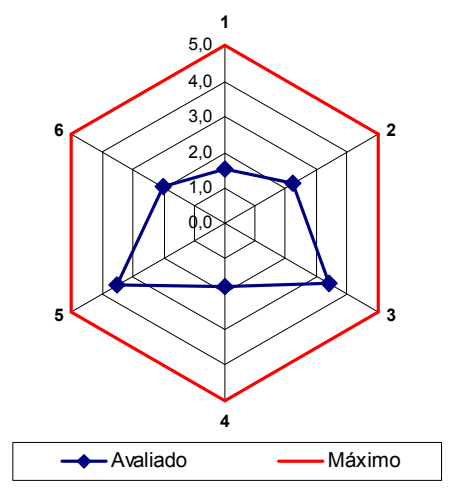

Fonte - Elaborada pelo autor 
O caso $C$ que utiliza uma estrutura organizacional de aquisições mista (centralizada para equipamentos e materiais e descentralizada para obras e serviços), apresenta a menor pontuação dos casos estudados. Embora existam procedimentos corporativos para o gerenciamento de riscos dos projetos, não há um procedimento específico de gerenciamento de riscos para as aquisições. Destaca também a não utilização de métodos quantitativos $e$ as dificuldades mencionadas com 0 monitoramento e controle dos riscos. A pontuação obtida representa $48,3 \%$ da pontuação máxima.

A figura 37 mostra o resultado consolidado dos três casos estudados, extraído através da média simples da pontuação final obtida de cada caso.

Figura 37 - Resultado consolidado dos casos

\begin{tabular}{|l|l|c|}
\hline \multicolumn{2}{|c|}{ ITENS } & Pontuação \\
\hline 1 & Planejamento & 3,1 \\
\cline { 2 - 3 } 2 & Identificação & 3,0 \\
\cline { 2 - 3 } 3 & Qualitativo & 3,4 \\
\cline { 2 - 3 } 4 & Quantitativo & 1,8 \\
\cline { 2 - 3 } 5 & Respostas & 3,2 \\
\cline { 2 - 3 } 6 & Monitoramento e Controle & 2,7 \\
\hline \multicolumn{2}{|c|}{ Somatório: } & 17,2 \\
\hline
\end{tabular}

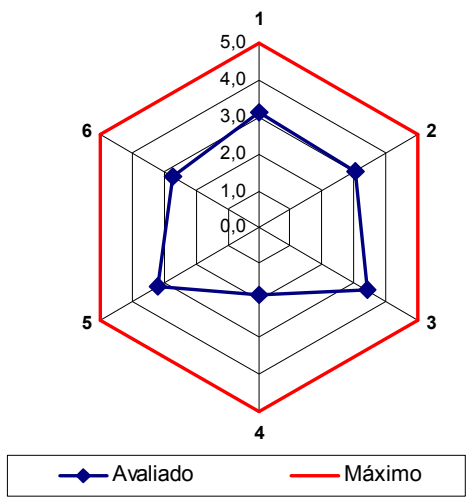

Fonte - Elaborada pelo autor

De forma geral a aderência das práticas dos casos estudados comparados a teoria é limitida, chamando a atenção a baixa pontuação dos processos de análise quantitativa dos riscos e monitoramento e controle. A pontuação média obtida representa $57,3 \%$ da pontuação máxima.

Na tabela 22 os processos de gerenciamento de riscos são detalhados e os estudos de casos são posicionados em três níveis (pontos fortes, pontos em desenvolvimento e pontos não desenvolvidos) de acordo com a qualificação de cada caso $A, B$ e $C$ obtida nos instrumentos de pesquisa, sendo nota 5 considerada ponto forte, notas 4 ou 3 pontos em desenvolvimento e notas 2 ou 1 como ponto não 
desenvolvido. A análise crítica da aderência da teoria à prática e identificação da consolidação das práticas foi realizada considerando-se o posicionamento dos casos estudados. Para identificação de práticas consolidadas e não consolidadas no gerenciamento de riscos para as aquisições, considerou-se como indícios de práticas consolidadas aquelas com posicionamento de no mínimo 2 casos como pontos fortes e nenhum caso como ponto não desenvolvido. Já para identificação de práticas ainda não consolidadas considerou-se aquelas com no mínimo 2 casos como pontos não desenvolvidos e nenhum caso como ponto forte.

Tabela 22 - Detalhamento dos processos dos casos estudados

\begin{tabular}{|c|c|c|c|c|}
\hline Processos & Referência Teórica & Pontos Fortes & $\begin{array}{c}\text { Pontos em } \\
\text { desenvolvimento }\end{array}$ & $\begin{array}{c}\text { Pontos näo } \\
\text { desenvolvidos }\end{array}$ \\
\hline \multirow{9}{*}{ Planejamento de riscos } & Procedimento estabelecido para riscos das aquisiçốes & A B & & $\mathrm{C}$ \\
\hline & Funçốes e responsabilidades & & A B & $\mathrm{C}$ \\
\hline & Provisẫo de orçamento e inclusẫo no cronograma do projeto & & A B & $\mathrm{C}$ \\
\hline & Definiçẫo das categorias de riscos & & A B C & \\
\hline & Alinhamento com os objetivos do projeto & & A B & $\mathrm{C}$ \\
\hline & Envolvimento das partes interessadas & A & B C & \\
\hline & Treinamento de equipes envolvidas & $\mathrm{A}$ & B C & \\
\hline & Facilitadores & A B & C & \\
\hline & Estrutura organizacional & A & C & B \\
\hline \multirow{5}{*}{ Identificaçẫo de riscos } & Abrangência da análise de riscos & A B & & C \\
\hline & $\begin{array}{l}\text { Análise das incertezas nas premissas do projeto com impacto } \\
\text { em suprimentos }\end{array}$ & & A B & C \\
\hline & Suporte para a identificaçẫo dos riscos & & A B & $\mathrm{C}$ \\
\hline & Análise de oportunidades & & $\mathrm{C}$ & A B \\
\hline & Estrutura analitica de riscos & & A B C & \\
\hline \multirow{5}{*}{ Análise qualitativa } & Matriz de probabilidade $x$ impacto & $\mathrm{A} C \mathrm{C}$ & B & \\
\hline & Definiçẫo de tolerância a riscos das partes interessadas & & A & B C \\
\hline & Análise da probabilidade e impactos & A & B C & \\
\hline & Registro de riscos & A & B C & \\
\hline & Categorizaçẫo de riscos com baixa qualidade de informaçốes & & & A B C \\
\hline \multirow{5}{*}{ Análise quantitativa } & Análise quantitativa de riscos & B & & $\mathrm{A} C$ \\
\hline & Suporte de especialistas & & $\mathbf{B}$ & $\mathrm{AC}$ \\
\hline & Uso de ferramentas e técnicas de análise quantitativa & & B & A C \\
\hline & Simulação para atender limites das partes interessadas & & B & A C \\
\hline & Impacto das incertezas nos objetivos do projeto & & B & $\mathrm{A} C$ \\
\hline \multirow{6}{*}{ Plano de respostas aos riscos } & Definiçẫo dos envolvidos nas respostas & & A B & \\
\hline & Abrangência das respostas & $\mathrm{A} C$ & & B \\
\hline & Respostas para as oportunidades & & & A B C \\
\hline & Utilizaçẫo de estratégias contigenciadas & & $\mathrm{A} C$ & B \\
\hline & $\begin{array}{l}\text { Realimentaçẫo dos resultados de riscos nas estratégias de } \\
\text { aquisiçốes }\end{array}$ & & A B & C \\
\hline & Realimentação dos resultados de riscos para outras áreas & & A B C & \\
\hline \multirow{4}{*}{ Monitoramento e controle } & Revisốes e reavaliçỗes periódicas & A & $\mathrm{C}$ & B \\
\hline & Acompanhamento da eficência das respostas & & A & B C \\
\hline & \begin{tabular}{|c|} 
Controle de mudanças do projeto $\times$ Riscos \\
\end{tabular} & & A & B C \\
\hline & Atualização do registro de riscos & A & C & B \\
\hline
\end{tabular}

\section{Legenda:}

$A=$ Estudo de Caso A
$B=$ Estudo de Caso B
$C=$ Estudo de Caso C

Fonte - Adaptada dos casos A, B e C 
A avaliação da tabela 22 acima, comparando-se o posicionamento de cada empresa na avaliação dos estudos de casos, sugere as seguintes observações, :

Com relação ao planejamento de riscos das aquisições, de forma geral vê-se uma concentração do posicionamento dos casos estudados como pontos em desenvolvimento. Isto de certa forma pode indicar uma preocupação e esforços das empresas avaliadas no sentido de desenvolver e aprimorar especificamente seus procedimentos de gerenciamento de riscos das aquisições, melhorarem a definição das suas categorias de riscos, envolver de forma mais adequada às partes interessadas e capacitar as equipes envolvidas. Verifica-se que das práticas de planejamento a utilização de facilitadores no processo de gerenciamento de riscos parece estar consolidada.

$\mathrm{Na}$ identificação de riscos, verifica-se se excluindo a empresa $\mathrm{C}$ que não possui um procedimento específico de gerenciamento de riscos para aquisições, um bom nível de desenvolvimento dos processos no que se refere aos riscos com impactos negativos nos projetos e uma não aderência na não utilização de forma adequada da identificação de oportunidades, indicando ser uma prática não consolidada ainda nas empresas.

Com relação à análise qualitativa de riscos, observa-se de forma geral uma matriz e processo de análise de probabilidade e impacto e registro de riscos bem definidos, sendo a matriz qualitativa de probabilidade e impacto de riscos uma prática aparentemente consolidada e práticas não consolidadas de definição da tolerância a riscos das partes interessadas e categorização de riscos com baixa qualidade de informações.

$\mathrm{Na}$ análise quantitativa de riscos executada apenas pela empresa $\mathrm{B}$, verifica-se de forma geral a menor aderência nos processos de gerenciamento de riscos analisados. Verificou-se que na empresa B a gestão de riscos das aquisições é parte integrante do processo de gestão de riscos dos projetos, o qual também utiliza uma análise quantitativa dos riscos, sendo uma exigência para aprovação dos projetos de grande porte da empresa. Porém mesmo na empresa B este processo foi implementado recentemente e ainda passa por uma fase de adaptações. De forma 
geral a análise quantitativa parece não ser uma prática ainda consolidada nas empresas.

No plano de respostas aos riscos, observa-se de forma geral um bom nível de desenvolvimento dos processos, entretanto sendo a principal não aderência na elaboração das respostas para as oportunidades indicando não ser ainda uma prática consolidada nas empresas.

O monitoramento e controle de forma geral mostram-se mais desenvolvidos na empresa $A$ e não aderentes na maioria dos casos no que diz respeito ao acompanhamento da eficiência das respostas e impactos das mudanças do projeto nos riscos das aquisições indicando também não ser ainda práticas consolidadas nas empresas.

\subsection{Categorias de Riscos}

Para a análise crítica da estrutura analítica de riscos e as categorias mais relevantes de riscos das aquisições considerou-se como base a estrutura do caso $A$, com a subdivisão em contratos (obras e serviços) e suprimentos (equipamentos e materiais), acrescentando-se quando necessário outras categorias e riscos dos outros estudos de casos.

As tabelas 23 e 24 mostram os resultados consolidados dos casos. Para melhor análise utilizou-se o sistema de cores para identificar a fonte de origem das informações, sendo a fonte de origem indicada através das seguintes cores (caso $A$ - preto, caso B - azul e caso C - vermelho) e a marcação de um X para as categorias e riscos considerados mais relevantes para cada caso no intuito de identificar aquelas categorias e riscos com maiores indicações. 
Tabela 23 - Estrutura Analítica de Riscos de Contratos

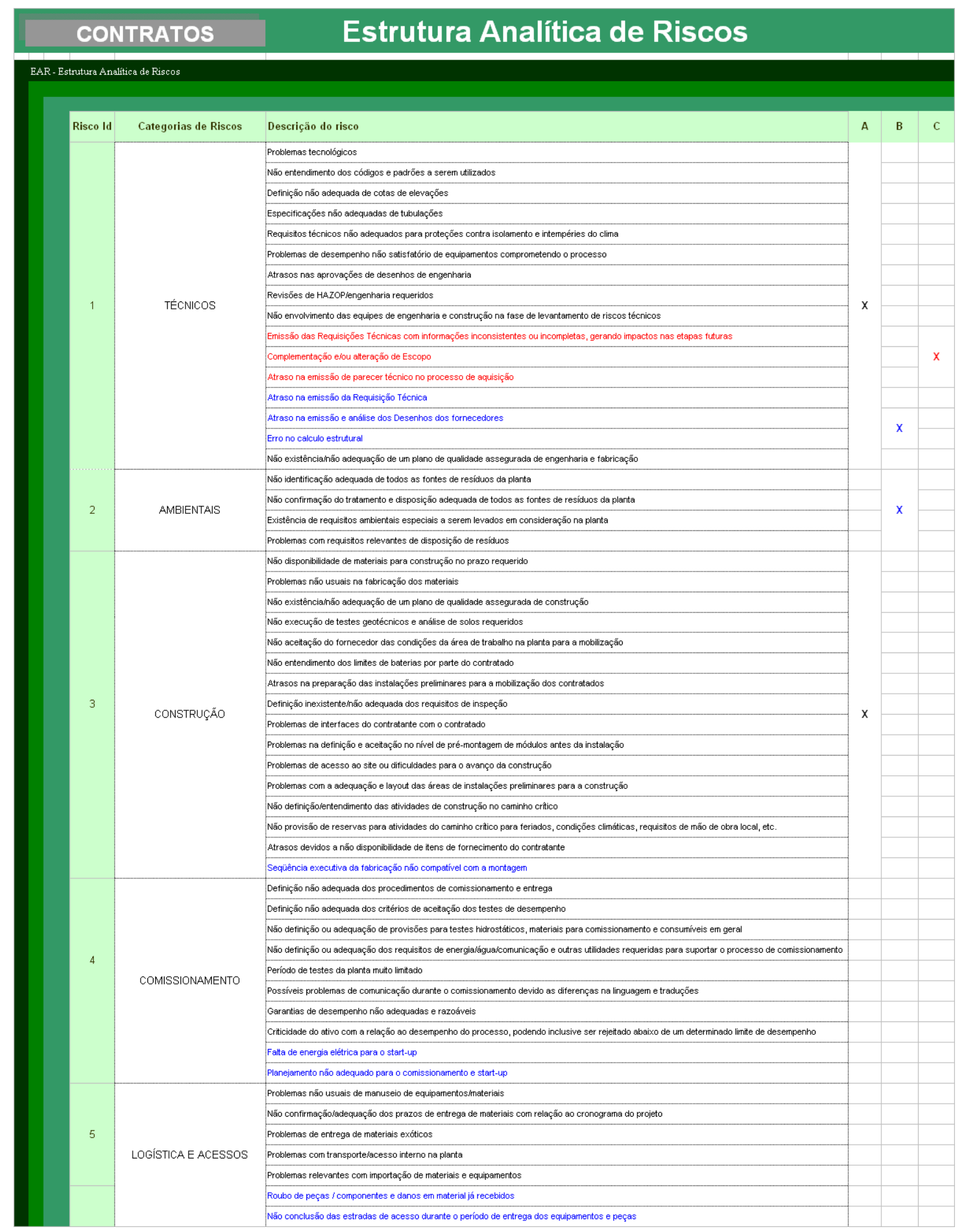




\begin{tabular}{|c|c|c|c|c|c|}
\hline \multicolumn{6}{|c|}{ EAR - Estrutura Analitica de Riscos } \\
\hline Risco Id & Categorias de Riscos & Descriçäo do risco & A & B & $c$ \\
\hline \multirow{9}{*}{6} & \multirow{3}{*}{ PAís } & Problemas com autorizaç̋es gerais requeridas pelo pais que afetem o projeto & \multirow{3}{*}{$\mathrm{x}$} & & \\
\hline & & Dependência da disponiblilidade / adequaç̧ăo de må̃o de obra local para execuuçăo dos trabalhos & & & \\
\hline & & Exigência de requisttos especiais de adequaçấo com códigosnleis locais & & & \\
\hline & \multirow{6}{*}{ COMERCIAL } & Responsabilidades de seguros em desacordo com os padrốes da empresa & & & \\
\hline & & Nấo utilizaçẩo adequada das gararntias bancárias e retenç̧̋́es de pagamentos & & & \\
\hline & & Năo suporte financeiroigarantia da empresa principal do grupo & & & \\
\hline & & Mercado no linite da capacidade tisica de fornecimento & & \multirow[t]{2}{*}{$\mathrm{x}$} & \\
\hline & & Maior prazo de eniissăo do parecer técnico em funçấo do número de propostas. & & & \\
\hline & & Pacote com alçada máxima de aprovaçäo gerando atrasos nas aprovaçöes & & & \multirow{33}{*}{$x$} \\
\hline \multirow{32}{*}{8} & \multirow{32}{*}{ CONTRATUAL } & Näo definiçẫo clara/adequada do escopo de trabalho dentro do contrato & & & \\
\hline & & Ordem de precedência dos documentos dentro do contrato năo previlegiando o escopo do projeto & & & \\
\hline & & Fatta de experiência de ter trabalhado anteriormente com o fornecedor & & & \\
\hline & & Não entendimentoliacettaçáo do tornecedor da condiç̧és e procedimertos de trabalho na planta & & & \\
\hline & & Definiç̧âo nâo adequada de preços do fornecedor para emprettada global das entregas bern definidas de trabalhos requeridas & & & \\
\hline & & Atrasos ou problemas com aprovaç̧̋es de sub-tornecedores para materiaisiequiparnentos e serviços & & & \\
\hline & & Nấo adequaçâolapresentaçẩo do plano de trabalho de sub-fornecedores & & & \\
\hline & & Fatta de experiência de ter trabalhado anteriormente com o sub-fornecedor & & & \\
\hline & & Marcos contratuais nâo bem definidos e nâao realisticos & & & \\
\hline & & Utilizaçâo de sub-fornecedores cujos mercados nấo săo compettivos & & & \\
\hline & & Fatta de capacidadeldisponibilidade do mercado local para atender as demandas do contrato & & & \\
\hline & & Năo definiç̧ấolacordo com relaçăo a emissẩo da lista de materiais para a obra & & & \\
\hline & & Năo definiç̧ôo de preços e quartidades para todos os materiais e serviços requeridos nos contratos de "schedule of rates" & & & \\
\hline & & Fatta de preços fixos e firmes para mais do $80 \%$ do material direto envolvido no contrato & & & \\
\hline & & Definiçăo nắo adequada/clara de responsabilidades por atrasos & & & \\
\hline & & Definiçăon nắo adequada do perído de gararntia e aceitlaçăo final & & & \\
\hline & & Problemas com falhas nas garantias de desempenho & & & \\
\hline & & Possibilidade de plettos e adtivos acima da média & & & \\
\hline & & Pagamentos de fornecedores nấo alinhados com progresso fisicco e desempenho & & & \\
\hline & & Nâo utilizaçẫo de gararntias contratuais de cumprimento de prazos & & & \\
\hline & & Mudanças de escopo durante a execuçäo do contrato & & & \\
\hline & & Atraso na mobilizaçấo da equipe do contratante & & & \\
\hline & & Atraso na mobilizaçẫo da equipe da Gerenciadora & & $\mathrm{x}$ & \\
\hline & & Atraso na mobilizaçăo da equipe da contratada devido a fatta de mäo de obra local & & & \\
\hline & & Atraso na emissä́o da Ordem de Serviço & & & \\
\hline & & Desentendimento entres as empresas que formam o consórcio e matriz de responsabilidade nâo definida & & & \\
\hline & & Necessidade de autorizaçä̌o para subfornecedores & & & \\
\hline & & Má gestấo dos sub-tornecedores & & & \\
\hline & & Impossibilidade de início dos serviços devido a pendências de outros contratos antecessores. & & & \\
\hline & & Retrabalho devido ao atendimento inadequado dos fornecedores locais & & & \\
\hline & & Năo reconhecimento de méritos de adtivos e plettos gerando paralisaçăo e ejou abandono da obra & & & \\
\hline & & Reprogramaçâao da execuçẫo dos serviços em funçâo da autorizaçâo de expansâo futura & & & \\
\hline \multirow[t]{2}{*}{9} & \multirow{2}{*}{$\begin{array}{l}\text { SAÚDE E SEGURANÇA } \\
\text { OCUPACIONAL }\end{array}$} & Ataque de aninais silvestres na equipe mobilizada. & & \multirow{2}{*}{$\mathrm{x}$} & \\
\hline & & Ocorrência de epidenia na equipe mobilizada & & & \\
\hline 10 & CONDIÇÓES CLIMÁTICAS & Baixa produtividade devido a chuvas & & & \\
\hline 11 & COMUNIDADADE LOCAL & IIterrupçấo dos serviços pela comuniidade local & & & \\
\hline 12 & $\begin{array}{l}\text { VANDALISMO, GREVE, VIOLÊNCIA } \\
\text { LOCAL }\end{array}$ & Vandalismo, greve, violência local & & & \\
\hline
\end{tabular}

Fonte - Adaptada dos casos A, B e C 
Tabela 24 - Estrutura Analítica de Riscos de Suprimentos

\begin{tabular}{|c|c|c|c|c|c|}
\hline \multicolumn{2}{|c|}{ SUPRIMENTOS } & \multicolumn{4}{|l|}{ Estrutura Analfica de Riscos } \\
\hline \multicolumn{6}{|c|}{ EAR - Estrutura Analitica de Riscos } \\
\hline Risco Id & Categorias de Riscos & Descriçäo do risco & A & B & c \\
\hline \multirow{14}{*}{1} & \multirow{14}{*}{ TÉCNICOS } & Problemas tecnológicos & & & \\
\hline & & Näo entendimento dos códigos e padröes a serem utilizados & & & \\
\hline & & Utilizaçăo de materiais exóticos ou de longo prazo de entrega & & & \\
\hline & & Problemas de desempenho nåoo satisfatório de equipamentos podendo comprometer o processo & & & \\
\hline & & Revisöes de HAZOPiengenharia requeridos & & & \\
\hline & & Atrasos devido a necessidade de aprovaçöes de desenhos relevartes de engenharia & & & \\
\hline & & Nắo existênciainăo adequaçắo de um plano de qualidade assegurada de engenharia e tabricaçắo & & & \\
\hline & & Atraso na emissǻo e análise dos Desenhos dos fornecedores & & & \\
\hline & & Desenhos dos fornecedores incompativeis com o projeto básico & & \multirow{2}{*}{$\mathrm{x}$} & \multirow{6}{*}{$\mathrm{x}$} \\
\hline & & Erro no calculo estrutural & & & \\
\hline & & Maior prazo de enissäo do parecer técnico en funç̧ăo do número de propostas. & & & \\
\hline & & Enissấo das Requisiçóes Técnicas com informąçóes inconsistentes ou incompletas, gerando inpactos nas etapas futuras & & & \\
\hline & & Complementaçą̧ăo elou alteraçăo de Escopo & & & \\
\hline & & Atraso na eniissấo da Requisiçắo Técnica & & & \\
\hline \multirow{10}{*}{2} & \multirow{10}{*}{ FABRICAÇÃO / INSTALAÇÄO } & Problemas com manuseio de materiaisifecuipanerntos perigosos ou que requerem cuidados espećificos de manuseio & & & \\
\hline & & Fabricaçăooinstalaçăo de equipanentos com tecnologia ainda năo provada ou com atto grau de complexidade & & & \\
\hline & & Nấo existênciainâa adequaçấo de un plano de qualidade assegurada de tabricaçẫo e testes & & & \\
\hline & & Definiç̧ăo inexistenteinåao adequada dos requistos de inspeçăo & & & \\
\hline & & Atrasos devido a problemas de interfaces de fornecinento e fabricaçăo ou interferênncias externas & & & \\
\hline & & Problemas na definiçăoo e aceitaçẩo no nivel de pré-montagen de módulos artes da instalaçấo & & & \\
\hline & & Năo definiçăojerentendimento das stividades de canninho crtico do projeto & & & \\
\hline & & Nắo provisấo de reservas para atividades do caninho crtico para feriados, condiçóes climáticas, requistos de mấo de obra local, etc. & & & \\
\hline & & Seqüência executiva da fabricaçăo nẩo compativel com a montagem & & & \\
\hline & & Planejamento e logisticas de inspeçăo deficiertes & & & \\
\hline \multirow{11}{*}{3} & \multirow{11}{*}{ COMISSIONAMENTO } & Definiç̧âa náa adequada dos requistos de necessidade de acompanhamento da montagem/conissionamento por especialistas & & & \\
\hline & & Definiçấo nâo adequada dos procedinentos de conissionamento e entrega & & & \\
\hline & & Definiçâa nấo adequada dos crttérios de aceitaçấo dos testes de desempenho & & & \\
\hline & & Năo definiçăoo ou adequaçăo de provisōes para testes hidrostáticos, materiais para comissionamento e consuniviveis em geral & & & \\
\hline & & Nắo definiçăo ou adequaçắo dos requistos de energialágualicomunicaçăa e outras utilidades requeridas para suportar o processo de comissionamento & & & \\
\hline & & Período de testes da planta muto linitado & & & \\
\hline & & Possiveis problemas de comunicaçăo durante o conissionamento devido as diferennças na linguagemen etraduç̧öes & & & \\
\hline & & Garantias de desenpenho năo adequadas e razoáveis & & & \\
\hline & & Crrticidade do ativo com a relaçăo ao desempenho do processo, podendo inclusive ser rejeittado abaixo de um deterninado linite de desempenho & & & \\
\hline & & Fatta de energia elétrica para o start-up & & & \\
\hline & & Planejamento para o comissionananento e start-up & & & \\
\hline \multirow{9}{*}{4} & \multirow{9}{*}{ LOGISTICA E ACESSOS } & Problemas näo usuais de manuseio de equipanentosinnateriais & \multirow{9}{*}{$\mathrm{x}$} & & \\
\hline & & Năo confirmaçắoladequaçấo dos prazos de entrega de materiais com relaçăoo ao cronograma do projeto & & & \\
\hline & & Problemas de entrega de materiais exóticos & & & \\
\hline & & Problemas com transportelacesso interno na planta & & & \\
\hline & & Problemas relevartes com inportaçăo de materiais e equipannentos & & & \\
\hline & & Danificaçầo / perda das peças e componentes & & & \\
\hline & & Dificuldade no rastreamento e localizaçăo das peças e componentes & & & \\
\hline & & Fatta de otimizaçăo de logisstica & & & \\
\hline & & Roubo de peças / componentes e danos em material já recebidos & & & \\
\hline \multirow{4}{*}{5} & \multirow{4}{*}{ PAIS } & Problemas com autorizaçōes de inportaçăo os quais podem afetar o processo de inportaçăo e liberaçăo na alfândega & & & \\
\hline & & Problemas com vistos para a mấo de obra associada aos trabalhos no país & & & \\
\hline & & Exigência de licenças, aprovaçées governamentais ou autorizaçêes especiais para equipanentos & & & \\
\hline & & Exigência de requistos especiais de adequaçấo com códigosłleis locais & & & \\
\hline
\end{tabular}




\section{SUPRIMENTOS}

\section{Estrutura Analítica de Riscos}

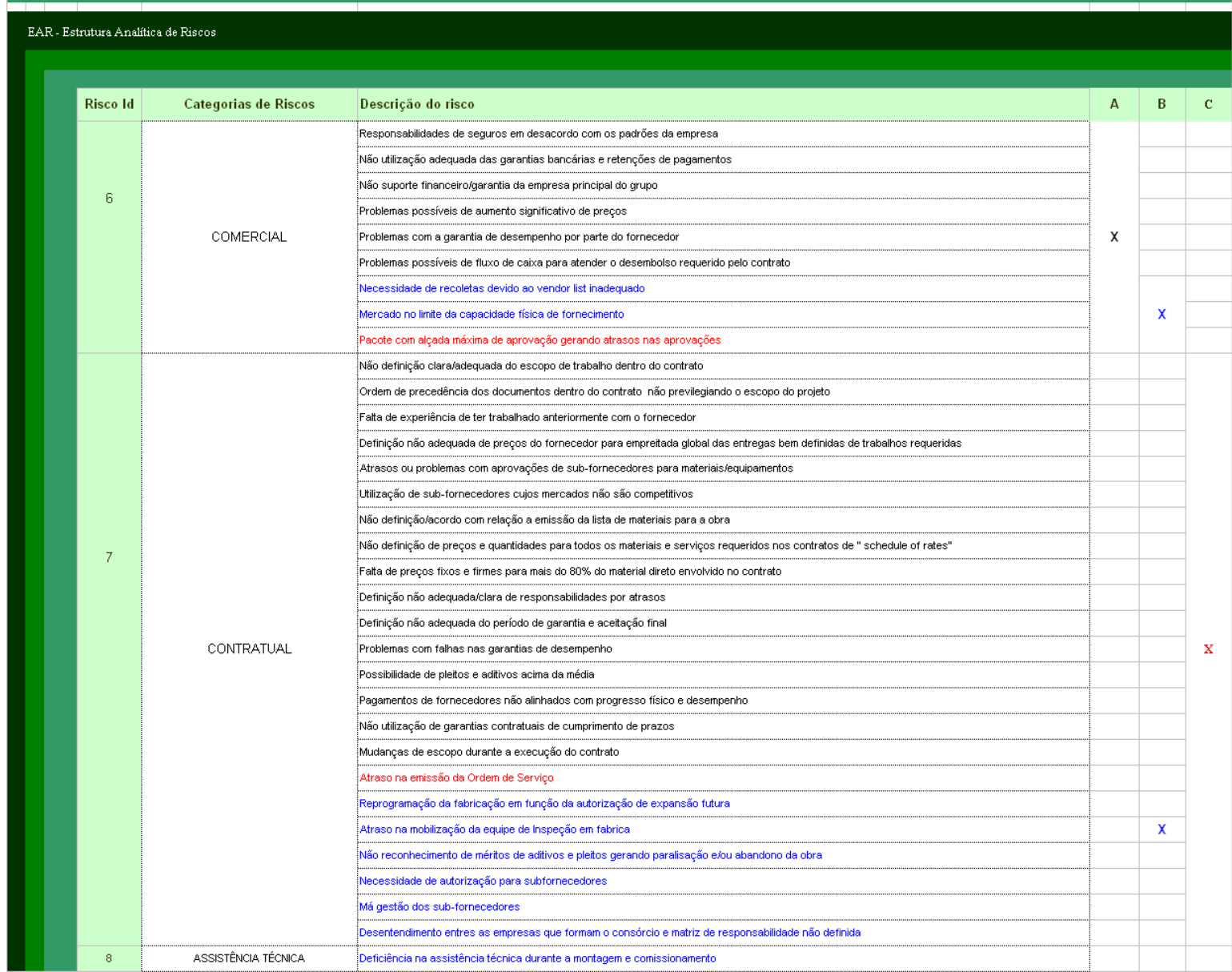

Fonte - Adaptada dos casos A, B e C

Utilizando-se as informações da tabela 23 e considerando como categorias e riscos mais relevantes aqueles que tenham recebido no mínimo 2 indicações, verifica-se nos casos pesquisados que para contratos as categorias de riscos mais relevantes seriam: técnicos e contratual.

Os riscos mais relevantes para a categoria de riscos técnicos identificados seriam:

- Emissão das requisições técnicas com informações inconsistentes ou incompletas;

- Complementação e/ou alteração de escopo durante a fase de contratação;

- Atrasos na emissão de parecer técnico no processo de aquisição;

- Atrasos na emissão da requisição técnica; 
- Atrasos na emissão e análise dos desenhos dos fornecedores.

e para a categoria de riscos contratuais:

- Atraso na mobilização geral das equipes.

$\mathrm{Na}$ avaliação das estruturas analíticas da tabela 24 verifica-se que para suprimentos as categorias de riscos mais relevantes seriam: técnicos, comercial e contratual, sendo os riscos mais relevantes para a categoria de riscos técnicos:

- Desenho dos fornecedores incompatíveis com o projeto básico;

- Erros nos cálculos estruturais;

- Emissão das requisições técnicas com informações inconsistentes ou incompletas;

- Complementação e/ou alteração de escopo durante a fase de contratação;

- Atrasos na emissão da requisição técnica.

Para a categoria de riscos comercial:

- Não adequação da lista de proponentes;

- Mercado no limite da capacidade física de fornecimento;

- Atrasos nas aprovações do processo de aquisição.

E para a categoria de riscos contratual:

○ Atrasos na mobilização da equipe de inspeção em fábrica.

Observa-se que alguns dos riscos identificados nos estudos de caso, também são mencionados na teoria indicando haver alguma aderência da prática à teoria, entretando percebe-se que como a avaliação da relevância das categorias e dos riscos pode ser influenciada por alguns fatores tais como o tipo de contratação, do grau de tecnologia e novidade envolvidas na aquisição, da localização da obra, da situação do mercado e objetivos dos projetos, fica difícil definir uma padronização para a relevância dos riscos.

De forma geral percebe-se também que nos casos estudados e na revisão teórica não existe um consenso para a nomenclatura das categorias de riscos das 
aquisições, dificultando muitas vezes o entendimento dos riscos e comparações. Desta forma o autor descreve no apêndice B deste trabalho uma sugestão de nomenclatura e significado para categorias de riscos das aquisições, utilizando-se como base os riscos descritos pelas empresas pesquisadas e os riscos indicados nas referências teóricas.

\subsection{Lições Aprendidas}

A análise crítica das lições aprendidas mencionadas por cada empresa nos estudos de casos e resumida na tabela 25, sugere atenção aos itens mencionados, reforçando principalmente a importância da necessidade de um sistema de suporte para acompanhamento e atualização dos riscos do projeto e das aquisições e a importância da maturidade das equipes envolvidas e das empresas no gerenciamento de projetos os quais foram mencionados por mais de uma empresa como lições aprendidas.

Tabela 25 - Resumo das lições aprendidas

\begin{tabular}{|l|c|c|c|}
\hline Liçöes Aprendidas & Empresa A & Empresa B & Empresa C \\
\hline Comprometimento de todos os envolvidos & $\mathrm{X}$ & & \\
\hline Suporte dos níveis gerenciais da empresa & $\mathrm{X}$ & & \\
\hline Sistema de suporte para acompanhamento e atualização dos riscos & $\mathrm{X}$ & $\mathrm{X}$ & $\mathrm{X}$ \\
\hline Importância da maturidade no gerenciamento de projetos & & $\mathrm{X}$ & $\mathrm{X}$ \\
\hline Integração do processos de riscos de aquisiçốes com outras disciplinas & & $\mathrm{X}$ & \\
\hline Inclusăo de respostas típicas na EAR & & & $\mathrm{X}$ \\
\hline Envolvimento o mais cedo possivel do gerente de projetos & & & $\mathrm{X}$ \\
\hline Envolvimento da área de aquisiçôes da empresa & & $\mathrm{X}$ \\
\hline
\end{tabular}

Fonte - Adaptada dos casos A, B e C

As lições aprendidas poderiam indicar a não utilização da forma adequada dos itens descritos acima ou que eles tenham sido muito relevantes para o desempenho dos projetos. Para os casos estudados quando não houve efetivamente a utilização adequada das práticas acima houve algum tipo de comprometimento do desempenho dos projetos.

\subsection{Práticas Complementares}

A avaliação das práticas complementares destacadas pelas empresas estudadas no objeto de estudo e resumidas na tabela 26 , sugere que existam outras iniciativas no ambiente empresarial no sentido de adaptar e aperfeiçoar ferramentas e técnicas descritas na teoria para as necessidades das empresas. 
Tabela 26 - Resumo das práticas complementares

\begin{tabular}{|c|c|c|c|}
\hline Práticas Complementares & Empresa A & Empresa B & Empresa C \\
\hline Inclusẫo dos riscos envolvidos nas aquisiçốes nos relatórios de recomendaçẫo de compra & $\mathrm{x}$ & & \\
\hline Sistema de registro de toda documentaçẫo e eventos dos processos de aquisição & $\mathrm{X}$ & & \\
\hline Auditorias corporativas do projeto e aquisições & $\mathrm{X}$ & & $\mathrm{X}$ \\
\hline Matriz de criticidade dos pacotes de aquisiçôes & & $x$ & \\
\hline Detalhamento de engenharia e as técnicas do FEED para licitação & & & $\mathrm{x}$ \\
\hline Indicador de Desempenho de Riscos (IDR) & & & $\mathrm{X}$ \\
\hline Relatório de Acompanhamento de Projetos com ênfase nos riscos do projeto & & & $\mathrm{x}$ \\
\hline
\end{tabular}

Fonte - Adaptada dos casos A, B e C

Percebe-se que algumas das práticas complementares sendo utilizadas, como por exemplo as auditorias corporativas do projeto e aquisições, as inclusões dos riscos envolvidos nas aquisições nos relatórios de recomendação de compra e os indicadores de desempenho de riscos, podem ser instrumentos motivadores da aplicação dos processos de gerenciamento de riscos e portanto podem fortalecer ainda mais a importância do gerenciamento de riscos nas empresas. 


\section{CONCLUSÕES}

\subsection{Conclusão}

Os resultados alcançados com esta pesquisa atenderam plenamente as questões chave definidas como objetivo do trabalho. A pesquisa elucidou a teoria sobre o gerenciamento de projetos, aquisições e gerenciamento de riscos através da revisão e análise conceitual. Através do instrumento de pesquisa e sua aplicação em três casos diferentes pôde-se fazer comparações e identificar algumas evidências para responder as questões chave objeto desta pesquisa.

O estudo mostrou inicialmente que as empresas pesquisadas de relevante atuação no contexto de projetos de bens de capital, valorizam o gerenciamento de riscos aplicado na aquisição de bens e serviços para o sucesso dos seus projetos de bens de capital.

A estruturação do gerenciamento de riscos para as aquisições foi apresentada em detalhes através das estruturas organizacionais geral e especifíca das equipes de projetos, aquisições e de riscos e do detalhamento dos processos de gerenciamento de riscos de cada empresa.

De forma geral o estudo explorou a diversidade dos estudos de casos os quais estão estruturados dentro de realidades diferentes, com estruturas organizações de aquisições diferenciadas (centralizadas, descentralizadas e mistas) e com níveis diferentes de maturidade em gerenciamento de projetos. Percebeu-se que em todas as empresas existem iniciativas de centralização das melhores práticas de gerenciamento de projetos, existência e utilização dos procedimentos de gerenciamento de riscos de projetos, capacitação em gerenciamento de riscos das equipes envolvidas nos projetos e uma motivação para evoluir nas práticas de gerenciamento de riscos e em especial no gerenciamento de riscos para as aquisições. 
As categorias de riscos foram estudadas em detalhes através da análise da estrutura analítica de riscos das empresas e de suas indicações das categorias e riscos mais relevantes para o sucesso da implantação dos projetos de bens de capital.

O estudo mostrou que a relevância dos riscos pode ser influenciada por alguns fatores tais como o tipo de contratação (serviço, material, equipamento ou sistema), do grau de tecnologia e novidade envolvidas na aquisição, da localização da obra, da situação do mercado e objetivos dos projetos, ficando difícil definir uma padronização para a relevância dos riscos. Além disso a relevância pode variar em função da fase do processo de aquisição. Especificamente para os casos pesquisados as categorias de riscos técnicos, comerciais e contratuais foram os indicados como mais relevantes, destacando-se os seguintes riscos comuns para contratos e suprimentos:

Categoria de riscos técnicos:

- Atrasos na emissão da requisição técnica;

- Emissão das requisições técnicas com informações inconsistentes ou incompletas;

- Complementação e/ou alteração de escopo durante a fase de contratação.

Categoria de riscos contratuais:

- Atraso na mobilização geral das equipes.

Categoria de riscos comercial:

- Não adequação da lista de proponentes;

- Mercado no limite da capacidade física de fornecimento;

- Atrasos nas aprovações do processo de aquisição.

O estudo mostrou também que não há consenso com relação a nomenclatura para as categorias de riscos podendo dificultar muitas vezes o entendimento dos riscos e a utilização e ou adequação de uma estrutura analítica de riscos típica para vários projetos. O autor sugeriu no apêndice B uma categorização e descrição com 
exemplos para os riscos de aquisição, baseado nas referências teóricas e casos estudados.

A aderência entre as práticas aplicadas nas empresas e aquelas definidas na teoria foi avaliada através da elaboração do instrumento de pesquisa com conceitos teóricos e a verificação da sua adequação as práticas das empresas.

De forma geral o estudo mostrou que a aderência das práticas dos casos estudados comparados a teoria é limitida, chamando a atenção a baixa aderência dos processos de análise quantitativa dos riscos e do monitoramento e controle.

A identificação da consolidação das práticas relacionadas ao gerenciamento de riscos das aquisições de bens e serviços foi avaliada comparando-se o posicionamento das empresas pesquisadas com relação aos conceitos teóricos, as lições aprendidas e práticas complementares.

O estudo mostrou que as principais práticas que parecem já estar consolidadas nas empresas de relevante atuação no contexto de projetos de bens de capital são:

- Existência de procedimentos corporativos de gerenciamento de riscos de projetos;

- Existência de um departamento ou área responsável por desenvolver e ou manter as melhores práticas de gerenciamento de projetos;

- Utilização de facilitadores no processo de gerenciamento de riscos;

- Definição e utilização da matriz qualitativa de probabilidade $\mathrm{x}$ impacto dos riscos.

O estudo também mostrou que algumas práticas parecem não estar ainda consolidadas no processo de gerenciamento de riscos das aquisições, as quais estão listadas abaixo:

- Análise de oportunidades;

- Definição de tolerância a riscos das partes interessadas;

- Categorização de riscos com baixa qualidade de informações;

- Análise quantitativa de riscos; 
- Respostas para as oportunidades;

- Acompanhamento da eficiência das respostas aos riscos;

- Controle dos impactos das mudanças dos projetos nos riscos;

- Utilização de um sistema de suporte para acompanhamento e atualização dos riscos dos projetos e das aquisições.

O estudo identificou práticas complementares destacadas pelas empresas estudadas no objeto de estudo o que sugere que existam outras iniciativas no ambiente empresarial no sentido de adaptar e aperfeiçoar ferramentas e técnicas descritas na teoria para as necessidades das empresas.

Dentre estas práticas mencionadas destacam-se especificamente para o processo de gerenciamento de riscos das aquisições as listadas abaixo:

- A inclusão dos riscos envolvidos nas aquisições nos relatórios de recomendação de compra;

- Matriz de criticidade dos pacotes de aquisições;

- Auditorias corporativas do projeto e aquisições;

- Indicadores de desempenho de riscos.

As práticas de gerenciamento de projetos têm sido reconhecidas pelas organizações segundo Kerzner (2003) devido a sua capacidade de agregar valor na realização de seus objetivos de negócios.

Os casos estudados indicaram a preocupação das empresas em aplicar as melhores práticas de gerenciamento de projetos, incluindo riscos.

As aquisições para os projetos de bens de capital (IPA, 2004) tem um papel relevante nos resultados dos projetos. Neste sentido a abordagem sistêmica do gerenciamento dos riscos das aquisições pode contribuir com um melhor desempenho dos projetos. 


\subsection{Limitações do estudo}

Os estudos realizados trazem limitações que devem ser consideradas para ponderação dos resultados encontrados. Por se tratar de uma pesquisa qualitativa e tendo a limitação definida na seleção das empresas, o estudo se limitou a três casos, que embora bastante expressivos no universo pesquisado, não permitem conclusões definitivas, mesmo dentro deste universo.

A abordagem dos casos estudados teve a premissa de buscar empresas de grande porte com uma carteira de projetos de bens de capital relevante, portanto limitando a aplicabilidade dos resultados a este tipo de empresas. A aplicação dos resultados e conclusões a nível internacional da pesquisa, também tem as suas limitações tendo em vista que a pesquisa estudou apenas uma empresa internacional.

A seleção das empresas também considerou a opção de utilização de empresas com tipos de organização de aquisição diferentes (centralizada, descentralizada e mista) enriquecendo a análise, porém limitando a comparação dos resultados entre empresas com o mesmo tipo de organização de aquisições.

Destaca-se também que os processos e as práticas analisados nas empresas, envolvem vários aspectos subjetivos, que muitas vezes fogem da sensibilidade dos instrumentos utilizados nas pesquisas.

Finalmente, os resultados alcançados com a pesquisa, absolutamente não esgotam todos os conhecimentos dos processos de gerenciamento de riscos aplicado nas aquisições dos projetos de bens de capital, senão é um incentivo para outros estudos mais profundos sobre o tema.

\subsection{Recomendações para estudos futuros}

O objeto de pesquisa apresenta uma abordagem focada do tema gerenciamento de riscos com sua aplicação nas aquisições de bens e serviços e para os projetos de bens de capital. Entretanto o tema tem as suas derivações e pode ser melhor estudado e detalhado para outros assuntos os quais se mostraram bastantes relevantes durante o desenvolvimento desta pesquisa.

Dentre outros temas de possível interesse e relevância destaca-se a análise crítica das estruturas organizacionais de aquisições e seus impactos na execução dos 
projetos de bens de capital, de maneira a orientar as organizações e os gestores dos projetos das vantagens e desvantagens de cada tipo de organização e os possíveis riscos ou oportunidades nos resultados dos projetos.

Para que as organizações possam iniciar as suas avaliações de riscos de aquisições partindo de algo mais estruturado, é importante a elaboração de estudos mais detalhados e recomendações de uma estrutura analítica de riscos para as aquisições incluindo as respostas típicas para os riscos mapeados.

O estudo mostra que de forma geral as empresas não usam os métodos quantitativos no gerenciamento de riscos das aquisições ou têm dificuldades em sua utilização, desta forma caberia o detalhamento da aplicação e resultados de métodos quantitativos na análise de riscos dos projetos e das aquisições.

Nas estratégias de contratação, as organizações contratantes buscam uma maneira mais eficaz de alocação dos riscos entre contratante e contratado, algumas vezes com bastantes dificuldades e pouca visibilidade dos resultados de uma alocação de riscos não adequada. O estudo detalhado da alocação de riscos em contratos e seus impactos no desempenho dos serviços contratados podem contribuir para melhores alocações de riscos entre contratante e contratado.

Um item ainda muito pouco explorado nas organizações de forma sistemática tem sido a identificação e análise de oportunidades no processo de gerenciamento de riscos, portanto seria bastante valioso o detalhamento e recomendações de ferramentas para a identificação e análise de oportunidades no gerenciamento de riscos.

Nas lições aprendidas deste objeto de pesquisa, as empresas mencionaram as suas dificuldades encontradas no monitoramento e controle dos riscos e também a importância da utilização de sistemas de suporte, desta forma sugere-se a avaliação e recomendação de indicadores de desempenho de riscos para suportar o monitoramento e controle dos riscos e a avaliação e análise crítica de sistemas existentes no mercado que fazem o acompanhamento e controle dos riscos. 


\section{REFERÊNCIAS}

ALMEIDA, K. ; ANDRADE, B.L.R. Análise da aplicação dos conceitos do PMBOK na metodologia de gestão de projetos baseada no IPA para os projetos do setor de petróleo. In: Congresso Brasileiro de Gerenciamento de Projetos, 1. , 2006, Florianópolis.

AS/NZS 4360 - Norma Australiana e da Nova Zelândia de Gerenciamento de Riscos, 2004

ASSOCIATION FOR PROJECT MANAGEMENT - APM. APM Body of Knowledge. Disponível em www.apm.org.uk. Acesso em: 2 maio 2007

AVELLAR, A.P. Analise Preliminar do Setor de Bens de Capital. [São Paulo]: FINEP, 2004. 20 p.

CAGNO, E; CARON, F.; MANCINI, M. A Multi-dimensional Analysis of Major Risks in Complex Projects: Palgrave-journals: Risk Management, Volume 9, issue 1, 2007. Disponível em: < http://www.palgrave-

journals.com/rm/journal/v9/n1/pdf/8250014a.pdf>. Acesso em: 03 agosto 2007

CERVO, A.L.; BERVIAN, P.A. Metodologia Científica: 3 Edição São Paulo, McGraw-Hill do Brasil, 1983.

CLELAND; IRELAND. Gerência de Projetos. Rio de Janeiro: Reichmann \& Affonso, 2002

CIDB - CONSTRUCTION INDUSTRY DEVELOPMENT BOARD. Best Practice Guideline A5: Managing construction procurement risks. South Africa. March, 2004: Edition 1of CIDB document 1005

CONSTRUCTION RISKS. Construction industry risks and exposures. Disponível em: <http://www.C-Risks.com >. Acesso em: 10 junho 2007.

CONROW, E. H. Effective Risk Management: Some Keys to Success. 2nd ed, American Institute of Aeronautics and Astronautics, RESTON, VA, 2003

DALE, F. C. Project Risk Management Guidelines: Managing Risk in Large

Projects and Complex Procurements, 2004 
DOD/DEFENSE ACQUISITIONS UNIVERSITY. Risk Management Guide for DoD Acquisitions. 5th ed. Washington, DC: June 2003

ECO, U. Como se faz uma tese. 16 Edição São Paulo: Perspectiva, 2002

FERMA - FEDERATION OF EUROPEAN RISK MANAGEMENT ASSOCIATIONS. Norma de Gestão de Riscos. AIRMIC, ALARM, IRM: 2002, translation copyright FERMA: 2003.

FERRARI, O. Aquisições, Contratações e Suprimentos em Projetos: Um modelo para avaliação das práticas de gestão. Dissertação (Mestrado) Escola Politécnica Universidade de São Paulo, São Paulo, 2006.

FIDIC - INTERNATIONAL FEDERATION OF CONSULTING ENGINEERS. MDB Harmonised Conditions of Contract for Construction (for Building and Engineering Works). March 2006

GIL, A.C. Como elaborar projetos de pesquisa. São Paulo: Editora Atlas, 1998

HANDFIELD, R. Supply Chain Management. Best Practices in Purchasing and Supply Chain Management - CAPS Research, Volume 1, issue 1, 1997. Disponível em: <http://www.capsresearch.org/research.htm>. Acesso em: 10 maio 2007

HENRIE, M.; HEDGEPETH, O. Project Management Supply Chain Challenges Project Management Practice Magazine (IPMA) - Issue 8, 2006

HILLSON, D. Using a Risk Breakdown Structure in project management - \# Henry Stewart Publications 1472-5967 Journal of Facilities Management Vol .2 NO.1 PP 85-97

HILLSON, D. When is a risk not a risk? Project Manager Today Magazine January 2007

HILLSON, D.; GRIMALDI, S.; RAFELE, C. Managing Project Risks Using a Cross Risk Breakdown Matrix, 2006

HOLLMANN, J.K.; MERROW, E.W. Controlling Project Costs. Chemical Engineering Magazine, 2001. Disponível em: <http://www.che.com >. Acesso em: 2 junho 2007 
HOPKINSON, M. ; LOVELOCK, G. The Project Risk Maturity Model. Assessment of the U.K. MoD's Top 30 Acquisition Projects [conference paper]. Proceedings of the PMI Global Congress 2004-Europe.

INSTITUTE FOR SUPPLY MANAGEMENT; ARIZONA STATE UNIVERSITY. CAPS: Center for Strategic Supply Research - Supply Management Performance Benchmarking Report, 2005

INTERNATIONAL PROJECT MANAGEMENT ASSOCIATION - IPMA. Disponível em: <http://www.ipma.ch >. Acesso em: 10 junho 2007.

IPA - INDEPENDENT PROJECT ANALYSIS. Research and Metrics Measuring Capital Projects Best Practices , 2004. Disponível em:

<http://www.nwccc.org/presents/tapia.pdf >. Acesso em: 5 junho 2007.

KERZNER, H. A Systems Approach to Planning, Scheduling and Controlling. 8th Edition, John Wiley \& Sons, 2003

KERZNER, H. Advanced Project Management: Best Practices on Implementation. 2nd Edition, John Wiley \& Sons, 2004

KNIGHT, K.W. International Risk Management Lexicon. International Federation of Risk and Insurance Management Associations (IFRIMA), 1994

KOVÁCS, A. Enhancing Procurement Practices: Comprehensive Approach to Acquiring Complex Facilities and Projects, 2004

LOOSEMORE, A. N. M. Risk allocation in the private provision of public infrastructure. International Journal of Project Management 25 (2007) 66-76

MABERT, V. A. The Design of a Supplier Alliance Program. Best Practices in Purchasing and Supply Chain Management - CAPS Research, Volume 1, issue 1,1997. Disponível em: <http://www.capsresearch.org/research.htm>. Acesso em: 10 junho 2007

MARTINS, V.A. Conceitos de Outsourcing aplicados à operação de escritório de gerenciamento de projetos. 2007. 172 p. Dissertação (Mestrado) - Escola Politécnica, Universidade de São Paulo, São Paulo, 2007. 
MERROW, E.W. Megafield Developments require special tatics, risk management - IPA, 2003. Disponível em:

$<$ http://www.ipainstitute.com/home/publications/pdf/ipa_megafield_developments.pdf >. Acesso em: 8 junho 2007.

MERROW, E.W. The Cost of Project Risks: Contracting for Large International Projects in the New Era; SPE Cairo Section May 22, 2006

NAGALI, V. Procurement Risk Management (PRM) at Hewlett-Packard Company - Council of Supply Chain Management Professionals

NUMMELIN, J. Uncertainty Management Concerning Cultural Dynamics in Project Management - Case Study. Annual Publication of International Project Management Association, Vol. XXVIII, ISSN 1455-4178, 2006.

PSC - PROCUREMENT STRATEGY COUNCIL. Reputation Risk-Assessment Model. Disponível em: <http://www.hoovers.com >. Acesso em: 10 junho 2007.

PSC - PROCUREMENT STRATEGY COUNCIL. Structuring Contracts to Reduce Risk. 2003. Disponível em: <http://www.pscexecutiveboard.com >. Acesso em: 10 junho 2007

PROJECT MANAGEMENT INSTITUTE. Four Campus Boulevard, Newton Square, PA 19073-3299 EUA - Construction Extension Book. 1st Edition C2002

PROJECT MANAGEMENT INSTITUTE. Four Campus Boulevard, Newton Square, PA 19073-3299 EUA - Um Guia do Conjunto de Conhecimentos em Gerenciamento de Projetos (Guia PMBOK®) Terceira Edição @2004

PROTIVITI - INDEPENDENT RISK CONSULTING. How to manage supply and procurement risks and increase profits. 2007. Disponível em:

<http://www.protiviti.com >. Acesso em: 10 junho 2007

RAZ, T. ; HILLSON, D. A Comparative Review of Risk Management Standards. Risk Management: An International Journal 2005, 7 (4), 53-66

REGEV, S.; SHTUB, A.;BEN-HAIM, Y. Managing Project Risks as Knowledge Gaps. Project Management Journal. V37, number 5 Edition December 2006

ROVAI, R.L. Modelo estruturado para a gestão de riscos em projetos: estudo de múltiplos casos. 2005. 375 p. Tese (Doutorado) - Escola Politécnica, Universidade de São Paulo, São Paulo, 2005. 
SCHEUING, E. Reinventing Purchasing for Competitive Advantage. Best Practices in Purchasing and Supply Chain Management - CAPS Research, Volume 1, issue 1, 1997. Disponível em: <http://www.capsresearch.org/research.htm>. Acesso em: 5 junho 2007

SKELTON, T.M.; THAMHAIN, H. J. Managing Risk in New Product Development Projects: Beyond Analytical Methods. Annual Publication of International Project Management Association, Vol. XXVIII, ISSN 1455-4178,2006.

SILVA, C.R.O. Diretrizes para elaboração de projetos de pesquisa, monografias, dissertações e teses,2006

Disponível em: < http://vicenterisi.googlepages.com/Metodologiatrab.cientifico-

CROSilvaV.pdf >. Acesso em: 5 junho 2007.

SILVA, E. L. Metodologia da Pesquisa e Elaboração da Dissertação: 3 edição Florianópolis - Laboratório de Ensino à Distância da UFSC, 2001.

SILVA, W.G.R. Metodologia de Gerenciamento de Projetos do Segmento de E\&P da Petrobrás. In: SEMINÁRIO INTERNACIONAL DO PMI-SP. 2003

TORRE M. “Unknown Knowns” Outlines of an effective knowledge management. Annual Publication of International Project Management Association, Vol. XXVIII, ISSN 1455-4178, 2006.

UNIVERSIDADE DE SÃO PAULO: ESCOLA POLITÉCNICA/ DIVISÃO DE BIBLIOTECA. Diretrizes para a Apresentação de Dissertações e Teses / Divisão de Biblioteca da Epusp - 3 edição, São Paulo, 2006

ZSIDISIN, G. Measuring Supply Risks: An example from Europe. Best Practices in Purchasing and Supply Chain Management - CAPS Research, Volume 4, issue 3, 2001. Disponível em: <http://www.capsresearch.org/research.htm>. Acesso em: 5 maio 2007

WIDEMAN, R. M. Managing the Development of Building Projects for Better Results. First published in 1981, AEW Services, Vancouver, BC, (c December 2000 
APÊNDICE A - Questionário de Apoio à Pesquisa 


\section{UNIVERSIDADE DE SÃO PAULO ESCOLA POLITÉCNICA \\ DEPARTAMENTO DE ENGENHARIA NAVAL \\ MESTRADO \\ ÊNFASE EM GESTÃO DE PROJETOS}

\section{QUESTIONÁRIO DE APOIO À PESQUISA}

O objetivo deste questionário é o obter um melhor entendimento sobre as práticas atuais do gerenciamento de riscos aplicadas nas aquisições de projetos de bens de capital.

As informações obtidas através deste questionário destinam-se a pesquisa acadêmica e terão sua origem mantida confidencial.

\section{CARACTERIZAÇÃO DA EMPRESA}

\begin{tabular}{|l|}
\hline Razão Social: \\
\hline Nome Fantasia: \\
\hline Pais de Origem: \\
\hline Setor: \\
\hline Principal Segmento de Negócios: \\
\hline Tipo de Capital (aberto ou fechado): \\
\hline Número de Funcionários: \\
\hline Faturamento Anual (US\$): \\
\hline Carteira de Projetos Atual (US\$): \\
\hline Valor Médio dos Projetos (US\$): \\
\hline Duração típica dos Projetos: \\
\hline Número Médio de Projetos na carteira anual: \\
\hline Tipo de Organização de Aquisições (Centralizada, Descentralizada, Mista): \\
\hline
\end{tabular}




\section{QUALIFICAÇÃO DO ENTREVISTADO}

\begin{tabular}{|l|}
\hline Nome: \\
\hline Função: \\
\hline Tempo de Atuação Profissional: \\
\hline Tempo de Empresa: \\
\hline Tempo na Função: \\
\hline Área ou Departamento: \\
\hline
\end{tabular}

\section{CONTEXTO E IMPORTÂNCIA DO GERENCIAMENTO DE RISCOS APLICADO NAS AQUISIÇÕES DE PROJETOS DE BENS DE CAPITAL}

Considerar quando necessário o período dos últimos 3 anos para as afirmativas propostas. Considerar uma escala gradual de concordância das afirmativas propostas, conforme o critério abaixo:

1 Discordo Totalmente

2 Discordo

3 Neutro

4 Concordo

5 Concordo Totalmente

\begin{tabular}{|c|l|l|l|l|l|l|}
\hline ITEM & \multicolumn{1}{|c|}{ AFIRMATIVA } & $\mathbf{1}$ & $\mathbf{2}$ & $\mathbf{3}$ & $\mathbf{4}$ & $\mathbf{5}$ \\
\hline 3.1 & $\begin{array}{l}\text { Existem procedimentos corporativos de } \\
\text { gerenciamento de riscos de projetos na empresa? }\end{array}$ & & & & & \\
\hline 3.2 & $\begin{array}{l}\text { As equipes de projetos são treinadas no processo de } \\
\text { gerenciamento de projetos e especialmente em } \\
\text { riscos? }\end{array}$ & $\begin{array}{l}\text { A empresa possui um departamento ou área } \\
\text { responsável por desenvolver e ou manter as melhores } \\
\text { práticas de gerenciamento de projetos? }\end{array}$ & & & & \\
\hline 3.4 & $\begin{array}{l}\text { Há reconhecimento da alta administração da empresa } \\
\text { da importância estratégica da área de aquisições para }\end{array}$ & & & & & \\
\hline
\end{tabular}




\begin{tabular}{|c|l|l|l|l|l|}
\hline & a competitividade e sobrevivência da empresa? & & & \\
\hline 3.5 & $\begin{array}{l}\text { A empresa conta com procedimentos corporativos de } \\
\text { gerenciamento das aquisições? }\end{array}$ & & & & \\
\hline 3.6 & $\begin{array}{l}\text { A empresa utiliza métricas de prazos, custos e } \\
\text { qualidade para avaliar os processos de gerenciamento } \\
\text { das aquisições? }\end{array}$ & $\begin{array}{l}\text { O planejamento e as estratégias das aquisições levam } \\
\text { em consideração os riscos gerais do projeto e aqueles } \\
\text { específicos dos processos de aquisições? }\end{array}$ & & & \\
\hline 3.7 & & & \\
\hline
\end{tabular}

\section{PRÁTICAS OPERACIONAIS NA EMPRESA}

Considerar quando necessário o período dos últimos 3 anos para as afirmativas propostas. Considerar uma escala gradual de concordância das afirmativas propostas, conforme o critério abaixo:

1 Discordo Totalmente

2 Discordo

3 Neutro

4 Concordo

5 Concordo Totalmente

\subsection{Planejamento do Gerenciamento de Riscos}

\begin{tabular}{|c|c|c|c|c|c|}
\hline ITEM & AFIRMATIVA & 1 & 2 & 3 & 4 \\
\hline 4.1.1 & $\begin{array}{l}\text { A empresa possui processo estabelecido específico } \\
\text { para o gerenciamento de riscos em aquisições dos } \\
\text { projetos? }\end{array}$ & & & & \\
\hline 4.1.2 & $\begin{array}{l}\text { As atribuições de funções e responsabilidades estão } \\
\text { bem definidas para as atividades de gerenciamento de } \\
\text { riscos das aquisições? }\end{array}$ & & & & \\
\hline 4.1.3 & $\begin{array}{l}\text { Existe provisão para atividades de gerenciamento de } \\
\text { riscos das aquisições no orçamento e no cronograma } \\
\text { dos projetos? }\end{array}$ & & & & \\
\hline 4.1 .4 & As categorias de riscos específicas para o processo & & & & \\
\hline
\end{tabular}




\begin{tabular}{|l|l|l|l|l|l|}
\hline & $\begin{array}{l}\text { de gerenciamento de riscos das aquisições dos } \\
\text { projetos estão bem definidas? }\end{array}$ & & & & \\
\hline 4.1 .5 & $\begin{array}{l}\text { O processo de gerenciamento de riscos em aquisições } \\
\text { está alinhado com os objetivos dos projetos? }\end{array}$ & & & & \\
\hline 4.1 .6 & $\begin{array}{l}\text { Os interessados do projeto são envolvidos no } \\
\text { processo de gerenciamento de riscos das aquisições } \\
\text { dos projetos? }\end{array}$ & $\begin{array}{l}\text { As equipes multidisciplinares que participam do } \\
\text { processo de gerenciamento de riscos das aquisições } \\
\text { dos projetos são previamente treinadas na } \\
\text { metodologia de riscos? }\end{array}$ & & & \\
\hline 4.1 .8 & $\begin{array}{l}\text { Existem facilitadores para a condução do processo de } \\
\text { gerenciamento de riscos das aquisições? }\end{array}$ & & & & \\
\hline
\end{tabular}

\subsubsection{Qual a estrutura organizacional típica para aplicação e acompanhamento do plano de gerenciamento de riscos das aquisições na empresa?}




\subsection{Identificação dos Riscos}

\begin{tabular}{|c|l|l|l|l|l|l|}
\hline ITEM & \multicolumn{1}{|c|}{ AFIRMATIVA } & $\mathbf{1}$ & $\mathbf{2}$ & $\mathbf{3}$ & $\mathbf{4}$ & $\mathbf{5}$ \\
\hline 4.2 .1 & $\begin{array}{l}\text { São considerados os riscos envolvidos em todas as } \\
\text { etapas do processo de aquisição, incluindo desde a } \\
\text { elaboração e aprovação da Requisição de Compra, } \\
\text { processo de contratação, gestão e encerramento do } \\
\text { contrato? }\end{array}$ & & & & & \\
\hline 4.2 .2 & $\begin{array}{l}\text { A incerteza nas premissas do projeto com impacto nas } \\
\text { aquisições dos projetos são avaliadas? }\end{array}$ & & & & \\
\hline 4.2 .3 & $\begin{array}{l}\text { As informações publicadas, inclusive bancos de dados } \\
\text { comerciais, estudos acadêmicos, benchmarking, } \\
\text { profissionais experientes, outros estudos do setor são } \\
\text { utilizados para a identificação dos riscos das } \\
\text { aquisições dos projetos? }\end{array}$ & & & & & \\
\hline 4.2 .4 & $\begin{array}{l}\text { Na identificação dos riscos leva-se também em } \\
\text { considerações as oportunidades? }\end{array}$ & & & & \\
\hline
\end{tabular}

\subsubsection{Listar a Estrutura Analítica de Riscos (EAR) típica utilizada pela Empresa para as Aquisições de Bens e Serviços.}




\subsubsection{Listar as 5 categorias de riscos mais relevantes que do ponto de vista da empresa tipicamente impactam mais no processo de gerenciamento das aquisições.}

\subsection{Análise Qualitativa de Riscos}

\begin{tabular}{|c|c|c|c|c|c|c|}
\hline ITEM & AFIRMATIVA & 1 & 2 & 3 & 4 & 5 \\
\hline 4.3 .1 & $\begin{array}{l}\text { Existe uma definição qualitativa clara para a } \\
\text { probabilidade e impacto dos riscos? }\end{array}$ & & & & & \\
\hline 4.3 .2 & $\begin{array}{l}\text { Existe uma definição clara das tolerâncias a risco das } \\
\text { partes interessadas? }\end{array}$ & & & & & \\
\hline 4.3 .3 & $\begin{array}{l}\text { A probabilidade e impacto dos riscos identificados são } \\
\text { avaliados em entrevistas ou reuniões com } \\
\text { participantes selecionados por sua familiaridade com } \\
\text { as categorias de riscos? }\end{array}$ & & & & & \\
\hline 4.3 .4 & $\begin{array}{l}\text { É gerado algum registro de risco no processo de } \\
\text { análise qualitativa, que estabelecem os riscos por } \\
\text { prioridade separadamente para custo, tempo, escopo } \\
\text { e qualidade e/ou por categorias de riscos? }\end{array}$ & & & & & \\
\hline 4.3 .5 & $\begin{array}{l}\text { Existem procedimentos para categorização dos riscos } \\
\text { identificados e qualificados com baixa qualidade? }\end{array}$ & & & & & \\
\hline
\end{tabular}




\subsection{Análise Quantitativa de Riscos}

\begin{tabular}{|c|c|c|c|c|c|c|}
\hline ITEM & AFIRMATIVA & 1 & 2 & 3 & 4 & 5 \\
\hline 4.4 .1 & $\begin{array}{l}\text { É normalmente utilizada a análise quantitativa de } \\
\text { riscos das aquisições para visibilidade numérica dos } \\
\text { desvios de prazos e custos dos projetos? }\end{array}$ & & & & & \\
\hline 4.4 .2 & $\begin{array}{l}\text { Os dados e as técnicas da análise quantitativa de } \\
\text { riscos são avaliados e validados por especialistas no } \\
\text { assunto, internos ou externos à organização? }\end{array}$ & & & & & \\
\hline 4.4 .3 & $\begin{array}{l}\text { É utilizada as ferramentas de análise de sensibilidade } \\
\text { ou análise do valor monetário esperado ou análise da } \\
\text { árvore de decisão no processo de análise quantitativa } \\
\text { de riscos da aquisição? }\end{array}$ & & & & & \\
\hline 4.4 .4 & $\begin{array}{l}\text { A análise quantitativa de riscos é feita novamente } \\
\text { após o plano de respostas aos riscos para avaliar a } \\
\text { nova criticidade dos riscos das aquisições referentes a } \\
\text { prazo e custos e sua adequação a tolerância das } \\
\text { partes interessadas? }\end{array}$ & & & & & \\
\hline 4.4 .5 & $\begin{array}{l}\text { A análise quantitativa de riscos das aquisições } \\
\text { identifica o impacto das incertezas nos objetivos do } \\
\text { projeto (prazo e custo)? }\end{array}$ & & & & & \\
\hline
\end{tabular}




\subsection{Planejamento de Respostas a Riscos}

\begin{tabular}{|c|c|c|c|c|c|c|}
\hline ITEM & AFIRMATIVA & 1 & 2 & 3 & 4 & 5 \\
\hline 4.5 .1 & $\begin{array}{l}\text { As respostas a riscos planejadas são adequadas à } \\
\text { importância do risco, econômicas ao enfrentar o } \\
\text { desafio, rápidas, realistas dentro do contexto do } \\
\text { projeto, acordadas por todas as partes envolvidas, e } \\
\text { de propriedade de uma pessoa específica? }\end{array}$ & & & & & \\
\hline 4.5 .2 & $\begin{array}{l}\text { As estratégias para as respostas às ameaças } \\
\text { normalmente utilizam uma abrangência envolvendo a } \\
\text { prevenção, transferência e mitigação dos riscos? }\end{array}$ & & & & & \\
\hline 4.5 .3 & $\begin{array}{l}\text { As estratégias para as respostas às oportunidades } \\
\text { normalmente utilizam uma abrangência envolvendo a } \\
\text { exploração, compartilhamento e melhorias? }\end{array}$ & & & & & \\
\hline 4.5 .4 & $\begin{array}{l}\text { É utilizado de forma adequada estratégias para } \\
\text { respostas contigenciadas, que normalmente são } \\
\text { executadas quando da ocorrência de eventos pré- } \\
\text { definidos? }\end{array}$ & & & & & \\
\hline 4.5 .5 & $\begin{array}{l}\text { O processo de planejamento de respostas a riscos } \\
\text { depois de concluído é retro alimentado no plano de } \\
\text { aquisições e contratações, ajustando quando } \\
\text { necessário as estratégias de aquisições? }\end{array}$ & & & & & \\
\hline 4.5 .6 & $\begin{array}{l}\text { As estratégias de respostas a riscos acordadas são } \\
\text { fornecidas como realimentação aos processos } \\
\text { adequados de outras áreas de conhecimento, } \\
\text { inclusive ao orçamento e cronograma do projeto? }\end{array}$ & & & & & \\
\hline
\end{tabular}




\subsection{Monitoramento e Controle de Riscos}

\begin{tabular}{|c|c|c|c|c|c|c|}
\hline ITEM & AFIRMATIVA & 1 & 2 & 3 & 4 & 5 \\
\hline 4.6 .1 & $\begin{array}{l}\text { Existem revisões periódicas e ou reavaliações de } \\
\text { riscos das aquisições durante a execução do projeto }\end{array}$ & & & & & \\
\hline 4.6 .2 & $\begin{array}{l}\text { É realizado um acompanhamento periódico da } \\
\text { eficiência das ações de respostas aos riscos das } \\
\text { aquisições }\end{array}$ & & & & & \\
\hline 4.6 .3 & $\begin{array}{l}\text { As mudanças aprovadas no projeto são analisadas em } \\
\text { relação a efeitos no registro de riscos, plano de } \\
\text { respostas a riscos ou plano de gerenciamento de } \\
\text { riscos. }\end{array}$ & & & & & \\
\hline 4.6 .4 & $\begin{array}{l}\text { O registro de riscos das aquisições é atualizado } \\
\text { durante a execução do projeto, para incorporar os } \\
\text { resultados das reavaliações de riscos, auditorias de } \\
\text { riscos ou revisões periódicas de riscos }\end{array}$ & & & & & \\
\hline
\end{tabular}

\section{PROSPECÃO DE PRÁTICAS COMPLEMENTARES E LIÇÕES APRENDIDAS}

5.1 Relacionar resumidamente eventuais práticas complementares utilizadas na empresa para a gestão de riscos das aquisições dos projetos de bens de capital.

5.2 Relacionar resumidamente eventuais lições aprendidas na empresa no processo de gestão de riscos das aquisições dos projetos de bens de capital. 
APÊNDICE B - Definição das Categorias de Riscos 
No intuito de facilitar o entendimento da nomenclatura das categorias de riscos, descreve-se abaixo uma sugestão de nomenclatura com o resumo do significado destas categorias e alguns exemplos de riscos:

Riscos Técnicos: São aqueles riscos típicos relacionados ao nível de detalhamento e qualidade da especificação técnica, os seus requisitos de desempenho, confiabilidade, segurança, critérios gerais de aceitação, definição das interfaces técnicas para a aquisição e riscos de atrasos em atividades técnicas. Alguns exemplos poderiam ser: não entendimento dos códigos e padrões a serem utilizados, especificações não adequadas de tubulações, nível de engenharia inadequado para modalidade de contratação, possibilidade de alteração de escopo.

Riscos Tecnológicos: São aqueles riscos típicos relacionados a complexidade técnica ou de requisitos do objeto que podem gerar dificuldades no processo de aquisição. Alguns exemplos poderiam ser: utilização de tecnologia ainda não provada, utilização de materiais exóticos, exigência de um plano de qualidade assegurada de engenharia e fabricação.

Riscos Ambientais: São aqueles riscos típicos relacionados a exigências regulatórias do meio ambiente e que podem influenciar o processo de aquisição. Alguns exemplos poderiam ser: limitações ecológicas, não identificação clara de todas as fontes de resíduos, restrições de emissão e disposição de resíduos, existência de requisitos ambientais especiais a serem considerados, atrasos de aprovações de licenças

Riscos de Fabricação: São aqueles riscos típicos relacionados a fabricação de equipamentos e ou materiais e que podem comprometer a qualidade, desempenho e prazos de entrega. Alguns exemplos poderiam ser: não existência de um plano de qualidade assegurada de fabricação, atrasos nos fornecimento de matéria prima para fabricação, não entendimento das atividades no caminho crítico de fabricação, dificuldades com interfaces técnicas externas, revisões de documentos de engenharia. 
Riscos de Construção: São aqueles riscos típicos relacionados a construção, envolvendo mobilização de mão de obra, instalação de canteiros e execução de obras civis e que podem comprometer o início da montagem dos equipamentos e materias, prazos de entrega finais da obra e desempenho dos sistemas. Alguns exemplos poderiam ser: não disponibilidade de materiais para construção no prazo requerido, não execução de testes geotécnicos e análise de solos requeridas, atraso na preparação das instalações provisórias, atrasos devidos a não disponibilidade de itens de fornecimento do contratante, dificuldades para o avanço das frentes de trabalho, problemas de interfaces do contratante com o contratado.

Riscos de Inspeção: São aqueles riscos típicos relacionados as deficiências nos processos de definição e execução das inspeções da fabricação de equipamentos e que podem comprometer o desempenho dos equipamentos em operação. Alguns exemplos poderiam ser: não adequação ou existência de um plano de inspeção, relatórios de inspeções não adequados.

Riscos de Fiscalização: São aqueles riscos típicos relacionados as deficiências nos processos de acompanhamento dos serviços de construção e que podem comprometer o acompanhamento físico e os desembolsos financeiros dos contratos. Alguns exemplos poderiam ser: não adequação ou existência de um plano de fiscalização, relatórios de fiscalização não adequados.

Riscos de Logística: São aqueles riscos típicos relacionados a problemas e dificuldades para garantir o embarque, transporte, recebimento e entrega de materiais e equipamentos e condições de acessos para a mobilização e execução da construção. Alguns exemplos poderiam ser: problemas não usuais de manuseio de equipamentos/materiais, problemas com importação de materiais $\mathrm{e}$ equipamentos, problemas com transporte/acesso interno na planta.

Riscos de Armazenagem: São aqueles riscos típicos relacionados a problemas e dificuldades na guarda e localização de materiais e equipamentos para a execução dos projetos. Alguns exemplos poderiam ser: danificação e perda de peças e componentes, dificuldade no rastreamento e localização das peças e componentes, requisitos especiais de armazenamento. 
Riscos de Comissionamento: São aqueles riscos típicos relacionados aos testes com carga dos equipamentos e sistemas, normalmente antes da fase de início de operação assistida e que contribuem no processo para garantir o desempenho contratual requerido nas fases operacionais. Alguns exemplos poderiam ser: definição não adequada dos procedimentos de comissionamento e entrega, definição não adequada dos critérios de aceitação dos testes de desempenho, duração não adequada do período de comissionamento.

Riscos Externos (Regionais) : São aqueles riscos típicos relacionados ao ambiente externo e no qual normalmente tem-se pouco ou nenhum poder de influenciá-los e está ligado muitas vezes a localização do projeto. Alguns exemplos poderiam ser: clima, mudanças na legislação, restrições de exportação / importação, políticos, país, pressão de grupos organizados, força maior.

Riscos Comerciais: São aqueles riscos típicos relacionados ao estabelecimento e cumprimento das cláusulas contratuais, envolvendo normalmente definições de termos e condições contratuais, financiamentos, seguros, garantias, termos de pagamento, suspensão e término, suprimentos interno, subcontratos, leis aplicáveis, parcerias, legislação, regulamentos, taxas de câmbio, fórmulas de reajustes contratuais. Alguns exemplos poderiam ser: responsabilidades de seguros em desacordo com padrões da empresa, não utilização adequada das garantias bancárias e retenções de pagamentos, não suporte financeiro/garantia da empresa principal do grupo, problemas possíveis de fluxo de caixa para atender o desembolso requerido.

Riscos Contratuais: São aqueles riscos típicos relacionados a elaboração,negociação e execução contratual, envolvendo por exemplo não definição clara e adequada do escopo de trabalho dentro do contrato, linguagem contratual vaga e genérica, escopo ou limites de responsabilidades não bem definidos, limites de obrigações, falta de definição de procedimentos de controle de mudanças, incapacidade de cumprir marcos contratuais.

Riscos de Instalação: São aqueles riscos típicos relacionados a instalação ou montagem de equipamentos e ou sistemas, envolvendo mobilização de mão de obra 
e equipamentos para a montagem, instalação de canteiros e execução de montagens eletromecânicas e que podem comprometer o início da montagem dos equipamentos e materias, prazos de entrega finais da obra e desempenho dos sistemas. Alguns exemplos poderiam ser: não disponibilidade de equipamentos e materiais para montagem no prazo requerido, atrasos devidos a não disponibilidade de itens de fornecimento do contratante, dificuldades para o avanço das frentes de trabalho, problemas de interfaces do contratante com o contratado.

Riscos do Mercado: São aqueles riscos típicos relacionados a capacidade e disponibilidade do mercado para a aquisição dos bens ou serviços e que podem comprometer o desempenho da aquisição com relação aos prazos de contratação, preços, tempo de entrega e qualidade do objeto a ser adquirido. Alguns exemplos poderiam ser: aumento da competição, mudanças na demanda, custos e disponibilidade de materiais, limitação de recursos humanos especializados, falta de capacidade / disponibilidade do mercado local para atender as demandas do contrato.

Riscos de Fornecedores: São aqueles riscos típicos relacionados a capacidade e disponibilidade dos fornecedores, bem como ao nível de confiança e relacionamento com o fornecedor. Alguns exemplos poderiam ser: limitação de fornecedores qualificados para participação no processo de contratação, falta de experiência de ter trabalhado anteriormente com o fornecedor.

Riscos de Saúde e Segurança Operacional: São aqueles riscos típicos relacionados as condições requeridas na aquisição para a qualificação dos fornecedores e execução contratual com relação a saúde e segurança operacional, podendo impactar a lista de fornecedores qualificados, preços, prazos e qualidade contratuais. Alguns exemplos poderiam ser: índice mínimo de acidentes sem afastamento, ataque de animais silvestres na equipe mobilizada.

Riscos de Pós Venda: São aqueles riscos típicos relacionados as limitações de atendimento aos serviços e suporte técnico durante o período pós venda. Alguns exemplos poderiam ser: dificuldade de atendimento local, reposição e estoque de materiais e equipamentos. 